\title{
ATRIBUTOS MINERALÓGICOS E ELETROQUÍMICOS, ADSORÇÃO E DESSORÇÃO DE SULFATO EM SOLOS PAULISTAS
}

MARCELO EDUARDO ALVES

Tese apresentada à Escola Superior de Agricultura "Luiz de Queiroz", Universidade de São Paulo, para obtenção do título de Doutor em Agronomia. Área de Concentração: Solos e Nutrição de Plantas.

PIRACICABA

Estado de São Paulo - Brasil

Fevereiro - 2002 


\title{
ATRIBUTOS MINERALÓGICOS E ELETROQUÍMICOS, ADSORÇÃO E DESSORÇÃO DE SULFATO EM SOLOS PAULISTAS
}

\author{
MARCELO EDUARDO ALVES \\ Engenheiro Agrônomo
}

Orientador: Prof. Dr. ARQUIMEDES LAVORENTI

Tese apresentada à Escola Superior de Agricultura "Luiz de Queiroz", Universidade de São Paulo, para obtenção do título de Doutor em Agronomia. Área de Concentração: Solos e Nutrição de Plantas.

PIRACICABA

Estado de São Paulo - Brasil

Fevereiro - 2002 
Dados Internacionais de Catalogação na Publicação (CIP)

DIVISÃO DE BIBLIOTECA E DOCUMENTAÇÃO - ESALQ/USP

\author{
Alves, Marcelo Eduardo \\ Atributos mineralógic os e eletroquímic os, adsorção e dessorção de sulfato \\ em solos paulistas/ Marc elo Eduardo Alves. - - Piracicaba, 2002. \\ 154 p. : il. Acompanha CD-ROM \\ Tese (doutorado) - Escola Superior de Agricultura Luiz de Queiroz, 2002. \\ Bibliografia. \\ 1. Mineralogia do solo 2. Química do solo 3. Troca iônic a I. Título
}

CDD 631.416

\title{
"Permitida a cópia total ou parcial deste documento, desde que citada a fonte - $\mathrm{O}$ autor"
}




\section{AGRADECIMENTOS}

$\checkmark$ A Deus pela vida e oportunidades de aprendizado.

$\checkmark$ Ao Prof. Dr. Arquimedes Lavorenti pela amizade sincera, orientação, incentivo irrestrito e confiança depositada.

$\checkmark$ À Coordenação de Aperfeiçoamento de Pessoal de Nível Superior - CAPES pela concessão inicial da bolsa de estudo e àFundação de Amparo àPesquisa do Estado - FAPESP - pela concessão da bolsa de estudo e pelo auxílio financeiro, sem o qual esse trabalho não se teria concretizado.

$\checkmark$ Ao Prof. Dr. Reinaldo Bertola Cantarutti do Departamento de Solos da Universidade Federal de Viçosa pela amizade e incentivo.

$\checkmark$ Ao Prof. Dr. Donald Lewis Sparks do Departamento de Ciência Vegetal e do Solo da Universidade de Delaware - EUA pela atenciosidade e todo auxílio prestado durante a tentativa de viabilização de treinamento junto ao seu laboratório.

$\checkmark$ Ao Prof. Dr. José Carlos Chitolina pela sincera disposição de sempre ajudar.

$\checkmark$ Ao Prof. Dr. José Carlos Casagrande pela gentil cessão de amostras de solos ácricos.

$\checkmark$ Ao Dr. Hélio do Prado pelo auxílio prestado por ocasião das coletas de amostras de solo.

$\checkmark$ Aos colegas Marcos Gama e Antonio Marchiori pela amizade e pelo auxílio prestado durante as amostragens de solos. 
$\checkmark$ Ao analista de sistemas Carlos Roberto Macedonio pela significativa contribuição prestada a esse trabalho.

$\checkmark$ Ao Prof. Arnaldo Antonio Rodella pelo auxílio com métodos analíticos.

$\checkmark$ À secretária Maria Angélica pela atenciosidade de sempre.

$\checkmark$ Ao técnico Carlos Rubini Júnior pelo imprescindível auxílio nas determinações analíticas.

$\checkmark$ Aos meus familiares pelo apoio e compreensão.

$\checkmark$ Aos colegas do curso de pós-graduação pela amizade e colaboração.

$\checkmark$ A todos que direta ou indiretamente contribuíram para a execução desse trabalho. 


\section{SUMÁRIO}

Página

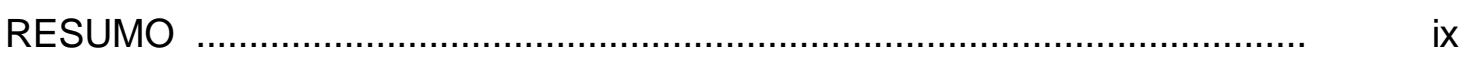

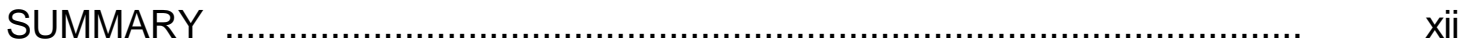

1 INTRODUÇÃO ...............................................................................

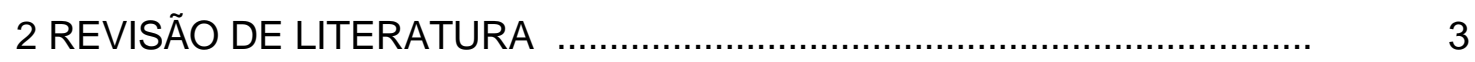

2.1 Mineralogia da fração argila dos solos tropicais ...................................

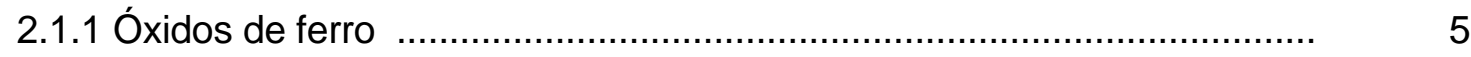

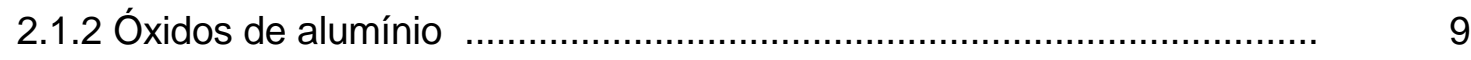

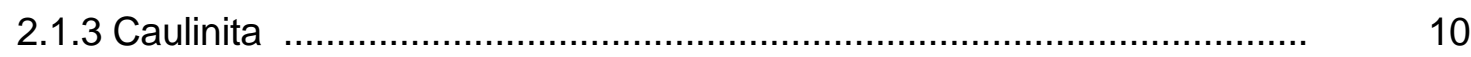

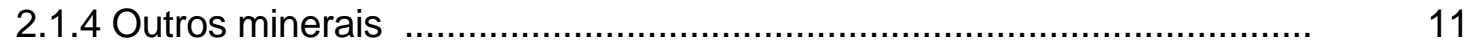

2.2 Ponto de efeito salino nulo ......................................................... 11

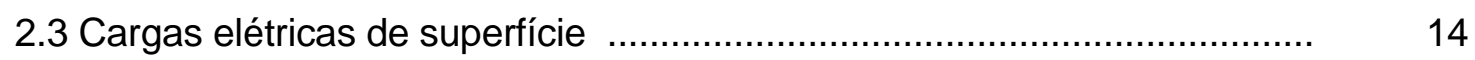

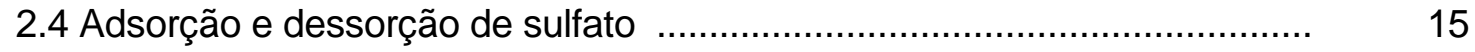

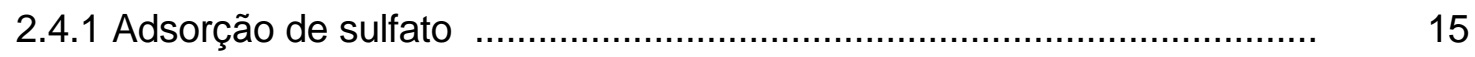

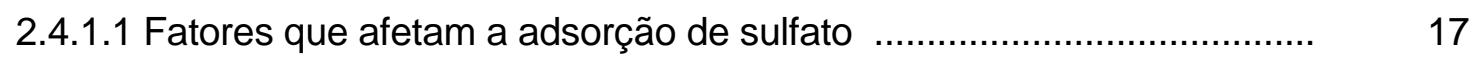

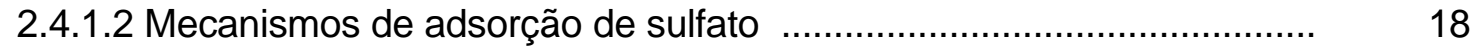

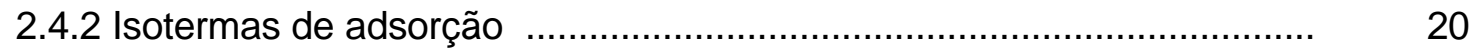

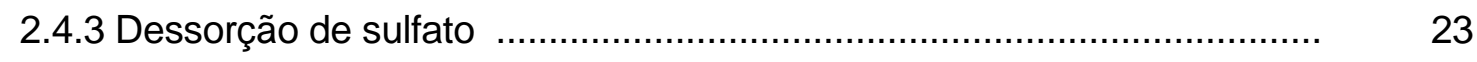

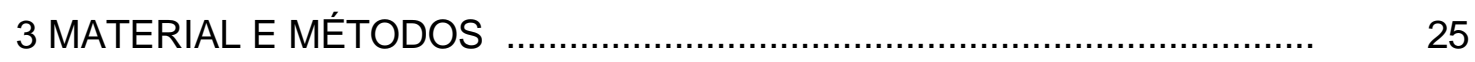

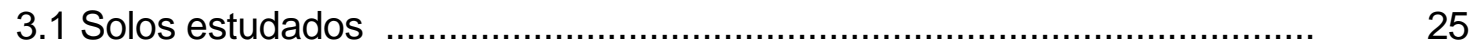

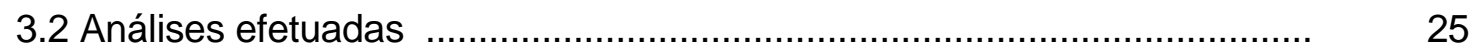




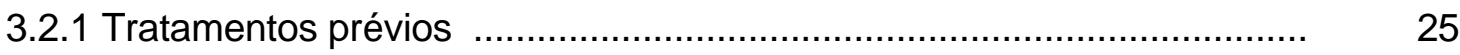

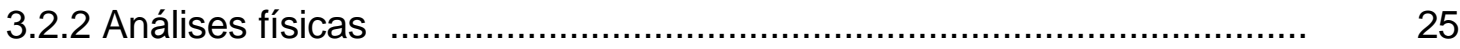

3.2.3 Análises químicas ................................................................... 25

3.2.3.1 Matéria orgânica ............................................................................. 27

3.2.3.2 Complexo sortivo ..................................................................... 27

3.2.3.3 Fósforo remanescente ................................................................ 27

3.2.3.4 Ataques sulfúrico e alcalino .......................................................... 28

3.2.3.5 Ferro e alumínio vinculados aos óxidos cristalinos e mal cristalizados $\quad 28$

3.2.3.6 Ferro e alumínio vinculados aos óxidos mal cristalizados ................... 29

3.2.4 Análises eletroquímicas ................................................................ 29

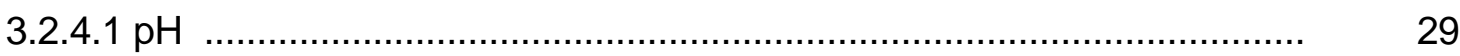

3.2.4.2 Ponto de efeito salino nulo ……............................................... 29

3.2.4.3 Capacidades de troca catiônica e aniônica (CTC e CTA) ................... 31

3.2.4.3.1 Capacidade de troca catiônica ................................................... 31

3.2.4.3.2 Capacidade de troca aniônica ....................................................... 31

3.2.5 Análises mineralógicas ............................................................ 32

3.2.5.1 Tratamento prévio das amostras …………................................... 32

3.2.5.2 Estimativa dos teores de caulinita e gibbsita .................................... 32

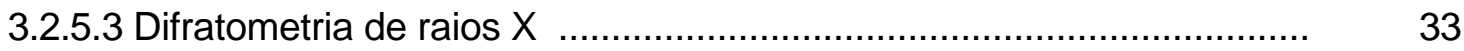

3.2.5.3.1 Fração argila desferrificada ......................................................... 33

3.2.5.3.2 Fração argila concentrada em óxidos de ferro ................................. 34

3.2.5.4 Cálculos mineralógicos .............................................................. 34

3.2.5.4.1 Estimativa da substituição por alumínio nos óxidos de ferro ........... 34

3.2.5.4.1.1 Hematita ........................................................................ 34

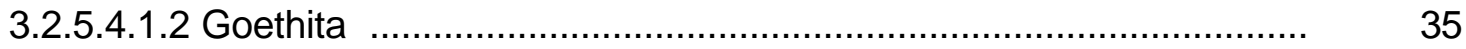

3.2.5.4.2 Relação hematita/(hematita + goethita) ……………………........ 35

3.2.5.4.3 Teores de hematita e goethita ................................................... 36

3.2.5.4.4 Teores de óxidos mal cristalizados …………………………... 36

3.2.5.4.5 Semiquantificação dos teores de minerais cristalinos e óxidos mal cristalizados na fração argila total 


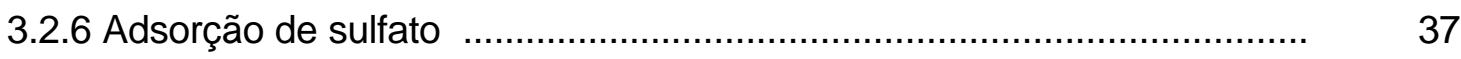

3.2.6.1 Isotermas de adsorção ............................................................ 37

3.2.6.2 Enxofre remanescente ................................................................ 39

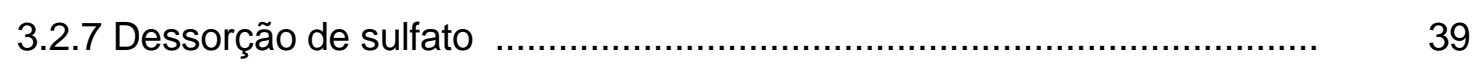

3.2.8 Análises estatísticas .................................................................. 40

4 RESULTADOS E DISCUSSÃO ……........................................................ 41

4.1 Caracterização física ………................................................................... 41

4.2 Caracterizações química e eletroquímica de rotina ................................ 42

4.3 Formas de ferro e alumínio e ataques sulfúrico e alcalino ........................ 44

4.4 Caracterização mineralógica .............................................................. 49

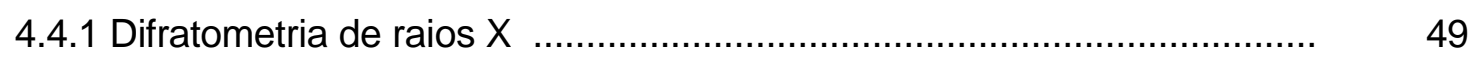

4.4.2 Análises semiquantitativas ……...................................................... 57

4.5 Caracterização eletroquímica …………………………………........ 63

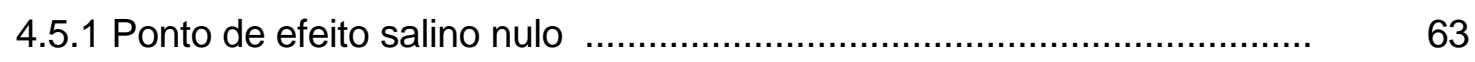

4.5.1.1 Determinação analítico-computacional a partir de dados de titulação

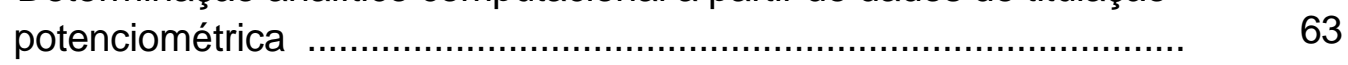

4.5.1.2 Estimativa do PESN a partir de dados de $\mathrm{pH}$................................. 71

4.5.1.3 Relações entre o PESN e o grau de intemperismo dos solos .......... 73

4.5.1.4 Relações entre o PESN e atributos mineralógicos ……….................. 74

4.5.1.5 Relações entre o PESN e outros atributos dos solos ......................... 78

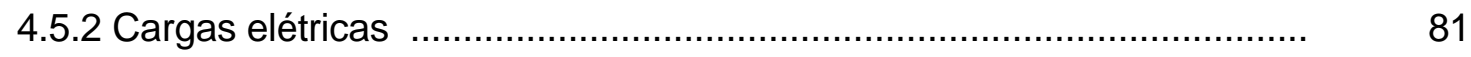

4.5.2.1 Métodos de determinação da CTC e estimativa da carga líquida ....... 81

4.5.2.2 Capacidade de troca aniônica …………………........................... 84

4.5.2.3 Cargas elétricas negativas de caráter permanente e variável ............. 88

4.5.3 pH em solução de $\mathrm{NaF} 1 \mathrm{~mol} \mathrm{~L}^{-1}(\mathrm{pH} \mathrm{NaF})$......................................... 90

4.6 Adsorção de sulfato ....................................................................... 98

4.6.1 Isotermas de adsorção e enxofre remanescente .................................. 98

4.6.2 Relações entre a adsorção de sulfato e atributos dos solos .................. 107

4.6.2.1 Granulometria ...................................................................... 107

4.6.2.2 Formas de ferro e alumínio ........................................................... 109 


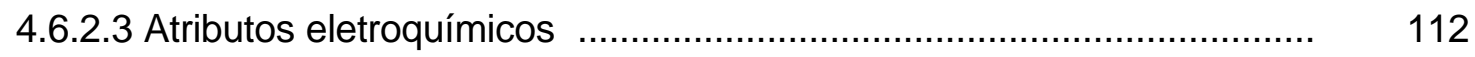

4.6.2.4 Teores de mineriais na fração argila ................................................. 115

4.7 Dessorção de sulfato .......................................................................... 122

4.7.1 Quantidades dessorvidas .......................................................... 122

4.7.2 Relações da dessorção com atributos dos solos ................................ 125

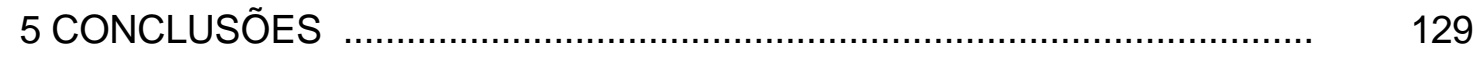

REFERÊNCIAS BIBLIOGRÁFICAS .................................................... 132 


\title{
ATRIBUTOS MINERALÓGICOS E ELETROQUÍMICOS, ADSORÇÃO E DESSORÇÃO DE SULFATO EM SOLOS PAULISTAS
}

\author{
Autor: MARCELO EDUARDO ALVES \\ Orientador: Prof. Dr. ARQUIMEDES LAVORENTI
}

\section{RESUMO}

O presente trabalho teve como objetivo principal avaliar as relações entre a composição mineralógica de solos representativos do Estado de São Paulo e alguns de seus atributos eletroquímicos como o ponto de efeito salino nulo (PESN) e a capacidade de troca aniônica (CTA). Especial atenção foi dada também àquantificação de cargas negativas de caráter permanente e à contrastação dos resultados com a composição mineralógica da fração argila, a qual foi avaliada de forma qualitativa e semiquantitativa. Além dos atributos eletroquímicos supracitados, a adsorção e a dessorção de sulfato, principal forma inorgânica de enxofre presente nos solos sob condições aeróbicas, foram estudadas visando-se à determinação de índices representativos desses fenômenos e à associação dos mesmos com atributos mineralógicos, químicos e eletroquímicos dos solos. Em uma primeira etapa, amostras coletadas em camadas subsuperficiais de quinze solos localizados em diferentes regiões do Estado de São Paulo foram submetidas à uma intensa caracterização mineralógica, química e eletroquímica. Além dessas avaliações, as amostras foram utilizadas como adsorvedores em estudos de adsorção e dessorção de sulfato. Em um 
momento posterior e por meio do tratamento estatístico dos dados, procurou-se analisar as relações individuais dos diversos atributos avaliados com o ponto de efeito salino nulo, capacidade de troca aniônica, adsorção e dessorção de sulfato. Os resultados experimentais obtidos durante a avaliação do ponto de efeito salino nulo das amostras permitiram o desenvolvimento de um programa computacional para o tratamento matemático dos referidos dados visando-se à determinação analítica do valor desse atributo eletroquímico. Testes realizados com dados obtidos por outros autores demonstraram a adequação do programa para a determinação rápida e nãosubjetiva do PESN. Em relação æ̀̀ cargas elétricas negativas de superfície, pôde-se verificar uma significativa presença de cargas de caráter permanente, fato que apresentou razoável concordância com a composição mineralógica das amostras. Contudo, faz-se necessária a contrastação de resultados obtidos com o método da adsorção de césio com quantidades de cargas permanentes determinadas por meio do uso de outros procedimentos metodológicos. Ao avaliar-se a capacidade de troca catiônica (CTC) das amostras, utilizando-se diferentes métodos, pôde-se observar que os solos com caráter ácrico estiveram dentre aqueles em que as maiores discrepâncias foram verificadas, fato que sugere a necessidade da reavaliação dos métodos empregados para a determinação da CTC efetiva nesses solos. Os procedimentos adotados permitiram verificar que os óxidos de alumínio mal cristalizados, presentes na fração argila, são os componentes mais diretamente associados ao ponto de efeito salino nulo e à capacidade de troca aniônica das amostras estudadas. Em relação à adsorção de sulfato, novamente observou-se acentuada relação direta entre o teor dos óxidos de alumínio mal cristalizados e a capacidade adsortiva das amostras bem como com a afinidade apresentada pela fase sólida em relação ao referido ânion. A gibbsita e os óxidos de alumínio mal cristalizados são os constituintes inorgânicos da fase sólida mais diretamente associados à restrição à dessorção de sulfato nas amostras avaliadas, ao passo que a liberação do sulfato retido apresentou relação direta com o teor de caulinita. Esses dados indicam que as aplicações de gesso agrícola devem ser feitas com maior cautela em solos cauliníticos. Em relação aos atributos de fácil e rápida determinação, o pH das amostras medido em solução de fluoreto de sódio ( $\mathrm{pH} \mathrm{NaF)} \mathrm{apresentou}$ estreita relação com a presença de óxidos de alumínio nas amostras estudadas e, por essa razão, mostrou-se como um índice bastante promissor para a avaliação indireta 
da capacidade de retenção aniônica de amostras de camadas subsuperficiais de solos das regiões tropicais. Finalmente, um grande número de correlações não significativas obsevadas entre os teores de óxidos de ferro cristalinos (hematita e goethita) tanto para com atributos eletroquímicos quanto para com a adsorção e dessorção de sulfato parece indicar a existência de acentuada variabilidade comportamental para esses minerais nas amostras estudadas. Desse modo, novos estudos devem ser realizados com os referidos óxidos de ferro visando-se analisar a influência da morfologia, tamanho de cristais e grau de cristalinidade sobre os atributos eletroquímicos e propriedades adsortivas desses minerais. Igualmente, o desenvolvimento de trabalhos de pesquisa de natureza similar envolvendo a gibbsita são também necessários, haja vista a completa ausência de informações relacionadas àvariabilidade comportamental desse óxido de alumínio. 


\title{
MINERALOGICAL AND ELECTROCHEMICAL PROPERTIES, SULFATE ADSORPTION AND DESORPTION IN SOILS FROM SÃO PAULO STATE
}

\author{
Author: MARCELO EDUARDO ALVES \\ Adviser: Prof. Dr. ARQUIMEDES LAVORENTI
}

\section{SUMMARY}

The present research aimed at studying the relationships between the mineralogical composition of representative soils from São Paulo State and some of their electrochemical properties, particularly the point of zero salt effect (PZSE) and the anion exchange capacity (AEC). Additionally, it was given special attention to the presence of permanent negative charges in those soils, whose magnitudes were also associated with the mineralogical composition of their clay fractions, which was evaluated by using qualitative and semiquantitative approaches. Besides the above mentioned electrochemical properties, the adsorption and desorption of sulfate, the main inorganic form of sulfur found in soils under aerobic conditions, were studied in order to associate the representative indexes of these phenomena with mineralogical, chemical and electrochemical soil properties. Initially, samples collected in subsurface layers of fifteen soils situated in different regions of São Paulo State were highly characterized as for their mineralogical, chemical and electrochemical properties 
Besides these evaluations, the soil samples were used as adsorbents in studies of sulfate adsorption and desorption reactions. After this, and through the statistical analyses of data, it was aimed at verifying the individual relationships of the evaluated properties with the PZSE, AEC, sulfate adsorption and desorption indexes. The experimental results obtained during the evaluation of the PZSE values of samples, gave us the possibility of the development of one software for mathematical manipulation of them in order to allow the analytical determination of the above mentioned electrochemical property. The software was evaluated through the analyses of potentiometric titration data from experiments of other authors. The results showed very good agreement between PZSE values calculated by the software and those determined by the authors. By this reason, this approach can be considered very useful for this determination. In relation to surface charges, it was possible to verify reasonable amounts of permanent negative charges in evaluated soil samples and good correspondence of them with soil mineralogical properties. However, more studies are necessary in order to compare the results of cesium adsorption method, employed for this determination in the present research, with ones from other methodologies. The determination of cation exchange capacity (CEC) values through different approaches have shown that the soil samples with acric character were among the ones that present the biggest discrepancies. These results suggest the necessity of reevaluation for the usual methods employed to measurements of CEC values in soils with acric character. The methods used in this research allowed us to verify that the contents of amorphous aluminum oxides in the clay fraction present direct associations with PZSE and $A E C$ values determined in soil samples. In relation to sulfate adsorption, it was also observed the positive effect of amorphous aluminum oxides on the sulfate adsorptive capacities of the studied soils. In the same way, the content of above mentioned oxides present significative and direct correlation with the affinity of surfaces by sulfate ions. The gibbsite and amorphous aluminum oxides are the clay fraction constituents associated with the restriction to sulfate desorption in evaluated soil samples; on the other hand, the transference of sulfate ions from solid surfaces to soil solutions was favored by the high kaolinite contents. These data suggest that the use of gypsum in kaolinitic soils with low contents of oxides must be done with more criteria. 
Considering the soil properties whose determinations are not time consuming, the $\mathrm{pH}$ values evaluated in suspensions of soil-NaF $1 \mathrm{~mol} \mathrm{~L}^{-1}$ solution $(\mathrm{pH} \mathrm{NaF})$ presented very good associations with the aluminum oxides contents of soil samples and, by this reason, it showed also significative correlations with soil sulfate adsorption capacity. These founds indicate that the $\mathrm{pH} \mathrm{NaF}$ is a very promising index for the indirect evaluation of the anion retention capacity of samples from subsurface layers of tropical soils. Finally, the great number of non-significative correlations verified in this research between crystalline iron oxides (hematite and goethite) contents and electrochemical properties or sulfate adsorption/desorption indexes suggest the existence of nonsystematic variations in their intrinsic properties. So, it is very important the establishment of new researches with the objective of acquiring more information about the influence of morphology and crystals size and crystallinity of these adsorbents on their electrochemical properties and adsorptive capacities. These considerations are also applied to gibbsite, since there is no information about this topic associated to this mineral. 


\section{INTRODUÇÃO}

As propriedades químicas, eletroquímicas e físicas dos solos dependem, em grande parte, dos minerais neles presentes. A composição mineralógica dos solos, tanto no que se refere aos aspectos quantitativos quanto às propriedades intrínsecas dos minerais presentes, exerce grande influência sobre atributos como o ponto de efeito salino nulo (PESN), quantidade, natureza e caráter das cargas elétricas do complexo sortivo bem como sobre a adsorção e dessorção iônicas. Em conseqüência disso, pode-se concluir que a maior ou menor mobilidade observada para um íon em um solo, assim como sua fitodisponibilidade, são definidas de modo bastante acentuado pela natureza e quantidade dos componentes coloidais inorgânicos de sua fase sólida.

O ânion sulfato $\left(\mathrm{SO}_{4}{ }^{2}\right)$ é a forma mineral predominante de enxofre encontrada no solo, em condições aeróbicas, e também a principal forma do elemento absorvida pelas plantas. A retenção desse íon pela fase sólida do solo exerce grande influência sobre sua disponibilidade para os vegetais e sobre sua movimentação no perfil, a qual, por sua vez, pode influenciar a lixiviação catiônica.

Ao contrário do que se observa para o fosfato, escassos são os trabalhos realizados com solos brasileiros voltados para uma melhor compreensão do fenômeno de adsorção de sulfato, tanto no que se refere ao estudo dos componentes mineralógicos da fração argila sobre o fenômeno, quanto àidentificação de atributos de fácil e rápida caracterização que permitam a estimativa da magnitude da capacidade de um solo em reter esse íon. Por outro lado, e igualmente para o fosfato, a dessorção quase sempre mereceu pouca atenção por parte dos pesquisadores.

Nesse sentido, considerando-se que o estabelecimento de relações entre atributos de solos de uma região permite tanto uma melhor compreensão dos 
fenômenos que neles ocorrem, quanto a identificação de características que permitam a realização de inferências regionais sobre o comportamento dos mesmos em relação aos seus atributos eletroquímicos e aos fenômenos de adsorção e dessorção de sulfato, propôs-se, com o presente trabalho, a caracterização de atributos físicos, químicos, eletroquímicos e mineralógicos de amostras coletadas em camadas subsuperficiais de solos representativos do Estado de São Paulo e a avaliação dos fenômenos de adsorção e dessorção de sulfato nas mesmas, mediante o estabelecimento de índices característicos dos mesmos.

Por meio do tratamento estatístico dos resultados experimentais, procurou-se analisar as relações individuais dos diversos atributos avaliados, em especial dos mineralógicos, com características eletroquímicas das amostras, bem como, com os índices de adsorção e dessorção de sulfato nelas determinados. 


\section{REVISÃO DE LITERATURA}

Assim como a maioria dos solos brasileiros, grande parte dos solos do Estado de São Paulo apresenta sua fração argila constituída, em sua quase totalidade, por caulinita, gibbsita, hematita, goethita e óxidos de ferro e alumínio mal cristalizados. Tal composição se deve ao avançado grau de intemperismo que esses solos apresentam, alcançando seu ponto máximo nos solos com caráter ácrico, situados em extensas áreas na região norte do Estado.

Embora os minerais e óxidos supracitados apresentem predominância quantitativa na maioria dos solos paulistas, deve-se considerar também a possibilidade de ocorrência de argilominerais do tipo 2:1, como a vermiculita e a ilita, que podem influenciar, sobremaneira, os atributos eletroquímicos e, por conseqüência, os fenômenos de adsorção e dessorção iônica ocorrentes nos mesmos.

Dentre os atributos eletroquímicos dos solos intemperizados das regiões tropicais, merecem destaque o ponto de efeito salino nulo e a capacidade de troca aniônica, cujas magnitudes estão diretamente associadas ao estádio de desenvolvimento desses solos. Esses atributos são um reflexo da composição mineralógica da fração argila, fato que demonstra a importância da obtenção de informações mais detalhadas, relativas àcontribuição dos componentes inorgânicos da fase sólida nas magnitudes dos referidos atributos.

A adsorção e a dessorção de sulfato relacionam-se diretamente com a utilização dos solos paulistas, evidenciando a necessidade de melhor compreensão desses fenômenos, em face da possibilidade de que a movimentação vertical desse ín no perfil possa favorecer a lixiviação de nutrientes catiônicos reduzindo assim a disponibilidade dos mesmos às culturas agrícolas.

As relações entre a mineralogia da fração argila e os fenômenos de adsorção e dessorção de sulfato podem influir de maneira determinante na dinâmica desse íon nos 
solos e, conseqüentemente na movimentação de cátions trocáveis. Esse fato evidencia a necessidade de melhor compreensão dessas relações, que pode ser alcançada por meio de uma caracterização mais aprofundada da mineralogia da fração argila dos solos, no estabelecimento de índices de adsorção e dessorção aniônicas e na associação desses dados por meio de técnicas estatísticas.

Além disso, é também de grande interesse a identificação de um atributo de rápida determinação que apresente capacidade de predição dessas relações.

\subsection{Mineralogia da fração argila dos solos tropicais}

Os solos tropicais apresentam elevado grau de intemperismo, com mineralogia da fração argila dominada por minerais silicatados do tipo 1:1 e óxidos de ferro e alumínio (Moniz, 1975; Fontes \& Weed, 1991; Resende et al., 1995). Os Latossolos são os que melhor representam as tendências pedogenéticas dos solos tropicais, sendo definidos como aqueles que apresentam um horizonte subsuperficial mineral B latossólico, que evidencia seu estádio avançado de intemperismo, como mostrado pela completa ou quase total alteração e decomposição de minerais facilmente intemperizáveis, pela elevada profundidade e pela baixa capacidade de troca catiônica (Camargo et al., 1988). Além dos Latossolos, há destacada presença de Argissolos, os quais se apresentam com diferentes graus de intemperismo (Oliveira et al, 1992).

Os Latossolos apresentam mineralogia da fração argila basicamente dominada por caulinita, gibbsita, goethita e hematita, além de óxidos de ferro e alumínio mal cristalizados; os Argissolos, por sua vez, tendem a apresentar, além dos referidos minerais e óxidos mal cristalizados, argilominerais do tipo 2:1, como a vermiculita, clorita e ilita. Embora a composição mineralógica predominante nos solos tropicais possa ser considerada simples, variações que podem ocorrer dentro e entre os grupos de minerais quanto ao tamanho de partículas e superfície específica, faces expostas, graus de substituição isomórfica e cristalinidade podem proporcionar grande variabilidade ao comportamento desses solos dentro de uma mesma classe (Schwertmann \& Herbillon, 1992; Netto, 1996). 


\subsection{1 Óxidos de ferro}

Embora Cornell \& Schwertmann (1996) relatem a existência de 16 tipos de óxidos de ferro, entre naturais e sintéticos, a principal forma de ocorrência destes nos solos tropicais se deve, como já destacado, a alguns dos minerais cristalinos, principalmente hematita e goethita, e a formas mal cristalizadas como a ferrihidrita (Kämpf \& Curi, 2000).

Os óxidos de ferro estão intimamente vinculados aos fenômenos de estruturação e agregação do solo. Sua associação com a caulinita e, algumas vezes com a gibbsita em Latossolos brasileiros proporciona uma estrutura em que as partículas de argila estão altamente agregadas, podendo se comportar como partículas de areia (Fontes, 1992). A participação dos óxidos de ferro na constituição de um solo pode conferir, portanto, propriedades físicas desejáveis de maior permeabilidade à água e maior resistência à erosão, comparado a outros solos de mineralogia similar, mas com menores teores desses minerais. Esses mesmos óxidos ainda influenciam outras propriedades do solo, como a cor e a retenção de íons.

Nos ambientes aeróbicos, a formação dos óxidos de ferro inicia-se com a liberação do $\mathrm{Fe}^{2+}$ dos minerais primários pela intemperização e sua imediata oxidação a $\mathrm{Fe}^{3+}$, ou então, por qualquer outra fonte de $\mathrm{Fe}^{3+}$, como, por exemplo, a dissolução de óxidos já existentes. Na seqüência, os íons $\mathrm{Fe}^{3+}$ precipitam como ferrihidrita ou goethita, dependendo de qual produto de solubilidade é ultrapassado primeiro, o da ferrihidrita é mais elevado. A hematita é formada a partir de seu precursor obrigatório, a ferrihidrita que, por sua vez pode também se transformar em goethita (Cornell \& Schwertmann, 1996; Kämpf \& Curi, 2000).

Quanto à presença nos solos, a goethita pode ser considerada quase que onipresente, enquanto a hematita pode não ser detectada em determinadas amostras. A presença e mesmo a indicação quantitativa dos óxidos de ferro presentes nos solos, normalmente, são expressas em termos da relação verificada entre os teores de hematita e goethita, ou seja, valores de $\mathrm{Hm} /(\mathrm{Hm}+\mathrm{Gt})$ ou $\mathrm{Gt} /(\mathrm{Gt}+\mathrm{Hm})$ obtidos principalmente a partir de informações de difratometria de raios $\mathrm{X}$.

As formas de cálculo dessa relação utilizam equações que relacionam a área sob ou a intensidade de determinados picos dos minerais nos difratogramas de raios $\mathrm{X}$. 
Torrent \& Cabedo (1986) usaram as áreas sob os picos $\mathrm{Gt}_{111}$ e $\mathrm{Hm}_{110}$ avaliadas em difratogramas diferenciais referentes a solos calcários e vermelhos da Espanha. Para solos brasileiros, Bognola (1995) e Netto (1996) utilizaram as áreas sob as reflexões $\mathrm{Gt}_{110}$ e $\mathrm{Hm}_{104}$ em difratogramas de concentrados de óxidos de ferro; Kämpf (1988), a área referentes aos picos $\mathrm{Hm}_{012}$ ou $\mathrm{Hm}_{104}$ e $\mathrm{Gt}_{110}$; e Motta \& Kämpf (1992), as intensidades de $\mathrm{Gt}_{110}$ e $\mathrm{Hm}_{012}$.

Uma alternativa à difratometria de raios $X$ na estimativa da relação entre $\infty$ óxidos de ferro é a espectroscopia Mössbauer, utilizada com sucesso em solos brasileiros (Fabris et al., 1985; Fontes et al., 1991). Além de sua utilização na quantificação dos minerais hematita e goethita do solo, essa relação pode ser usada para classificar os Latossolos em goethíticos, aqueles que apresentam $\mathrm{Hm} /(\mathrm{Hm}+\mathrm{Gt})<$ 0,2; hematíticos, com valores de $\mathrm{Hm} /(\mathrm{Hm}+\mathrm{Gt})>0,6$; e criptogoethíticos, intermediários aos limites definidos das classes anteriores (Kämpf et al., 1988).

Graças à sua natureza metaestável, a presença significativa de ferrihidrita identifica solos pouco intemperizados ou pedoambientes em que sua transformação em óxidos estáveis é inibida ou retardada (Kämpf \& Curi, 2000). Segundo Schwertmann (1985) os principais agentes inibitórios da cristalização da ferrihidrita são representados pela matéria orgânica e pelos fosfatos e silicatos solúveis. Desse modo e considerando-se a possibilidade de diferentes intensidades de inibição, parece ser possível a existência de variabilidade comportamental para a ferrihidrita, cujos teores podem ser quantificados por meio de extração do ferro com oxalato de amônio (Parfitt \& Childs, 1988).

Os diferentes tipos de óxidos de ferro podem apresentar uma substituição parcial de Fe por outros cátions. Nos solos das regiões tropicais, a substituição mais comum é a do Fe pelo Al que, segundo Cornell \& Schwertmann (1996) parece ser mais uma regra que exceção na natureza, principalmente para goethitas.

Por ser o íon $\mathrm{Al}^{3+}$ menor que o íon $\mathrm{Fe}^{3+}$ (Schulze, 1984), a substituição do segundo pelo primeiro promove alterações na estrutura dos óxidos de ferro, resultando na diminuição dos parâmetros da célula unitária. Esse fato é utilizado para a estimativa da referida substituição em óxidos de ferro por meio de difratometria de raios $\mathrm{X}$, considerando-se que existe uma relação linear entre dimensões da célula unitária e o conteúdo de alumínio nos óxidos, assim como observado para amostras sintéticas. 
Dessa forma, por meio das medições efetuadas nos deslocamentos dos picos e da comparação com amostras consideradas puras e sem substituição, pode-se estabelecer a relação entre tal deslocamento e a quantidade substituída.

Dentre as equações utilizadas com esse objetivo, destaca-se, para o cálculo da substituição na goethita, a proposta por Schulze (1984) baseada na dimensão c da célula unitária e nos espaçamentos interplanares $d_{111}$ e $d_{110}$. Para a hematita, a mais comum é a de Schwertmann et al. (1979) desenvolvida a partir do estudo da referida substituição em hematitas sintetizadas a $70^{\circ} \mathrm{C}$ e cuja aplicação a hematitas pedogenéticas foi, recentemente, estudada por Kämpf \& Schwertmann (1988). Essa equação é baseada na dimensão a da célula unitária estimada a partir da posição do pico $\mathrm{Hm}_{110}$ ou da referente ao pico $\mathrm{Hm}_{300}$.

Maiores valores de substituição são normalmente associados à goethita, em comparação com a hematita quando ambos os óxidos coexistem em uma mesma amostra (Curi \& Franzmeier, 1984; Schwertmann \& Latham, 1986; Singh \& Gilkes, 1992a). A goethita apresenta maior capacidade de incorporação de alumínio em sua estrutura cristalina quando ambos os minerais competem pelo elemento (Schwertmann \& Kämpf, 1985). Entretanto, deve também ser destacada a possibilidade de altos valores de substituição para a hematita, como indicado por Fabris et al. (1985) que comentam a obtenção de hematitas sintéticas com mais de $0,30 \mathrm{~mol} \mathrm{~mol}^{-1}$.

A substituição por alumínio pode afetar a forma dos óxidos de ferro (Schulze \& Schwertmann, 1984; Schwertmann, 1984). Esses autores verificaram que as goethitas sintéticas apresentaram-se mais curtas, estreitas e espessas na presença do fenômeno. Também Lewis \& Schwertmann (1979) verificaram goethitas mais finas com bordas menos agudas, com o aumento da substituição. Amarasiriwardena et al. (1988) notaram que as goethitas sintéticas não-substituídas apresentaram-se alongadas e que o comprimento na direção c diminuiu com o aumento da substituição. No caso das hematitas sintéticas, as não-substituídas apresentaram-se cilíndricas, e a substituição por alumínio também induziu uma redução no seu comprimento.

Além de modificações morfológicas, a substituição por Al pode acarretar alterações na estabilidade estrutural dos óxidos de ferro. Schulze \& Schwertmann (1984) verificaram um sistemático aumento na temperatura de desidroxilação com o aumento na incorporação de Al em goethitas sintetizadas sob as mesmas condições. 
Uma maior estabilidade térmica decorrente do aumento da substituição por alumínio foi também observada por Kämpf \& Schwertmann (1995) para goethitas derivadas de saprólitos de basalto.

Embora a hematita e a goethita sejam as fases dominantes na mineralogia dos solos, outros óxidos de ferro podem ser ainda observados. A maghemita, de ocorrência principalmente vinculada a amostras de solos derivados de rochas máficas ou itabiritos, é constantemente relacionada em Latossolos brasileiros (Curi \& Franzmeier, 1984; Kämpf \& Schwertmann, 1998). A gênese deste mineral, além da vertente pedogenética associada à oxidação da magnetita ou mesmo a partir de transformações da lepidocrocita (Taylor \& Schwertmann, 1974) pode estar vinculada ao efeito do fogo (Schwertmann \& Fitzpatrick, 1992; Schwertmann \& Latham, 1986), por meio de transformações de outros minerais em presença de matéria orgânica. Schwertmann \& Fechter (1984) obtiveram maghemitas a partir do aquecimento de uma goethita sintética com alta substituição por alumínio em presença de sacarose, a qual foi empregada como representante da matéria orgânica.

Já a magnetita que, da mesma forma que a maghemita, apresenta propriedades magnéticas, é considerada normalmente como de origem litogenética, ou seja, herdada diretamente do material parental e não pedogenética (Cornell \& Schwertmann, 1996).

A ilmenita é um óxido de ferro e titânio também presente nas frações mais grosseiras do solo, estando associada aos mesmos materiais de origem que a magnetita (Allen \& Hajek, 1989).

A lepidocrocita constitui-se em um óxido de ferro mal cristalizado cuja presença está associada aos primeiros estádios de intemperismo, bem como a condições redutoras e ambientes hidromórficos (Schwertmann \& Kämpf, 1983). Esse mineral, por sua coloração alaranjada proeminente, indica a prevalência de condições redoxmórficas que proporcionam a formação de $\mathrm{Fe}^{2+}$ no perfil do solo (Kämpf \& Curi, 2000). 


\subsection{2 Óxidos de alumínio}

A gibbsita representa quase que exclusivamente o único óxido de alumínio cristalino presente em solos das regiões tropicais e está íntima e diretamente associada à intensidade do intemperismo. Também pode ser encontrada em solos mais jovens, como Cambissolos, devido àpossibilidade de vir a ser um dos primeiros produtos formados a partir do intemperismo dos feldspatos. Sua presença é muito comum em Latossolos e Argissolos brasileiros (Fontes \& Weed, 1991; Mesquita Filho \& Torrent, 1993; Alleoni, 1996; Netto, 1996).

Os cristais de gibbsitas sintéticas apresentam forma hexagonal plana, com predomínio da face (001) (Parfitt, 1978). Amostras sintéticas observadas por Russel et al, (1974) ao microscópio eletrônico, apresentaram diâmetros da ordem de $250 \mathrm{~mm}$ e espessura de $9 \mathrm{~mm}$, com uma superfície específica calculada de $96 \mathrm{~m}^{2} \mathrm{~g}^{-1}$ para as faces principais (001) e $8 \mathrm{~m}^{2} \mathrm{~g}^{-1}$ para as faces das bordas. Já, Mesquita Filho \& Torrente (1993) verificaram que as gibbsitas de solos do cerrado brasileiro apresentavam-se como cristais subarredondados de 50 a 100 nm de diâmetro, com superfície calculada de $58 \mathrm{~m}^{2} \mathrm{~g}^{-1}$.

Apesar de tratada com menor intensidade em relação principalmente aos óxidos de ferro, no que diz respeito à adsorção aniônica, a gibbsita pode exercer importante e determinante influência nesse fenômeno, principalmente em solos onde se apresenta com maior expressão (Ker, 1995).

Além da gibbsita, deve-se considerar também os óxidos de alumínio mal cristalizados cujos teores podem ser avaliados por meio da extração do alumínio com oxalato de amônio (Parfitt \& Childs, 1988).

Esses compostos caracterizam-se por apresentarem superfície específica e reatividade em relação à adsorção de ânions bem maiores que a de suas formas cristalinas (Bohn et al., 1979). De acordo com Hsu (1989), embora a presença desses óxidos nos solos seja freqüentemente relatada na literatura, pouco se conhece sobre a estrutura desses materiais. Recentemente, Goldberg et al. (2001) verificaram significativas modificações nas superfícies específicas de óxidos de alumínio mal cristalizados, sintetizados sob diferentes condições, ao agitarem suspensões aquosas dos mesmos por períodos de tempo de até nove dias. Desse modo, estudos de 
adsorção e dessorção iônicas realizados com as formas sintéticas desses óxidos podem apresentar resultados pouco realísticos, haja vista a baixa estabilidade desses compostos.

\subsubsection{Caulinita}

A maior parte dos solos dos trópicos úmidos tem sua fração argila dominada pela caulinita (Hughes \& Brown, 1979) . Trata-se do principal e quase que 0 único mineral representante dos silicatados que ocorrem em quantidades significativas nos Latossolos e Argissolos.

A caulinita apresenta estrutura laminar formada pela união de uma camada de tetraedros de silício ligada por pontes de hidrogênio a uma camada de octaedros de alumínio. Partículas individuais desse mineral podem atingir até $5 \mu \mathrm{m}$ de largura e 2 $\mu \mathrm{m}$ de espessura (Besoain, 1985). As caulinitas de solos de cerrado brasileiro observadas por Mesquita Filho \& Torrent (1993) apresentavam-se com placas finas de 40 a $200 \mathrm{~nm}$ de diâmetro, com superfície específica calculada de $53 \mathrm{~m}^{2} \mathrm{~g}^{-1}$.

Os cristais de caulinita presentes em solos intemperizados das regiões tropicais apresentam diferenças em relação às caulinitas de depósitos geológicos. Nos solos tropicais, os cristais de caulinita podem ser muitos menores que os das caulinitas padrão, o que thes confere maior superfície específica (Schwertmann \& Herbillon, 1992). Além de uma redução de tamanho, a incorporação de Fe na estrutura da caulinita apresenta uma acentuada correlação inversa com o grau de cristalinidade desse mineral (Mestdagh et al., 1980), o que também contribui para o aumento de sua superfície específica e portanto de sua reatividade.

Apesar de normalmente ser relegada a segundo plano quanto aos atributos eletroquímicos do solo, tendo em vista sua baixa CTC e baixa superfície específica, a caulinita pode apresentar significativa participação nos fenômenos de adsorção e dessorção de sulfato (Aylmore et al., 1967; Rao \& Sridharan, 1984). 


\subsubsection{Outros minerais}

Além das fases comentadas anteriormente, que são as predominantes nos Latossolos e na maior parte do Argissolos, outros minerais de menor expressão quantitativa podem ser identificados, entre ele os do tipo 2:1, os interestratificados e os com hidróxi nas entrecamadas. Nesse último grupo, merece destaque a vermiculita com hidróxi nas entrecamadas (VHE) (Fontes, 1990) que, possivelmente, seja o de maior expressão dentre os comentados neste tópico, tendo em vista sua maior resistência ao intemperismo. A VHE tem sido largamente observada em solos brasileiros de distintas classes (Fontes \& Weed, 1991; Netto, 1996).

Micas, rutilo e anatásio também são outros minerais geralmente identificados nos Latossolos, sendo a ilita quase sempre associada aos Argissolos (Galvão \& Schulze, 1996; Alleoni, 1996; Netto, 1996).

\subsection{Ponto de efeito salino nulo}

O ponto de efeito salino nulo (PESN), termo originalmente proposto por Parker et al. (1979) e adaptado para a língua portuguesa por Alleoni \& Camargo (1993), corresponde ao valor de pH no qual a concentração salina da solução que se encontra em contato com a fase sólida não exerce influência sobre a magnitude das cargas elétricas de caráter variável que se manifestam na superfície das partículas coloidais existentes no solo (Sposito, 1989). A determinação do valor desse atributo é de grande importância em estudos de físico-química dos solos com cargas variáveis, pois alguns fenômenos eletroquímicos que ocorrem na interface sólido-líquido são influenciados pela distribuição superficial de cargas elétricas, que varia em função da diferença existente entre os valores de $\mathrm{pH}$ e de PESN. Além disso, fenômenos eletroquímicos como a adsorção específica de cátions e ânions podem promover modificações na distribuição superficial de cargas, as quais podem se refletir em mudanças no valor do PESN.

Na literatura, muitos são os trabalhos que mencionam o termo ponto de carga zero (PCZ). Em alguns deles, como o de Raij \& Peech (1972), verifica-se que apesar dos autores terem feito menção ao PCZ houve, na realidade, a determinação do 
PESN. Contudo, como a maior parte dos trabalhos faz menção ao PCZ e considerando-se a estreita associação existente entre esse atributo e o PESN, em especial para os solos tropicais, esse termo também será utilizado durante a apresentação do presente tópico.

O valor do PCZ dos minerais comumente presentes no solo varia muito de acordo com o método utilizado para sua determinação. Apesar da grande variação de valores de PCZ relatados para um mesmo mineral, há certa concordância acerca da tendência geral dos valores. Os dados disponíveis indicam que os óxidos de ferro e de alumínio têm PCZ mais elevados, enquanto os aluminossilicatos e a matéria orgânica têm PCZ mais baixos. Essas informações indicam que solos mais intemperizados apresentam maiores valores de PCZ em decorrência de sua mineralogia mais oxídica, conforme mostram os resultados encontrados por Nascimento et al. (1988) e Curi et al. (1993).

Os óxidos de ferro como a hematita, goethita e ferrihidrita apresentam PCZ variando entre 7 e 9 (MacBride, 1989; Schwertmann \& Taylor, 1989; Besoain, 1985). Vários óxidos de alumínio têm PCZ compreendidos entre 8 e 9,2 unidade de pH (Hsu, 1989). Para a caulinita, atribui-se um valor médio em torno de 4,6 para o seu PCZ (Stumm \& Morgan, 1981).

Sabe-se que as propriedades químicas do cátion central que compõe um óxido ou hidróxido têm influência decisiva no valor de seu PCZ (McBride, 1989). Quanto maior a carga e menor o raio iônico desse cátion, maior será sua capacidade de atrair elétrons do oxigênio ao qual se encontra ligado. Isso faz com que o oxigênio passe a atrair com mais intensidade o par de elétrons por ele compartilhado com o átomo de hidrogênio do grupo $\mathrm{MO}-\mathrm{H}$ de superfície, o que resulta em uma maior facilidade de desprotonação do referido grupo, fato que se traduz em um menor valor de PCZ para o mineral.

Apesar de a caulinita não ser um óxido, a aplicação das considerações acima apresentadas ao seu comportamento eletroquímico explicam satisfatoriamente o fato desse mineral apresentar um PCZ menor que os dos óxidos. Comparativamente aos óxidos cristalinos de ferro e de alumínio, a caulinita é o único mineral que apresenta um cátion tetravalente em sua estrutura $\left(\mathrm{Si}^{4+}\right)$, fator que seria responsável pelo seu menor PCZ. Em relação aos óxidos cristalinos de ferro e de alumínio, embora seus 
cátions apresentem mesmo estado de oxidação (3+), há diferença quanto ao raio iônico dos referidos cátions, que por ser menor para o alumínio (Parks, 1965) faz com que o PCZ da gibbsita apresente menor valor que os da hematita e da goethita. Esses raciocínios explicariam também o fato de solos com maior relação entre os teores de caulinita e gibbsita apresentarem menor PCZ, assim como verificado por Chagas et al. (1993).

Além da influência dos constituintes inorgânicos, há que se considerar também a influência da matéria orgânica sobre o PCZ, assim como verificado por Siqueira et al. (1990) que encontraram correlação significativa entre o PCZ e o teor de carbono orgânico ao longo do perfil de cinco solos estudados. Verificaram ainda que o grau de contribuição da matéria orgânica para o abaixamento do PCZ dependeu do grau de intemperismo do solo, sendo que os solos de menor Ki (mais oxídicos) tiveram maior queda no PCZ, ao ponto de um Latossolo Vermelho com alto teor de ferro apresentar um decréscimo de 1,3 unidades de PCZ para cada unidade de carbono orgânico.

Há na literatura poucos trabalhos que analisaram as relações de minerais pedogenéticos com o PESN de solos brasileiros. Silva et al. (1996) verificaram as relações entre o PESN e vários atributos de solos de 19 Latossolos brasileiros observando melhores correlações do referido atributo eletroquímico com o índice Ki e com a relação entre os teores de caulinita e gibbsita. Contudo, não foram considerados de forma direta nessas correlações teores de minerais como a hematita e goethita bem como os dos óxidos de alumínio mal cristalizados.

Embora o método da titulação potenciométrica empregado na determinação do PESN seja bem estabelecido (Raij \& Peech, 1972; Costa et al., 1984), Meijer \& Buurman (1987) mencionam que, ao contrário do que ocorre para mineriais sintéticos, raramente observa-se um único ponto de interseção para as curvas de titulação potenciométrica quando a determinação do PESN é efetuada em amostras de solo. Segundo esses autores, a adição de soluções salinas ácidas e alcalinas às subamostras de solo durante a execução do método de titulação potenciométrica pode resultar em: alterações nas atividades de íons $\mathrm{H}^{+}$e $\mathrm{OH}^{-}$na solução em decorrência de alterações nas proporções de cátions e ânions adsorvidos; aumento na dissociação de radicais orgânicos com o aumento do $\mathrm{pH}$ e da concentração de contra-íons; modificações das reações de complexação de metais pela matéria orgânica com as 
variações de $\mathrm{pH}$ e heterogeneidade quanto à formação de cargas por protonação e desprotonação de grupos -OH de superfície dos diferentes óxidos presentes.

Nos casos em que não se observa um único ponto de cruzamento entre as curvas de titulação potenciométrica, algo muito comum ao se realizar a determinação do PESN em amostras de solos menos intemperizados, o ponto central do triângulo formado pelos pontos de intersecção das três curvas eletrolíticas é, por vezes, considerado como sendo o valor do PESN. Contudo, assim como também destacam Meijer \& Buurman (1987) essa consideração acaba sendo um tanto quanto arbitrária e, assim como o traçado manual das curvas de titulação, bastante subjetiva.

Nesse sentido e considerando-se as possibilidades oferecidas pela informática, seria de grande utilidade o desenvolvimento de um procedimento automatizado para o tratamento de dados de titulação potenciométrica que, além de proporcionar redução no tempo requerido e na subjetividade envolvida com o método convencional, pudesse informar o grau de precisão do valor de PESN estimado.

\subsection{Cargas elétricas de superfície}

Embora a eletroquímica dos solos com cargas variáveis tenha apresentado sensível desenvolvimento após o trabalho seminal de Raij \& Peech (1972), é ainda imprescindível o aprimoramento dos estudos que visam associar ocomportamento eletroquímico dos solos àsua mineralogia (Fontes et al., 2001).

Considerando-se que a manifestação de cargas elétricas exerce influência em diversos fenômenos como a dispersão de floculação de colóides (Chorom et al., 1994), troca catiônica e adsorção de ânions (Gillman, 1984; Wong et al., 1990; Qafoku \& Sumner, 2001; Ludwig et al., 2001; Rasiah \& Armour, 2001), é essencial também a avaliação dos métodos disponíveis para a caracterização dessas cargas por meio da contrastação de seus resultados quando aplicados a diferentes solos.

O comportamento eletroquímico dos solos com menores teores de matéria orgânica é um reflexo das propriedades dos minerais neles presentes (Moniz, 1975). Desse modo, face a seu acentuado estádio de intemperismo, os solos das regiões tropicais apresentam predomínio de cargas de caráter variável, cujas magnitudes dependem essencialmente do $\mathrm{pH}$ e da força iônica da solução que se encontra em 
contato com a fase sólida, bem como do estado de oxidação dos cátions e ânions predominantes nessa solução, conforme demonstrado por Raij \& Peech (1972). Uma excelente revisão sobre o assunto é apresentada por Bolan et al. (1999).

Mais recentemente, a avaliação de cargas de caráter permanente vem sendo realizada em solos das regiões tropicais (Weber, 2000; Chorover \& Sposito, 1995). Nesses trabalhos, tem-se utilizado o método da adsorção de césio proposto por Anderson \& Sposito (1991) e que se baseia na elevada afinidade que esse íon apresenta pelos sítios de carga com caráter permanente (Hird et al, 1996; Maes et al., 1999). Embora esse método apresente resultados satisfatórios, algumas vezes há uma aparente superestimativa das cargas permanentes presentes nos solos face àfalta de associação entre os resultados obtidos e a mineralogia dos solos avaliados (Fontes \& Sposito, 1995). Nesse sentido, e assim como destacado por Chorover et al. (1999), é importante a realização de pesquisas que permitam a contrastação dos atributos mineralógicos dos solos com a magnitude das cargas permanentes estimadas com 0 método da adsorção de césio.

Outro atributo eletroquímico de grande importância para os solos das regiões de clima tropical é a capacidade de troca aniônica (CTA). Ao contrário da capacidade de troca catiônica, poucos foram os avanços em relação a uma melhor caracterização das relações existentes entre esse atributo e a mineralogia da fração argila dos solos tropicais. Embora os óxidos apresentem destacado papel na retenção de ânions, pouco se conhece acerca da contribuição relativa de cada óxido para a intensidade da CTA. A maioria das informações relativas a esse atributo diz respeito ao seu papel na diminuição da lixiviação de ânions (Qafoku \& Sumner, 2001; Ludwig et al., 2001; Rasiah \& Armour, 2001).

\subsection{Adsorção e dessorção de sulfato}

\subsubsection{Adsorção de sulfato}

O íon sulfato é a principal forma inorgânica de enxofre presente no solo em condições aeróbicas e corresponde à principal forma do referido elemento absorvida pelas plantas. As interações do sulfato com a fase sólida do solo exercem influência 
sobre a sua mobilidade no perfil e sob a sua fitodisponibilidade. De fato, Barrow (1969) verificou relação inversa entre a velocidade de absorção radicular de sulfato por gramíneas e a capacidade de adsorção desse íon por solos australianos. Ainda em relação à disponibilidade de enxofre às plantas, observa-se que esse fenômeno pode influenciar também a eficiência dos extratores utilizados para a avaliação do enxofre disponível. Recentemente, Ribeiro et al. (2001) observaram que em solos brasileiros com menor capacidade de retenção de sulfato, a disponibilidade de enxofre foi mais bem avaliada com o uso da solução de $\mathrm{CaCl}_{2} 0,01 \mathrm{~mol} \mathrm{~L}^{-1}$; por outro lado, nos solos que adsorveram mais sulfato, o uso do extrator $\mathrm{NH}_{4} \mathrm{OAc} 0,5$ mol L ${ }^{-1}+\mathrm{HOAc} 0,25$ $\mathrm{mol} \mathrm{L}^{-1}$ proporcionou uma melhor predição da fitodisponibilidade de enxofre.

Além de seu efeito direto na fitodisponibilidade de enxofre, a adsorção de sulfato desempenha também importante papel na manutenção de cátions na região de influência das raízes. Considerando-se que para que um cátion possa apresentar movimentação vertical no solo é necessária a presença de ânions acompanhantes (Raij, 1988), a movimentação descente de sulfato no perfil poderá ter como conseqüência a lixiviação de bases trocáveis (Singh et al., 1980).

Uma das motivações observadas para a caracterização da capacidade adsortiva de sulfato dos solos das regiões altamente industrializadas está ligada à ocorrência de chuvas ácidas, as quais apresentam sulfato em sua composição. A contínua ocorrência dessas chuvas pode promover incrementos significativos nos teores de sulfato dos solos e em conseqüência favorecer a lixiviação de cátions (Huete \& Mc Coll, 1984; Patil et al., 1989; Comfort et al., 1992; Alewell et al., 1997).

Nas regiões agrícolas, uma das principais formas de adição de sulfato ao solo consiste no manejo químico do mesmo, por meio de adubações e correções, visando à melhoria de sua fertilidade. Nesse contexto, deve-se destacar a utilização do gesso agrícola, um subproduto da indústria de ácido fosfórico, que apresenta em sua composição cerca de 95\% de sulfato de cálcio dihidratado (Raij, 1988). Vários são os relatos de lixiviação de cátions nutrientes em decorrência da aplicação de gesso em solos: Quaggio et al. (1982); Pavan et al. (1984); Alva \& Gascho (1991); Toma et al. (1999); Wang et al. (1999). Percebe-se, portanto, a importância de um melhor entendimento dos mecanismos e fatores envolvidos com a adsorção de sulfato. A realização de pesquisas nessa área com maior grau de detalhamento poderá fornecer 
informações bastante úteis para um adequado manejo desse insumo nos solos das regiões tropicais.

\subsubsection{Fatores que afetam a adsorção de sulfato}

Tendo em vista a importância do fenômeno da adsorção de sulfato, torna-se necessário considerar os fatores que o afetam. Dentre esses fatores, podem ser citados a natureza da fase sólida inorgânica do solo, o pH, o teor de matéria orgânica, e a presença de outros íons.

Estudos realizados com minerais isolados e solos demonstram que a presença de óxidos de ferro e de alumínio intensifica a adsorção de sulfato pelo solo (Aylmore et al., 1967). Por outro lado, essa apresenta menor expressão quando há predominância de caulinita (Aylmore et al., 1967) ou argilominerais do tipo 2:1 (Berg \& Thomas, 1959) no sistema Essas constatações apresentam relação direta com os mecanismos propostos para a adsorção de sulfato como será tratado adiante.

Em relação ao pH do solo, há um consenso de que a adsorção aumenta com a diminuição da magnitude desse atributo eletroquímico (Ensminger, 1954; Kamprath et al, 1956, Marsh et al., 1987, Zhang \& Yu, 1997). Tal fato estaria, à primeira vista, associado ao aumento na densidade superficial de cargas positivas decorrente do abaixamento do $\mathrm{pH}$ da solução.

A influência da matéria orgânica sobre a adsorção de sulfato pode ocorrer de duas maneiras opostas. De um lado, há a possibilidade de competição direta de ânions orgânicos por sítios de adsorção. Em geral, a grande maioria dos trabalhos demonstra que tais íons são via de regra adsorvidos preferencialmente ao sulfato pelos componentes da fase sólida (Ali \& Dzombak, 1995; Kaiser \& Zech, 1996; Martinez et al., 1998; Liu et al., 1999). Por outro lado, o efeito inibidor da matéria orgânica sobre a cristalização de óxidos (Schwertmann, 1985) faz com que haja a manutenção de formas menos cristalinas desses óxidos, que apresentam capacidade adsortiva reconhecidamente maior que as cristalinas (Bohn et al., 1979).

A presença de outros íons pode também exercer a influência na retenção de sulfato. Bolan et al. (1993) e Marcano-Martinez \& McBride (1989) verificaram um incremento na adsorção de sulfato por solos neozelandeses e brasileiros, 
respectivamente, associado à presença de cálcio; contudo, os resultados experimentais que serviriam de suporte para a interpretação dos mecanismos envolvidos não foram similares. Desse modo, de acordo com as considerações de Bolan et al. (1993) o incremento na adsorção de sulfato em solos oxídicos na presença de cálcio é devido a uma possível adsorção específica do cátion e conseqüente aumento nas cargas positivas de superfície; já, para Marcano-Martinez \& McBride (1989), a coadsorção de $\mathrm{Ca}^{2+}$ e $\mathrm{SO}_{4}{ }^{2-}$ em superfícies com carga líquida nula seria a responsável pela maior adsorção do ânion verificada na presença de $\mathrm{Ca}^{2+}$. Agbenin (1997), por outro lado, não observou efeito da natureza do cátion sobre a adsorção de sulfato por solos nigerianos.

Ao contrário do mencionado efeito positivo do cálcio, a competição exercida pelo fosfato é mais bem documentada e unânime quanto ao efeito negativo que a presença desse ânion exerce sobre a adsorção de sulfato (Esminger, 1954; Kamprath, 1956, Bolan et al., 1988; Geelhoed et al.; 1997).

Depreende-se, portanto, com base nas informações apresentadas, que as camadas superficiais dos solos agrícolas não reúnem condições favoráveis para a adsorção de sulfato, haja vista o necessário manejo químico das mesmas por meio de calagens e fosfatagens ou a adoção de práticas que visam ao aumento do teor de matéria orgânica na mesma. Aumento na lixiviação de sulfato em decorrência das práticas acima mencionadas foi observado por Dynia \& Camargo (1995) e por Motavalli et al. (1993) em Latossolos da região centro-oeste do Brasil. Em conseqüência disso, torna-se mais interessante a utilização, em estudos de adsorção e dessorção de sulfato, de amostras de solos coletadas em camadas subsuperficiais quando tais estudos visam àidentificação de minerais ou óxidos mal cristalizados mais diretamente associados aos referidos fenômenos.

\subsubsection{Mecanismos de adsorção de sulfato}

O mecanismo de adsorção de sulfato por solos é um tema controvertido. Enquanto alguns trabalhos destacam a adsorção eletrostática de íon, outros apresentam evidências da ocorrência de adsorção específica. Contudo, pode-se dizer 
que as interpretações dadas para certos resultados de pesquisa são, na verdade, complementares.

No trabalho de Marsh et al. (1987), realizado com solos que continham materiais alofânicos, foi observada uma excelente relação linear entre a quantidade de cargas positivas de superfície e a quantidade de sulfato adsorvida. À primeira vista, esse resultado poderia sugerir de forma contundente que a adsorção de sulfato consiste em um mecanismo de atração eletrostática. Posteriormente, Zhang \& Yu (1997) apresentaram um interessante conjunto de dados relativos às quantidades de sulfato adsorvidas e à conseqüentes liberações de hidroxilas e variações da carga líquida superficial em solos brasileiros e chineses. Com base na proporção de hidroxilas liberadas para o número de íons $\mathrm{SO}_{4}{ }^{2-}$ adsorvidos e na variação da carga líquida para cada unidade de sulfato retido, os autores chegaram àconclusão de que a troca de ligantes era o processo responsável pela adsorção de sulfato naqueles solos.

Outro aspecto a ser considerado é o efeito negativo do pH sobre a adsorção de sulfato. Sabe-se que ao aumento do $\mathrm{pH}$ em solos com cargas variáveis implica em uma maior manifestação de cargas de natureza negativa, que seria responsável por uma menor adsorção eletrostática de sulfato; contudo, ao considerar-se a troca de ligantes, há a argumentação de que grupos $-\mathrm{OH}$, quando protonados, são mais facilmente substituídos por íons sulfato e que, por essa razão, a adsorção é mais intensa em condições mais ácidas (Zhang \& Yu, 1997).

Zhang \& Sparks (1990) ao demonstrarem, por meio da associação de modelos de complexação de superfície e estudos de cinética de adsorção/dessorção, que suas observações experimentais eram compatíveis com a ocorrência de interações eletrostáticas entre os íons sulfato e uma goethita sintética, mencionaram que o aumento de $\mathrm{pH}$ decorrente da adsorção de sulfato não era devido àtransferência de hidroxilas da superfície para a solução em virtude da troca das mesmas por íons sulfato, mas provenientes da hidrólise da água ou da protonação do íon sulfato, fenômenos esses envolvidos com o mecanismo de adsorção. Já, Zhang et al. (1989) atribuem ao deslocamento de hidroxilas de superfície pelo íon sulfato o maior valor de $\mathrm{pH}$ da solução observado em estudos de adsorção do referido íon em um solo intemperizado da China. 
Além dos aspectos mencionados, a adsorção de sulfato pode apresentar dependência da força iônica da solução, à semelhança do observado para íons reconhecidamente adsorvidos por interações eletrostáticas (Bolan et al., 1986; Courchesne ,1991). Contudo, há casos em que variações na força iônica da solução não se refletem em alterações nas quantidades adsorvidas de sulfato, a exemplo do verificado por Agbenin (1997).

Dada a complexidade apresentada pelo solo quanto à sua composição e as inúmeras interações que podem ocorrer nesse sistema, pode-se concluir que a elucidação do real mecanismo associado à adsorção de sulfato não é uma tarefa de simples execução, podendo-se considerá-la como quase impossível. Dessa forma, mesmo que os resultados possam apresentar discrepâncias em relação aos sistemas naturais, é necessário que estudos dessa natureza sejam realizados com sistemas mais simples e com características bem controladas. Foram essas condições que permitiram a Peak et al. (1999) demonstrarem que a adsorção de sulfato pela goethita ocorre por meio de ambos os tipos de interação, ou seja, por adsorção específica e não específica e que o predomínio de um ou de outro mecanismo apresenta dependência do pH e da força iônica da solução.

\subsubsection{Isotermas de adsorção}

Bolland et al. (1996) consideram que as duas formas mais comuns de se avaliar a capacidade de adsorção de fosfato dos solos são o estudo das isotermas e a determinação de propriedades do solo que apresentam íntima e consistente correlação com o fenômeno, afirmação esta que pode ser perfeitamente estendida à adsorção de sulfato. Essa abordagem é freqüentemente utilizada tendo por objetivo principal a melhor compreensão e predição do fenômeno, a partir de determinações mais simples. As correlações assim obtidas não implicam, obrigatoriamente, em uma relação causaefeito, mas fornecem informações valiosas e de considerável utilidade, mesmo que devam ser consideradas como simples referências ou como tendências verificadas.

O método mais adequado para a efetiva avaliação do fenômeno de adsorção de sulfato é o que contempla as curvas ou isotermas de adsorção, apesar de sua obtenção ser menos simples que outras estimativas da capacidade adsortiva do solo, 
como, por exemplo, o enxofre remanescente (Alvarez V. et al, 1983). O método das isotermas consiste na agitação de subamostras de solo com soluções contendo quantidades crescentes de sulfato, medindo-se posteriormente a concentração do íon que permanece em solução e calculando-se, por diferença do valor adicionado, a quantidade adsorvida. Finalmente, as quantidades adsorvidas dos íons e suas concentrações remanescentes são utilizadas no ajustamento de equações cujos parâmetros podem apresentar significado físico e que, portanto, podem ser utilizados como índices de adsorção.

A maior parte dessas equações é teórica ou referente a outros fenômenos de adsorção, embora sua aplicação e as possibilidades de uso na Ciência do Solo sejam por demais reconhecidas. Goldberg \& Sposito (1984) destacam a natureza empírica dessas equações, recomendando que sejam consideradas estritamente como tal e que sua utilização seja concebida unicamente como um procedimento de ajuste de curvas.

Essas equações, denominadas isotermas de adsorção, têm sido largamente utilizadas em estudos de adsorção aniônica. Várias são as equações propostas para o ajuste dos dados de adsorção; dentre elas, destacam-se as de Langmuir e de Freundlich.

A equação de Langmuir foi utilizada pela primeira vez por Olsen \& Watanabe (1957) para descrever a adsorção de fosfato. Esta costuma ser mais freqüentemente preferida pelos pesquisadores, uma vez que seus parâmetros permitem a estimativa da capacidade máxima de adsorção e da afinidade do adsorvente pelo adsorvato.

As referências relacionadas com o uso da equação de Langmuir são, em sua maioria, associadas à adsorção de fosfato. Owusu-Bennoah et al. (1997) observaram que, embora a equação de Langmuir tenha apresentado bom ajuste aos dados experimentais, as quantidades estimadas pelo referido modelo tendiam a ser bem maiores que as determinadas para as maiores concentrações de equilíbrio, indicando que a aplicação dessa equação deveria ser considerada restrita a determinadas concentrações. Semelhantes considerações foram apresentadas por Udo \& Uzu (1972), os quais sugerem que os valores determinados com a utilização do modelo para as maiores concentrações devem ser considerados uma extrapolação e que, em alguns casos, podem ser de utilização questionável. Quang et al. (1996) utilizaram essa justificativa para usar uma equação de Langmuir com duas inclinações, 
representando dois sítios de adsorção, considerados não como posições de capacidades adsortivas uniformes e sim que incluem larga população de diferentes sítios de adsorção.

Entre os que descrevem as limitações da equação de Langmuir, Harter (1984) parece ser um dos mais contundentes, questionando inclusive a utilização da equação de duas superfícies. $O$ autor critica principalmente o procedimento de linearização normalmente adotado na ampla maioria dos trabalhos científicos, afirmando que ajustar uma equação em que ambos os membros apresentam uma mesma variável reduz substancialmente a variabilidade dos dados, dando origem a elevados coeficientes de determinação para as equações lineares ajustadas. Outro problema, de ordem metodológica, diz respeito a erros da ordem de $50 \%$ ou mais, na estimativa da capacidade máxima de adsorção, quando esse valor é obtido por extrapolação de uma curva constituída de dados que, nela não se aproximam da região dessa estimativa (Taylor et al., 1996).

Para Barrow (1983), embora seja de ampla utilização e aceitação, a equação de Langmuir raramente fornece uma descrição realística de fenômeno, sendo melhor opção a utilização da equação de Freundlich.

A equação de Freundlich é a mais antiga das isotermas utilizadas em estudos de adsorção aniônica (Barrow, 1978) e caracteriza-se por ser puramente empírica. Apesar de seus parâmetros não possuírem significado físico, observa-se que os mesmos apresentam correlação com a capacidade máxima de adsorção e com a afinidade da fase sólida pelo adsorvato estimados pelos parâmetros da isoterma de Langmuir (Mead, 1981).

Chen et al. (1999) questionam a utilização do parâmetro da equação de Freundlich associado à capacidade de adsorção apresentada pela fase sólida em virtude de problemas de comparação de unidades. Segundo esses autores, considerando-se que a equação de Freundlich é dada por $q=k c^{1 / n}$, em que $k$ e $n$ são os parâmetros ajustáveis, q é a quantidade adsorvida e c a concentração do íon na solução de equilíbrio, pode-se notar que a unidade do parâmetro $k$ dependerá do valor do parâmetro $\mathrm{n}$, o qual é adimensional. Em outras palavras, considerando-se a igualdade do parâmetro $\mathrm{k}$ àrelação $\mathrm{q} / \mathrm{c}^{1 / \mathrm{n}}$, verifica-se que a unidade de $\mathrm{k}$ será igual a unidade de q dividida pela unidade de $\mathrm{c}$ apenas quando $\mathrm{n}$ for igual a 1 . Desse modo, e 
considerando-se as unidades utilizadas no presente trabalho verifica-se que 0 parâmetro $\mathrm{k}$, para $\mathrm{n}$ igual a 1 , seria expresso em $\mathrm{mL} \mathrm{g}^{-1}$. Contudo, na maioria das vezes o valor do parâmetro $n$ é diferente da unidade; assim sendo e considerando-se novamente as unidades utilizadas no presente trabalho, constata-se que o parâmetro $\mathrm{k}$ seria expresso com a seguinte unidade: $\mu \mathrm{g}^{(1-1 / n)} \mathrm{g}^{-1} \mathrm{~mL}^{1 / n}$, que se reduz para $\mathrm{mL}^{-1}$ quando $\mathrm{n}$ é igual a 1.

Com base nessas considerações, verifica-se que a utilização do parâmetro k da equação de Freundlich para a comparação de capacidades adsortivas de diferentes adsorventes para um mesmo íon é, ao menos, a rigor inválida, haja vista que, na maioria dos ajustamentos, o valor do parâmetro n é diferente de 1 . Na literatura podem ser encontrados trabalhos como os de Hasset et al. (1981), Xue \& Selim (1995) e Comfort et al. (1995) que utilizaram as unidades $\mathrm{mL} \mathrm{g}^{-1}$ ou $\mathrm{L} \mathrm{kg}^{-1}$ para a expressão de k e outros como o de Houng \& Lee (1998) em que o referido parâmetro foi expresso em termos de mmol $\mathrm{kg}^{-1}$. Em todos os trabalhos supracitados, o parâmetro $\mathrm{n}$ foi diferente da unidade.

Com o objetivo de explorar a utilidade do parâmetro k para fins comparativos, Chen et al. (1999) propuseram o uso de uma variável uniformizadora calculada por meio da expressão $k_{u}=k / c^{(n-1) / n}$. Desse modo, as comparações podem ser feitas a partir de valores de $k_{u}$ calculados para um valor comum de concentração de equilíbrio, dentro do conjunto de isotermas a ser avaliado. Deve-se ressaltar ainda que, com esse procedimento, todos os valores a serem utilizados nas comparações e/ou estudos de correlação apresentarão a mesma unidade.

\subsubsection{Dessorção de sulfato}

Relativamente escassas são as informações relacionadas à dessorção de sulfato. Embora para a maioria dos trabalhos o método de avaliação seja semelhante e a dessorção seja expressa em termos de percentual dessorvido em relação ao sulfato previamente adsorvido, uma comparação de resultados torna-se dificultada haja vista a variação existente quanto ao extrator utilizado. Bornemisza \& Llanos (1967) utilizaram água como extrator; Couto et al. (1978) avaliaram a dessorção de sulfato 
utilizando solução de $\mathrm{NH}_{4} \mathrm{NO}_{3}$ 0,05 mol L-1 ao passo que Agbenin (1987) utilizou a solução de $\mathrm{KCl} 1 \mathrm{~mol} \mathrm{~L}^{-1}$ para a extração do sulfato adsorvido.

Ao analisar-se os fatores que interferem na dessorção de sulfato, pode-se perceber alguma relação com os mecanismos de adsorção. Curtin \& Syers (1990) verificaram que a dessorção de sulfato foi menor quando, para uma mesma força iônica, a solução salina extratora apresentava $\mathrm{Ca}^{2+}$ ao invés de $\mathrm{Na}^{+}$em sua constituição; do mesmo modo, o aumento da força iônica da solução mostrou-se como capaz de intensificar a dessorção de sulfato. 


\section{MATERIAL E MÉTODOS}

\subsection{Solos estudados}

Os estudos do presente trabalho foram realizados utilizando-se amostras coletadas na camada subsuperficial de solos situados em diferentes localidades do Estado de São Paulo. A classificação, localização, profundidade de amostragem e o material de origem dos solos estudados são apresentados na Tabela 1.

\subsection{Análises efetuadas}

\subsubsection{Tratamentos prévios}

As amostras de terra foram destorroadas, secas ao ar e passadas em peneira com $2 \mathrm{~mm}$ de abertura de malha obtendo-se a terra fina seca ao ar (TFSA).

\subsubsection{Análises físicas}

A granulometria foi o único atributo físico avaliado nas amostras estudadas. Essa avaliação foi realizada em triplicatas empregando-se o método da pipeta, sendo as amostras submetidas à dispersão química com solução de $\mathrm{NaOH} 0,1 \mathrm{~mol} \mathrm{~L}^{-1}$ e à dispersão mecânica em agitador tipo "stirrer" (Embrapa, 1997).

\subsubsection{Análises químicas}

Foram realizadas as seguintes análises químicas: 
Tabela 1. Classificação, localização, profundidade de amostragem e material de origem dos solos estudados.

\begin{tabular}{|c|c|c|c|c|c|}
\hline Núm. & Classificação brasileira & Soil Taxonomy & Local de coleta & Prof. (cm) & Material de origem \\
\hline 1 & Latossolo Vermelho Acriférrico (LVwf) & Rhodic Acrudox & Ribeirão Preto & $100-140$ & Basalto \\
\hline 2 & Latossolo Vermelho Eutroférrico (LVef) & Rhodic Eutrudox & Iracemápolis & $100-110$ & Basalto \\
\hline 3 & Latossolo Vermelho Distroférrico (LVdf) & Rhodic Hapludox & Luís Antonio & $80-100$ & Basalto \\
\hline 4 & Latossolo Vermelho Acriférrico (LVwf) & Rhodic Acrudox & Luís Antonio & $150-170$ & Basalto \\
\hline 5 & Latossolo Amarelo Ácrico (LAw) & Xanthic Acrustox & Guaíra & $100-130$ & Basalto \\
\hline 6 & Latossolo Vermelho Distrófico (LVd) & Typic Hapludox & Piracicaba & $100-110$ & Folhelho \\
\hline 7 & Latossolo Vermelho-Amarelo Distrófico (LVAd) & Typic Hapludox & Piracicaba & $100-110$ & Arenito \\
\hline 8 & Latossolo Vermelho-Amarelo Distrófico (LVAd) & Typic Hapludox & São Carlos & $80-100$ & Arenito \\
\hline 9 & Nitossolo Vermelho Eutroférrico (NVef) & Typic Hapludalf & Piracicaba & $30-40$ & Diabásio \\
\hline 10 & Argissolo Vermelho-Amarelo Distrófico (PVAd) & Typic Hapludult & Pindorama & $100-120$ & Arenito \\
\hline 11 & Argissolo Vermelho-Amarelo Distrófico (PVAd) & Typic Hapludult & Vera Cruz & $100-120$ & Arenito \\
\hline 12 & Argissolo Vermelho Eutrófico (PVe) & Typic Hapludult & Rio Claro & $70-80$ & Folhelho \\
\hline 13 & Argissolo Vermelho Distrófico (PVd) & Typic Hapludult & Piracicaba & $100-110$ & Basalto \\
\hline 14 & Argissolo Vermelho-Amarelo Eutrófico (PVAe) & Typic Hapludult & São Pedro & $20-35$ & Folhelho \\
\hline 15 & Neossolo Quartzarênico Órtico (RQo) & Typic Quatzipsamment & São Pedro & $80-100$ & Arenito \\
\hline
\end{tabular}




\subsubsection{Matéria orgânica}

O teor de matéria orgânica das amostras foi determinado utilizando-se o método de Walkley-Black (Cantarella et al., 2001).

\subsubsection{Complexo sortivo}

Os teores trocáveis de $\mathrm{K}^{+}, \mathrm{Ca}^{2+} \mathrm{e} \mathrm{Mg}^{2+}$ foram obtidos mediante extração com resina trocadora de íons e determinação por meio de fotometria de emissão de chama $\left(\mathrm{K}^{+}\right)$e espectrofotometria de absorção atômica $\left(\mathrm{Ca}^{2+} \mathrm{e} \mathrm{Mg}^{2+}\right)$ (Raij \& Quaggio, 2001). $\mathrm{O}$ $\mathrm{Al}^{3+}$ trocável foi quantificado por meio de extração com solução de $\mathrm{KCl} 1 \mathrm{~mol} \mathrm{~L}^{-1} \mathrm{e}$ determinação titulométrica com solução de $\mathrm{NaOH} 0,025 \mathrm{~mol} \mathrm{~L}^{-1}$, utilizando fenolftaleína como indicador (Cantarella et al., 2001). A acidez potencial $(\mathrm{H}+\mathrm{Al}$ ) foi determinada empregando-se o método do pH SMP (Quaggio \& Raij, 2001). Os teores de fósforo foram obtidos por extração com resina trocadora de íons (Raij \& Quaggio, 2001) e determinação colorimétrica empregando-se o método de Murphy \& Riley (1962). A determinação dos teores de sulfato adsorvido e solúvel foi realizada mediante extração com solução de $\mathrm{Ca}\left(\mathrm{H}_{2} \mathrm{PO}_{4}\right)_{2} \cdot \mathrm{H}_{2} \mathrm{O} \quad 0,01 \mathrm{~mol} \mathrm{~L}^{-1}$ e quantificação turbidimétrica com o emprego do método do cloreto de bário em pó (Cantarella \& Prochnow, 2001).

A partir dos teores de $\mathrm{K}, \mathrm{Ca}$ e Mg, foi calculada a soma de bases (SB) ; a capacidade de troca cationica potencial $(\mathrm{T})$ foi calculada somando-se os teores dos cátions trocáveis e a acidez potencial. As saturações por $\mathrm{Al}^{3+}$ (m\%) e por bases $(\mathrm{V} \%)$ foram calculadas dividindo-se, respectivamente, os teores de $\mathrm{Al}^{3+}$ e a soma de bases pelo valor da capacidade de troca catiônica potencial.

\subsubsection{Fósforo remanescente}

A determinação do fósforo remanescente (P-rem) consistiu na agitação por uma hora de subamostras de TFSA com solução de $\mathrm{CaCl}_{2} 0,01 \mathrm{~mol} \mathrm{~L}^{-1}$ contendo $60 \mu \mathrm{g} \mathrm{mL}^{-1}$ de fósforo (solo:solução $=1: 10$ ), na subseqüente filtragem das suspensões e na quantificação do fósforo, que permaneceu em solução empregando-se o método colorimétrico (Alvarez V. \& Fonseca, 1990). 


\subsubsection{Ataques sulfúrico e alcalino}

Os ataques sulfúrico e alcalino foram realizados em subamostras de TFSA segundo Embrapa (1997). Os teores de ferro e alumínio no extrato sulfúrico foram determinados por espectrofotometria de absorção atômica; a determinação das concentrações de silício nos extratos alcalinos foi efetuada empregando-se o método colorimétrico. A partir dos resultados analíticos, foram calculados os índices de intemperismo $\mathrm{Ki}$ e $\mathrm{Kr}$, dados por:

$$
\begin{aligned}
& \mathrm{Ki}=1,7 \frac{\mathrm{SiO}_{2}}{\mathrm{Al}_{2} \mathrm{O}_{3}} \\
& \mathrm{Kr}=1,7 \frac{\mathrm{SiO}_{2}}{\left(\mathrm{Al}_{2} \mathrm{O}_{3}+0,64 \mathrm{Fe}_{2} \mathrm{O}_{3}\right)}
\end{aligned}
$$

em que $\mathrm{SiO}_{2}, \mathrm{Al}_{2} \mathrm{O}_{3}$ e $\mathrm{Fe}_{2} \mathrm{O}_{3}$ correspondem, respectivamente, aos teores de $\mathrm{Si}, \mathrm{Al}$ e $\mathrm{Fe}$ $\left(\mathrm{g} \mathrm{kg}^{-1}\right)$ expressos sob a forma de óxidos.

\subsubsection{Ferro e alumínio vinculados aos óxidos cristalinos e mal cristalizados}

Os teores de $\mathrm{Fe} \mathrm{e} \mathrm{Al,} \mathrm{vinculados} \mathrm{aos} \mathrm{óxidos} \mathrm{cristalinos} \mathrm{e} \mathrm{de} \mathrm{baixa} \mathrm{cristalinidade,}$ foram determinados em triplicatas na TFSA e na fração argila, empregando-se uma adaptação do método de Holmgren (1967) proposta por Buurman et al. (1996); contudo, ao invés de uma única agitação de 16 horas da subamostra de TFSA ou fração argila com a solução de ditionito-citrato de sódio (DC) àtemperatura ambiente, foram realizadas cinco extrações sucessivas com um período total de agitação de 80 horas. Tal procedimento foi adotado devido aos altos teores de Fe contidos na maioria das amostras. Após cada agitação, as suspensões foram centrifugadas e filtradas, sendo as soluções obtidas coletadas em balões volumétricos de $100 \mathrm{~mL}$ de capacidade, cujos volumes foram completados com solução de ditionito-citrato ao final 
da etapa de extração. As concentrações de $\mathrm{Fe}$ e $\mathrm{Al}$ nos extratos ( $\mathrm{Fe}_{\mathrm{DC}}$ e $\left.\mathrm{Al} \mathrm{D}_{\mathrm{DC}}\right)$ foram quantificadas por espectrofotometria de absorção atômica.

\subsubsection{Ferro e alumínio vinculados aos óxidos mal cristalizados}

A determinação dos teores de $\mathrm{Fe}$ e $\mathrm{Al}$ vinculados aos óxidos mal cristalizados foi realizada em triplicatas na TFSA e na fração argila. A extração dos referidos elementos foi realizada por meio da agitação das subamostras de TFSA e argila com solução ácida de oxalato de amônio, em ausência de luz, durante 4 horas (Buurman et al., 1996). A quantificação das concentrações de $\mathrm{Fe}$ e Al nos extratos ( $\mathrm{Fe}_{\text {OXA }}$ e $\mathrm{Al}_{\text {OXA }}$ ) foi efetuada por espectrofotometria de absorção atômica.

\subsubsection{Análises eletroquímicas}

\subsubsection{1 pH}

Foram determinados os valores de $\mathrm{pH}$ em suspensões de TFSA e água ( $\mathrm{pH} \mathrm{H} \mathrm{H}_{2} \mathrm{O}$ ), TFSA e solução de $\mathrm{KCl} 1 \mathrm{~mol} \mathrm{~L}^{-1}(\mathrm{pH} \mathrm{KCl})$ e de TFSA e solução de $\mathrm{CaCl}_{2}$ $0,01 \mathrm{~mol} \mathrm{~L}^{-1}\left(\mathrm{pH} \mathrm{CaCl}_{2}\right)$ na proporção sólido-água ou sólido-solução de 1:2,5 (Embrapa, 1997). Adicionalmente, efetuou-se a determinação dos valores de $\mathrm{pH}$ em solução de $\mathrm{NaF} 1 \mathrm{~mol} \mathrm{~L}^{-1}$ (pH NaF), na proporção sólido-solução de 1:40, após uma 1 hora de agitação (Bolland et al., 1996). Além das determinações efetuadas na TFSA, os valores de $\mathrm{pH} \mathrm{NaF}$ foram também medidos nas frações argila total e argila desferrificada. Todas as avaliações foram realizadas em triplicatas.

A partir dos valores de $\mathrm{pH}$ medidos em solução de $\mathrm{KCl} 1 \mathrm{~mol} \mathrm{~L}^{-1} \mathrm{e}$ em água, foram calculados os valores de $\Delta \mathrm{pH}$, índice dado por: $\Delta \mathrm{pH}=\mathrm{pH} \mathrm{KCl}-\mathrm{pH} \mathrm{H}_{2} \mathrm{O}$ (Mekaru \& Uehara, 1972).

\subsubsection{Ponto de efeito salino nulo}

O ponto de efeito salino nulo (PESN) foi utilizado como estimativa do ponto de carga zero (PCZ) das amostras estudadas e determinado com o emprego do método 
da titulação potenciométrica utilizado por Raij \& Peech (1972) com modificações propostas por Costa et al. (1984).

Para a obtenção dos dados de titulação potenciométrica, procedeu-se, inicialmente, à realização de estudos preliminares com o objetivo de se definir a amplitude das adições de ácido e base que deveriam ser realizadas de modo a possibilitar que o $\mathrm{PESN}$ estivesse compreendido entre os valores de $\mathrm{pH}$ atingidos pelas suspensões constituídas por subamostras de TFSA e solução salina na proporção 1:4 (sólido-solução). Para tanto, calculou-se a estimativa do PCZ de cada amostra utilizando-se a equação proposta por Keng \& Uehara (1974), a qual é dada por : $\mathrm{PCZ}=2 \mathrm{pH} \mathrm{KCl}-\mathrm{pH} \mathrm{H}_{2} \mathrm{O}$, e determinou-se $0 \mathrm{pH}$ que as suspensões sólido-solução salina atingiram 24 horas após a adição à mesmas de $0,5 \mathrm{~mL}$ de solução de $\mathrm{HCl} 0,4$ $\mathrm{mol} \mathrm{L}^{-1}$ e $0,5 \mathrm{~mL}$ de solução de $\mathrm{NaOH} 0,1 \mathrm{~mol} \mathrm{~L}^{-1}$. Considerando-se que foram empregadas soluções salinas constituídas por $\mathrm{NaCl}$ nas concentrações de 0,$1 ; 0,01 \mathrm{e}$ $0,001 \mathrm{~mol} \mathrm{~L}^{-1}$, os testes envolvendo a adição de ácido e base às suspensões foram efetuados apenas nas suspensões elaboradas com a solução de $\mathrm{NaCl} 0,001 \mathrm{~mol} \mathrm{~L}^{-1}$, em virtude de apresentarem maior variação de $\mathrm{pH}$ que as preparadas com as demais soluções salinas para uma mesma quantidade de ácido ou base adicionada.

Uma vez conhecidas as estimativas do PCZ e as amplitudes de variação de $\mathrm{pH}$ das suspensões em decorrência de adições de ácido e base, os valores de PESN foram determinados em triplicatas, adotando-se o seguinte procedimento para a obtenção dos dados de titulação potenciométrica:

- subamostras de $4 \mathrm{~g}$ TFSA foram transferidas para copos plásticos de $50 \mathrm{~mL}$ de capacidade, totalizando 18 unidades por solo;

- dividiram-se os recipientes em três grupos de seis; em um deles, cada copo recebeu $20 \mathrm{~mL}$ de solução de $\mathrm{NaCl} 0,1 \mathrm{~mol} \mathrm{~L}^{-1}$; em outro $20 \mathrm{~mL}$ de solução de $\mathrm{NaCl} 0,01 \mathrm{~mol} \mathrm{~L}^{-1}$ e no outro, $20 \mathrm{~mL}$ de solução de $\mathrm{NaCl} 0,001 \mathrm{~mol} \mathrm{~L}^{-1}$;

- adicionaram-se aos recipientes de cada série volumes de $\mathrm{HCl} 0,4 \mathrm{~mol} \mathrm{~L}^{-1}$ e de $\mathrm{NaOH}$ $0,1 \mathrm{~mol} \mathrm{~L}^{-1}$, que variaram entre 0 e $0,5 \mathrm{~mL}$;

- agitaram-se as suspensões que, em seguida, permaneceram em repouso por 24 horas; 
- agitaram-se novamente as suspensões e 30 minutos depois efetuou-se a determinação do $\mathrm{pH}$ das mesmas.

Visando-se conferir maior rapidez ao tratamento dos dados de titulação potenciométrica para a determinação do PESN e, ao mesmo tempo, eliminar a subjetividade do método gráfico convencional normalmente utilizado para esse fim, desenvolveu-se um procedimento de cálculo para a determinação do referido atributo eletroquímico. Esse procedimento foi em seguida automatizado, elaborando-se um programa computacional por meio da utilização do sistema de desenvolvimento de aplicativos Delphi Borland Standard 3.0 $0^{\boxplus}$.

\subsubsection{Capacidades de troca catiônica e aniônica (CTC e CTA)}

\subsection{Capacidade de troca catiônica}

A capacidade de troca catiônica efetiva das amostras estudadas foi determinada em triplicatas utilizando-se o método de Gillman (1979), que permite a determinação da CTC sem a distinção do caráter das cargas negativas das quais ela deriva. Adicionalmente, a CTC das amostras foi avaliada pelo método da adsorção de césio (Zelazny et al., 1996), o qual possibilita a quantificação da CTC devida æ̀ cargas negativas de caráter permanente e da fração devida à cargas negativas de caráter variável. As forças iônicas médias, na etapa de saturação do complexo sortivo, foram de $0,006 \mathrm{~mol} \mathrm{~L}^{-1}$ para o método de adsorção de bário (Gillman, 1979) e de $0,05 \mathrm{~mol} \mathrm{~L}^{-1}$ para o método da adsorção de césio.

\subsection{Capacidade de troca aniônica}

A capacidade de troca aniônica efetiva foi determinada empregando-se o método de Gillman (1979). Os teores de cloreto presentes nos extratos, que após as devidas correções correspondem àCTA efetiva das amostras, foram quantificados por 
meio de análise potenciométrica, utilizando-se um eletrodo seletivo acoplado a um potenciômetro Orion $720 A^{\circledR}$.

\subsubsection{Análises mineralógicas}

\subsubsection{Tratamento prévio das amostras}

Inicialmente, subamostras de TFSA foram submetidas ao tratamento com peróxido de hidrogênio a 30\%, sob aquecimento, para a remoção da matéria orgânica. Em seguida, os materiais resultantes foram secos em estufa mantida a $60^{\circ} \mathrm{C}$ e submetidos às dispersões química, com $\mathrm{NaOH} \mathrm{0,01} \mathrm{mol} \mathrm{L}^{-1}$, e mecânica em agitador do tipo "stirrer". A fração areia foi separada por peneiramento úmido e as frações silte e argila foram separadas por sedimentação com base no princípio da lei de Stokes (Embrapa, 1997). A fração argila, recolhida após sucessivos sifonamentos, foi submetida à floculação com a adição de quantidades estequiométricas de $\mathrm{HCl}$ às suspensões obtidas, lavada com água para a remoção dos sais formados, seca em estufa até peso constante, moída em almofariz e passada em peneira com $0,21 \mathrm{~mm}$ de abertura de malha.

\subsubsection{Estimativa dos teores de caulinita e gibbsita}

Os teores de caulinita e gibbsita foram semiquantificados por meio de análise térmica diferencial.

Submostras de fração argila foram inicialmente desferrificadas mediante 5 extrações sucessivas com solução de ditionito-citrato de sódio e, em seguida, saturadas com magnésio por meio de agitação com solução de $\mathrm{MgCl}_{2} 1 \mathrm{~mol} \mathrm{~L}^{-1}$. Uma vez saturadas, as amostras foram lavadas com água destilada, secas em estufa, moídas em almofariz e passadas em peneira de 0,21 $\mathrm{mm}$ para uniformização granulométrica.

As determinações foram realizadas em triplicata em um analisador térmico diferencial Shimadzu DSC $-50^{\circledR}$, sob atmosfera de $\mathrm{N}_{2}$ e com taxa de aquecimento de $10^{\circ} \mathrm{C} \min ^{-1}$. 
A análise dos termogramas foi realizada com o emprego do programa computacional TA-50WS, o que permitiu a determinação dos valores das temperaturas referentes aos picos de desidroxilação dos minerais e a avaliação analítica dos valores das áreas apresentadas por esses picos.

\subsubsection{Difratometria de raios $X$}

As análises mineralógicas por difratometria de raios $X(D R X)$ foram realizadas nas frações argila desferrificada e concentrada em óxidos de ferro.

\subsection{Fração argila desferrificada}

O preparo da fração argila das amostras avaliadas para a execução das análises por DRX no material desferrificado seguiu os procedimentos propostos por Jackson (1969). Desse modo, subamostras da fração argila de cada solo foram transferidas para tubos de centrífuga de $100 \mathrm{~mL}$ de capacidade e desferrificadas por meio de extrações com solução de ditionito-citrato-bicarbonato de sódio a quente. Em seguida, parte de cada subamostra foi saturada com potássio e parte, com magnésio. As suspensões obtidas foram sucessivamente lavadas com álcool etílico e acetona visando-se à eliminação do íon cloreto, constatada mediante teste com solução de $\mathrm{AgNO}_{3}$. Após a eliminação do referido íon, cada tubo foi centrifugado e seu sobrenadante descartado. Ao final, o material presente em cada tubo foi ressuspendido com água destilada e transferido para frasco de vidro.

As suspensões obtidas foram utilizadas para o preparo de lâminas orientadas, que, após secagem em temperatura ambiente, foram irradiadas com raios $X$ em um difratômetro computadorizado Philips PW $1830^{\circledR}$.

O equipamento, provido de ânodo de cobre e filtro de níquel, foi operado com corrente de $40 \mathrm{~mA}$ e diferença de potencial de $40 \mathrm{kV}$ no tubo de raios $\mathrm{X}$. A velocidade angular do goniômetro foi igual a $0,02{ }^{\circ} 2 \theta \mathrm{s}^{-1} \mathrm{e}$ os reflexos foram detectados entre $5 \mathrm{e}$ $45^{\circ} 2 \theta$.

Após a obtenção dos difratogramas dos materiais saturados com $\mathrm{K}$ e com $\mathrm{Mg}$ e secos àtemperatura ambiente, tratamentos auxiliares (glicolação e aquecimentos à 
350 e $550^{\circ} \mathrm{C}$ ) foram realizados em algumas lâminas visando-se à identificação mais precisa de argilominerais do tipo 2:1 nas amostras em que os mesmos se mostraram presentes.

\subsection{Fração argila concentrada em óxidos de ferro}

Inicialmente, realizou-se a concentração dos óxidos de ferro na fração argila dos solos, seguindo-se os procedimentos propostos por Norrish \& Taylor (1961) e modificados por Kämpf \& Schwertmann (1982).

As frações argila concentradas em óxidos de ferro foram analisadas por DRX , em lâminas não orientadas, com o emprego de um difratômetro computadorizado Siemens $\mathrm{D} 5000^{\circledast}$, equipado com ânodo de cobalto e filtro de ferro. O equipamento foi operado com corrente de $25 \mathrm{~mA}$, diferença de potencial de $35 \mathrm{kV}$ e com velocidade do goniômetro igual a $0,01^{\circ} 2 \theta \mathrm{s}^{-1}$. Os reflexos foram detectados entre 20 e $45^{\circ} 2 \theta$.

Com o objetivo de se corrigir os desvios causados pelo difratômetro nas posições dos picos de interesse dos óxidos de ferro, preparou-se uma lâmina de quartzo finamente moído, a qual foi irradiada nas mesmas condições descritas para as amostras (Fontes \& Weed, 1991).

Os difratogramas obtidos foram analisados com o programa computacional EVA 3.09, objetivando-se a identificação dos minerais presentes e a determinação analítica das áreas sob os picos de interesse.

\subsubsection{Cálculos mineralógicos}

\subsection{Estimativa da substituição por alumínio nos óxidos de ferro}

\subsection{Hematita}

A estimativa da substituição de Fe por Al na estrutura da hematita foi realizada empregando-se a equação desenvolvida por Schwertmann et al. (1979), a partir do estudo da referida substituição em hematitas sintetizadas a $70^{\circ} \mathrm{C}$. Essa equação é dada por: 


$$
A l=30,768-61,07 \cdot a_{0}
$$

em que:

Al - substituição em Al na estrutura da hematita $\left(\mathrm{mol} \mathrm{mol}^{-1}\right)$;

$\mathrm{a}_{\mathrm{o}}$ - dimensão a da célula unitária da hematita, expressa em nm e calculada a partir do valor obtido por DRX do espaçamento interplanar referente ao plano 110 da hematita, expresso em nm:

$$
a_{0}=2 . d_{110}
$$

\subsection{Goethita}

O grau de substituição de Fe por Al na estrutura da goethita foi estimado empregando-se as equações desenvolvidas por Schulze (1984), as quais são dadas por:

$$
\begin{aligned}
& A \mathrm{I}=17,30-57,2 \cdot \mathrm{C}_{\mathrm{o}} \\
& \mathrm{C}_{\mathrm{o}}=\left[\left(\frac{1}{10 \cdot \mathrm{d}_{111}}\right)^{2}-\left(\frac{1}{10 \cdot \mathrm{d}_{110}}\right)^{2}\right]^{-\frac{1}{2}}
\end{aligned}
$$

em que :

Al - substituição por Al na estrutura da goethita $\left(\mathrm{mol} \mathrm{mol}^{-1}\right)$; $\mathrm{C}_{\mathrm{o}}$ - dimensão $\mathrm{c}$ da célula unitária da goethita, nm;

$d_{111}$ e $d_{110}$ - valores obtidos por DRX dos espaçamentos interplanares referentes aos planos 111 e 110 da goethita, nm.

\subsection{Relação hematita/(hematita+goethita)}

O cálculo da relação entre o teor de hematita e da soma dos teores de hematita e goethita na fração argila $(R)$ foi realizado com base na observação de Jones 
(1981) de que, uma mistura de hematita e goethita puras, na proporção 1:1, apresenta $A_{G+110} / A_{H m 104}$ igual a 0,708. A equação empregada foi a seguinte:

$$
R=\frac{H m}{H m+G t}=\frac{1}{\frac{A_{G+110}}{A_{H m 104} \cdot 0,708}+1}
$$

em que:

$\mathrm{Hm}$ - teor de hematita na fração argila, $\mathrm{g} \mathrm{kg}^{-1}$;

Gt - teor de goethita na fração argila, $\mathrm{g} \mathrm{kg}^{-1}$;

$A_{G+110}$ - área sob o pico de difração de raios $X$ referente ao plano 110 da goethita;

$\mathrm{A}_{\mathrm{Hm} 104}$ - área sob o pico de difração de raios $\mathrm{X}$ referente ao plano 104 da hematita.

\subsection{Teores de hematita e goethita}

A estimativa dos teores de hematita e goethita presentes na fração argila dos solos foi realizada utilizando-se o método da alocação (Resende et al., 1987; Netto, 1996) com pequena modificação, partindo-se da premissa de que os referidos minerais eram os óxidos de ferro presentes em quantidades mais expressivas na fração argila dos solos estudados.

O método empregado no presente trabalho fundamenta-se na divisão do teor de $\mathrm{Fe}$ presente nos óxidos de ferro cristalinos da fração argila $\left(\mathrm{Fe}_{\mathrm{DC}}-\mathrm{Fe}_{\mathrm{OXA}}\right)$ em teores do elemento associados aos minerais hematita e goethita. Essa divisão foi efetuada com base nos valores da relação $\mathrm{R}$ e do grau de substituição de Fe por Al obtidos por DRX.

\subsection{Teores de óxidos mal cristalizados}

Os teores de ferrihidrita $\left(\mathrm{Fe}_{5} \mathrm{HO}_{8} .4 \mathrm{H}_{2} \mathrm{O}\right)$ foram estimados a partir dos teores de $\mathrm{Fe}_{\text {OXA }}$ da fração argila multiplicando-os por 1,7 (Parfitt \& Childs, 1988; Fontes \& Weed, 
1996). Similarmente, a estimativa dos teores de óxido de alumínio de baixa cristalinidade foi feita expressando-os sob a forma de $\mathrm{Al}(\mathrm{OH})_{3}$ a partir da multiplicação dos teores de $\mathrm{Al}_{\text {OXA }}$ da fração argila por 2,89 (Fontes \& Weed, 1996).

\subsection{Semiquantificação dos teores de minerais cristalinos e óxidos mal cristalizados na fração argila total}

Considerando-se que os teores de caulinita e gibbsita foram estimados na fração argila desferrificada, correções foram realizadas de modo que os teores de todos os minerais considerados fossem expressos em relação àfração argila total.

\subsubsection{Adsorção de sulfato}

\subsubsection{Isotermas de adsorção}

Subamostras em triplicatas de 2,5 $\mathrm{g}$ de TFSA foram submetidas ao equilíbrio, em temperatura ambiente, com $25 \mathrm{~mL}$ de solução de $\mathrm{CaCl}_{2}$ 0,01 $\mathrm{mol} \mathrm{L}^{-1}$, contendo 11 diferentes concentrações de sulfato, obtidas a partir da dissolução do sal $\mathrm{K}_{2} \mathrm{SO}_{4}$. As suspensões foram agitadas em agitador horizontal (240 oscilações por minuto) por 24 horas. A definição das concentrações de sulfato adicionadas foi baseada no valor do fósforo remanescente (Alvarez $\mathrm{V}$ et al., 2000).

Terminada a agitação, as suspensões foram filtradas, utilizando-se papel de filtro Whatman $42^{\circledR}$, e as concentrações remanescentes de sulfato nas soluções determinadas turbidimetricamente empregando-se o método proposto por Chesnin \& Yien (1950). A partir da diferença entre as quantidades iniciais de sulfato nas soluções aplicadas e suas quantidades remanescentes na solução de equilíbrio, foram calculadas as quantidades adsorvidas (q) do referido ânion.

Os resultados experimentais de adsorção foram utilizados para ajustamento das equações de Langmuir e Freundlich, amplamente utilizadas em estudos dessa natureza.

A equação de Langmuir é dada por: 


$$
q=\frac{k c b}{1+k c}
$$

em que:

$\mathrm{q}=$ quantidade adsorvida do íon, $\mu \mathrm{g} \mathrm{g}^{-1}$;

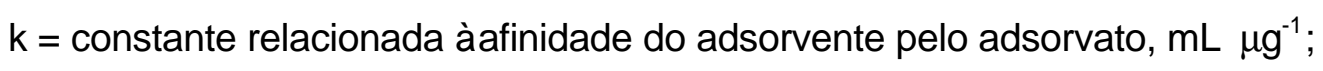

$\mathrm{c}=$ concentração do íon na solução de equilíbrio, $\mu \mathrm{g} \mathrm{mL}^{-1}$;

$\mathrm{b}=$ quantidade máxima do íon passível de ser adsorvida pela fase sólida, $\mu \mathrm{g} \mathrm{g}^{-1}$;

A equação de Freundlich é dada por:

$$
q=k c^{1 / n}
$$

em que:

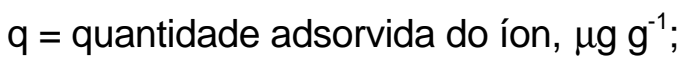

$\mathrm{k}=$ constante, $\mu \mathrm{g}^{(1-1 / \mathrm{n})} \mathrm{g}^{-1} \mathrm{~mL}^{1 / \mathrm{n}}$;

$\mathrm{c}=$ concentração do íon na solução de equilíbrio, $\mu \mathrm{g} \mathrm{mL}^{-1}$;

$\mathrm{n}=$ constante, adimensional.

As estimativas dos parâmetros das equações (8) e (9) foram realizadas por meio de análise de regressão não-linear (PROC NLIN, SAS Institute,1994 - método DUD).

A partir dos valores estimados para os parâmetros $k$ e $n$ da equação de Freundlich, foi calculada a variável ku proposta por Chen et al. (1999) visando-se à obtenção de um índice de adsorção de sulfato que, ao contrário da constante k, apresentasse unidade independente do valor do parâmetro $n$. A variável $k_{u}$ foi calculada utilizando-se a seguinte equação:

$$
k_{u}=\frac{k}{c^{(n-1 / n)}}
$$


em que:

$\mathrm{k}_{\mathrm{u}}=$ variável uniformizadora, $\mathrm{mL} \mathrm{g}^{-1}$;

$\mathrm{k}=$ constante, $\mu \mathrm{g}^{(1-1 / \mathrm{n})} \mathrm{g}^{-1} \mathrm{~mL}^{1 / \mathrm{n}}$;

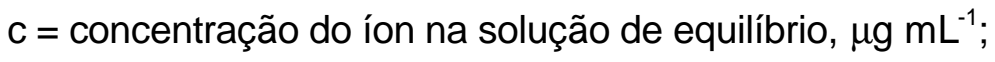

$\mathrm{n}=$ constante, adimensional.

Para fins comparativos, os valores de $k_{u}$ foram calculados para a maior concentração de sulfato na solução de equilíbrio que foi comum a todas as amostras estudadas.

\subsubsection{Enxofre remanescente}

Adicionalmente ao método das isotermas, a capacidade adsortiva de sulfato das amostras estudadas foi avaliada por meio da determinação do enxofre remanescente (S-rem) (Alvarez V. et al., 1983), efetuada em triplicatas na TFSA e na fração argila. As determinações de S-rem consistiram na agitação, por uma hora, de subamostras de TFSA com solução de $\mathrm{CaCl}_{2} 0,01 \mathrm{~mol} \mathrm{~L}^{-1}$ contendo $20 \mu \mathrm{g} \mathrm{S} \mathrm{mL}^{-1}$ na proporção 1:10 (sólido-solução), na filtragem das suspensões e na quantificação turbidimétrica do enxofre que permaneceu em solução. No caso da fração argila, utilizou-se o mesmo procedimento adotado para a TFSA, contudo a solução de $\mathrm{CaCl}_{2}$ $0,01 \mathrm{~mol} \mathrm{~L}^{-1}$ utilizada apresentou $10 \mu \mathrm{g} \mathrm{S} \mathrm{mL}{ }^{-1}$ e a relação sólido-solução empregada foi de 1:50. Todos os valores de enxofre remanescente foram expressos sob a forma de $\mathrm{SO}_{4}{ }^{2-}$ multiplicando-se as concentrações de enxofre por 3.

\subsubsection{Dessorção de sulfato}

A avaliação da dessorção de sulfato pelas amostras em estudo foi realizada em três etapas.

Na primeira, determinou-se a liberação do sulfato extraível com a solução de $\mathrm{CaCl}_{2}$ 0,01 mol L-1, que corresponde ao sulfato solúvel e à parte do adsorvido (Tabatabai, 1982). Para tanto, subamostras de $2,5 \mathrm{~g}$ de TFSA foram transferidas em triplicatas para tubos de centrífuga de $50 \mathrm{~mL}$ aos quais foram também adicionados 25 
$\mathrm{mL}$ de solução de $\mathrm{CaCl}_{2} \quad 0,01 \mathrm{~mol} \mathrm{~L}^{-1}$. Os tubos foram agitados por 24 horas em agitador vertical e centrifugados; em seguida, os sobrenadantes foram filtrados e analisados para a quantificação turbidimétrica do íon sulfato empregando-se o método de Chesnin \& Yien (1950).

$\mathrm{Na}$ segunda etapa, subamostras de 2,5g de TFSA foram transferidas para tubos de centrífuga de $50 \mathrm{~mL}$, com massas previamente conhecidas, aos quais foram adicionados $25 \mathrm{~mL}$ de solução de $\mathrm{CaCl}_{2} 0,01 \mathrm{~mol} \mathrm{~L}^{-1}$ contendo $60 \mu \mathrm{g} \mathrm{SO}_{4}{ }^{2-} \mathrm{mL}^{-1}$. Após agitação por 24 horas seguida de centrifugação, os sobrenadantes foram filtrados, os tubos pesados de modo a se conhecer os volumes de solução que permaneceram junto à fase sólida e as soluções resultantes analisadas quanto à concent ração de sulfato. Os teores de sulfato adsorvidos pelas amostras foram calculados descontando-se das quantidades aplicadas as quantidades que permaneceram em solução e as quantidades de sulfato determinadas na etapa anterior.

Para a dessorção do sulfato adsorvido, terceira etapa dessa avaliação, adicionou-se em cada tubo um volume de solução de $\mathrm{CaCl}_{2} 0,01 \mathrm{~mol} \mathrm{~L}^{-1}$ que, somado ao volume da solução remanescente, permitisse ao volume final ser igual a $25 \mathrm{~mL}$. Após 24 horas de agitação, os tubos foram centrifugados e os sobrenadantes filtrados visando-se àposterior determinação das concentrações de sulfato nos mesmos. Todas as operações foram realizadas em triplicata e as quantidades dessorvidas foram expressas sob a forma de percentual do adsorvido.

\subsubsection{Análises estatísticas}

As análises estatísticas dos resultados experimentais consistiram na aplicação do teste $\mathrm{F}$ à análise de variância dos dados, na execução do teste de comparações múltiplas de Tukey e na aplicação do teste t para comparação de médias de amostras independentes e para a avaliação da significância de coeficientes de correlação linear simples. Todas as análises supracitadas foram realizadas utilizando-se o software Statistical Analysis System - SAS ${ }^{\circledR}$ - versão 6.11. 


\section{RESULTADOS E DISCUSSÃO}

\subsection{Caracterização física}

A argila é a fração granulométrica dominante na maior parte das amostras estudadas (Tabela 2). Do conjunto de amostras avaliadas, 67\% apresentam mais que $350 \mathrm{~g} \mathrm{~kg}^{-1}$ de argila, limite inferior da classe textural argilosa. Os baixos valores da relação silte/argila indicam que em geral os teores de silte nas amostras são baixos. Para os solos argilosos e muitos argilosos, a relação silte/argila média foi menor que 0,6, limite abaixo do qual o teor de silte, na maior expressão do horizonte $B$ de solos pertencentes às essas classes texturais, é considerado baixo. Apenas em dois Latossolos Vermelhos argilosos (amostras 1 e 2) e para um Argissolo Vermelho (amostra 12) foram observados valores maiores que 0,6 para a referida relação. Para os solos de textura média, o valor médio da relação silte/argila foi igual a 0,33 , indicando também baixo teor de silte. Nenhuma amostra pertencente a essa classe textural apresentou relação silte/argila maior que 0,70 , valor abaixo do qual os teores de silte são considerados baixos para os solos de textura média (Embrapa, 1999).

Os teores de silte dos Latossolos correlacionaram-se com os teores de Fe extraído no ataque sulfúrico $\left(r=0,94^{* *}\right)$ e nas dissoluções efetuadas com ditionitocitrato $\left(r=0,92^{\star *}\right)$ e com oxalato ácido de amônio na TFSA $\left(0,92^{\star \star}\right)$. As relações diretas observadas entre os teores de silte e as formas de ferro mencionadas reforçam a idéia de que a fração silte de Latossolos mais intemperizados é formada por microagregados de minerais da fração argila, que possuem estabilidade para resistir æ̀s dispersões química e mecânica durante os procedimentos de análise textural. Esses microagregados apresentariam óxidos de ferro cristalinos em sua constituição, ao passo que as formas mal cristalizadas dos referidos óxidos atuariam como agentes cimentantes nas partículas de silte (Dick \& Schwertmann, 1996). 
Tabela 2. Caracterização granulométrica das amostras estudadas.

\begin{tabular}{|c|c|c|c|c|c|c|}
\hline \multirow{2}{*}{ Núm. } & \multirow{2}{*}{ Classe } & Areia & Silte & Argila & \multirow{2}{*}{ Relação silte/argila } & \multirow{2}{*}{ Classe textural } \\
\hline & & 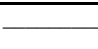 & $\mathrm{g} \mathrm{kg}^{-1}$ & $\bar{z}$ & & \\
\hline 1 & LVwf & 133 & 338 & 529 & 0,64 & Argilosa \\
\hline 2 & LVef & 214 & 305 & 481 & 0,63 & Argilosa \\
\hline 3 & LVdf & 292 & 165 & 543 & 0,30 & Argilosa \\
\hline 4 & LVwf & 44 & 309 & 647 & 0,48 & Muito argilosa \\
\hline 5 & LAw & 519 & 157 & 324 & 0,48 & Média \\
\hline 6 & LVd & 103 & 123 & 774 & 0,16 & Muito argilosa \\
\hline 7 & LVAd & 667 & 89 & 244 & 0,36 & Média \\
\hline 8 & LVAd & 522 & 57 & 421 & 0,14 & Argilosa \\
\hline 9 & NVef & 175 & 228 & 597 & 0,38 & Argilosa \\
\hline 10 & PVAd & 574 & 79 & 347 & 0,23 & Média \\
\hline 11 & PVAd & 747 & 48 & 205 & 0,23 & Média \\
\hline 12 & PVe & 217 & 308 & 475 & 0,65 & Argilosa \\
\hline 13 & $P V d$ & 210 & 158 & 632 & 0,25 & Argilosa \\
\hline 14 & PVAe & 129 & 292 & 579 & 0,50 & Argilosa \\
\hline 15 & RQo & 914 & 75 & 11 & 6,82 & Muito arenosa \\
\hline
\end{tabular}

\subsection{Caracterizações química e eletroquímica de rotina}

As amostras estudadas são, em sua maioria, ácidas e de baixa fertilidade (Tabela 3). Com relação à acidez, $73 \%$ são ácidas ou muito ácidas $\left(\mathrm{pH} \mathrm{CaCl}_{2}\right.$ menor ou igual a 5,0). No que se refere àsaturação por bases, onze amostras apresentam-se como distróficas e quatro como eutróficas. Os teores de fósforo são baixos ou muito baixos em todas as amostras avaliadas ( $P$ resina $<6 \mathrm{mg} \mathrm{dm}^{-3}$ ), ao passo que os teores de enxofre disponível são classificados como altos $\left(S>10 \mathrm{mg} \mathrm{dm}^{-3}\right)$ em $60 \%$ delas (Raij et al., 1996). Dentre essas amostras, as referentes a três Latossolos (amostras 2, 6 e 8), ao Nitossolo e a um Argissolo (amostra 13) foram as únicas coletadas em áreas cultivadas; desse modo, é provável que os teores de sulfato encontrados nas mesmas, os quais estão entre os mais elevados no conjunto de solos 
avaliados, sejam decorrentes da lixiviação desse íon após adubações e correções efetuadas na camada arável.

Tabela 3. Caracterização eletroquímica e química das amostras estudadas.

\begin{tabular}{|c|c|c|c|c|c|c|c|c|c|c|c|c|c|c|}
\hline \multirow[t]{2}{*}{ Núm. } & \multirow[t]{2}{*}{ Classe } & \multirow{2}{*}{$\begin{array}{c}\mathrm{pH} \\
\mathrm{CaCl}_{2}\end{array}$} & \multirow{2}{*}{$\frac{\text { M.O. }}{\mathrm{g} \mathrm{dm}^{-3}}$} & $P$ & S & $\mathrm{K}^{+}$ & $\mathrm{Ca}^{2+}$ & $\mathrm{Mg}^{2+}$ & $\mathrm{Al}^{3+}$ & $\mathrm{H}+\mathrm{Al}$ & S.B. & $\mathrm{T}$ & \multirow{2}{*}{\multicolumn{2}{|c|}{$\begin{array}{c}m \quad V \\
-\%-\end{array}$}} \\
\hline & & & & \multicolumn{2}{|c|}{$\mathrm{mg} \mathrm{dm}^{-3}$} & \multicolumn{7}{|c|}{$\longrightarrow \mathrm{mmol}_{\mathrm{c}} \mathrm{dm}^{-3} \longrightarrow$} & & \\
\hline 1 & LVwf & 5,0 & 10,4 & 5 & 5 & 0,5 & 4 & 1 & 0,0 & 31 & 5,5 & 36,5 & 0,0 & 15 \\
\hline 2 & LVef & 5,5 & 13,4 & 5 & 37 & 0,2 & 43 & 4 & 0,0 & 20 & 47,2 & 67,2 & 0,0 & 70 \\
\hline 3 & LVdf & 4,3 & 7,8 & 3 & 2 & 0,3 & 3 & 1 & 0,7 & 38 & 4,3 & 42,3 & 14,6 & 10 \\
\hline 4 & LVwf & 5,4 & 8,4 & 3 & 1 & 1,1 & 4 & 1 & 0,0 & 25 & 6,1 & 31,1 & 0,0 & 20 \\
\hline 5 & LAw & 5,6 & 3,5 & 3 & 17 & 2,1 & 4 & 1 & 0,0 & 18 & 7,1 & 25,1 & 0,0 & 28 \\
\hline 6 & LVd & 4,9 & 12,8 & 2 & 109 & 0,5 & 15 & 8 & 0,1 & 28 & 23,5 & 51,5 & 0,3 & 46 \\
\hline 7 & LVAd & 4,8 & 3,6 & 2 & 35 & 1,5 & 8 & 2 & 0,0 & 16 & 11,5 & 27,5 & 0,0 & 42 \\
\hline 8 & LVAd & 4,8 & 4,1 & 3 & 78 & 0,1 & 7 & 3 & 0,0 & 22 & 10,1 & 32,1 & 0,0 & 31 \\
\hline 9 & NVef & 5,0 & 3,1 & 4 & 102 & 0,3 & 40 & 3 & 0,0 & 22 & 43,3 & 65,3 & 0,0 & 66 \\
\hline 10 & PVAd & 4,0 & 2,6 & 2 & 15 & 1,2 & 10 & 13 & 8,2 & 47 & 24,2 & 71,2 & 25,3 & 34 \\
\hline 11 & PVAd & 3,7 & 3,6 & 2 & 22 & 0,9 & 4 & 2 & 6,6 & 28 & 6,9 & 34,9 & 48,9 & 20 \\
\hline 12 & $\mathrm{PVe}$ & 5,2 & 5,2 & 3 & 7 & 0,5 & 63 & 17 & 0,0 & 25 & 80,5 & 105,5 & 0,0 & 76 \\
\hline 13 & PVd & 3,8 & 4,1 & 2 & 137 & 0,9 & 7 & 4 & 25,4 & 72 & 11,9 & 83,9 & 68,1 & 14 \\
\hline 14 & PVAe & 4,9 & 20,0 & 4 & 9 & 3,9 & 91 & 23 & 0,0 & 38 & 117,9 & 155,9 & 0,0 & 76 \\
\hline 15 & RQo & 4,0 & 1,0 & 4 & 47 & 0,3 & 6 & 1 & 0,9 & 22 & 7,3 & 29,3 & 10,9 & 25 \\
\hline
\end{tabular}

O cálcio, cuja adsorção pelo solo pode apresentar relação com a retenção de sulfato (Bolan et al., 1993), foi o cátion predominante no complexo sortivo das amostras estudadas, com exceção das referentes ao Argissolo Vermelho-Amarelo (amostra 11) e Argissolo Vermelho (amostra 13). De acordo com os critérios de Raij et al. (1996), os teores do referido íon não são considerados limitantes para o crescimento radicular em subsuperfície $\left(\mathrm{Ca}^{2+}>4 \mathrm{mmol}_{\mathrm{c}} \mathrm{dm}^{-3}\right)$ em quatro Latossolos (amostras 2, 6, 7 e 8), no Nitossolo, em três Argissolos (amostras 10, 12,e 14) e no 
Neossolo. Assim, como no caso do sulfato, é possível que a presença de teores mais elevados de $\mathrm{Ca}^{2+}$ nos Latossolo Vermelho Eutroférrico, no Latossolo Vermelho Distrófico, no Nitossolo Vermelho Eutroférrico, no Argissolo Vermelho Eutrófico e no Argissolo Vermelho-Amarelo Eutrófico, esse último também localizado em área agrícola, apresente relação com o manejo químico (adubações e/ou correções) realizado na camada superficial desses solos. Ainda com relação às restrições ao crescimento radicular em camadas subsuperficiais, maiores problemas seriam observados no Argissolo Vermelho-Amarelo Distrófico (amostra 11) e no Argissolo Vermelho Distrófico cujos teores de $\mathrm{Al}^{+3}$ são maiores que $5 \mathrm{mmol}_{\mathrm{c}} \mathrm{dm}^{-3}$ e nos quais a saturação por alumínio ultrapassa o valor de $40 \%$. Tais limites, juntamente com teores de $\mathrm{Ca}^{2+}$ inferiores a $4 \mathrm{mmol}_{\mathrm{c}} \mathrm{dm}^{-3}$, foram considerados por Raij et al. (1996) como indicadores de condições químicas desfavoráveis ao crescimento de raízes em camadas subsuperficiais.

\subsection{Formas de ferro e alumínio e ataques sulfúrico e alcalino}

A extração conjunta de Fe e Al vinculados aos óxidos cristalinos e de baixa cristalinidade foi realizada à temperatura ambiente, empregando-se o método do ditionito-citrato $(D C)$ e, portanto, de maneira distinta da normalmente efetuada em estudos dessa natureza, nos quais se emprega o tratamento com ditionito-citratobicarbonato (DCB) em temperatura de $80^{\circ} \mathrm{C}$ (Mehra \& Jackson, 1960). Em relação ao uso de um método alternativo ao do DCB tradicional, Schwertmann \& Carlson (1994) não verificaram diferença estatística entre o procedimento de extração com solução de DCB à temperatura ambiente e à $80^{\circ} \mathrm{C}$ para 75 amostras ricas em goethita provenientes de diferentes partes do mundo e para 30 goethitas de depósitos da Finlândia. Também Barrón \& Torrent (1986), Schwertmann \& Latham (1986), Mesquita Filho \& Torrent (1993) e Dick \& Schwertmann, (1996) são exemplos de outros autores que utilizaram o método de extração em temperatura ambiente com uma única agitação de 16 horas.

Considerando-se os teores normalmente mais elevados e a maior cristalinidade dos óxidos de ferro presentes nos solos das regiões tropicais, acredita-se que uma única extração de 16 horas com a solução de ditionito-citrato não seja capaz de proporcionar uma adequada determinação dos teores de Fe e Al vinculados aos óxidos 
de ferro cristalinos. Nesse sentido, optou-se por realizar cinco extrações sucessivas com a solução de ditionito - citrato, totalizando, portanto, 80 horas de agitação.

Apesar da morosidade em relação ao método original, o procedimento adotado mostrou-se adequado face æ̀s correlações significativas verificadas entre os teores de Fe obtidos no ataque sulfúrico e os teores de $\mathrm{Fe}_{\mathrm{DC}}$ determinados tanto na TFSA $\left(r=0,99^{* *}\right)$ quanto na fração argila $\left(r=0,97^{* *}\right)$. Além da efetividade observada, 0 método utilizado pode proporcionar, em relação ao método tradicional, maior versatilidade para o executor da análise dispensando o uso de capelas e aquecedores e evitando perdas de sólidos aderidos aos bastões de agitação.

Os teores de Fe e Al obtidos na TFSA e na fração argila (Tabela 4) correlacionaram-se significativamente, exibindo coeficientes de $0,97^{* *}, 0,77^{* *}$ e $0,77^{* *}$ para $\mathrm{Fe}_{\mathrm{DC}}, \mathrm{Fe}_{\mathrm{OXA}}$ e $\mathrm{Al}_{\mathrm{OXA}}$, respectivamente. Não foi observada correlação entre os teores de $\mathrm{Al}_{\mathrm{DC}}$ extraídos na TFSA e na fração argila.

Os teores de $\mathrm{Fe}_{\mathrm{DC}}$ determinados na TFSA corresponderam, em termos médios, a 2,0 vezes o obtido para a fração argila. Essa diferença está associada a possível presença de minerais contendo ferro nas frações silte e areia. Os teores de ferro associados aos óxidos mal cristalizados também apresentaram, em média, valores maiores para a TFSA, em comparação com a fração argila.

No caso do $\mathrm{Al}_{\mathrm{DC}}$, observou-se um teor médio na TFSA cerca de 2,2 vezes maior que o obtido na fração argila, algo semelhante ao observado para o $\mathrm{Al}_{\text {OxA }}$. Além da ação do ditionito-citrato sobre a fração grosseira, outras fontes de $\mathrm{Al}_{\mathrm{DC}}$, além dos óxidos de ferro, devem ser consideradas. O alumínio do extrato de ditionito-citrato inclui o elemento que está na estrutura dos óxidos de ferro, as formas de alumínio pouco cristalinas e complexadas pelo citrato e, possivelmente, o alumínio presente entre as camadas de minerais contendo hidróxi nas entrecamadas (Fontes, 1995).

Os teores de $\mathrm{Fe}_{\mathrm{DC}}$ extraídos tanto na TFSA quanto na fração argila correlacionaram-se significativamente com os teores de hematita, exibindo coeficientes iguais a $0,93^{\star *}$ em ambos os casos. Em relação à goethita, não foram observadas correlações significativas entre os seus teores na fração argila e os teores de $\mathrm{Fe}_{\mathrm{DC}}$. Tal fato provavelmente se deve à diminuição da taxa de dissolução da goethita causada pelo incremento na substituição por alumínio em sua rede cristalina (Torrent et al., 1987; Schwertmann, 1991). 
Tabela 4. Teores de ferro (Fe) , alumínio (Al) e silício (Si) obtidos após ataque sulfúrico e alcalino na TFSA ${ }^{(1)}$, índices Ki e Kr, teores de ferro e alumínio obtidos após dissoluções seletivas com ditionito-citrato de sódio ( $\mathrm{Fe}_{\mathrm{DC}}$ e $\left.\mathrm{Al}_{\mathrm{DC}}\right)$ e oxalato ácido de amônio ( $\mathrm{Fe}_{\mathrm{OXA}}$ e AloXA $)$ na TFSA e na fração argila ${ }^{(1)}$ e relações $F e_{O X A} \backslash F e_{D C}$.

\begin{tabular}{|c|c|c|c|c|c|c|c|c|c|c|c|c|c|c|c|c|}
\hline \multirow{3}{*}{ Núm. } & \multirow{3}{*}{ Classe } & \multirow{2}{*}{$\mathrm{Fe}$} & \multirow{2}{*}{ Al } & \multirow{2}{*}{$\mathrm{Si}$} & \multirow{3}{*}{$\mathrm{Ki}$} & \multirow{3}{*}{$\mathrm{Kr}$} & $\mathrm{Fe}_{\mathrm{DC}}$ & $A l_{D C}$ & $\mathrm{Fe}_{\mathrm{OXA}}$ & Aloxa & $\mathrm{Fe}_{\mathrm{OXA}} / \mathrm{Fe}_{\mathrm{DC}}$ & $\mathrm{Fe}_{\mathrm{DC}}$ & $\mathrm{Al}_{\mathrm{DC}}$ & Fe $e_{X A}$ & Aloxa & $\mathrm{Fe}_{\mathrm{OXA}} / \mathrm{Fe}_{\mathrm{DC}}$ \\
\hline & & & & & & & \multicolumn{5}{|c|}{ TFSA } & \multicolumn{5}{|c|}{$\operatorname{Argila}^{(*)}$} \\
\hline & & \multicolumn{3}{|c|}{$\mathrm{g} \mathrm{kg}^{-1} \longrightarrow$} & & & \multicolumn{5}{|c|}{$\longrightarrow \mathrm{g} \mathrm{kg}^{-1} \longrightarrow$} & \multicolumn{5}{|c|}{$\mathrm{g} \mathrm{kg}^{-1} \longrightarrow$} \\
\hline 1 & LVwf & 309,7 & 284,0 & 119,5 & 0,72 & 0,42 & 196,0 & 13,4 & 18,9 & 12,9 & 0,10 & 130,2 & 10,3 & 8,1 & 6,8 & 0,06 \\
\hline 2 & LVef & 234,6 & 252,3 & 169,2 & 1,14 & 0,71 & 176,5 & 13,2 & 13,9 & 10,0 & 0,08 & 110,8 & 9,0 & 6,0 & 5,1 & 0,05 \\
\hline 3 & LVdf & 209,0 & 222,8 & 127,0 & 0,97 & 0,61 & 161,4 & 8,0 & 12,0 & 7,3 & 0,07 & 116,1 & 7,4 & 6,1 & 5,4 & 0,05 \\
\hline 4 & LVwf & 323,9 & 313,5 & 90,5 & 0,49 & 0,30 & 216,2 & 15,1 & 21,3 & 12,0 & 0,10 & 164,1 & 15,0 & 9,1 & 10,3 & 0,06 \\
\hline 5 & LAw & 121,5 & 181,5 & 90,5 & 0,85 & 0,60 & 70,3 & 16,5 & 2,1 & 5,8 & 0,03 & 49,0 & 13,9 & 1,4 & 3,7 & 0,03 \\
\hline 6 & LVd & 101,0 & 291,1 & 246,1 & 1,44 & 1,18 & 66,9 & 13,9 & 3,5 & 7,1 & 0,05 & 79,6 & 22,8 & 4,2 & 6,2 & 0,05 \\
\hline 7 & LVAd & 38,6 & 87,4 & 84,8 & 1,65 & 1,29 & 24,4 & 3,5 & 1,6 & 1,7 & 0,07 & 22,4 & 4,6 & 1,3 & 1,4 & 0,06 \\
\hline 8 & LVAd & 69,1 & 200,3 & 80,5 & 0,69 & 0,56 & 36,1 & 8,9 & 1,2 & 5,3 & 0,03 & 43,8 & 8,5 & 1,1 & 4,5 & 0,03 \\
\hline 9 & NVef & 201,8 & 228,7 & 209,6 & 1,56 & 1,00 & 151,0 & 12,5 & 15,3 & 3,5 & 0,10 & 118,2 & 11,3 & 10,1 & 4,1 & 0,09 \\
\hline 10 & PVAd & 33,2 & 116,7 & 120,4 & 1,75 & 1,48 & 22,5 & 3,9 & 1,3 & 3,0 & 0,06 & 23,9 & 6,5 & 1,8 & 2,4 & 0,07 \\
\hline 11 & PVAd & 17,9 & 74,5 & 79,0 & 1,81 & 1,56 & 13,2 & 2,5 & 0,7 & 1,7 & 0,05 & 11,9 & 3,5 & 0,9 & 1,1 & 0,08 \\
\hline 12 & Pve & 162,2 & 229,1 & 220,3 & 1,63 & 1,12 & 116,8 & 16,1 & 10,6 & 4,7 & 0,09 & 61,0 & 11,4 & 6,6 & 4,1 & 0,11 \\
\hline 13 & PVd & 85,6 & 233,8 & 227,8 & 1,66 & 1,34 & 61,5 & 12,4 & 4,6 & 4,9 & 0,07 & 64,0 & 17,5 & 5,9 & 5,7 & 0,09 \\
\hline 14 & PVAe & 56,5 & 167,9 & 210,2 & 2,13 & 1,75 & 40,2 & 9,3 & 3,9 & 4,6 & 0,10 & 36,1 & 13,4 & 6,5 & 7,8 & 0,18 \\
\hline 15 & RQo & 7,5 & 24,6 & 24,1 & 1,66 & 1,39 & 6,0 & 1,6 & 0,7 & 1,3 & 0,12 & 0,8 & 0,3 & 0,1 & 0,1 & 0,18 \\
\hline
\end{tabular}

${ }^{(1)}$ Teores expressos sob a forma de óxidos : $\mathrm{SiO}_{2}, \mathrm{Fe}_{2} \mathrm{O}_{3}$ e $\mathrm{Al}_{2} \mathrm{O}_{3} . \quad{ }^{(*)}$ Valor obtido na fração argila e corrigido para a TFSA, considerando o teor de argila da análise granulométrica. 
Análises de correlação linear entre os teores de $\mathrm{Fe}_{\mathrm{DC}}$ na TFSA e na argila e os valores de substituição por alumínio na estrutura da goethita, calculados a partir dos resultados de difratometria de raios $X$, demonstraram que, para as quinze amostras avaliadas, o teor de Fe extraído com ditionito-citrato, tanto na TFSA quanto na argila, apresentou relação inversa com a substituição por alumínio na estrutura da goethita, exibindo, para ambos os casos, um coeficiente de correlação igual a $-0,53^{*}$. Ao considerar-se apenas os Latossolos, verificou-se um incremento no coeficiente de correlação entre a substituição por alumínio na goethita e os teores de $\mathrm{Fe}_{\mathrm{DC}}$ determinados tanto na TFSA quanto na fração argila $\left(r=-0,79^{* *}\right)$.

Apesar da ausência de dados referentes ao diâmetro médio dos cristalitos e à superfície específica das hematitas e goethitas avaliadas no presente trabalho, 0 aumento diferenciado da estabilidade estrutural dos referidos minerais causado pela substituição por Al (Yapp, 1983; Trolard \& Tardy, 1987) parece ser a causa mais provável para a ausência de correlação verificada entre os teores de $\mathrm{Fe}_{\mathrm{DC}} \mathrm{e}$ os teores de goethita. Em que pese a falta de informações mais detalhadas, tal afirmação é, em parte, sustentada pela maior substituição por Al verificada para as goethitas avaliadas no presente trabalho, que em média foi 1,4 vezes superior à observada para as hematita, considerando-se as 14 amostras em que a coexistência desses dois óxidos foi constatada.

Embora a substituição por Al seja normalmente menor na estrutura da hematita (Fontes \& Weed, 1991; Singh \& Gilkes, 1992a; Curi \& Franzmeier, 1994), nem sempre os cristais desse mineral são menores que os da goethita (Kämpf \& Schwertmann, 1985; Singh \& Gilkes, 1992a; Netto, 1996). Conseqüentemente, nem sempre a uma maior superfície específica, como sugerido por Torrent et al. (1987), pode ser atribuída a maior taxa de dissolução apresentada pelas hematitas. Essa afirmação vai ao encontro das observações feitas por Jeanroy et al. (1991), que estudando a dissolução de hematitas e goethitas pedogenéticas, não verificaram efeito da superfície específica das amostras sobre a dissolução redutiva dos referidos óxidos que, por sua vez, apresentou nítida dependência do grau de substituição por Al.

$\mathrm{O}$ teor de Fe obtido por meio de ataque sulfúrico na TFSA $\left(\mathrm{Fe}-\mathrm{H}_{2} \mathrm{SO}_{4}\right)$ do Nitossolo Vermelho Eutroférrico (Tabela 4) foi cerca de $25 \%$ maior que o determinado no Argissolo Vermelho Eutrófico e correspondeu a 2,4 vezes o determinado no 
Argissolo Vermelho Distrófico. A superioridade quanto ao teor de $\mathrm{Fe}_{-} \mathrm{H}_{2} \mathrm{SO}_{4}$ para o Nitossolo estudado no presente trabalho, antigamente classificado como Terra Roxa Estruturada, apresenta concordância com um dos critérios propostos para a distinção entre a classe dos Nitossolos e a dos Argissolos Vermelhos, antigos Podzólicos Vermelho-Escuros, que além de um menor teor de $\mathrm{Fe}-\mathrm{H}_{2} \mathrm{SO}_{4}$, apresentam, em geral, maior gradiente textural que os Nitossolos (Oliveira et al.,1992).

$\mathrm{O}$ uso dos dados referentes aos teores de argila e $\mathrm{Fe}_{2} \mathrm{H}_{2} \mathrm{SO}_{4}$ mostrou-se adequado para a distinção entre Argissolos Vermelhos e Argissolos VermelhoAmarelos, ajustando-se ao critério proposto por Camargo et al. (1982) para a distinção dos antigos Podzólicos Vermelho-Escuro e Podzólicos Vermelho-Amarelos. De acordo com esse critério, o teor de Fe determinado após o ataque sulfúrico na TFSA dos Argissolos Vermelhos deve ser maior que o calculado pela expressão 37,50 + 0,0625A, sendo A o teor de argila expresso em $\mathrm{g} \mathrm{kg}^{-1}$. Por outro lado, para os Argissolos Vermelho-Amarelos o valor de $\mathrm{Fe}_{-} \mathrm{H}_{2} \mathrm{SO}_{4}$ na TFSA deve ser menor que o calculado com a equação supracitada. Com base nessas considerações, pôde-se verificar que os resultados dos cálculos efetuados com os dados do presente trabalho foram concordantes com as relações acima apresentadas e, portanto, compatíveis com a classificação dos Argissolos estudados.

Os valores da relação $\mathrm{Fe}_{\mathrm{OXA}} / \mathrm{Fe}_{\mathrm{DC}}$ determinados tanto na TFSA quanto na fração argila dos solos avaliados foram relativamente baixos, indicando o bom grau de cristalização dos óxidos de ferro, presentes essencialmente sob a forma de hematita e goethita.

Com relação ao estádio de intemperismo dos solos avaliados, observa-se que os mesmos apresentam-se com graus de desenvolvimento bastante distintos, haja vista a variação observada para os valores determinados para o índice $\mathrm{Ki}$, que apresentaram um mínimo de 0,49 e um máximo de 2,13 (Tabela 4).

Considerando-se os valores do índice $\mathrm{Kr}$ e estendendo-se para todas as amostras estudadas o critério estabelecido por Resende \& Santana (1988) para a classificação de Latossolos em cauliníticos e oxídicos, verifica-se que, à priori, os solos representados pelas amostras 1, 2, 3, 4, 5 e 8 seriam classificados como oxídico $(\mathrm{Kr}<0,75)$ ao passo que aqueles nos quais as amostras 6, 7, 9, 10, 11, 12, 13, $14 \mathrm{e}$ 15 foram coletadas seriam cauliníticos $(\mathrm{Kr}>0,75)$. Maiores considerações em relação 
à adequação desse critério para a avaliação indireta da composição mineralógica da fração argila das amostras estudadas serão apresentadas posteriormente.

\subsection{Caracterização mineralógica}

\subsubsection{Difratometria de raios $X$}

Os difratogramas de raios $X$ obtidos para a fração argila desferrificada são apresentados nas Figuras 1 a 3 ao passo que os difratogramas referentes à fração argila concentrada em óxidos de ferro podem ser visualizados nas Figuras 4 a 6 . Embora tratamentos complementares tenham sido efetuados no material desferrificado de alguns solos para a identificação de argilominerais do tipo 2:1, optou-se por apresentar apenas os difratogramas obtidos para as lâminas preparadas com material saturado com magnésio e seco àtemperatura ambiente.

A caulinita $(d=0,238 ; 0,314,0,357$ e $0,710 \mathrm{~nm}$ ) esteve presente em todas as amostras analisadas. A gibbsita ( $d=0,238 ; 0,245 ; 0,437$ e $0,485 \mathrm{~nm}$ ) não foi detectada nas amostras 10,11, 12, 13, 14 e 15. Contudo, como será abordado adiante, verificouse, por meio de análise térmica diferencial, a presença de pequenas quantidades do referido óxido nas frações argila das amostras 10, 13, 14 e 15.

A vermiculita com hidróxi nas entrecamadas (VHE) foi identificada em alguns Latossolos (amostras 2, 5, 6 e 7) concordando com o observado para outros Latossolos brasileiros (Pötter \& Kämpf, 1981; Fontes \& Weed, 1991; Netto, 1996). Além dos Latossolos, em alguns Argissolos (amostras 11, 12, 13 e 14) foi também possível detectar-se a presença da VHE pela observação de seu pico referente ao espaçamento basal de 1,43 nm não alterável pela glicolação, mas que demonstra redução gradual para valores em torno de 1,00 nm após aquecimento (Fontes, 1990).

Embora um pequeno pico referente ao espaçamento de $1,43 \mathrm{~nm}$ possa ser

visualizado na Figura 3e, não foram observadas modificações no mesmo com a realização de tratamentos auxiliares (glicolação e aquecimento). Por essa razão, desconsiderou-se a presença de VHE na fração argila do Neossolo avaliado. 


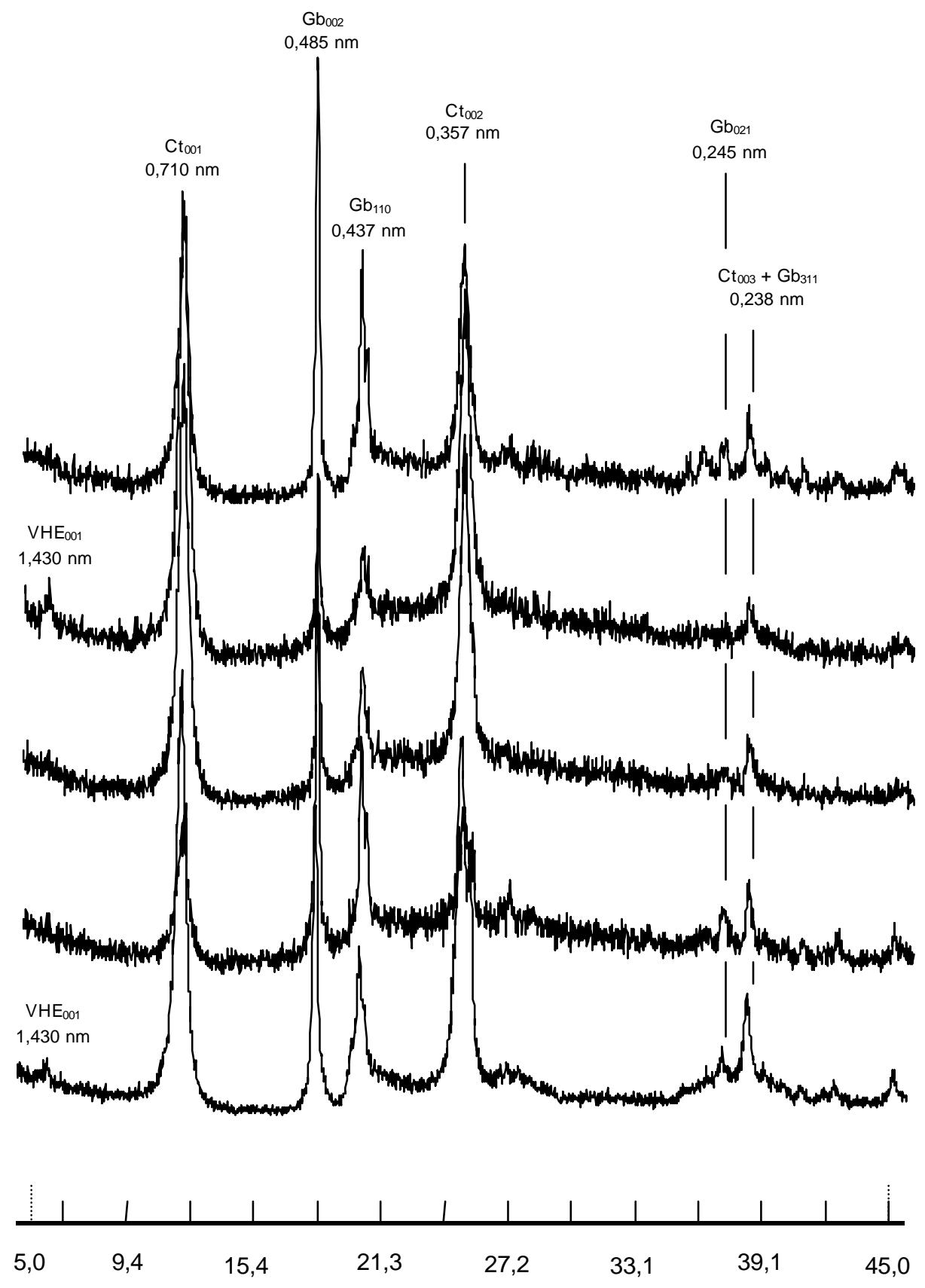

(a)

(b)

(c)

(d)

(e)

${ }^{0} 2 \theta-\operatorname{CuK} \alpha$

Figura 1 - Difratogramas de raios $X$ da fração argila desferrificada do Latossolo Vermelho Acriférrico (amostra 1) (a), Latossolo Vermelho Eutroférrico (amostra 2) (b), Latossolo Vermelho Distroférrico (amostra 3) (c), Latossolo Vermelho Acriférrico (amostra 4) (d) e Latossolo Amarelo Ácrico (amostra 5) (e). VHE = vermiculita com hidróxi nas entrecamadas, $\mathrm{Ct}=$ caulinita, $\mathrm{Gb}=$ gibbsita. 


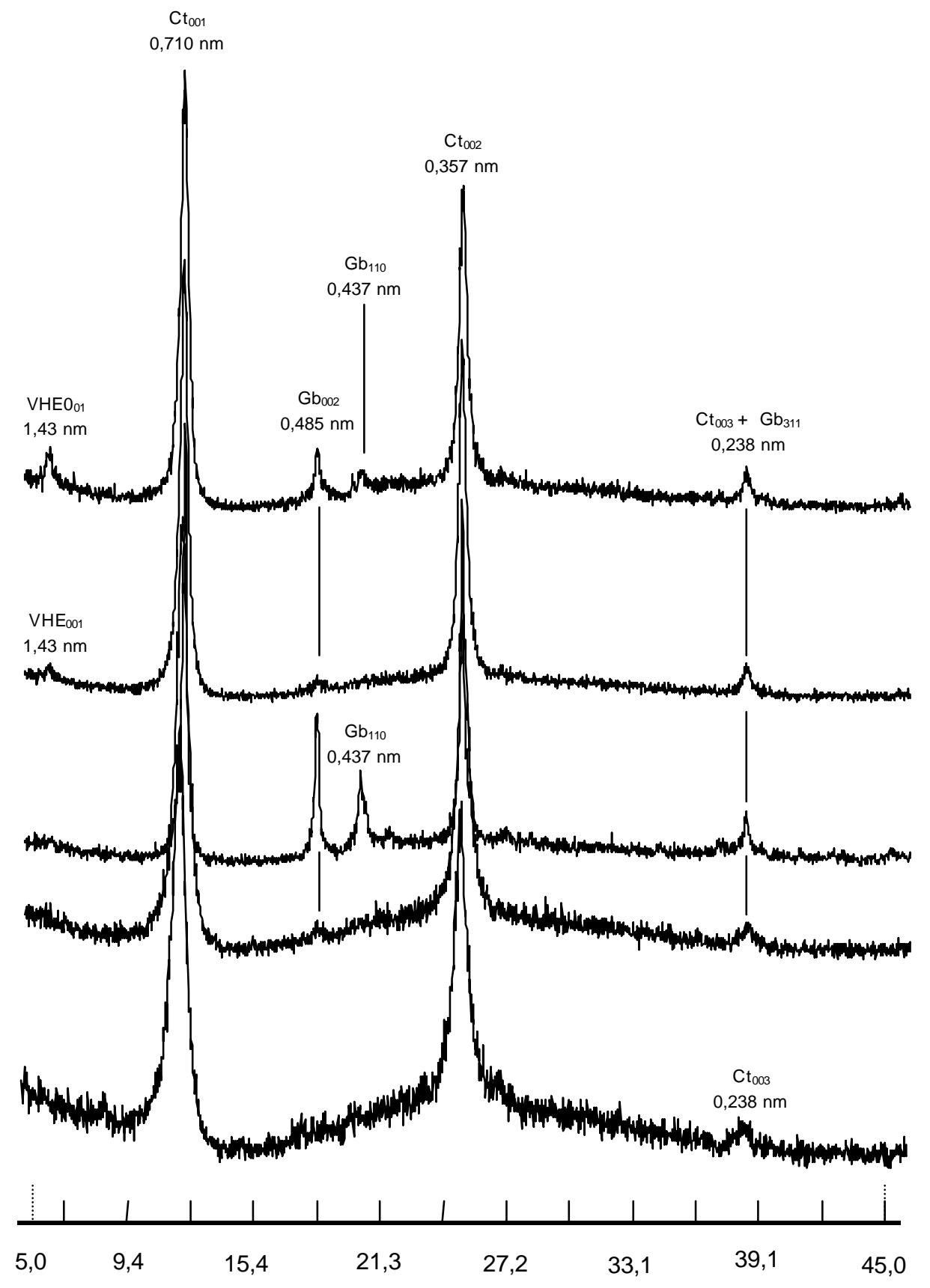

(a)

(b)

(c)

(d)

(e)

${ }^{\circ} 2 \theta-$ CuK $\alpha$

Figura 2 - Difratogramas de raios $X$ da fração argila desferrificada do Latossolo Vermelho Distrófico (amostra 6) (a), Latossolo Vermelho-Amarelo Distrófico (amostra 7) (b), Latossolo Vermelho-Amarelo Distrófico (amostra 8) (c), Nitossolo Vermelho Eutroférrico (amostra 9) (d) e Argissolo Vermelho-Amarelo Distrófico (amostra 10) (e). VHE = vermiculita com hidróxi nas entrecamadas, $\mathrm{Ct}=$ caulinita, $\mathrm{Gb}=$ gibbsita. 


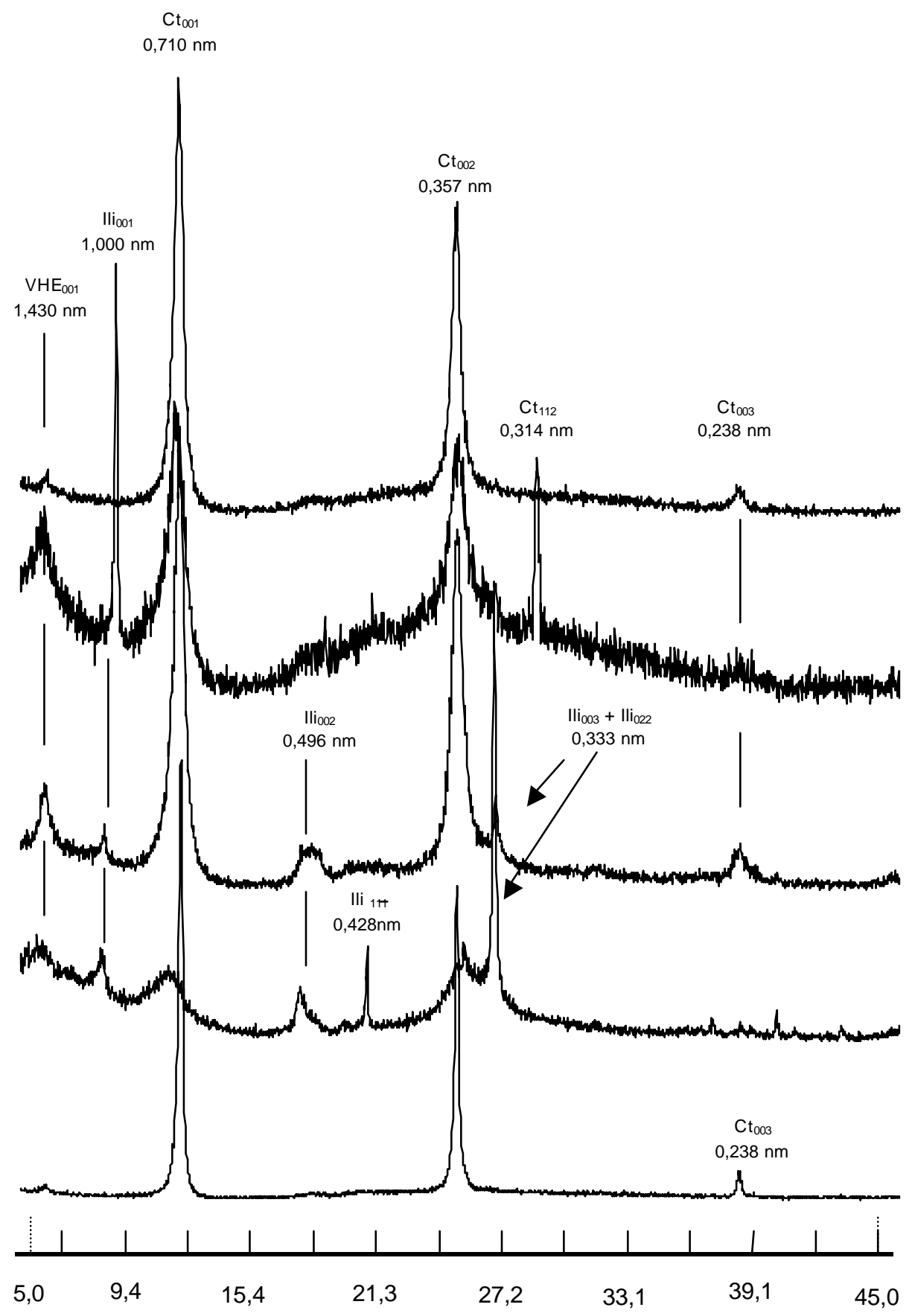

(a)

(b)

(c)

(d)

(e)

${ }^{\circ} 2 \theta-$ CuK $\alpha$

Figura 3 - Difratogramas de raios $X$ da fração argila desferrificada do Argissolo Vermelho-Amarelo Distrófico (amostra 11) (a), Argissolo Vermelho Eutrófico (amostra 12) (b), Argissolo Vermelho Distrófico (amostra 13) (c), Argissolo Vermelho-Amarelo Eutrófico (amostra 14) (d) e Neossolo Quartzarêrico Órtico (amostra 15) (e). VHE = vermiculita com hidróxi nas entrecamadas, $\mathrm{Ct}=$ caulinita, $\mathrm{lli}=$ ilita. 


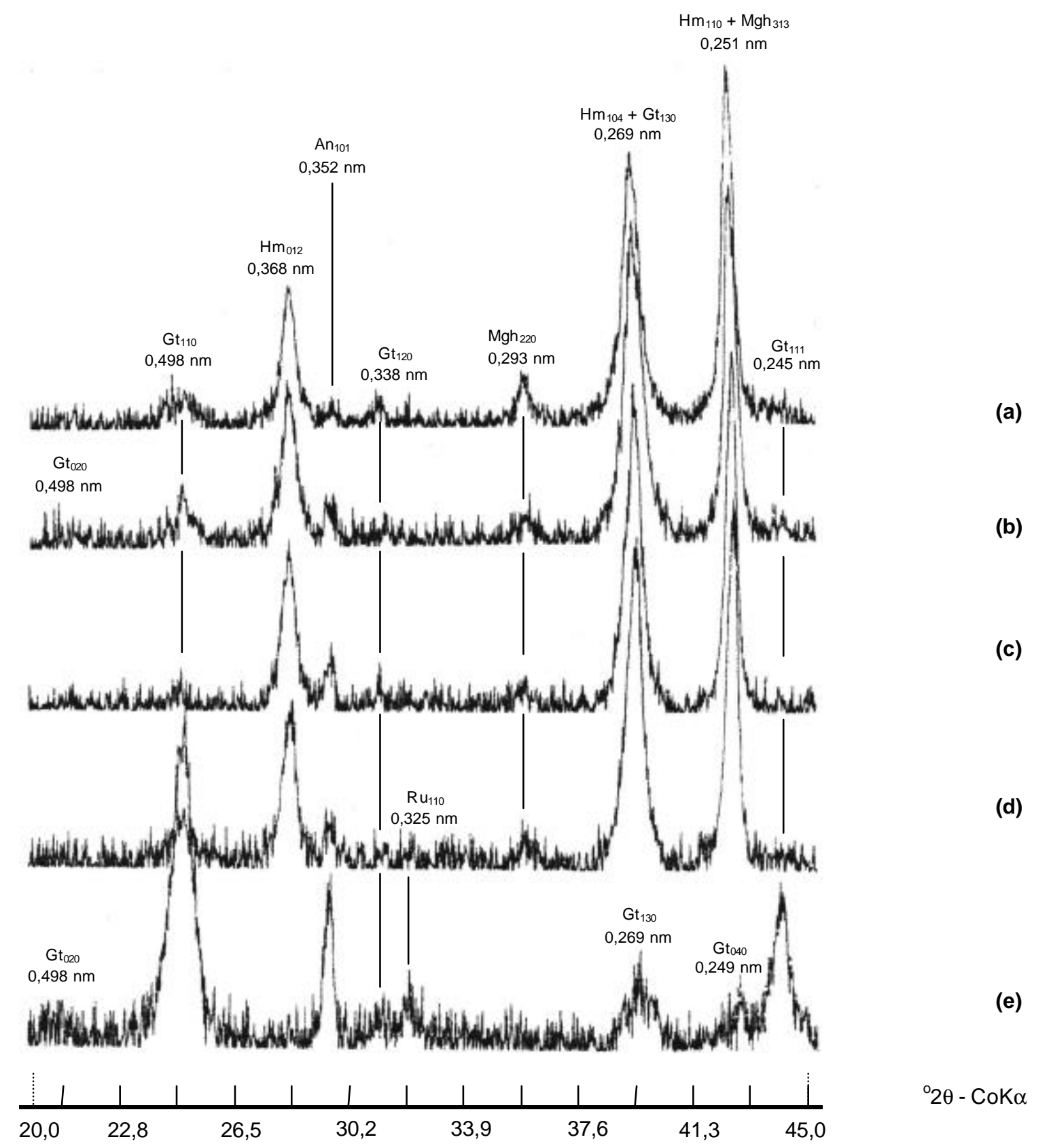

Figura 4 - Difratogramas de raios $X$ da fração argila concentrada em óxidos de ferro do Latossolo Vermelho Acriférrico (amostra 1) (a), Latossolo Vermelho Eutroférrico (amostra 2) (b), Latossolo Vermelho Distroférrico (amostra 3) (c), Latossolo Vermelho Acriférrico (amostra 4) (d) e Latossolo Amarelo Ácrico (amostra 5) (e). Gt = goethita, $\mathrm{Hm}=$ hematita, $\mathrm{An}=$ anatásio, $\mathrm{Rt}=$ rutilo, Mgh =maghemita. 


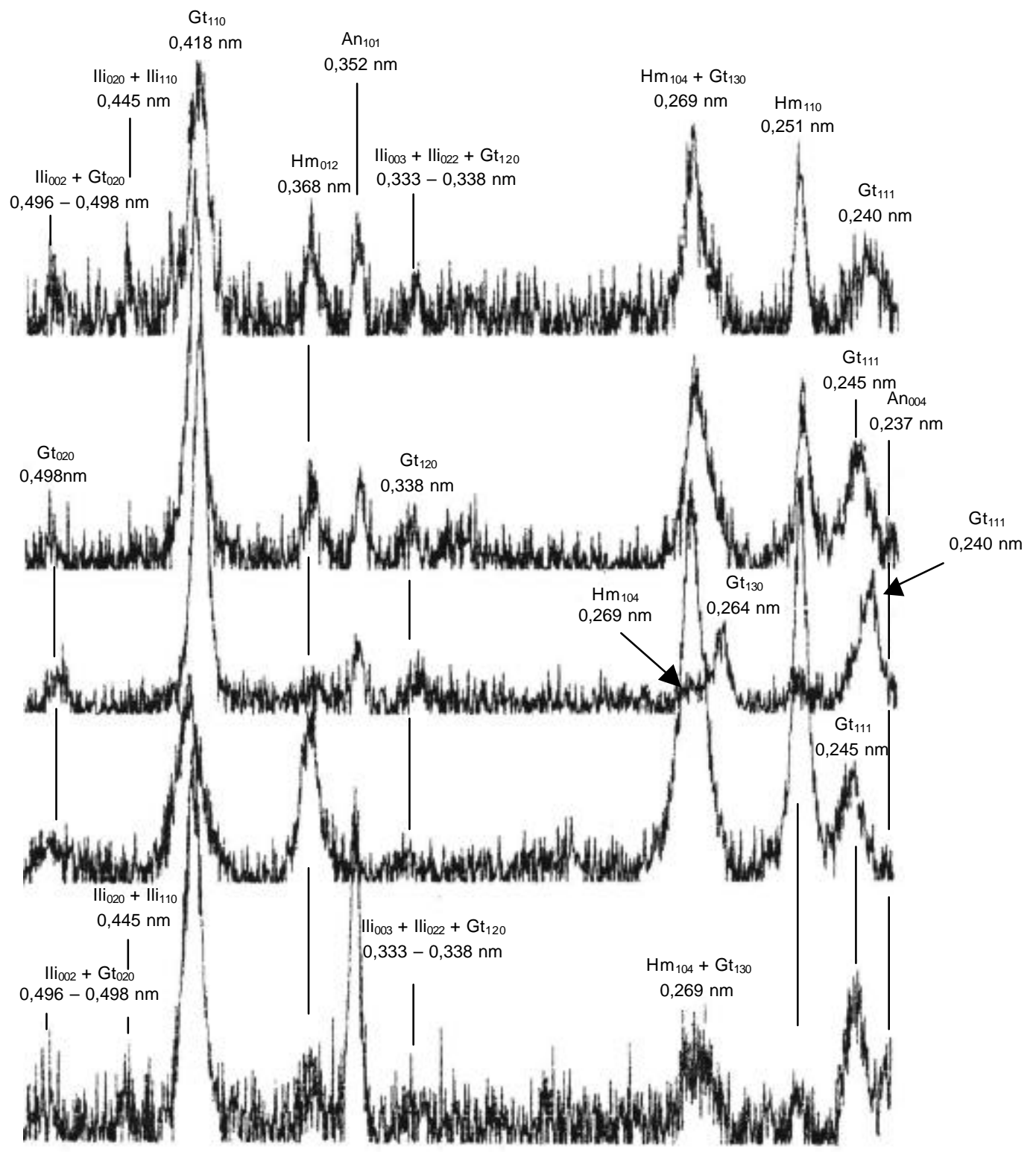

(a)

(b)

(c)

(d)

(e)

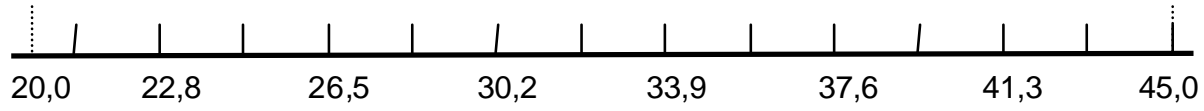

${ }^{\circ} 2 \theta-$ CoK $\alpha$

Figura 5 - Difratogramas de raios $X$ da fração argila concentrada em óxidos de ferro do Latossolo Vermelho Distrófico (amostra 6) (a), Latossolo VermelhoAmarelo Distrófico (amostra 7) (b), Latossolo Vermelho-Amarelo Distrófico (amostra 8) (c), Nitossolo Vermelho Eutroférrico (amostra 9) (d) e Argissolo Vermelho-Amarelo Distrófico (amostra 10) (e). lli = llita, Gt = goethita, $\mathrm{Hm}=$ hematita, $\mathrm{An}=$ anatásio . 


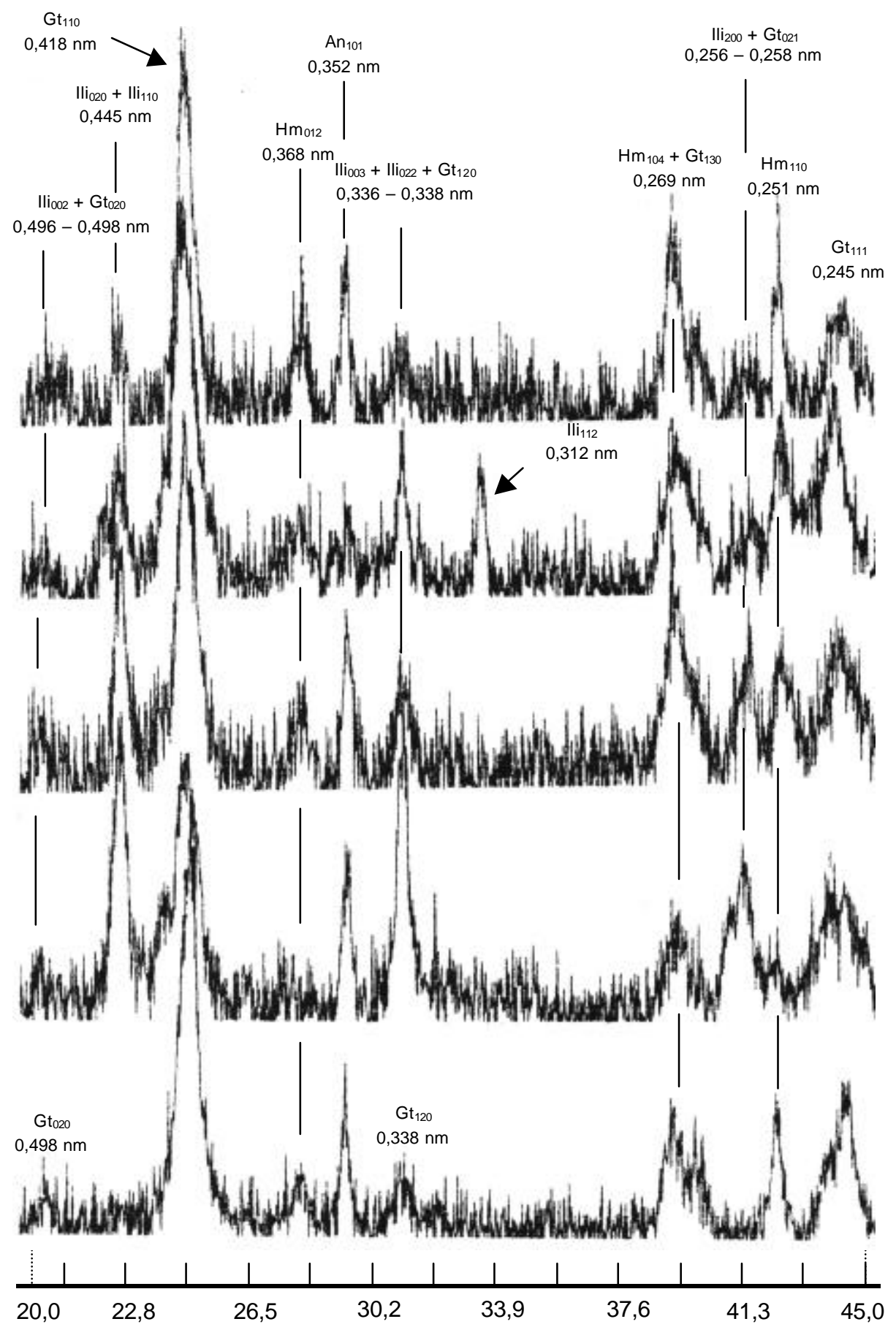

(a)

(b)

(c)

(d)

(e)

Figura 6 - Difratogramas de raios $X$ da fração argila concentrada em óxidos de ferro do Argissolo Vermelho-Amarelo Distrófico (amostra 11) (a), Argissolo Vermelho Eutrófico (amostra 12) (b), Argissolo Vermelho Distrófico (amostra 13) (c), Argissolo Vermelho-Amarelo Eutrófico (amostra 14) (d) e Neossolo Quartzarênico Órtico (amostra 15) (e). lli = ilita, Gt = goethita, $\mathrm{Hm}=$ hematita, $\mathrm{An}=$ anatásio. 
A análise dos difratogramas de raios $X$ das frações argila concentradas em óxidos de ferro demonstra que o rutilo foi identificado pelo seu reflexo correspondente espaçamento basal de $0,325 \mathrm{~nm}$ no Latossolo Vermelho Acriférrico (amostra 4) (Figura 4d) e no Latossolo Amarelo Ácrico (amostra 5) (Figura 5e). O reflexo correspondente ao espaçamento basal de $0,351 \mathrm{~nm}$ do anatásio, mineral de titânio associado ao intemperismo da ilmenita, foi observado nos difratogramas de raios $X$ dos concentrados de óxidos de ferro de todas as amostras.

Em relação aos óxidos de ferro, tanto a hematita quanto a goethita estiveram presentes em todas as amostras estudadas, com exceção da coletada no Latossolo Amarelo Ácrico, na qual a goethita foi o único óxido de ferro cristalino identificado.

$\mathrm{Na}$ Figura $5 \mathrm{c}$, correspondente ao difratograma de raios $\mathrm{X}$ do concentrado de óxidos de ferro da amostra coletada em um dos Latossolos Vermelho-Amarelos avaliados no presente trabalho (amostra 8), pode-se notar uma nítida individualização dos reflexos referentes aos planos cristalográficos 104 da hematita $\left(\mathrm{Hm}_{104}\right)$ e $130 \mathrm{da}$ goethita $\left(\mathrm{Gt}_{130}\right)$. Esse fato pode ser devido, como sugerido por Pötter \& Kämpf (1981), à elevada substituição por Al observada na estrutura da goethita presente naquela amostra.

Apesar da ausência de correlação verificada entre os teores de gibbsita e a substituição por Al na estrutura da goethita, bem como entre os índices Ki e $\mathrm{Kr}$ e a referida substituição, a amostra 8 é a mais gibbsítica dentre todas as amostras avaliadas, fator que, provavelmente, é responsável pela maior incorporação de Al na estrutura da goethita presente nessa amostra, correspondendo ao verificado para outros solos gibbsíticos por Schwertmann \& Latham (1986) e Kämpf \& Schwertmann (1995).

Considerando-se que o pico de máxima intensidade da maghemita refere-se ao espaçamento basal do plano 313 e que este é idêntico ao do plano 110 da hematita, a presença do referido óxido de ferro magnético foi constatada apenas em alguns Latossolos derivados de basalto (amostras 1, 2, 3 e 4) a partir do reflexo referente ao plano cristalográfico $220\left(\mathrm{Mgh}_{220}\right)(\mathrm{d}=0,295 \mathrm{~nm})$, o que concorda com o observado por Fontes \& Weed (1991) para Latossolos do Triângulo Mineiro. 
A presença de maghemita verificada apenas para os solos mais hematíticos do conjunto avaliado é coerente com a tendência geral observada para os solos das regiões tropicais e subtropicais. Nesses solos, geralmente não se observa a presença de maghemita associada a elevados teores de goethita, fato que, segundo Schwertmann (1985), pode estar associado à ausência nesses solos de condições pedoclimáticas favoráveis à formação de maghemita ou até mesmo a uma possível transformação desse mineral em goethita.

Como apresentado nas Figuras 5a, 5e, 6a, 6b, 6c e 6d e como também verificado por Kämpf \& Schwertmann (1982), o tratamento com NaOH $5 \mathrm{~mol} \mathrm{~L}^{-1}$ promoveu, além da concentração dos óxidos de ferro, a concentração de argilominerais do tipo 2:1 como a ilita. Embora a presença desse mineral tenha sido detectada na fração argila desferrificada de três Argissolos (amostras 12, 13 e 14) (Figuras 3b, 3c e 3d), sua ocorrência foi também verificada tanto no concentrado de óxidos de ferro daqueles solos (Figuras $6 b, 6 c$ e $6 d$ ) quanto nos de um Latossolo (amostra 6) (Figura 5a) e de dois Argissolos (amostras 10 e 11) (Figuras 5e e 6a). A presença de ilita em Latossolos foi também verificada por Netto (1996) que, a exemplo do verificado no presente trabalho e no de Alleoni (1996), também detectou a presença desse mineral na fração argila de alguns Argissolos brasileiros.

Finalmente, a análise dos difratogramas de raios $X$ dos concentrados de óxidos de ferro permite verificar que tanto a hematita como a goethita foram os óxidos de ferro cristalinos predominantes nas frações argila da maioria das amostras avaliadas. Esse aspecto foi utilizado como premissa para a semiquantificação desses óxidos realizada com o emprego do método da alocação.

\subsubsection{Análises semiquantitativas}

O critério derivado da proposição de Resende \& Santana (1988) para a classificação dos Latossolos em cauliníticos e oxídicos, com base nos valores do índice Kr (Embrapa, 1999), apresentou-se coerente com a estimativa realizada para a composição mineralógica quantitativa da fração argila das amostras estudadas, apresentada na Tabela 5. Mesmo estendendo-se esse critério para o Nitossolo, para o Neossolo e para os Argissolos estudados, verifica-se que, com exceção do Argissolo 
Vermelho-Amarelo Eutrófico (amostra 14), todas as amostras com $\mathrm{Kr}>0,75$ apresentam mais da metade de suas frações argila constituídas por caulinita (amostras $6,7,9,10,11,12,13$ e 15). Por outro lado, as amostras cujas somas dos teores de gibbsita, goethita e hematita na fração argila foram maiores que $500 \mathrm{~g} \mathrm{~kg}^{-1}$ (amostras 1, 2, 3, 4, 5 e 8) apresentaram $\mathrm{Kr}<0,75$. O Argissolo Vermelho-Amarelo Eutrófico (amostra 14) apresenta o menor grau de intemperismo no conjunto de solos avaliados $(\mathrm{Ki}=2,13)$ e, como evidenciado tanto nos difratogramas de raios $\mathrm{X}$ (Figuras $3 \mathrm{~d}$ e $6 \mathrm{~d}$ ) como nos dados apresentados na Tabela 5 , há expressiva presença de argilominerais do tipo 2:1 (ilita e VHE) na fração argila do mesmo. Assim sendo, a utilização do índice $\mathrm{Kr}$ para a avaliação indireta da composição mineralógica da fração argila desse solo não seria adequada.

Os valores da relação $\mathrm{Hm} / \mathrm{Hm}+$ Gt obtidos para os solos avaliados (Tabela 5) apresentaram adequação ao critério proposto por Kämpf et al. (1988) para a classificação dos Latossolos quanto à predominância relativa de hematita e goethita. Similarmente ao observado para o índice $\mathrm{K}$, a aplicação desse critério apresentou coerência não apenas para os Latossolos mas, também, para a maioria dos demais solos avaliados. Desse modo, as amostras referentes a três Latossolos (amostras 5, 6 e 8 e 8) e a três Argissolos (amostras 10, 12 e 14) são classificadas como goethíticas, uma vez que os valores de $\mathrm{Hm} / \mathrm{Hm}+\mathrm{Gt}$ determinados nas mesmas são menores que 0,2 ; por outro lado, os Latossolos Vermelhos (amostras 1, 2, 3 e 4), cujos valores de $\mathrm{Hm} / \mathrm{Hm}+\mathrm{Gt}$ são maiores que 0,6 , são considerados hematíticos.

À exceção do Argissolo Vermelho Distrófico (amostra 13), que é classificado como criptogoethítico $(0,2>\mathrm{Hm} / \mathrm{Hm}+\mathrm{Gt}>0,6)$, os demais solos não contemplados nas classificações anteriores (amostras 7, 9 e 11) apresentaram valores de $\mathrm{Hm} / \mathrm{Hm}+\mathrm{Gt}$ iguais aos dos limites estabelecidos para a diferenciação dos solos em goethíticos, criptogoethíticos e hematíticos. Assim, apesar da falta de uma definição mais precisa e considerando-se os teores de goethita e hematita da fração argila desses solos, tanto 0 Latossolo Vermelho-Amarelo quanto o Argissolo Vermelho-Amarelo (amostras 7 e 11) tendem a apresentarem-se com goethíticos ao passo que o Nitossolo Vermelho Eutrófico poderia ser considerado hematítico.

Embora o uso da relação $\mathrm{Hm} / \mathrm{Hm}+\mathrm{Gt}$ tenha sido preconizado para a avaliação de dados obtidos para amostras coletadas no horizonte B de Latossolos, a aplicação 
Tabela 5. Resultados das análises mineralógicas semiquantitativas da fração argila dos solos estudados, temperaturas de desidroxilação da caulinita $\left(T D_{C}\right)$ e da gibbsita $\left(T D_{G}\right)$, relação $\mathrm{Hm} / \mathrm{Hm}+\mathrm{Gt}$ e estimativas das substituições por alumínio nas estruturas da hematita $\left(S I_{H m}\right)$ e da goethita $\left(S I_{G t}\right)$.

\begin{tabular}{|c|c|c|c|c|c|c|c|c|c|c|c|c|c|}
\hline \multirow[t]{2}{*}{ Núm. } & \multirow[t]{2}{*}{ Classe } & Caulinita & $\mathrm{TD}_{\mathrm{c}}$ & Gibbsita & $\mathrm{TD}_{\mathrm{G}}$ & Hematita & Goethita & Ferrihidrita & $\mathrm{Al}(\mathrm{OH})_{3}$ & Outros $^{(1)}$ & \multirow[t]{2}{*}{$\mathrm{Hm} / \mathrm{Hm}+\mathrm{Gt}$} & $\mathrm{SlHm}_{\mathrm{Hm}}$ & Slat \\
\hline & & $\mathrm{g} \mathrm{kg}^{-1}$ & ${ }^{\circ} \mathrm{C}$ & $\mathrm{g} \mathrm{kg}^{-1}$ & ${ }^{\circ} \mathrm{C}$ & 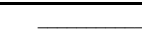 & 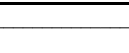 & $\mathrm{g} \mathrm{kg}^{-1}$ & & $\bar{\square}$ & & \multicolumn{2}{|c|}{$\mathrm{mol} \mathrm{mol}^{-1}$} \\
\hline 1 & LVwf & 234,0 & 532,2 & 458,8 & 305,2 & 223,5 & 33,0 & 18,2 & 19,8 & 12,7 & 0,87 & 0,13 & 0,10 \\
\hline 2 & LVef & 405,0 & 537,2 & 244,7 & 300,3 & 204,8 & 37,2 & 14,7 & 16,2 & 77,3 & 0,85 & 0,12 & 0,14 \\
\hline 3 & LVdf & 407,5 & 540,2 & 337,0 & 301,7 & 210,7 & 8,8 & 13,5 & 15,2 & 7,3 & 0,96 & 0,11 & 0,09 \\
\hline 5 & LAw & 296,9 & 529,2 & 356,7 & 301,6 & 0,0 & 207,0 & 5,1 & 17,5 & 116,8 & 0,00 & - & 0,28 \\
\hline 6 & LVd & 522,1 & 542,1 & 119,3 & 299,3 & 23,0 & 110,4 & 6,4 & 12,2 & 206,6 & 0,17 & 0,06 & 0,32 \\
\hline 7 & LVAd & 631,5 & 545,3 & 10,3 & 274,0 & 20,6 & 84,5 & 6,6 & 8,6 & 237,8 & 0,20 & 0,13 & 0,16 \\
\hline 8 & LVAd & 256,1 & 534,1 & 552,6 & 303,3 & 1,9 & 159,8 & 3,0 & 16,2 & 10,4 & 0,01 & 0,08 & 0,40 \\
\hline 9 & NVef & 534,2 & 543,9 & 23,2 & 284,5 & 127,6 & 83,7 & 20,2 & 10,4 & 200,7 & 0,60 & 0,14 & 0,18 \\
\hline 10 & PVAd & 600,5 & 537,3 & 2,4 & 277,3 & 2,7 & 85,2 & 6,0 & 10,7 & 292,5 & 0,03 & 0,03 & 0,27 \\
\hline 11 & PVAd & 773,1 & 546,4 & 0,0 & - & 14,0 & 55,8 & 5,5 & 8,4 & 143,2 & 0,20 & 0,12 & 0,26 \\
\hline 12 & $\mathrm{PVe}$ & 530,2 & 532,1 & 0,0 & - & 23,4 & 124,6 & 16,4 & 13,2 & 292,3 & 0,16 & 0,04 & 0,25 \\
\hline 13 & PVd & 513,2 & 536,7 & 8,6 & 280,8 & 25,5 & 88,7 & 11,0 & 13,7 & 339,3 & 0,22 & 0,10 & 0,20 \\
\hline 14 & PVAe & 281,9 & 524,2 & 2,4 & 260,6 & 10,6 & 52,1 & 13,4 & 20,4 & 619,1 & 0,17 & 0,05 & 0,18 \\
\hline 15 & RQo & 682,6 & 546,4 & 15,9 & 271,6 & 5,6 & 65,8 & 16,2 & 12,4 & 201,6 & 0,08 & 0,01 & 0,08 \\
\hline
\end{tabular}


desse critério para o Neossolo Quartzarênico Órtico, cuja amostra foi coletada em horizonte $\mathrm{C}$, também se mostrou bastante adequada. $\mathrm{O}$ valor menor que 0,2 observado para essa relação, no referido solo, permite classificá-lo como goethítico, o que concorda com os teores de hematita e goethita determinados em sua fração argila (Tabela 5).

Em relação aos teores de óxidos mal cristalizados, foram verificados teores de ferrihidrita que variaram entre 3 (amostra 8) e 20,2 $\mathrm{g} \mathrm{kg}^{-1}$ (amostra 9), com um valor médio de $11,5 \mathrm{~g} \mathrm{~kg}^{-1}$. Já para o óxido de alumínio, verificou-se um teor mínimo de 8,4 e um máximo de 24,3 $\mathrm{g} \mathrm{kg}^{-1}$ (média de 14,6 $\mathrm{g} \mathrm{kg}^{-1}$ ). A aplicação do teste t para amostras independentes não revelou a existência de diferença entre os teores médios dos referidos componentes na fração argila dos solos avaliados.

Análises de correlação linear simples entre o teor de ferrihidrita e os teores de matéria orgânica determinados em todas as amostras (Tabela 2) não revelaram a existência de relação entre esses dois atributos $\left(r=0,21^{\text {ns }}\right)$. Embora ao se considerar apenas os Latossolos tenha-se observado um aumento no valor do coeficiente de correlação $(r=0,57)$, ainda assim não se verificou significância para o mesmo. Nem mesmo ao considera-se a relação $\mathrm{Fe}_{\mathrm{OXA}} / \mathrm{Fe}_{\mathrm{DC}}$ foi possível a observação de uma relação direta entre o acúmulo de ferrihidrita no meio e o teor de matéria orgânica, resultado não corroborado pelo reconhecido efeito inibitório exercido pelos compostos orgânicos sobre a cristalização de óxidos de ferro (Cornell \& Schwertmann, 1996).

Além de avaliações semiquantitativas, a análise térmica diferencial possibilita também a determinação da temperatura de desidroxilação de minerais, que apresenta relação direta com o grau de cristalinidade dos mesmos (Kühnel et al., 1975; Bulens \& Delmon, 1977).

No presente trabalho, os valores da temperatura de desidroxilação (TD) da gibbsita variaram de 260,6 a $307,2{ }^{\circ} \mathrm{C}$; já para a caulinita os valores de TD estiveram entre 524,2 e 546,4 ${ }^{\circ} \mathrm{C}$ (Tabela 5). Tais variações podem sugerir a existência de diferença em natureza que um mesmo mineral pode apresentar quando se comparam amostras provenientes de diferentes materiais de origem e ambientes de formação.

Desconsiderando-se a amostra 14, foi possível verificar a existência de correlação tanto entre a temperatura de desidroxilação da gibbsita $\left(T_{G}\right)$ e os índices 
Ki e Kr ( $r=-0,90^{* *}$ para ambos) quanto entre a temperatura de desidroxilação da caulinita $\left(T D_{C}\right)$ e os referidos índices ( $r=0,70^{* *}$ para ambos).

Embora as relações observadas apresentem-se coerentes com os comportamentos opostos apresentados pela gibbsita e pela caulinita em relação ao efeito do intemperismo sobre seus graus de cristalinidade (Kühnel et al., 1975; Chittleborough \& Walker, 1988) e ainda reiterem a existência de diferenças quanto ao grau de organização cristalina dentro dos conjuntos avaliados no presente trabalho, tais observações devem ser consideradas com ressalvas uma vez que as determinações foram realizadas em misturas de minerais, o que provavelmente possibilitou um efeito de quantidade sobre as emperaturas de desidroxilação. Tal afirmação se baseia nas correlações observadas entre os teores dos minerais e suas temperaturas de desidroxilação $\left(r=0,89^{\star *}\right.$ para a gibbsita e $r=0,83^{\star *}$ para a caulinita $)$. Além disso, não apenas o estádio de intemperismo mas outros fatores como material de origem, profundidade no perfil e regime hídrico do solo podem exercer influência sobre o grau de cristalinidade dos minerais que fazem parte de sua constituição (Kühnel et al., 1975; Chittleborough \& Walker, 1988).

Outra tentativa de se verificar a existência de diferenças estruturais nas caulinitas avaliadas consistiu em se correlacionar os valores de suas temperaturas de desidroxilação e os teores de ferro em seus cristais, os quais foram estimados pelas diferenças entre os teores de ferro do ataque sulfúrico $\left(\mathrm{Fe}-\mathrm{H}_{2} \mathrm{SO}_{4}\right)$ e os teores de ferro extraídos com ditionito-citrato tanto na TFSA ( $\mathrm{Fe}_{\mathrm{DC}}$ - TFSA $)$ como na argila ( $\mathrm{Fe}_{\mathrm{DC}}$ - argila $)$.

Desconsiderando-se novamente a amostra 14, observou-se uma relação inversa entre as variáveis supracitadas, caracterizada por um coeficiente de correlação de $-0,69^{\star *}$ entre a $\mathrm{TD}_{\mathrm{C}}$ e a diferença $\mathrm{Fe}_{2} \mathrm{H}_{2} \mathrm{SO}_{4}-\mathrm{Fe}_{\mathrm{DC}}$ - TFSA e por um coeficiente de $-0,64^{\star *}$ entre a referida propriedade termal e a diferença $\mathrm{Fe}-\mathrm{H}_{2} \mathrm{SO}_{4}-\mathrm{Fe}_{\mathrm{DC}}$ - argila. Tais observações são concordantes com a redução da cristalinidade da caulinita causada pela incorporação de ferro à sua estrutura (Mestdagh et al., 1980). Contudo, assim como verificado para os índices de intemperismo, o teor de caulinita apresentou correlação inversa com o teor de Fe estrutural estimado por ambas as formas acima mencionadas, fato que também sugere que as correlações observadas apresentam acentuada influência do teor de caulinita.

Singh \& Gilkes (1992b) observaram um coeficiente de correlação de -0,60** entre o teor de ferro de caulinitas de solos australianos e a TD das mesmas, 
compatível com o observado no presente trabalho, ainda que considerado com ressalvas. Como mencionado por esses autores, a diminuição da estabilidade térmica da caulinita em decorrência da presença de ferro em sua estrutura deve-se a menor estabilidade térmica apresentada por grupos $\mathrm{Fe}-\mathrm{OH}$ presentes nas lâminas octaedrais da caulinita. Os grupos $\mathrm{Fe}-\mathrm{OH}$ tendem a apresentar características similares a de óxidos de ferro como a goethita e lepidocrocita, cujos valores de TD variam entre 260 e $320{ }^{\circ} \mathrm{C}$ (Cornell \& Schwertmann, 1996); por outro lado, os grupos Al-OH apresentam comportamento semelhante ao de óxidos de alumínio como o diásporo e a bohemita cujas TDs variam entre 450 e $580^{\circ} \mathrm{C}$ (Hsu, 1989).

Em relação à substituição estrutural por alumínio, verificou -se que a mesma variou de 0,01 a 0,14 mol mol ${ }^{-1}$ para as hematitas avaliadas (média de 0,09 mol mol${ }^{-1}$ ) (Tabela 5). Para a goethita, os graus de substituição observados variaram de 0,05 a $0,40 \mathrm{~mol} \mathrm{~mol}^{-1}$, com média de $0,20 \mathrm{~mol} \mathrm{~mol}^{-1}$. O maior grau de substituição normalmente atribuído para a goethita (Pötter \& Kämpf, 1981; Fontes \& Weed, 1991; Prasetyo \& Gilkes, 1994) foi verificado para a maioria das amostras, com exceção das referentes àtrês Latossolos Vermelhos (amostras 1, 3 e 4).

Em média, para as 14 amostras em que ambas as substituições foram observadas, a substituição por Al estimada nas goethitas $\left(\mathrm{Sl}_{\mathrm{Gt}}\right)$ foi 1,4 vezes maior que a estimativa efetuada para as hematitas $\left(S I_{H m}\right)$. Apenas duas amostras (11 e 13) apresentaram goethitas com substituição por alumínio igual ao dobro daquela determinada na hematita. Essa relação é exatamente igual a possível relação 2:1 preconizada para as substituições de goethitas e hematitas coexistentes em uma amostra, a qual é baseada na capacidade teórica da goethita de poder acomodar duas vezes mais Al em sua estrutura que a hematita (Schwertmann \& Kämpf, 1985).

Embora se considere o valor de $0,33 \mathrm{~mol} \mathrm{~mol}^{-1}$ como limite teórico para a substituição por Al na goethita (Schwertmann, 1985), uma das goethitas avaliadas no presente trabalho apresentou substituição 0,07 unidades maior que o limite supracitado. Como mencionado anteriormente, a amostra que apresentou essa substituição é a mais gibbsítica centre todas as estudadas, razão, provavelmente, responsável pela maior substituição determinada para a goethita nela presente. De modo semelhante ao observado para essa amostra, valores maiores que 0,33 mol mol $\mathrm{m}^{-1}$ para a substituição por alumínio na estrutura da goethita foram observados por Schwertmann \& Kämpf (1985) para solos gibbsíticos do Planalto 
Central $\left(0,36 \mathrm{~mol} \mathrm{~mol}^{-1}\right)$ e por Singh \& Gilkes (1992a) para solos australianos $(0,35 \mathrm{~mol}$ $\left.\mathrm{mol}^{-1}\right)$.

Apesar de no presente trabalho não haver dados suficientes para considerações baseadas em maiores evidências, as amplitudes verificadas tanto para a $\mathrm{Sl}_{H \mathrm{~m}}$ como para a $\mathrm{Sl}_{\mathrm{Gt}}$ podem se refletir em diferenças quanto a propriedades intrínsecas desses minerais, tais como tamanho médio dos cristalitos, superfície específica e estabilidade estrutural (Schulze \& Schwertmann, 1984; Kämpf \& Schwertmann, 1995). Desse modo, é provável que tanto as hematitas quanto as goethitas avaliadas no presente trabalho apresentem variabilidade comportamental em relação à mani festação de suas propriedades eletroquímicas e capacidades de adsorção iônica.

\subsection{Caracterização eletroquímica}

\subsubsection{Ponto de Efeito Salino Nulo}

\subsubsection{Determinação analítico-computacional a partir de dados de titulação potenciométrica}

O PESN é normalmente determinado por meio de gráficos construídos a partir de resultados experimentais de titulação potenciométrica, sendo igual ao valor de $\mathrm{pH}$ correspondente ao ponto de interseção de curvas estabelecidas para diferentes concentrações salinas. Essas curvas relacionam as quantidades de íons $\mathrm{H}^{\mathrm{e} \mathrm{OH}^{-}}$ adsorvidos por subamostras de solo aos valores de $\mathrm{pH}$ atingidos pelas suspensões na condição de equilíbrio (Raij \& Peech, 1972). Teoricamente, todas as curvas de titulação potenciométrica deveriam se cruzar em um mesmo ponto, contudo, em geral isso não ocorre. Em alguns casos, pode-se observar mais de um ponto de interseção entre as curvas traçadas, especialmente quando a determinação do PESN é efetuada em amostras provenientes de solos menos intemperizados.

A utilização de planilhas eletrônicas para a elaboração das curvas de titulação potenciométrica e a subseqüente determinação manual do ponto de cruzamento das mesmas reduzem a subjetividade existente na determinação convencional do valor do 
PESN. Contudo, mesmo com esse procedimento, um tempo considerável é necessário para a determinação do PESN nos casos em que um grande número de amostras é analisado. Nesse contexto, procurou-se, no presente trabalho, elaborar um procedimento de cálculo para o tratamento de dados de titulação potenciométrica que, uma vez implementado sob a forma de um aplicativo computacional, possibilitasse a determinação rápida e não subjetiva do valor do PESN de amostras de solo e, ao mesmo tempo, permitisse a avaliação do grau de precisão dos valores calculados.

A primeira etapa do desenvolvimento do método consistiu na identificação de uma relação funcional existente entre as variáveis medidas na etapa de titulação potenciométrica, ou seja, entre os valores de $\mathrm{pH}$ das suspensões e as quantidades adsorvidas de $\mathrm{H}^{+}$e $\mathrm{OH}^{-}$pelas amostras de solo nas diferentes séries eletrolíticas. A função ideal deveria ser aplicável a vários tipos de solos, que deveriam apresentar ampla variação quanto aos atributos que exercem influência sobre o PESN, e a todas as séries eletrolíticas comumente utilizadas no método potenciométrico. Além desses aspectos, seria desejável que o modelo em questão não oferecesse grande dificuldade computacional tanto para o seu ajuste matemático quanto para o cálculo de suas raízes.

Os dados de titulação potenciométrica das amostras avaliadas no presente trabalho foram utilizados para o ajuste de várias equações empregando-se o software Table Curve ${ }^{\circledR}$. O ajustamento das equações foi efetuado separadamente para cada série eletrolítica, considerando-se o valor de $\mathrm{pH}$ das suspensões como variável dependente das quantidades de $\mathrm{H}^{+}$e $\mathrm{OH}^{-}$adsorvidos pelas subamostras de solo. Esse procedimento permitiu verificar que, dentre as várias equações que se ajustaram ao fenômeno, o modelo polinomial de quarto grau foi o que melhor se adequou aos requisitos estabelecidos para a escolha da relação funcional de interesse.

A observação da Figura 7 permite verificar que não houve influência significativa da heterogeneidade apresentada pelas amostras sobre a adequação do modelo polinomial de quarto grau para a estimativa de valores de $\mathrm{pH}$ a partir das quantidades adsorvidas de $\mathrm{H}^{+}$e $\mathrm{OH}^{-}$. A excelente correspondência obtida entre os valores de $\mathrm{pH}$ medidos e os estimados pelo modelo polinomial de quarto grau foi observada para todas as séries eletrolíticas utilizadas, mesmo considerando-se a variabilidade apresentada pelo conjunto de solos no que se refere aos atributos relacionados direta ou inversamente ao PESN como o grau de intemperismo, 
avaliado pelo índice $\mathrm{Ki}$, os teores de caulinita, e a soma dos teores de gibbsita, hematita e goethita.

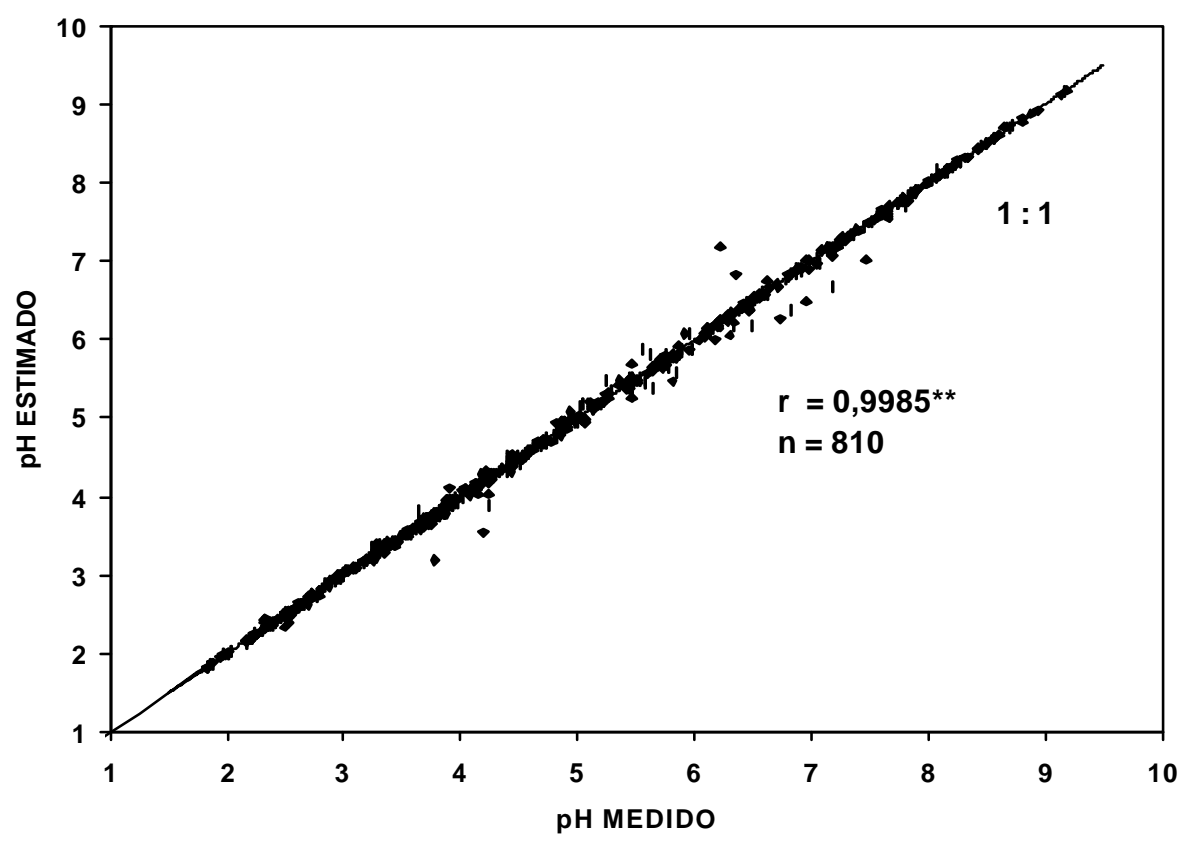

Figura 7 - Relação entre os valores medidos de $\mathrm{pH}$ e os estimados pelo modelo polinomial de quarto grau $\left(\mathrm{pH}=\mathrm{a}+\mathrm{bx}+\mathrm{cx}^{2}+\mathrm{dx}^{3}+\mathrm{ex}^{4}\right.$, sendo $\mathrm{x}=\mathrm{H}^{+}$ou $\mathrm{OH}^{-}$adsorvidos).

Uma vez definida a equação representativa das curvas de titulação potenciométrica, procedeu-se àelaboração de um procedimento de cálculo visando -se à determinação do valor do PESN. Em seguida, um programa computacional foi implementado, utilizando-se o sistema de desenvolvimento de aplicativos Borland Delphi Standard $3.0^{\circledR}$, para a realização das operações e apresentação dos resultados.

A partir das concentrações molares de $\mathrm{H}^{+}$e de $\mathrm{OH}^{-}$nas soluções salinas, do volume dessas soluções nos recipientes (ou dos volumes de ácido e de base adicionados às soluções salinas conforme método utilizado por Costa et al., 1984) e da 
massa de solo utilizada para as determinações, o programa realiza o cálculo das quantidades de íons $\mathrm{H}^{+}$e $\mathrm{OH}^{-}$adsorvidos pelas amostras, expressas em mmol $\mathrm{kg}^{-1}$ de solo. Em seguida, utilizando esses valores calculados e os valores de $\mathrm{pH}$ atingidos pelas suspensões, o sistema efetua o ajustamento da equação polinomial do quarto grau para cada série eletrolítica segundo o método dos quadrados mínimos. Para tanto, o programa gera um sistema de equações normais, que no caso de um polinômio de quarto grau, consiste em um sistema linear constituído por cinco equações e cinco incógnitas, e o soluciona com o emprego do método do escalonamento.

Ao considerar-se a determinação gráfica do PESN, verifica-se que o ponto de cruzamento entre duas curvas de titulação potenciométrica corresponde a um valor comum de $\mathrm{pH}$ para ambas as séries eletrolíticas envolvidas. Desse modo, considerando-se que a determinação do PESN envolve normalmente três séries eletrolíticas, pode-se determinar separadamente três valores de $\mathrm{pH}$ referentes aos pontos de cruzamento das curvas de titulação potenciométrica tomadas duas a duas. Teoricamente, esses três valores deveriam ser iguais, contudo, nem sempre isso se verifica.

Adotando-se a abordagem analítica com a descrição das curvas de titulação potenciométrica pelo polinômio de quarto grau, verifica-se que cada um dos três pontos de cruzamento supracitados pode ser calculado subtraindo-se os respectivos coeficientes das equações ajustadas, tomadas aos pares, determinando-se a raiz da equação resultante e substituindo-se o valor encontrado em qualquer dos polinômios do par considerado.

O programa efetua as subtrações dos coeficientes das equações ajustadas gerando três novas equações cujas raízes são calculadas iterativamente com o emprego do método de Newton-Raphson. Em seguida, para cada par de equações considerado, o valor encontrado para a raiz é substituído em uma das equações polinomiais que geraram a equação solucionada, resultando no cálculo do valor parcial do PESN. Finalmente, o programa calcula a média aritmética dos três valores parciais encontrados, que corresponde à estimativa do PESN. A precisão do valor calculado pode ser avaliada pela observação dos valores do desvio-padrão e do coeficiente de variação da estimativa, que são também calculados e apresentados. 
Embora a equação polinomial de quarto grau proporcione excelente concordância entre os valores de $\mathrm{pH}$ medidos e estimados, esse modelo apresenta a desvantagem de poder admitir até quatro valores distintos para as suas raízes. Esse fato poderia resultar na obtenção de valores incorretos para o PESN, visto que, dependendo da proximidade dos valores das diferentes raízes e do valor inicial utilizado para as iterações, poderá haver convergência para valores diferentes daquele que corresponde ao ponto de interseção de interesse. Para contornar esse problema, o sistema define a amplitude mínima comum de quantidades adsorvidas de $\mathrm{H}^{+}$e $\mathrm{OH}^{-}$ para as três concentrações salinas e, em seguida, realiza uma série de substituições do início ao fim do intervalo gerado, com incrementos de $0,5 \mathrm{mmol}_{\mathrm{c}} \mathrm{kg}^{-1}$ de $\mathrm{H}^{+} / \mathrm{OH}^{-}$, em cada equação gerada pelas subtrações de coeficientes. Desse modo, é possível identificar as quantidades adsorvidas de $\mathrm{H}^{\mathrm{ou}} \mathrm{OH}^{-}$que geram os quatro menores valores absolutos para as diferenças entre valores de $\mathrm{pH}$ nas duas séries eletrolíticas consideradas. Os valores encontrados são utilizados para o início das iterações do método de Newton-Raphson resultando no cálculo de quatro raízes, que poderão ser iguais ou diferentes. A substituição de cada um desses valores em uma das duas equações polinomiais, cujos coeficientes foram subtraídos, possibilita o cálculo de quatro valores parciais de PESN para cada concentração salina. Esses quatro valores são combinados levando-se em consideração as três séries eletrolíticas e sessenta e quatro valores médios para o PESN são calculados. Das médias calculadas, o valor do PESN corresponderá àquela associada ao menor coeficiente de variação. Com esse procedimento, além de se evitar a determinação de valores errôneos de PESN devido ̀̀ razões acima mencionadas pode -se, em alguns casos, contornar o problema da existência de mais de um ponto de cruzamento entre as curvas de titulação potenciométrica, visto que um valor mínimo para o coeficiente de variação, como critério de seleção da média, implica na máxima proximidade dos três valores parciais de PESN.

Após o estabelecimento da rotina de cálculo, valores de PESN foram calculados com o uso do programa a partir de dados experimentais de titulação potenciométrica extraídos dos trabalhos de Alleoni (1992) e Dynia (1993). Esses valores foram então comparados aos apresentados nos trabalhos consultados, que foram determinados pelos referidos autores com o emprego do método gráfico manual. Adicionalmente, efetuou-se a determinação gráfica dos valores de PESN a 
partir dos mesmos dados de titulação potenciométrica supracitados utilizando-se o programa Microsoft Excel $2000^{\circledR}$. Os valores de PESN obtidos por esse procedimento foram também comparados aos obtidos pelo método analítico-computacional.

Os valores de PESN calculados pelo programa a partir dos dados de titulação potenciométrica apresentados nos trabalhos de Alleoni (1992) (amostras 1 a 11) e Dynia (1993) (amostras 12 a 26), os valores obtidos pelos referidos autores com o método gráfico manual e os determinados graficamente com o uso de planilha eletrônica são apresentados na Tabela 6. A observação dos dados contidos nessa Tabela permite verificar que a maior diferença observada entre os valores calculados e os determinados manualmente foi de 0,39 unidades de $\mathrm{pH}$. Ao comparar-se os valores calculados com os determinados em planilha eletrônica verificou-se que a maior diferença entre eles foi de 0,22 unidades de $\mathrm{pH}$.

Considerando-se os 26 conjuntos de dados avaliados, pode-se notar que os valores de PESN calculados pelo programa apresentaram elevada correlação $\left(r=0,99^{\star \star}\right)$ tanto com valores obtidos pelo método gráfico manual quanto com aqueles obtidos a partir de gráficos gerados em planilha eletrônica. Por outro lado, a comparação dos desvios médios referentes às diferenças entre o método analítico e os métodos gráficos, efetuada com a aplicação do teste t para amostras independentes, demonstrou que a média dos desvios observados entre os valores de PESN calculados e os determinados pelo método gráfico manual, que apresenta maior subjetividade, foi significativamente maior $(p<0,05)$ que a média dos desvios observados entre os valores de PESN calculados e os obtidos a partir de gráficos elaborados em planilha eletrônica. 
Tabela 6. Valores do PESN de amostras de solo obtidos a partir do método gráfico convencional e calculados pelo programa, precisão dos valores calculados e valores das diferenças observadas entre os dois métodos de determinação.

\begin{tabular}{|c|c|c|c|c|c|c|}
\hline Amostra & PESN gráfico ${ }^{(1)}$ & PESN gráficos ${ }^{(2)}$ & PESN calculado ${ }^{(3)}$ & C.V. $(\%)^{(4)}$ & Desvio $_{1}{ }^{(5)}$ & Desvio $_{2}{ }^{(6)}$ \\
\hline 1 & 3,70 & 3,61 & 3,50 & 3,88 & 0,20 & 0,11 \\
\hline 2 & 3,50 & 3,44 & 3,30 & 3,60 & 0,20 & 0,14 \\
\hline 3 & 3,50 & 3,39 & 3,30 & 1,37 & 0,20 & 0,09 \\
\hline 4 & 3,50 & 3,45 & 3,40 & 2,36 & 0,10 & 0,05 \\
\hline 5 & 3,50 & 3,45 & 3,40 & 0,77 & 0,10 & 0,05 \\
\hline 6 & 3,80 & 3,78 & 3,60 & 2,48 & 0,20 & 0,18 \\
\hline 7 & 3,80 & 3,70 & 3,60 & 1,82 & 0,14 & 0,10 \\
\hline 8 & 3,70 & 3,70 & 3,50 & 3,54 & 0,29 & 0,20 \\
\hline 9 & 3,80 & 3,86 & 3,70 & 4,72 & 0,10 & 0,16 \\
\hline 10 & 3,80 & 3,86 & 3,70 & 4,78 & 0,10 & 0,16 \\
\hline 11 & 4,60 & 4,35 & 4,30 & 7,01 & 0,30 & 0,05 \\
\hline 12 & 4,50 & 4,42 & 4,20 & 7,01 & 0,30 & 0,22 \\
\hline 13 & 4,40 & 4,21 & 4,10 & 6,20 & 0,30 & 0,11 \\
\hline 14 & 4,30 & 4,31 & 4,10 & 6,51 & 0,20 & 0,21 \\
\hline 15 & 4,40 & 4,48 & 4,30 & 8,53 & 0,10 & 0,18 \\
\hline 16 & 3,65 & 3,62 & 3,62 & 3,64 & 0,03 & 0,00 \\
\hline 17 & 3,60 & 3,65 & 3,62 & 2,87 & $-0,02$ & 0,03 \\
\hline 18 & 3,65 & 3,65 & 3,70 & 2,63 & $-0,05$ & $-0,05$ \\
\hline 19 & 6,15 & 5,98 & 5,95 & 8,13 & 0,20 & 0,03 \\
\hline 20 & 3,60 & 3,55 & 3,60 & 1,28 & 0,00 & $-0,05$ \\
\hline 21 & 5,65 & 5,52 & 5,50 & 2,64 & 0,10 & $-0,03$ \\
\hline 22 & 3,40 & 3,37 & 3,38 & 2,69 & 0,02 & $-0,03$ \\
\hline 23 & 5,80 & 5,68 & 5,66 & 4,94 & 0,14 & 0,02 \\
\hline 24 & 3,35 & 3,28 & 3,30 & 3,43 & 0,05 & $-0,02$ \\
\hline 25 & 3,40 & 3,40 & 3,41 & 2,23 & $-0,01$ & $-0,01$ \\
\hline 26 & 6,05 & 5,72 & 5,66 & 5,61 & 0,39 & 0,06 \\
\hline Média & 4,12 & 4,06 & 3,98 & - & 0,14 & 0,09 \\
\hline Desvio padrão & 0,86 & 0,80 & 0,81 & - & - & - \\
\hline
\end{tabular}

(1) Valores de PESN apresentados nos trabalhos de Alleoni (1992) - amostras 1 a 11 - e de Dynia (1993) - amostras 12 a 26.

(2) PESN referente àmédia dos valores de $\mathrm{pH}$ correspondentes aos pontos de cruzamento das curvas de titulação potenciométrica tomadas duas a duas sendo os gráficos elaborados em planilha eletrônica.

(3) PESN calculado com o método analítico-computacional.

(4) Coeficiente de variação associado aos valores calculados de PESN.

(5) Desvia $=$ PESN gráfico $1-P E S N$ calculado.

(6) Desviq $=$ PESN gráfico $2-\mathrm{PESN}$ calculado . 
A avaliação das análises comparativas demonstrou que o método analíticocomputacional proposto mostrou-se bastante adequado para a determinação do valor do PESN de amostras de solo visto que os valores gerados foram bastante próximos dos obtidos com o método gráfico convencional. Além disso, o sistema proporcionou rapidez e ausência de subjetividade àdeterminação do valor do PESN.

O programa desenvolvido, cujo aspecto geral é apresentado na Figura 8, funciona em computadores IBM/PC e compatíveis, e requer como configuração mínima: sistema operacional Windows 95, processador 80486, memória RAM de 16 MB, 2 MB de espaço livre no disco rígido e monitor VGA.
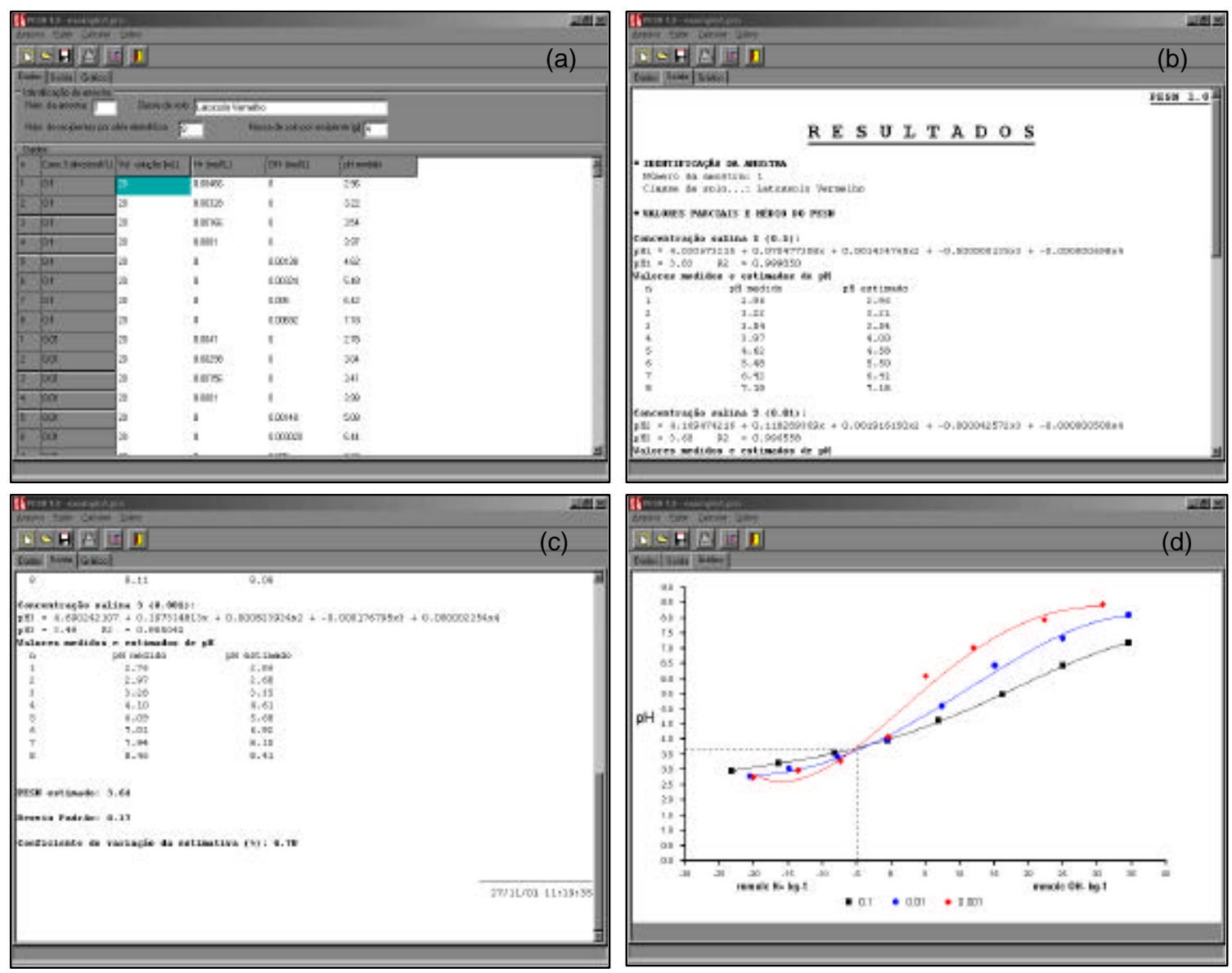

Figura 8 - Aspecto geral do programa computacional para a determinação analítica do PESN a partir de dados de titulação potenciométrica. (a) = módulo de entrada de dados, (b) e (c) = apresentação dos resultados de cálculo, (d) = apresentação dos pontos experimentais, das curvas de titulação potenciométrica ajustadas e do ponto de interseção calculado. 
Os dados de entrada consistem nos seguintes itens: número da amostra, classe de solo, valores das concentrações salinas das séries eletrolíticas, massa de subamostra nos recipientes, concentrações de $\mathrm{H}^{+}$e $\mathrm{OH}^{-}$nas soluções salinas e volume das soluções nos recipientes. O programa adapta-se também ao método de titulação potenciométrica utilizado por Costa et al. (1984) no qual são adicionados pequenos volumes de ácido e base, com concentrações conhecidas, æ̀s soluções salinas contidas nos recipientes.

Além da estimativa do PESN, o programa apresenta as equações de regressão ajustadas para cada série eletrolítica e seus respectivos coeficientes de determinação, os valores medidos e estimados de $\mathrm{pH}$, os valores parciais de PESN e um gráfico, no qual são apresentados os pontos experimentais para cada concentração salina e as respectivas curvas de titulação potenciométrica elaboradas segundo as equações de regressão ajustadas. A apresentação gráfica dos resultados associada ao conhecimento do coeficiente de variação da estimativa permite uma melhor avaliação da precisão do valor obtido para o PESN. Além da visualização dos resultados na tela do computador é possível também a impressão dos resultados analíticos e do gráfico.

\subsubsection{Estimativa do PESN a partir de dados de pH}

A utilização da equação proposta por Keng \& Uehara (1974) mostrou-se bastante adequada para a estimativa do PESN das amostras avaliadas (Tabela 7), haja vista a acentuada correlação verificada entre os valores de PESN estimados pela referida equação e os valores determinados com o tratamento analítico-computacional dos dados de titulação potenciométrica $\left(r=0,96^{\star *}\right)$. Além de reiterar a viabilidade do uso dos valores de $\mathrm{pH}$ medidos em solução de $\mathrm{KCl}$ e em água para a estimativa do PESN de amostras de solo, a acentuada correlação observada também reforça a viabilidade do emprego do método computacional desenvolvido nesse estudo para o tratamento analítico de dados de titulação potenciométrica com vistas à determinação do PESN.

A análise dos resultados apresentados na Tabela 7 permite verificar que a maior discrepância entre os valores estimados e determinados do PESN ocorreu para o Argissolo Vermelho Distrófico, cuja amostra apresenta o maior teor de $\mathrm{Al}^{3+}$ trocável 
dentre todas as amostras avaliadas. O baixo valor do PESN, estimado para essa amostra a partir da equação de Keng \& Uehara (1974), deve-se principalmente ao abaixamento do $\mathrm{pH}$ da suspensão devido à hidrólise promovida por íons $\mathrm{Al}^{3+}$ deslocados da fase sólida após o contato com a solução de $\mathrm{KCl} 1 \mathrm{~mol} \mathrm{~L}^{-1}$.

Assim como observado na determinação do PESN a partir de dados de titulação potenciométrica, o uso de soluções salinas mais concentradas tende a subestimar o valor do PESN de amostras de solo, sobretudo naquelas mais ricas em $\mathrm{Al}^{3+}$ (Sakurai et al., 1989a). Embora o uso da solução de $\mathrm{KCl} 1 \mathrm{~mol} \mathrm{~L}^{-1}$ tenha permitido a obtenção de estimativas do PESN bastante próximas dos valores determinados para a maioria das amostras, é muito provável que estimativas ainda melhores seriam obtidas com a equação de Keng \& Uehara se valores de pH medidos em solução mais diluída, como a de $\mathrm{KCl} 0,5 \mathrm{~mol} \mathrm{~L}^{-1}$, fossem utilizados na referida equação juntamente com os valores de $\mathrm{pH} \mathrm{H}_{2} \mathrm{O}$, assim como verificado por Abrahão et al., 1995.

Tabela 7. Valores de pH e PESN das amostras avaliadas

\begin{tabular}{rrrrrl}
\hline Solo & Classe & $\mathrm{pH} \mathrm{H}_{2} \mathrm{O}$ & $\mathrm{pH} \mathrm{KCl}$ & PESN $^{(1)}$ & PESN $^{(2)}$ \\
\hline 1 & LVwf & 5,22 & 5,33 & 5,57 & 5,44 \\
2 & LVef & 6,57 & 5,80 & 5,77 & 5,03 \\
3 & LVdf & 4,57 & 4,49 & 4,47 & 4,41 \\
4 & LVwf & 5,50 & 5,86 & 6,07 & 6,22 \\
5 & LAw & 5,69 & 6,56 & 6,96 & 7,43 \\
6 & LVd & 5,48 & 4,65 & 4,10 & 3,82 \\
7 & LVAd & 5,47 & 4,53 & 3,46 & 3,59 \\
8 & LVAd & 5,32 & 4,90 & 4,50 & 4,48 \\
9 & NVef & 5,97 & 5,34 & 4,80 & 4,71 \\
10 & PVAd & 4,96 & 3,84 & 2,89 & 2,72 \\
11 & PVAd & 4,72 & 3,96 & 3,47 & 3,20 \\
12 & PVd & 5,90 & 5,09 & 4,03 & 4,28 \\
13 & PVd & 4,94 & 3,82 & 3,58 & 2,70 \\
14 & PVAe & 5,78 & 4,46 & 3,40 & 3,14 \\
15 & RQo & 4,79 & 4,32 & 3,49 & 3,85 \\
\hline
\end{tabular}

(1) PESN determinado a partir do tratamento analítico-computacional dos dados de titulação potenciométrica (2) $\mathrm{PESN}$ estimado com a equação : $\mathrm{PCZ}=2 \mathrm{pH} \mathrm{KCl}-\mathrm{pH} \mathrm{H}_{\mathrm{O}}$ (Keng \& Uehara, 1974) 


\subsubsection{Relações entre o PESN e o grau de intemperismo dos solos}

Os valores determinados para o PESN das amostras estudadas variaram de 2,89 a 6,96 (Tabela 7), estando os maiores valores associados aos solos mais intemperizados, fato caracterizado pelas acentuadas correlações inversas observadas entre o PESN e os índices $\mathrm{Ki}\left(-0,79^{\star \star}\right)$ e $\mathrm{Kr}\left(-0,84^{\star \star}\right)$, não se considerando nas análises a amostra 14, cuja mineralogia apresenta-se bastante distinta da média das demais amostras avaliadas.

De modo similar ao verificado para as relações entre o PESN e os índices de intemperismo, pôde-se observar que os valores absolutos das diferenças entre os valores de $\mathrm{PESN}$ e de $\mathrm{pH}$, medidos tanto em água $\left(\mathrm{pH} \mathrm{H}_{2} \mathrm{O}\right)$ quanto em $\mathrm{KCl} 1 \mathrm{~mol} \mathrm{~L}^{-1}$ $(\mathrm{pH} \mathrm{KCl})($ Tabela 7$)$, tenderam a diminuir à medida que o grau de intemperismo aumentou. $\mathrm{O}$ valor absoluto da diferença $\mathrm{pH} \mathrm{H}_{2} \mathrm{O}-\mathrm{PESN}$ correlacionou-se de maneira direta com os índices $\mathrm{Ki}$ e $\mathrm{Kr}$ ( $r=0,75^{* *}$ para ambos, $\mathrm{n}=14$ ); já para a diferença $\mathrm{pH} \mathrm{KCl}$ - PESN coeficientes ligeiramente menores foram obtidos para as correlações com os referidos índices $\left(r=0,64^{* *}\right.$ para ambos, $\left.n=14\right)$.

A análise dos dados apresentados na Tabela 7 permite a constatação de que a diferença média absoluta entre os valores de $\mathrm{pH} \mathrm{H}_{\mathbf{L}} \mathrm{O}$ e PESN é praticamente duas vezes maior que a observada para a diferença $\mathrm{pH} \mathrm{KCl} \mathrm{-} \mathrm{PESN.} \mathrm{Tal} \mathrm{fato} \mathrm{se} \mathrm{deve}$ basicamente àacentuada correlação verificada entre o $\mathrm{pH} \mathrm{KCl} \mathrm{e} \mathrm{o} \mathrm{PESN}\left(r=0,94^{\star *}\right)$.

No presente trabalho, $\mathrm{o} \mathrm{pH} \mathrm{KCl}$ apresentou-se inversamente correlacionado tanto com o teor de $\left.A\right|^{3+}\left(r=-0,58^{\star}, n=14\right)$ quanto com $\circ$ grau de saturação por alumínio $\left(r=-0,69^{\star \star}, n=14\right)$, indicando que baixos valores de $\mathrm{pH} \mathrm{KCl}$ devem-se essencialmente a maiores teores de $\mathrm{Al}^{3+}$ no complexo sortivo. Similarmente e apesar da ausência de correlação significativa, dentre as seis amostras nas quais a presença de $A{ }^{3+}$ trocável foi observada, cinco apresentam-se como cauliníticas (amostras 6, 10, 11, 13 e 15). Já, os valores de $\mathrm{pH} \mathrm{KCl}$ apresentaram-se inversamente correlacionados com o teor de caulinita na fração argila dos solos avaliados $\left(r=-0,69^{* *}, n=14\right)$. Relações semelhantes foram observadas por Netto (1996) que pôde constatar também, ao contrário do verificado no presente trabalho, acentuada correlação direta entre os teores de $\mathrm{Al}^{3+} \mathrm{e}$ os teores de caulinita de Latossolos brasileiros. 
Com base nas relações observadas e no fato de que a caulinita, ao contrário da gibbsita, tem sua estabilidade diminuída com o avanço do ntemperismo, podendo funcionar como uma fonte de $\mathrm{Al}^{3+}$ (Lindsay, 1979), pode-se inferir que os baixos valores de $\mathrm{pH} \mathrm{KCl}$ observados nos solos cauliníticos devem-se além da presença de $\mathrm{Al}^{3+}$ a menor capacidade tampão que esses solos apresentam em decorrência da presença expressiva de grupos superficiais silanol $(-\mathrm{SiOH})$, encontrados nas bordas quebradas da caulinita, que nas condições normais de $\mathrm{pH}$, funcionam apenas como doadores de prótons (Schwertmann \& Fechter, 1982; Sparks, 1995; Zhang \& Zhao, 1997). Do mesmo modo, os menores valores de PESN observados para os solos cauliníticos também são devidos à expressiva presença de grupos - $\mathrm{SiOH}$, que são mais facilmente ionizáveis que os grupos -FeOH e -AlOH (Parks, 1965) e que, portanto, estabelecem o equilíbrio com os íons $\mathrm{H}^{+}$da solução em valores mais baixos de $\mathrm{pH}$.

Em sentido oposto ao observado para a caulinita, os óxidos de ferro e alumínio têm seus teores aumentados no solo à medida que o mesmo torna -se mais intemperizado. Como verificado no presente trabalho, os solos mais desenvolvidos praticamente não apresentam alumínio trocável; esse fato associado ao maior efeito tamponante dos grupos -FeOH e - $\mathrm{AlOH}$ presentes nas superfícies dos óxidos, os quais atuam como doadores e receptores de prótons (Sparks, 1995; Zhang \& Zhao, 1997), faz com que os valores de $\mathrm{pH} \mathrm{KCl}$ sejam maiores nesses solos, que também apresentam maior PESN devido à presença mais expressiva dos referidos grupamentos de superfície.

Desse modo, pode-se concluir que, ao menos para os solos mais intemperizados $(\mathrm{Ki}<2,0)$ o aumento do teor de óxidos em decorrência do intemperismo resulta em alterações similares nos valores de PESN e pH fazendo com que, assim como destacado por Hendershot \& Lavkulich (1978), haja uma diminuição progressiva na diferença entre os valores desses atributos à medida que os solos tornam-se mais evoluídos.

\subsubsection{Relações entre o PESN e atributos mineralógicos}

Em relação à influência da composição mineralógica da fração argila sobre o PESN, ao considerar-se apenas relações individuais, cujas dispersões dos dados são 
apresentadas na Figura 9, e excetuando-se como já efetuado em outras etapas desse trabalho a amostra 14, pôde-se verificar que os valores de PESN apresentaram relação direta com os teores de gibbsita $\left(r=0,72^{* *}\right)$ e de óxidos de alumínio mal cristalizados $\left(r=0,77^{\star \star}\right)$ na fração argila dos solos considerados. Em relação à hematita, pode -se notar na Figura 9c que a amostra 5 apresentou comportamento bastante discrepante do observado para o conjunto avaliado. Ao desconsiderar-se essa amostra, obteve-se um significativo incremento no coeficiente de correlação que passou de $0,53^{*}$ para $0,86^{* *}$. Por outro lado, a caulinita contribuiu para a redução dos valores de PESN das amostras, fato que se reflete na correlação inversa observada entre os teores desse mineral na argila e os valores do referido atributo eletroquímico $\left(r=-0,71^{\star \star}\right)$. Não foram observadas correlações significativas entre os teores de goethita e de ferrihidrita das amostras e o PESN.

Embora as correlações observadas para a caulinita, gibbsita e hematita sejam condizentes com as observadas por outros autores para solos brasileiros (Silva et al.; 1996; Netto, 1996), a ausência de uma relação mais clara entre os teores de goethita e de ferrihidrita e o PESN não é concordante com os elevados valores de ponto de carga zero apresentados por esses óxidos (Parks, 1965; Schwertmann \& Fechter, 1982). Contudo, para o caso da ferrihidrita, pode-se verificar pela dispersão dos pontos (Figura 9e) que assim como para a hematita apenas a amostra 5, com um valor mais alto de PESN, apresentou um comportamento discrepante em relação ao conjunto avaliado. A retirada dessa amostra da análise de correlação faz com que o valor de $r$ passe de não significativo para $0,56^{*}$.

Além das considerações referentes à carga do cátion que compõe a estrutura cristalina de um óxido, de seu raio iônico e do número de oxigênios a ele coordenados, fatores que de acordo com Parks (1965) permitem explicar as diferenças de ponto de carga zero observadas entre os diferentes óxidos, outros fatores também devem ser considerados na manifestação final das propriedades eletroquímicas desses compostos, como por exemplo a exposição de faces cristalográficas e a configuração hidroxílica de superfície (Fontes et al., 2001). 

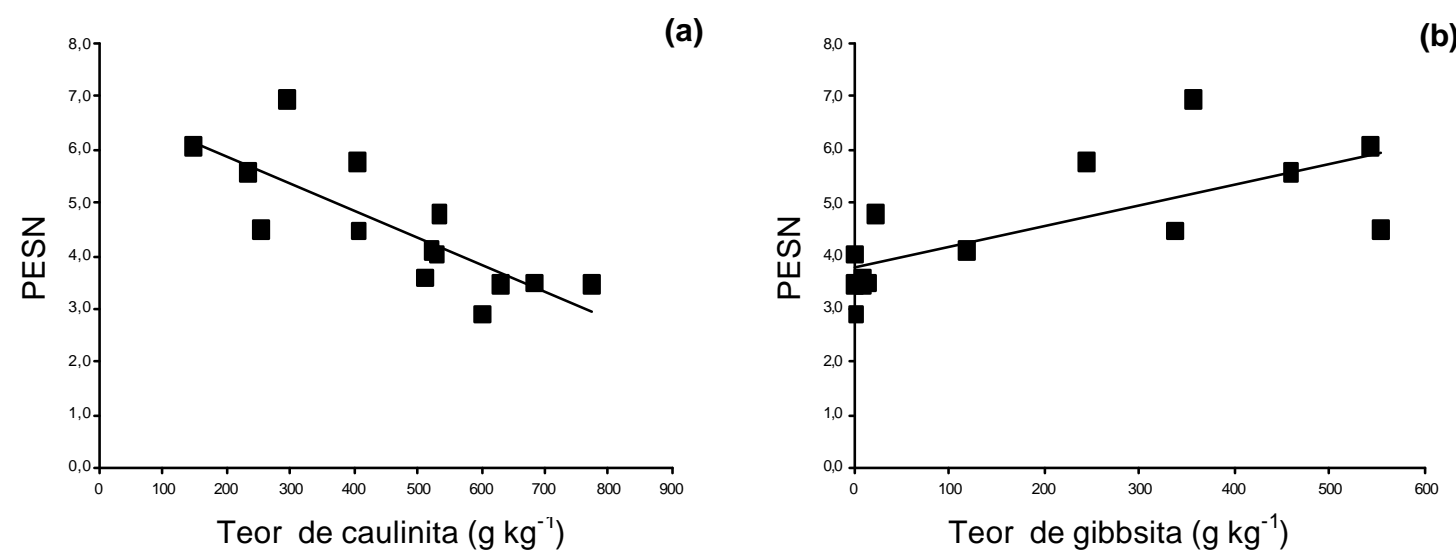

(c)
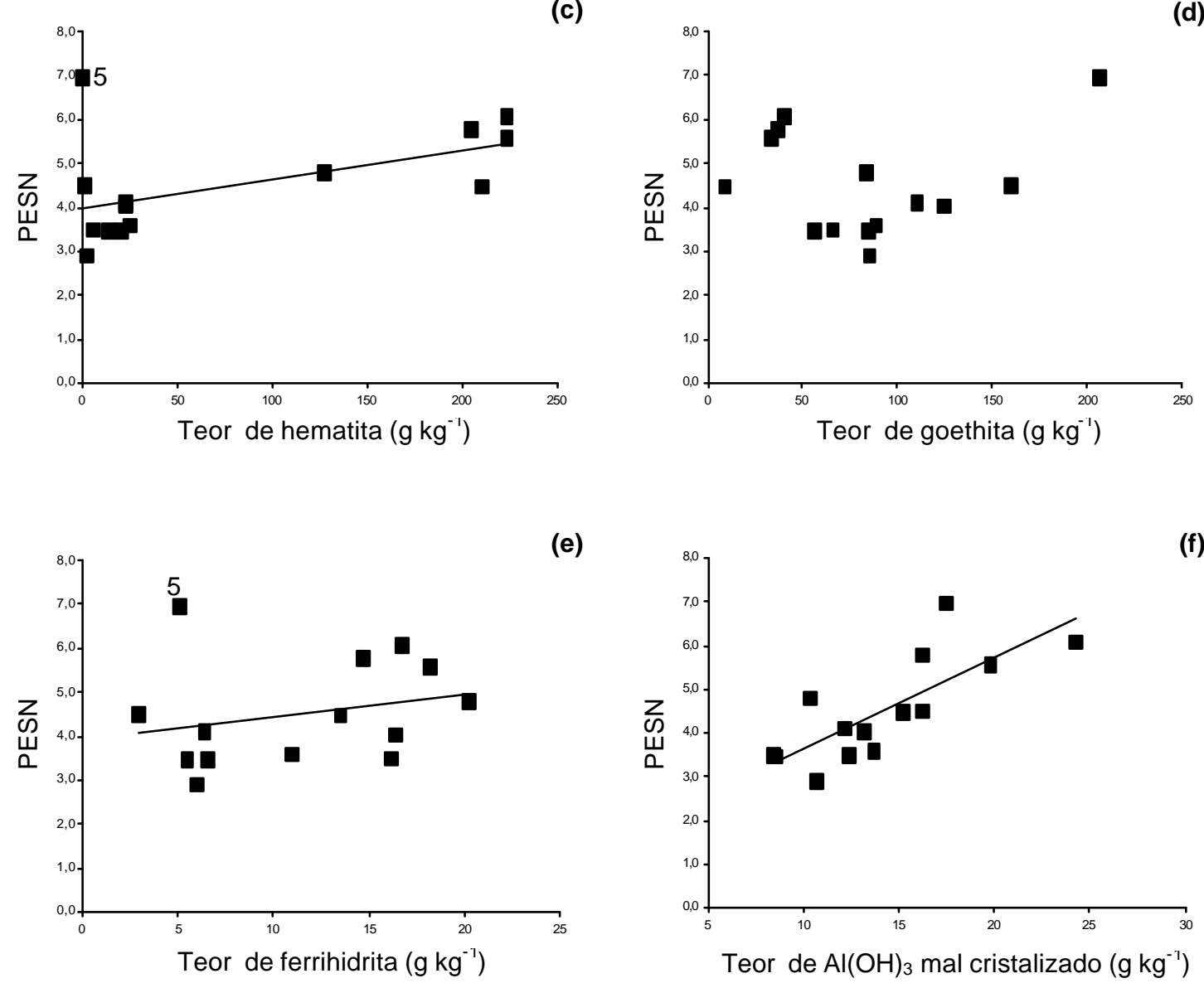

(e)

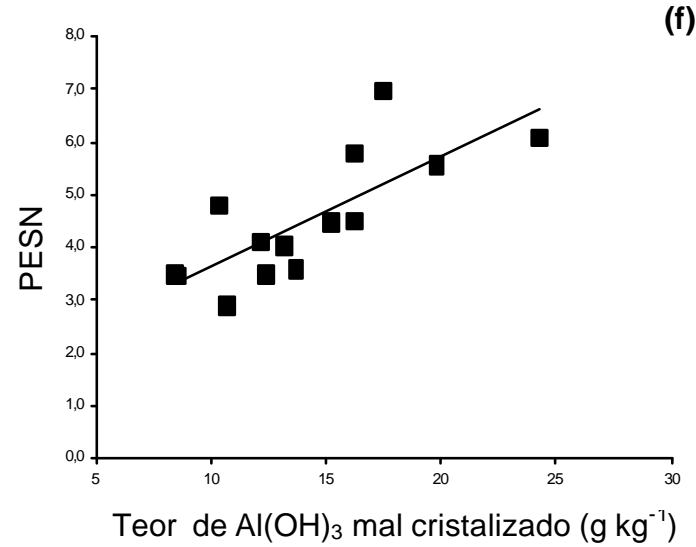

Figura 9 - Relações entre os teores de caulinita (a), gibbsita (b), hematita (c), goethita (d), ferrihidrita (e) e óxido mal cristalizado de alumínio (f) na fração argila e o PESN das amostras avaliadas. 
Desse modo, é possível que a ausência de correlação verificada no presente trabalho entre o PESN e o teor de goethita seja decorrente de diferenças nas propriedades intrínsecas desse mineral, como, por exemplo, quanto à exposição de faces cristalográficas contendo hidroxilas de coordenação simples, dupla e tripla que podem apresentar diferenças relacionadas tanto à tendência à ionização quanto à suscetibilidade àprotonação (Fontes, 2001). Considerações acerca de diferentes graus de recobrimento da goethita por compostos orgânicos (Gillman, 1985) parecem pouco prováveis, haja vista a coexistência de hematita nas amostras e a relação direta observada entre os teores desse mineral e o PESN das amostras.

Dentre os componentes inorgânicos da fração argila avaliados no presente trabalho, merece destaque o óxido mal cristalizado de alumínio, cujos teores foram estimados a partir de dissolução seletiva realizada na fração argila com solução ácida de oxalato de amônio $\left(\mathrm{Al}_{\mathrm{OXA}}\right)$. A análise da Figura $9 \mathrm{f}$ permite verificar uma das melhores distribuições dos pontos experimentais em torno da linha de tendência, a qual demonstra um nítido aumento do PESN em decorrência do incremento no teor do referido óxido, concordando com a acentuada correlação observada por Sakurai et al. (1989b) entre o ponto de carga zero e o teor de $\mathrm{Al}_{\text {OXA }}$ em solos alofânicos do Japão.

Além do nítido efeito observado, deve-se destacar que os teores de $\mathrm{Al}(\mathrm{OH})_{3}$ mal cristalizado foram muito menores que os dos componentes cristalinos semiquantificados na fração argila, fato que reitera tanto a elevada reatividade desses compostos (Bohn et al., 1979) quanto a importância das propriedades intrínsecas dos constituintes da fase sólida para a definição do comportamento eletroquímico do solo.

Em que pese a dificuldade existente na comparação de valores de PCZ disponíveis na literatura para os minerais e óxidos mal cristalizados considerados no presente trabalho, haja vista as diferenças existentes para formas sintéticas e naturais e a influência observada tanto para o método de síntese quanto para o próprio método de determinação sobre o PCZ de um mineral (Parks, 1965; Schwertmann \& Fechter, 1982; Cornell \& Schwertmann, 1996), é provável que a marcante influência dos óxidos mal cristalizados de Al sobre o PESN, como observado no presente estudo, seja decorrente dos elevados valores que os PCZs desses compostos possam apresentar.

Hsu (1989) menciona que os valores de PCZ disponíveis na literatura para os óxidos de alumínio variam de 5,0 a 9,4 e que a maior parte dessas informações é proveniente de estudos com óxidos sintéticos mal cristalizados, sendo pouco 
conhecidos os efeitos da composição e da estrutura dos óxidos sobre seus valores de PCZ. Já para os óxidos de ferro mal cristalizados, valores de PCZ variando entre 5,3 e 7,5 foram encontrados por Schwertmann \& Fechter (1982) para ferrihidritas naturais provenientes de depósitos finlandeses. Em relação aos óxidos cristalinos, Parks (1965), em ampla compilação de cados de PCZ, encontrou valores médios iguais a 5, 6,1 e 6,3 para gibbsitas naturais, hematitas naturais e goethitas sintéticas, respectivamente.

Além do aspecto quantitativo, há que se considerar também que a relação direta entre o PESN de solos decorrente e os teores de óxidos deve-se também ao fato de esses constituintes da fase sólida apresentarem grupos $-\mathrm{FeOH}$ e $-\mathrm{AlOH}$ de superfície, passíveis de sofrerem protonação e desprotonação (Sparks, 1995; Zhang \& Zhao, 1997 ) ao passo que a caulinita apresenta, além de grupos aluminol, grupos silanol (-SiOH) em sua superfície que, assim como já mencionado, funcionam apenas como doadores de prótons (Schwertmann \& Fechter, 1982; Sparks, 1995; Zhang \& Zhao, 1997), provavelmente contribuindo para a relação inversa observada no presente trabalho entre os teores desse mineral e o PESN.

\subsubsection{Relações entre o PESN e outros atributos dos solos}

$\mathrm{Na}$ avaliação de relacionamentos individuais entre atributos do solo é interessante, também, que sejam consideradas propriedades de mais fácil e rápida caracterização. Nesse sentido, optou-se por considerar as relações entre os valores do PESN das amostras e seus teores de ferro e alumínio avaliados por meio de dissoluções seletivas na TFSA, uma vez que tais teores apresentam relação direta com a composição mineralógica da fração argila.

O PESN apresentou correlação direta com os teores de ferro $\left(r=0,66^{\star \star}\right)$ e alumínio extraídos com ditionito-citrato $\left(r=0,72^{\star \star}\right)$ bem como com os teores de ferro $\left(r=0,56^{* \star}\right)$ e alumínio $\left(r=0,70^{*}\right)$ extraídos com solução ácida de oxalato de amônio. Embora as referidas correlações encontrem respaldo nas dispersões dos dados apresentadas na Figura 10, pode-se notar claramente nas Figuras 10a, 10b e 10c um

comportamento discrepante do Latossolo Amarelo Ácrico (amostra 5). Ao se desconsiderar essa amostra, os coeficientes de correlação entre o PESN e os teores 
de $\mathrm{Fe}_{\mathrm{DC}}$ e $\mathrm{Al}_{\mathrm{DC}}$ passaram para $0,90^{* *}$ e $0,68^{* *}$, respectivamente, ao passo que os coeficientes entre o referido atributo eletroquímico e os teores de $\mathrm{Fe}_{\text {OXA }}$ e $\mathrm{Al}_{\text {OXA }}$ alcançaram, para ambos os casos, o valor de $0,87^{\star *}$.
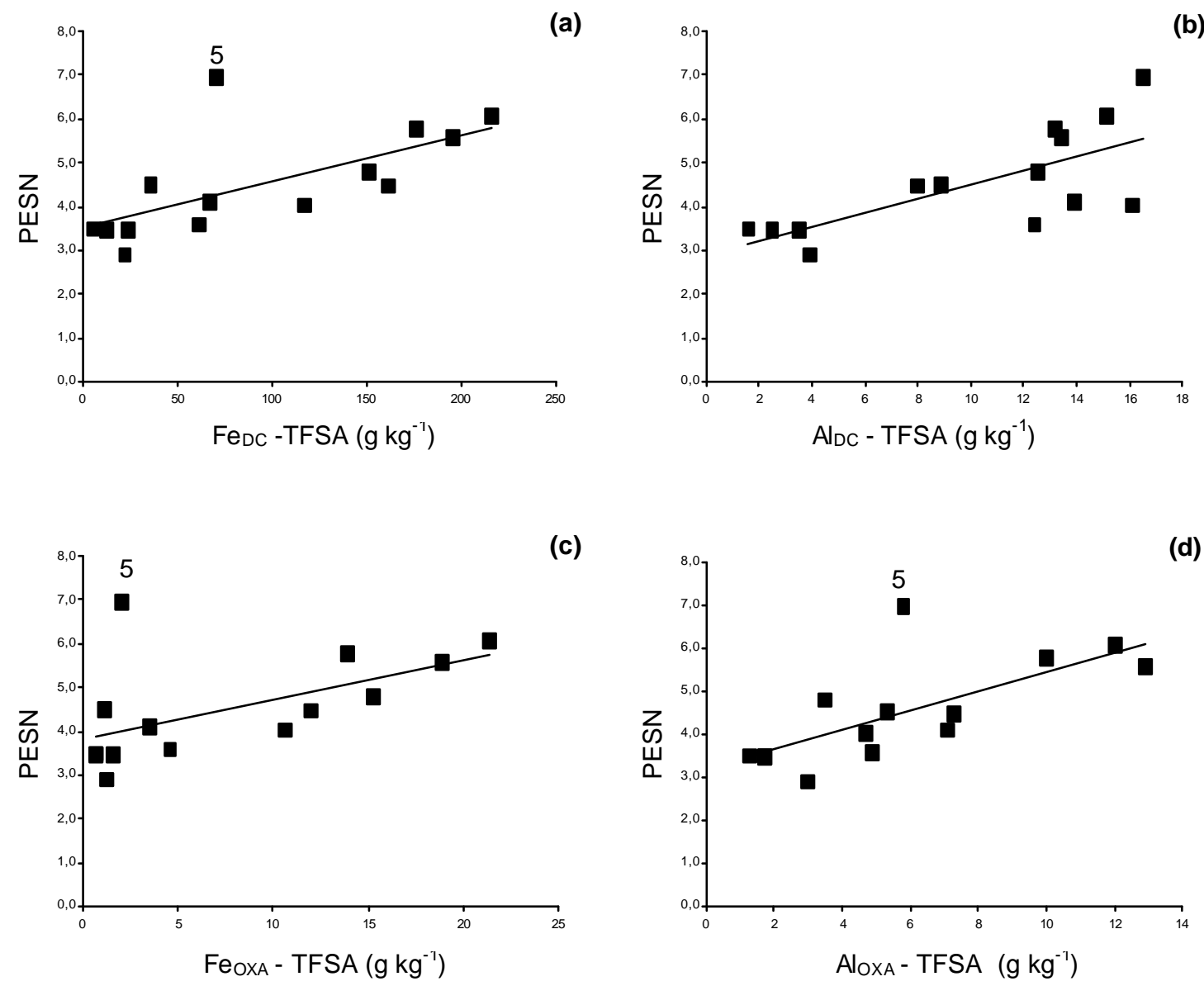

(c)

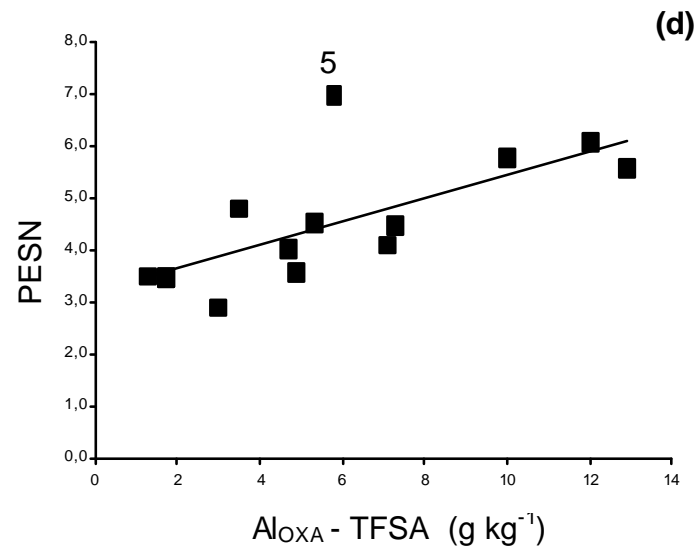

Figura 10 - Relações entre os teores de ferro (a) e alumínio (b) extraídos com ditionitocitrato na TFSA, ferro (c), alumínio (d) extraídos com solução ácida de oxalato de amônio na TFSA, matéria orgânica (e) e cálcio adsorvido (f) e o PESN das amostras avaliadas.

Os teores de matéria orgânica (Tabela 2) não se correlacionaram significativamente com os valores de PESN das amostras avaliadas (Figura11a). Embora haja consenso em relação ao abaixamento do PESN do solo promovido pela 
matéria orgânica (Hendershot \& Lavkulich, 1979; Gillman, 1985; Siqueira et al., 1990), nem sempre esse efeito é detectado (Silva et al., 1996; Dynia \& Camargo, 1998). Provavelmente, a ausência de correlação verificada no presente trabalho seja devida à heterogeneidade das frações orgânicas das amostras. Além disso, há que se considerar também o efeito diferenciado da matéria orgânica sobre o PESN em função da natureza mineralógica do solo, a exemplo do verificado por Siqueira et al. (1990), que constataram um maior abaixamento do PESN pela matéria orgânica em solos mais intemperizados.

De modo similar ao verificado para a matéria orgânica, não se constatou correlação significativa entre o teor de cálcio no complexo sortivo e o PESN das amostras avaliadas, quer consideradas em sua quase totalidade $(n=14)$ (Figura 11b) ou utilizando-se apenas os Latossolos nas correlações. Uma possível correlação direta entre essas variáveis é baseada na possibilidade de ocorrência de adsorção específica de cálcio e conseqüente aumento da densidade superficial de cargas positivas, o que resultaria em aumento no PESN (Kinniburgh et al., 1975; Charlet \& Sposito, 1989).

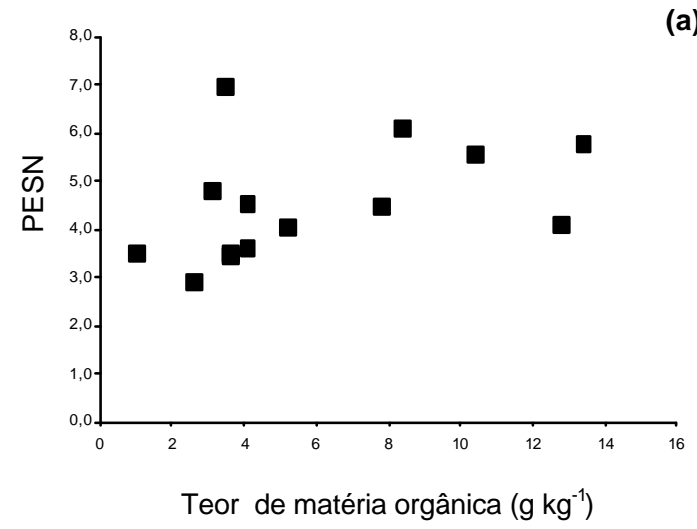

(a)

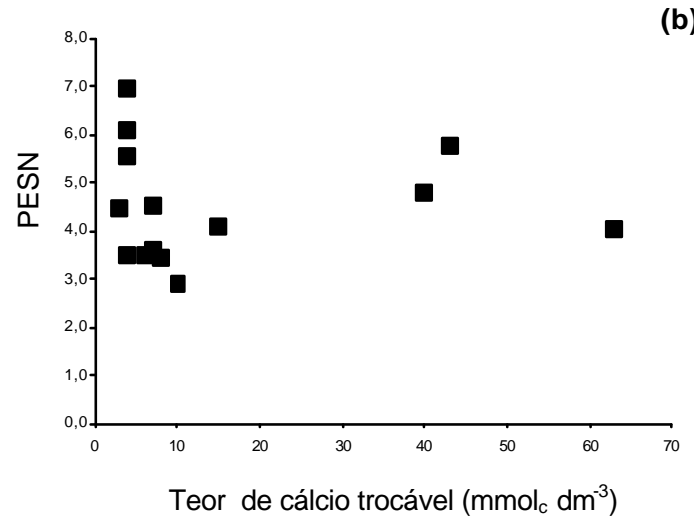

Figura 11 - Relações entre o PESN e os teores de matéria orgânica (a) e cálcio trocável $(b)(n=14)$. 


\subsubsection{Cargas elétricas}

\subsubsection{Métodos de determinação da CTC e estimativa da carga líquida}

A capacidade de troca catiônica efetiva das amostras estudadas foi determinada utilizando-se três métodos distintos que corresponderam à soma dos teores de bases e alumínio trocáveis $\left(\mathrm{CTC}_{1}\right)$, ao da adsorção de bário $\left(\mathrm{CTC}_{2}\right)$ e ao método da adsorção de césio $\left(\mathrm{CTC}_{3}\right)$. Em geral, os valores obtidos pelos diferentes métodos foram similares (Tabela 8).

Tabela 8. Valores de CTC, CTA, carga elétrica líquida e $\Delta \mathrm{pH}$ das amostras avaliadas.

\begin{tabular}{|c|c|c|c|c|c|c|c|}
\hline \multirow{2}{*}{ Núm. } & \multirow{2}{*}{ Classe } & CTC $_{1}$ & $\mathrm{CTC}_{2}$ & $\mathrm{CTC}_{3}$ & CTA & Carga líquida & \multirow{2}{*}{$\Delta \mathrm{pH}$} \\
\hline & & $\mathrm{mmol}_{\mathrm{c}} \mathrm{dm}^{3}{ }^{3}$ & \multicolumn{4}{|c|}{$\mathrm{mmol}_{\mathrm{c}} \mathrm{kg}^{-1}$} & \\
\hline 1 & LVwf & 5,5 & 28,7 & 24,8 & 5,7 & $-23,0$ & $+0,11$ \\
\hline 2 & LVef & 47,2 & 59,5 & 50,2 & 1,0 & $-58,5$ & $-0,77$ \\
\hline 3 & LVdf & 5,0 & 23,2 & 20,5 & 4,3 & $-18,9$ & $-0,08$ \\
\hline 4 & LVwf & 6,1 & 29,4 & 18,9 & 7,9 & $-21,5$ & $+0,36$ \\
\hline 5 & LAw & 7,1 & 30,0 & 12,8 & 8,1 & $-21,9$ & $+0,87$ \\
\hline 6 & LVd & 23,6 & 44,8 & 46,1 & 3,7 & $-41,1$ & $-0,83$ \\
\hline 7 & LVAd & 11,5 & 18,0 & 14,1 & 1,2 & $-16,8$ & $-0,94$ \\
\hline 8 & LVAd & 10,1 & 17,7 & 12,0 & 2,4 & $-15,3$ & $-0,42$ \\
\hline 9 & NVef & 43,3 & 55,1 & 53,5 & 3,6 & $-51,5$ & $-0,63$ \\
\hline 10 & PVAd & 32,4 & 36,6 & 36,6 & 0,9 & $-35,7$ & $-1,12$ \\
\hline 11 & PVAd & 13,5 & 15,6 & 11,4 & 0,4 & $-15,2$ & $-0,76$ \\
\hline 12 & PVd & 80,5 & 94,5 & 88,7 & 3,6 & $-90,9$ & $-0,81$ \\
\hline 13 & $P V d$ & 37,3 & 51,3 & 60,5 & 6,0 & $-45,3$ & $-1,12$ \\
\hline 14 & PVAe & 117,9 & 98,3 & 143,7 & 0,5 & $-97,8$ & $-1,32$ \\
\hline 15 & RQo & 8,2 & 9,8 & 3,0 & 0,2 & $-9,6$ & $-0,47$ \\
\hline
\end{tabular}


Os valores de CTC determinados pelos diferentes métodos apresentaram elevada correlação entre si: $r=0,94^{* *}\left(\mathrm{CTC}_{1}\right.$ e $\left.\mathrm{CTC}_{2}\right), r=0,97^{* *}\left(\mathrm{CTC}_{1}\right.$ e $\left.\mathrm{CTC}_{3}\right)$ e $r=0,95^{\star *}\left(\mathrm{CTC}_{2}\right.$ e $\left.\mathrm{CTC}_{3}\right)$. Contudo, embora os coeficientes de correlação tenham apresentado pequenas diferenças, a visualização das dispersões dos dados (Figura 12) permite verificar que a comparação entre os valores de CTC obtidos pelos métodos que empregaram cátions índices $\left(\mathrm{CTC}_{2}\right.$ e $\left.\mathrm{CTC}_{3}\right)$ demonstra uma concentração de dados mais próxima da linha de igualdade (Figura 9c), sendo o maior afastamento apresentado pelo ponto referente ao Argissolo Vermelho-Amarelo eutrófico (amostra 14).

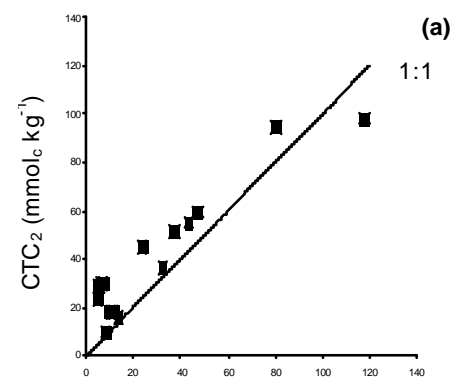

$\mathrm{CTC}_{1}\left(\mathrm{mmol}_{\mathrm{c}} \mathrm{dm}^{-3}\right)$

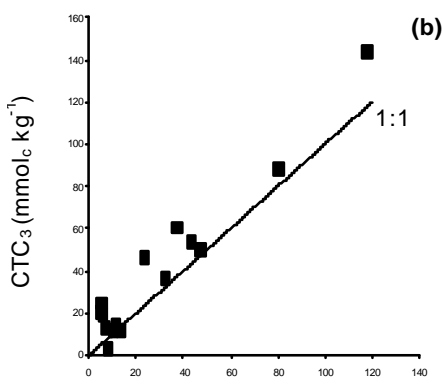

$\mathrm{CTC}_{1}\left(\mathrm{mmol}_{\mathrm{c}} \mathrm{dm}^{-3}\right)$

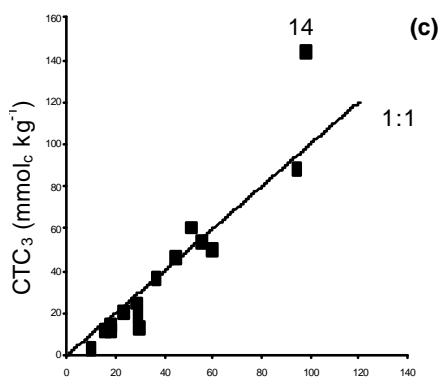

$\mathrm{CTC}_{2}\left(\mathrm{mmol}_{\mathrm{c} \mathrm{kg}}{ }^{-1}\right)$

Figura 12 - Relações entre os valores de CTC determinados por diferentes métodos. $\mathrm{CTC}_{1}=$ método da soma de bases $+\mathrm{Al}$ trocável, $\mathrm{CTC}_{2}=$ adsorção de bário, $\mathrm{CTC}_{3}=$ adsorção de césio.

As amostras estudadas, com exceção das coletadas nos Latossolos Vermelhos Acriférricos e no Latossolo Amarelo Ácrico, apresentaram valores de $\Delta \mathrm{pH}$ menores que zero (Tabela 8), o que indica a existência de carga elétrica superficial líquida negativa no complexo sortivo das mesmas. Considerando-se o método de Gillman (1979), com o qual foram determinados os valores da $\mathrm{CTC}_{2}$ e da CTA, verifica-se que para essas amostras a diferença CTA - CTC 2 resultou em valores negativos, o que concorda com a inferência realizada a partir do índice $\Delta \mathrm{pH}$. Por outro lado, para os solos com caráter ácrico, os valores de $\mathrm{CTA}$ e $\mathrm{CTC}_{2}$ não apresentaram uma diferença em sinal compatível tanto com os valores positivos de $\Delta \mathrm{pH}$ quanto com o fato de seus valores 
de $\mathrm{pH} \mathrm{H}_{2} \mathrm{O}$ e pH KCl serem menores que os dos respectivos valores de PESN. Apesar das diferenças metodológicas, pode-se observar uma tendência coerente entre o sinal esperado para a carga líquida e os valores de $\Delta \mathrm{pH}$ apenas quando se comparam os valores de $\mathrm{CTC}_{1}$ e CTA dessas amostras (Tabela 8).

A determinação da CTC, pelo método da soma $\left(\mathrm{CTC}_{1}\right)$, foi efetuada no presente trabalho utilizando-se teores de bases trocáveis obtidos por extração com resina de troca iônica, que se processa em meio aquoso, sem o emprego de soluções salinas (Raij \& Quaggio, 2001). Desse modo a força iônica da solução durante a extração é muito baixa e apenas os íons passíveis de serem extraídos pela resina são contabilizados na CTC, fato que se aplica muito bem aos solos com caráter ácrico, uma vez que a quase totalidade da CTC efetiva dos mesmos corresponde àsoma de bases trocáveis, haja vista os teores baixos e muitas vezes inexistentes de Al trocável característicos desses solos (Alleoni \& Camargo, 1995).

A hipótese de erro analítico durante a execução do método de Gillman (1979) torna-se pouco provável considerando-se o fato de que dentre os métodos utilizados para a determinação da CTC, os que empregaram a saturação do complexo sortivo com cátions índice $\left(\mathrm{CTC}_{2}\right.$ e $\left.\mathrm{CTC}_{3}\right)$ foram os que apresentaram resultados mais similares (Figura 9c). Além disso, ao considerar-se os três métodos empregados, verifica-se que, além dos valores de $\mathrm{CTC}_{1}$ das amostras com caráter ácrico terem se apresentado entre os mais discrepantes em relação aos valores da $\mathrm{CTC}_{2}$ e da $\mathrm{CTC}_{3}$, eles foram os únicos que, apesar das diferenças metodológicas, apresentaram-se coerentes com as magnitudes esperadas em relação àCTA.

Considerando-se que a existência de carga líquida negativa foi também observada por Ranst et al. (1998) em amostras subsuperficiais de solos africanos que apresentavam valores positivos de $\Delta \mathrm{pH}$, as observações do presente trabalho sugerem a necessidade de revisão e aprimoramento dos métodos de determinação de CTC e CTA efetivas de solos com caráter ácrico, de modo a possibilitar a obtenção de estimativas mais coerentes e realísticas desses atributos para esses solos.

Nesse sentido, a avaliação da força iônica das soluções de solos ácricos, efetuada em amostras provenientes de camadas superficiais e subsuperficiais de áreas submetidas a diferentes manejos, poderia ser o ponto de partida para um possível desenvolvimento metodológico alternativo para a avaliação das cargas superficiais 
desses solos. Tal procedimento poderia também ser útil para a verificação da aplicabilidade geral do valor $0,006 \mathrm{~mol} \mathrm{~L}^{-1}$ para força iônica da solução de saturação como sugerido por Gillman (1979) para a determinação da CTC efetiva de solos intemperizados, uma vez que o referido valor foi estabelecido a partir de dados obtidos para apenas seis perfis de solos australianos (Gillman \& Bell, 1978).

\subsubsection{Capacidade de troca aniônica}

A capacidade de troca aniônica das amostras estudadas variou de 0,19 a 8,12 $\mathrm{mmol}_{\mathrm{c}} \mathrm{kg}^{-1}$ (Tabela 8). Desconsiderando-se a amostra 14, verificou-se que os maiores valores de CTA foram observados nos solos menos cauliníticos $\left(r=-0,72^{\star *}\right)$ e que os mesmos estiveram diretamente associados aos teores de gibbsita $\left(r=0,54^{*}\right)$ e $\mathrm{Al}(\mathrm{OH})_{3}$ mal cristalizado $\left(r=0,71^{* *}\right)$ na fração argila. As correlações entre a CTA e os teores dos demais constituintes mineralógicos semiquantificados na fração argila foram não significativas, fato corroborado pela elevada dispersão dos pontos experimentais (Figura 13).

As considerações apresentadas para as relações entre o PESN e a composição mineralógica das amostras estudadas podem também ser estendidas æ̀s relações observadas no presente trabalho entre a magnitude da CTA e os teores de minerais na fração argila, haja vista, que nos solos com cargas variáveis, o desenvolvimento de cargas positivas de superfície dá-se essencialmente pela protonação de grupos -FeOH e -AIOH presentes em constituintes da fase sólida (Raij \& Peech, 1972; Zhang \& Zhao, 1997 ).

A associação negativa observada entre a CTA e os teores de caulinita deve-se possivelmente à maior proporção de grupos -SiOH de superfície observada em solos cauliníticos quando comparada àdos solos oxídicos. Esses grupamentos comportam se nas condições normais de pH apenas como ácidos de Lewis (Sparks, 1995) e portanto não sofrem protonação.

Em relação aos óxidos de ferro cristalinos, a elevada dispersão dos dados (Figuras 13c e 13d) parece também reiterar que as propriedades intrínsecas desses 

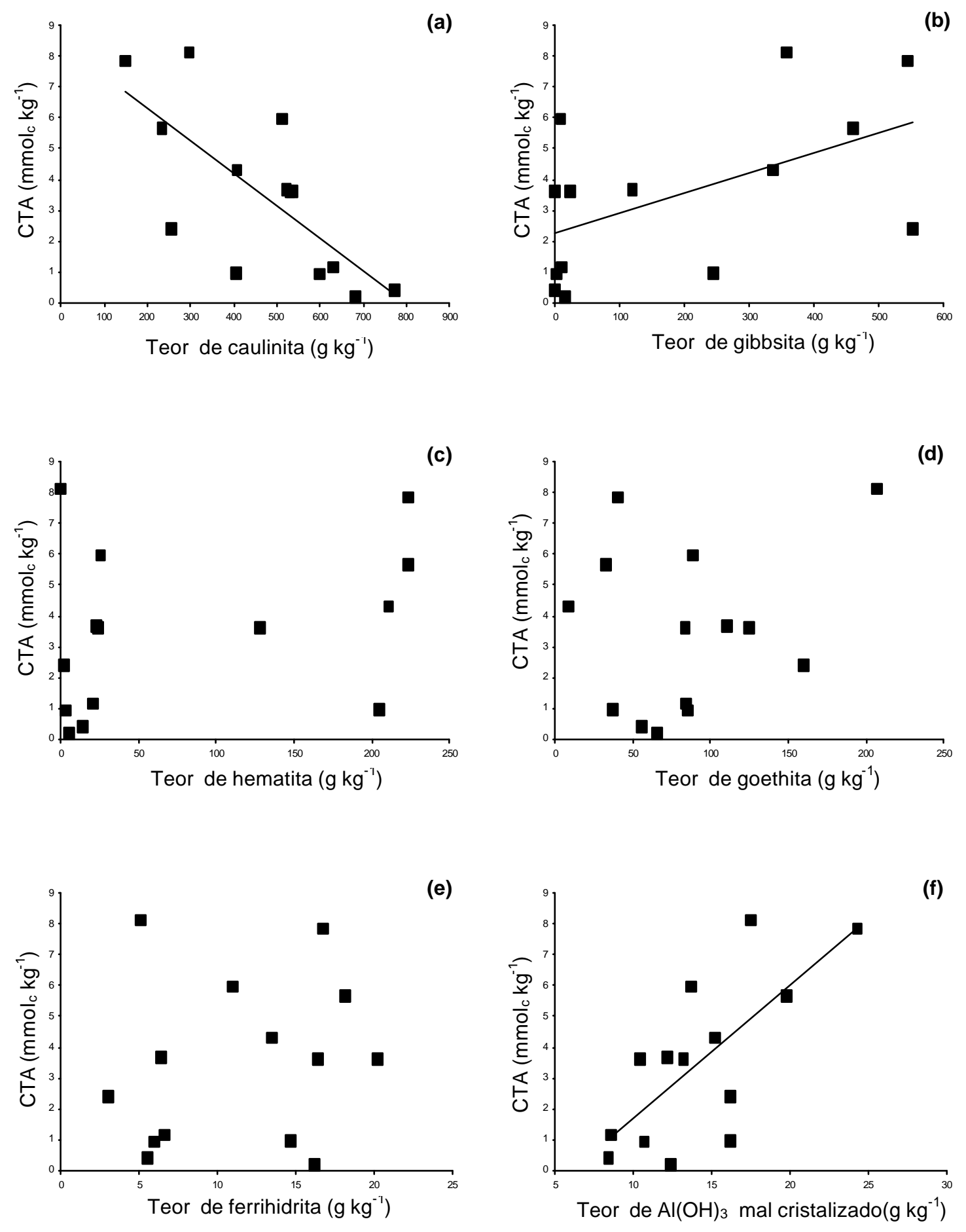

Figura 13 - Relações entre os teores de caulinita (a), gibbsita (b), hematita (c), goethita (d), ferrihidrita (e) e óxido mal cristalizado de alumínio (f) na fração argila e a CTA das amostras avaliadas. 
compostos podem ser mais importantes que as suas quantidades encontradas no solo para a manifestação de suas reconhecidas capacidades de adsorção de ânions ( Ker et al., 1996; Fontes et al., 2001).

É provável que o conjunto de ferrihidritas avaliado apresente heterogeneidade quanto à CTA devido à ocorrência de uma eventual adsorção de silicatos por esses óxidos em magnitudes variáveis, fato que, segundo Schwertmann \& Fechter (1982), contribui para uma diminuição relativa na densidade de grupos $-\mathrm{FeOH}$ de superfície e, portanto, para o desenvolvimento menos expressivo de cargas negativas.

Apesar da elevada dispersão dos dados e do baixo coeficiente de correlação (Figura 13b), o comportamento oposto ao da caulinita, apresentado pela gibbsita, sugere que para esse óxido de alumínio a protonação de grupos $-\mathrm{AlOH}$ parece ser menos dependente de aspectos relacionados à exposição de faces cristalográficas e/ou coordenação de hidroxilas de superfície que o observado para os óxidos de ferro. Contudo, referências sobre a variabilidade comportamental de gibbsitas pedogenéticas são praticamente inexistentes.

De maneira similar ao observado para o PESN, a contrastação dos valores de CTA e dos teores de óxido mal cristalizado de alumínio apresentou uma das melhores dispersões de pontos experimentais (Figura 13f). A expressiva correlação entre as variáveis mencionadas demonstra mais uma vez a importância dos compostos mal cristalizados de Al, que apesar de presentes nos solos sesquioxídicos em pequenas quantidades, bem inferiores às encontradas nos solos alofânicos (Marsh et al. , 1987; Sakurai et al., 1989b), ainda assim exercem acentuada influência em suas capacidades de retenção aniônica (Bolland et al., 1996).

A análise da Figura 14 sugere também, à semelhança do observado para os diferentes óxidos, uma maior relevância para o papel desempenhado pelos óxidos de alumínio na manifestação da CTA das amostras avaliadas, fato que se reflete ms coeficientes obtidos nas análises de correlação levadas a efeito entre os teores de $\mathrm{Al}$ determinados por diferentes métodos na TFSA e os valores de CTA: $r=0,67^{* *}$ para $\mathrm{Al}-\mathrm{H}_{2} \mathrm{SO}_{4}, 0,77^{* *}$ para $\mathrm{Al}_{\mathrm{DC}}$ e $0,59^{*}$ para $\mathrm{Al}_{\text {OXA }}$. Esses coeficientes foram, em geral, maiores que os obtidos para as correlações estabelecidas entre os teores de ferro na TFSA obtidos por diferentes métodos de dissolução e o referido atributo eletroquímico: $r=0,57^{*}$ para $\mathrm{Fe}-\mathrm{H}_{2} \mathrm{SO}_{4}, 0,54^{*}$ para $\mathrm{Fe}_{\mathrm{DC}}$ e $0,47^{\text {ns }}$ para $\mathrm{Fe}_{\mathrm{OXA}}$. 

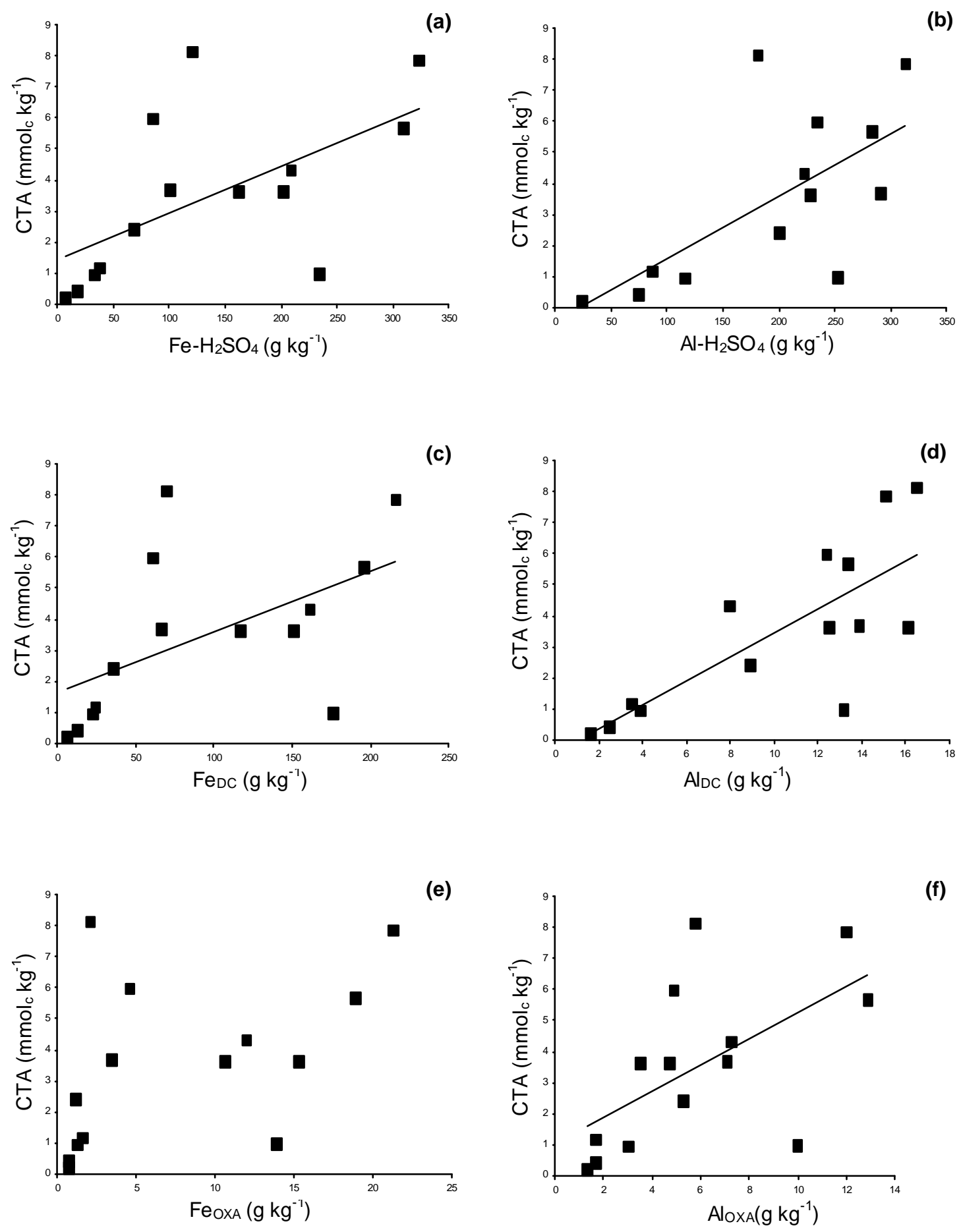

(f)

Figura 14 - Relações entre a CTA e os teores de $\mathrm{Fe} \mathrm{(a)} \mathrm{e} \mathrm{Al} \mathrm{(b)} \mathrm{obtidos} \mathrm{por} \mathrm{ataque}$ sulfúrico, $\mathrm{Fe}$ (c) e $\mathrm{Al}$ (d) obtidos por dissolução com ditionito-citrato de sódio e $\mathrm{Fe}$ (e) e Al (f) obtidos por dissolução com oxalato ácido de amônio na TFSA . 


\subsubsection{Cargas elétricas negativas de caráter permanente e variável}

O método da adsorção de césio foi proposto por Anderson \& Sposito (1991) para a avaliação da carga elétrica negativa de caráter permanente e se fundamenta na elevada afinidade que o íon $\mathrm{Cs}^{+}$apresenta pelos sítios de troca permanentes presentes em argilominerais, que é intensificada pela secagem do adsorvente após sua saturação com o referido íon. Em seqüência à secagem, promove -se uma reação de troca com o íon $\mathrm{Li}^{+}$, que remove os íons $\mathrm{Cs}^{+}$adsorvidos à cargas de caráter variável e, em seguida, utilizando-se o íon $\mathrm{NH}_{4}{ }^{+}$como trocador, efetua-se a extração dos íons $\mathrm{Cs}^{+}$ retidos nos sítios de troca constituídos por cargas permanentes.

No presente trabalho, as cargas negativas permanentes presentes nas amostras avaliadas variaram de $1,2 \mathrm{mmol}_{\mathrm{c}} \mathrm{kg}^{-1}$ no Neossolo Quartzarênico Órtico a 103,9 mmolc $\mathrm{kg}^{-1}$ no Argissolo Vermelho-Amarelo Eutrófico. As cargas variáveis apresentaram valores entre 1,8 e 39,8 $\mathrm{mmolc} \mathrm{kg}^{-1}$ (Tabela 9).

Tabela 9. Quantidades de cargas negativas de caráter permanente e variável presentes nas amostras avaliadas.

\begin{tabular}{|c|c|c|c|c|c|}
\hline \multirow{3}{*}{ Número } & \multirow{3}{*}{ Classe } & \multicolumn{4}{|c|}{ Cargas negativas } \\
\hline & & permanentes & variáveis & permanentes & variáveis \\
\hline & & \multicolumn{2}{|c|}{$\mathrm{mmolkg}^{-1} \longrightarrow$} & \multicolumn{2}{|c|}{$\%$} \\
\hline 1 & LVwf & 7,4 & 17,4 & 29,8 & 70,2 \\
\hline 2 & LVef & 20,7 & 29,5 & 41,2 & 58,8 \\
\hline 3 & LVdf & 7,3 & 13,2 & 35,5 & 64,5 \\
\hline 4 & LVwf & 5,7 & 13,2 & 30,0 & 70,0 \\
\hline 5 & LAw & 4,3 & 8,5 & 33,6 & 66,4 \\
\hline 6 & LVd & 22,0 & 24,1 & 47,7 & 52,3 \\
\hline 7 & LVAd & 5,6 & 8,5 & 39,7 & 60,3 \\
\hline 8 & LVAd & 3,9 & 8,1 & 32,5 & 67,5 \\
\hline 9 & NVef & 29,0 & 24,5 & 54,2 & 45,8 \\
\hline 10 & PVAd & 18,2 & 18,4 & 49,7 & 50,3 \\
\hline 11 & PVAd & 3,8 & 7,6 & 33,3 & 66,7 \\
\hline 12 & PVe & 51,9 & 36,8 & 58,5 & 41,5 \\
\hline 13 & PVd & 34,3 & 26,2 & 56,7 & 43,3 \\
\hline 14 & PVAe & 103,9 & 39,8 & 72,3 & 27,7 \\
\hline 15 & RQo & 1,2 & 1,8 & 40,0 & 60,0 \\
\hline
\end{tabular}


As cargas negativas de caráter permanente corresponderam, em média, a 38\% da carga negativa total, excetuando-se dessa estimativa as amostras 9, 12, 13 e 14, nas quais se observou predomínio de cargas permanentes (Tabela 9). Esse resultado é, em parte, compatível com o obtido por Chorover \& Sposito (1995) para amostras superficiais de quatro solos cauliníticos brasileiros. Esses autores verificaram que naquelas amostras as cargas negativas permanentes corresponderam, em termos médios, a $31 \%$ da carga negativa total.

Para os Latossolos, observou-se que a cargas negativas permanentes corresponderam, em média, a $36 \%$ da carga negativa total, com o maior valor sendo observado no Latossolo Vermelho-Amarelo Distrófico (amostra 6). Esse fato apresenta relação direta com a composição mineralógica desse solo, pois foi o único Latossolo que apresentou, além de vermiculita com hidróxi nas entrecamadas (Figura 2a), ilita como constituinte de sua fração argila (Figura 5a). Por outro lado, mesmo nos Latossolos cujos difratogramas de raios $X$ não evidenciaram a presença de argilominerais do tipo 2:1 (amostras 1, 3, 4 e 8) e, no Neossolo, solo em que também não se detectou a presença de argilominerais do tipo 2:1, foi possível a determinação de cargas negativas permanentes, fato também verificado por Fontes \& Sposito (1995).

No caso das amostras 12, 13 e 14 a predominância de cargas negativas permanentes apresenta relação direta com a composição mineralógica das frações argila das mesmas, que apresentam ilita e vermiculita com hidróxi nas entrecamadas, como verificado nos difratogramas de raios $X$ (Figuras 3b, 3c, 3d, 6b,6c e 6d). Por outro lado, a predominância de cargas permanentes observada para o Nitossolo Vermelho Eutroférrico não é corroborada pelas informações dos difratogramas (Figuras 2d e $5 d$ ).

A avaliação da efetividade do método da adsorção de césio para a quantificação de cargas permanentes foi realizada por meio de análises de correlação linear simples entre os valores obtidos para essas cargas e os teores complementares à soma dos teores de todos os componentes mineralógi cos semiquantificados na fração argila das amostras avaliadas (Tabela 5). Essas análises foram efetuadas partindo-se da premissa de que nesses teores complementares estão contemplados os minerais responsáveis, em maior proporção, pelas cargas negativas permanentes determinadas nas amostras. 
Ao se considerar as 15 amostras estudadas, os coeficientes de correlação obtidos entre o teor da fração complementar e a carga negativa total $\left(\mathrm{CTC}_{3}\right.$ na Tabela 8), a carga negativa permanente $\left(\mathrm{CTC}_{\mathrm{p}}\right)$ e a carga negativa variável $\left(\mathrm{CTC}_{\mathrm{v}}\right)$ foram respectivamente iguais a $0,79^{\star *}, 0,84^{* *}$ e $0,60^{*}$. Retirando-se das análises a amostra 14, que é possuidora da maior carga permanente e apresenta o maior teor complementar, os referidos coeficientes passaram a $0,53^{*}, 0,62^{*}$ e $0,34^{\text {ns }}$. A manutenção da significância da correlação para as cargas permanentes e a perda da mesma para as cargas variáveis, após a exclusão da amostra 14, provavelmente se deva à elevada afinidade que o césio apresenta pela vermiculita (Maes et al., 1999) e pela ilita (Hird et al.,1996). Desse modo, pode-se concluir que o método utilizado no presente trabalho para a quantificação diferenciada de cargas permanentes e variáveis apresentou, em geral, resultados coerentes com a composição mineralógica das amostras avaliadas.

Embora se considere que o método da adsorção de césio possa ser utilizado para a detecção de argilominerais do tipo 2:1 presentes em pequenas quantidades, 0 suficiente para não permitir a identificação dos mesmos em difratogramas de raios $\mathrm{X}$ (Fontes \& Sposito, 1995), seria interessante a realização de estudos mais conclusivos que possibilitassem um melhor conhecimento de possíveis limitações desse método. Uma opção nesse sentido, seria a contrastação de valores de carga permanente determinados com o uso do presente método e estimados com a aplicação da teoria da dupla camada elétrica a sistemas (solo ou fração argila) contendo cargas permanentes e variáveis (Singh \& Uehara, 1999) e intensamente caracterizados quanto aos seus atributos mineralógicos.

\subsection{3 pH em solução de $\mathrm{NaF} 1 \mathrm{~mol} \mathrm{~L}^{-1}(\mathrm{pH} \mathrm{NaF})$}

A determinação do $\mathrm{pH} \mathrm{NaF}$ permite avaliar a quantidade de hidroxilas passíveis de serem liberadas por uma amostra de solo após sua agitação com solução de $\mathrm{NaF} 1 \mathrm{~mol} \mathrm{~L}^{-1}$. Inicialmente, o uso pedológico do $\mathrm{pH}$ NaF esteve voltado para a avaliação da presença de alofana em solos de origem vulcânica (Fieldes \& Perrott, 1966). Posteriormente, esse atributo passou a ser utilizado como indicador da capacidade de adsorção de fosfato de solos alofânicos (Alvarado \& Buol, 1985) tendo, 
por fim, sua potencialidade de utilização para a avaliação da referida adsorção em solos sesquioxídicos demonstrada anos mais tarde nos trabalhos de Singh \& Gilkes (1991), Gilkes \& Hughes (1994) e Bolland et al. 1996.

Os valores obtidos para o pH NaF (Tabela 10) variaram de 8,84 a 10,70 na TFSA, de 9,01 a 11,36 na fração argila e de 10,22 a 11,88 na fração argila isenta de óxidos de ferro. Visando-se a comparar os valores medidos nas diferentes frações, realizou-se a aplicação do teste $F$ à análise de variância dos resultados, seguida da aplicação do teste de comparações múltiplas de Tukey.

Tabela 10. Valores de pH NaF determinados na TFSA, fração argila e fração argila desferrificada das amostras estudadas.

\begin{tabular}{|c|c|c|c|c|c|c|c|}
\hline \multirow{3}{*}{$\begin{array}{r}\text { Núm. } \\
1\end{array}$} & \multirow{3}{*}{$\begin{array}{c}\text { Classe } \\
\text { LVwf }\end{array}$} & \multicolumn{6}{|c|}{$\mathrm{pH} \mathrm{NaF}$} \\
\hline & & \multicolumn{2}{|l|}{ TFSA } & \multicolumn{2}{|l|}{ Argila } & \multicolumn{2}{|c|}{ Argila desferrificada } \\
\hline & & 10,40 & c & 11,04 & $\mathrm{~b}$ & 11,74 & $\mathrm{a}$ \\
\hline 2 & LVef & 10,25 & c & 10,60 & $b$ & 11,20 & $\mathrm{a}$ \\
\hline 3 & LVdf & 10,28 & c & 10,78 & $b$ & 11,45 & $\mathrm{a}$ \\
\hline 4 & LVwf & 10,70 & c & 11,36 & $\mathrm{~b}$ & 11,88 & $\mathrm{a}$ \\
\hline 5 & LAw & 10,37 & c & 11,08 & $b$ & 11,63 & $\mathrm{a}$ \\
\hline 6 & LVd & 10,31 & $\mathrm{~b}$ & 10,43 & $b$ & 10,86 & $\mathrm{a}$ \\
\hline 7 & LVAd & 9,27 & c & 9,67 & $\mathrm{~b}$ & 10,67 & a \\
\hline 8 & LVAd & 10,27 & c & 10,91 & $b$ & 11,67 & $\mathrm{a}$ \\
\hline 9 & NVef & 9,82 & b & 9,60 & c & 10,87 & $\mathrm{a}$ \\
\hline 10 & PVAd & 9,53 & $\mathrm{~b}$ & 9,35 & c & 10,53 & a \\
\hline 11 & PVAd & 8,84 & c & 9,18 & $\mathrm{~b}$ & 10,54 & $\mathrm{a}$ \\
\hline 12 & $P V d$ & 9,68 & b & 9,16 & c & 10,53 & a \\
\hline 13 & PVd & 9,98 & $b$ & 10,01 & $\mathrm{~b}$ & 10,70 & a \\
\hline 14 & PVAe & 9,96 & $b$ & 9,28 & c & 10,22 & $\mathrm{a}$ \\
\hline 15 & RQo & 8,97 & b & 9,01 & b & 10,55 & $a$ \\
\hline
\end{tabular}

Médias seguidas por uma mesma letra não diferem entre si a $1 \%$ de probabilidade pelo teste de Tukey.

Comparações feitas na linha. DMS $=0,14$ unidades de $\mathrm{pH}$. C.V. $=0,45 \%$ 
Os resultados da análise de variância mostraram que o comportamento do $\mathrm{pH} \mathrm{NaF}$ na fração considerada (TFSA, argila total e argila isenta de óxidos de ferro) foi variável em função da classe de solo, fato que se deve à interação significativa verificada entre os referidos fatores $(F=76,6 ; p>F=0,0001)$. A observação dos resultados apresentados na Tabela 9 permite verificar que os valores de $\mathrm{pH}$ NAF foram maiores na fração argila isenta de óxidos de ferro em todas as amostras. Excetuandose as amostras 9,10,12,13, 14 e 15, pôde-se verificar também que os valores de pH $\mathrm{NaF}$ foram maiores na fração argila que na TFSA

A fração argila das amostras estudadas exerceu acentuada influência sobre os valores de $\mathrm{pH}$ NaF medidos na TFSA, fato constatado pela acentuada associação observada entre os valores de $\mathrm{pH} \mathrm{NaF}$ medidos da TFSA e na referida fração $\left(r=0,91^{\star \star}\right)$. É provável, que o menor coeficiente de correlação observado ao se contrastar os valores de pH NaF medidos na TFSA e na fração argila isenta de óxidos de ferro $\left(r=0,83^{* *}\right)$ se deva àremoção, nessa última, de compostos mal cristalizados de alumínio efetuada pelo tratamento com a solução de ditionito-citrato de sódio (Perrott et al., 1976a).

Os valores de $\mathrm{pH} \mathrm{NaF}$, medidos na fração argila isenta de óxidos de ferro, apresentaram associação direta com os teores de gibbsita dessa fração $\left(r=0,98^{* *}\right)$ ao passo que, os teores de caulinita, apresentaram-se negativamente associados com o $\mathrm{pH} \mathrm{NaF}\left(r=-0,92^{\star *}\right)$ (Figura 15).

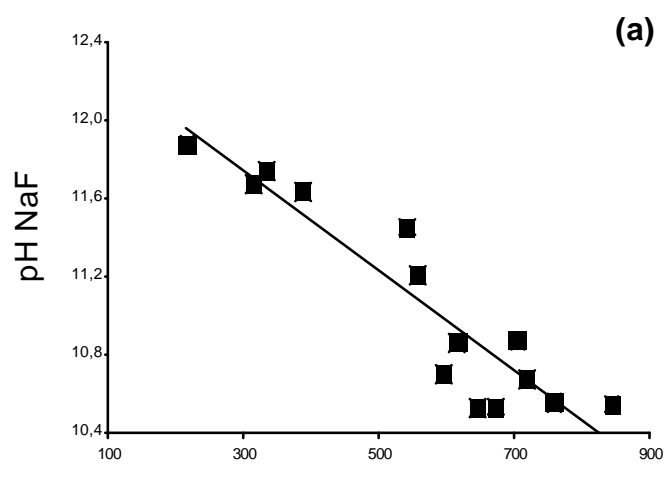

Teor de caulinita $\left(\mathrm{g} \mathrm{kg}^{-1}\right)$

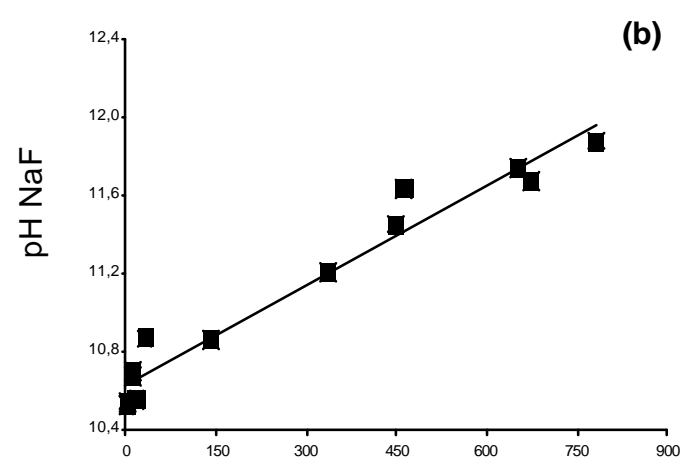

Teor de gibbsita $\left(\mathrm{g} \mathrm{kg}^{-1}\right)$

Figura 15 - Relação entre os teores de caulinita (a) e gibbsita (b) na fração argila desferrificada e os valores de $\mathrm{pH} \mathrm{NaF}$ determinados nessa fração $(n=14)$. 
Tal fato destaca a importância dos referidos minerais na definição dos valores de $\mathrm{pH} \mathrm{NaF}$ dos solos avaliados e apresenta concordância com as tendências observadas por Perrott et al. (1976a) quanto à capacidades de liberação de hidroxilas para a solução de $\mathrm{NaF}$ apresentadas por esses minerais.

Os elevados valores de $\mathrm{pH}$, normalmente determinados nas suspensões de solo-solução de $\mathrm{NaF}$, podem ser devidos à liberação para a solução de grupos $\mathrm{OH}^{-}$de superfície passíveis de serem trocados pelos íons F (Bower \& Hatcher, 1967). Por outro lado, há também a possibilidade de que os íons $\mathrm{F}$ possam promover alterações na estrutura de minerais, resultando no aumento de pH da solução e na formação de complexos fluoralumínicos solúveis como o $\mathrm{AlF}_{6}{ }^{3-}$ (Huang \& Jackson, 1965). Dessa forma, visando-se a avaliar as causas das estreitas correlações observadas entre o $\mathrm{pH}$ $\mathrm{NaF}$ e os teores de gibbsita e caulinita na fração argila desferrificada, procedeu-se à caracterização mineralógica por DRX dos materiais desferrificados das amostras $4 \mathrm{e}$ 11, que apresentam elevados e contrastantes teores dos referidos minerais, após o tratamento dos mesmos com solução de $\mathrm{NaF} 1 \mathrm{~mol} \mathrm{~L}^{-1}$ nas mesmas condições empregadas para a avaliação do $\mathrm{pH}$.

A análise dos difratogramas obtidos (Figura 16) permite verificar que a solução de $\mathrm{NaF}$ não promoveu marcantes alterações estruturais na gibbsita e na caulinita das amostras avaliadas, haja vista a similaridade das intensidades dos picos de difração desses minerais antes e após o tratamento com $\mathrm{NaF}$. Desse modo, ao menos para esses minerais, a hipótese mais provável é a de que a influência dos mesmos sobre os elevados valores de $\mathrm{pH}$ verificados após o tratamento das amostras com a solução de $\mathrm{NaF}$ consista na liberação de hidroxilas de superfície.

Os relacionamentos entre os valores de $\mathrm{pH} \mathrm{NaF}$ determinados na TFSA e na fração argila das amostras e alguns de seus atributos foram avaliados por meio de análises de correlação linear simples, as quais foram realizadas desconsiderando-se a amostra 14.

A observação dos coeficientes de correlação apresentados na Tabela 11 permite verificar que as diferentes formas de alumínio consideradas apresentaram relação direta com o pH NaF determinado na TFSA e na fração argila das amostras expressivas. Relações semelhantes à verificadas no presente trabalho foram obtidas por Gilkes \& Hughes (1994) e Bolland et al. (1996) em solos australianos. 


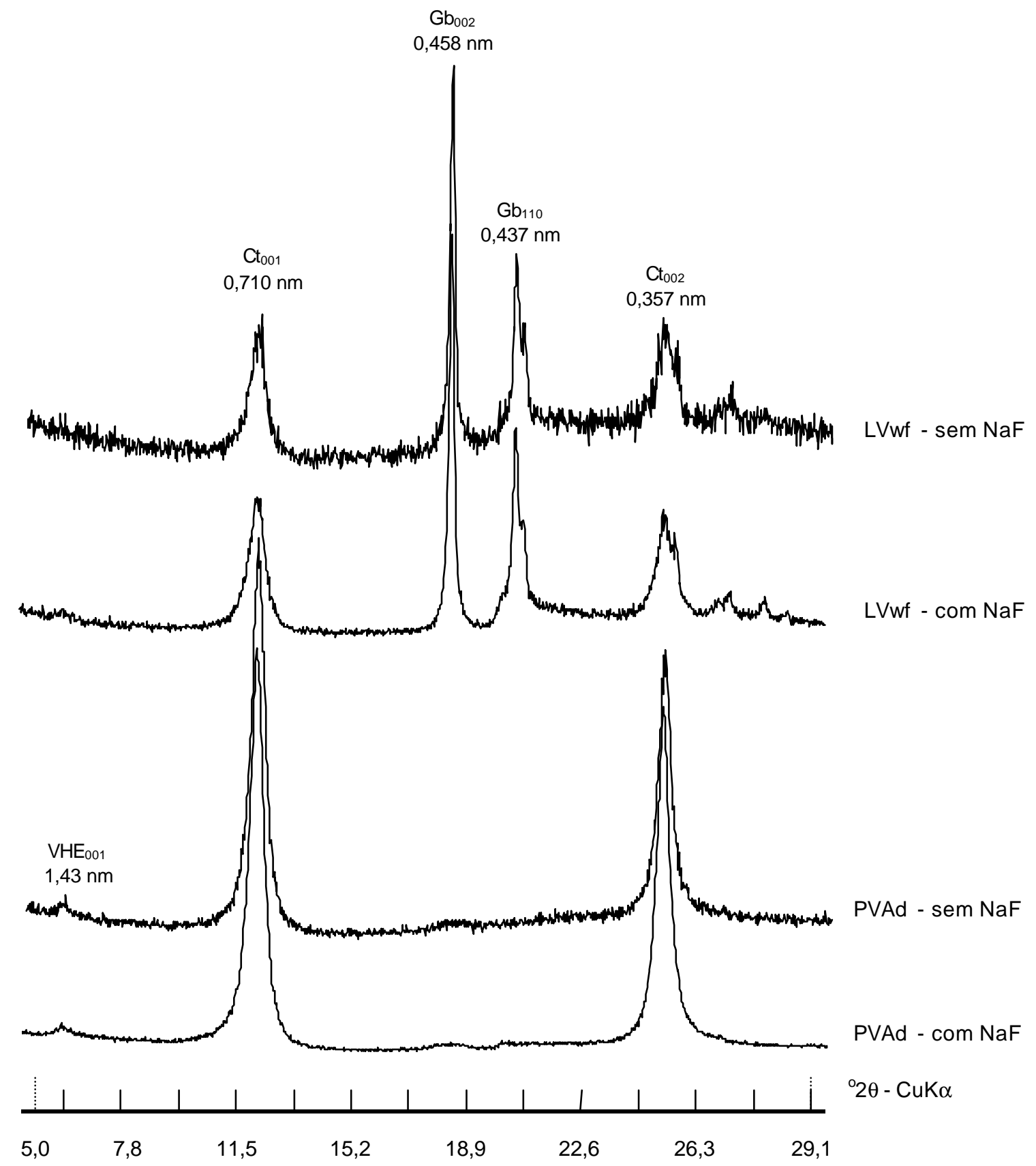

Figura 16 - Difratogramas de raios $X$ da fração argila desferrificada do Latossolo Vermelho Acriférrico (LVwf) (amostra 4) e do Argissolo Vermelho-Amarelo Distrófico (PVAd) (amostra 11) antes e após o tratamento com solução de $\mathrm{NaF} 1 \mathrm{~mol} \mathrm{~L}^{-1}$. VHE = vermiculita com hidróxi nas entrecamadas, $\mathrm{Ct}=$ caulinita, $\mathrm{Gb}=$ gibbsita. 
Tabela 11. Coeficientes de correlação linear simples $(r)$ entre valores de $\mathrm{pH} \mathrm{NaF}$ determinados em diferentes frações e atributos dos solos estudados $(n=14)$.

\begin{tabular}{|c|c|c|}
\hline \multirow{2}{*}{ Atributo } & \multicolumn{2}{|c|}{$\mathrm{pH} \mathrm{NaF}$} \\
\hline & TFSA & Argila \\
\hline Caulinita & $-0,92^{\star *}$ & $-0,92^{\star \star}$ \\
\hline Gibbsita & $0,78^{* *}$ & $0,91^{* *}$ \\
\hline Goethita & $0,09^{\mathrm{ns}}$ & $0,03^{\text {ns }}$ \\
\hline Ferrihidrita & $0,14^{\mathrm{ns}}$ & $-0,02^{\text {ns }}$ \\
\hline $\mathrm{Al}(\mathrm{OH})_{3}$ mal cristalizado & $0,81^{* *}$ & $0,83^{* *}$ \\
\hline $\mathrm{Fe}-$ ataque sulfúrico & $0,73^{* *}$ & $0,66^{* *}$ \\
\hline$F e_{D C}-T F S A$ & $0,69^{* *}$ & $0,60^{*}$ \\
\hline Fe OXA - TFSA & $0,57^{*}$ & $0,47^{\text {ns }}$ \\
\hline $\mathrm{Al}-$ ataque sulfúrico & $0,88^{* *}$ & $0,69^{\star *}$ \\
\hline$A l_{D C}-T F S A$ & $0,79^{* *}$ & $0,58^{*}$ \\
\hline Aloxa - TFSA & $0,83^{* *}$ & $0,81^{* *}$ \\
\hline $\mathrm{Si}-$ ataque alcalino & $0,28^{\mathrm{ns}}$ & $-0,05^{\mathrm{ns}}$ \\
\hline $\mathrm{Ki}$ & $-0,83^{\star *}$ & $-0,93^{* *}$ \\
\hline $\mathrm{Kr}$ & $-0,85^{\star \star}$ & $-0,90^{\star *}$ \\
\hline $\mathrm{MO}$ & $0,61^{*}$ & $0,57^{*}$ \\
\hline$P$ - rem. & $-0,89^{* *}$ & $-0,68^{*}$ \\
\hline CTA & $0,76^{* *}$ & $0,69^{\star *}$ \\
\hline PESN & $0,73^{* *}$ & $0,79^{* *}$ \\
\hline
\end{tabular}

${ }^{* *} \mathrm{e}$ * significativo a 1 e $5 \%$ de probabilidade pelo teste $\mathrm{t}$, respectivamente.

ns - não significativo 
Estudos realizados por Perrott et al. (1976ab) demonstraram que liberação de hidroxilas para a solução de $\mathrm{NaF}$ depende, dentre outros fatores, da natureza da fase sólida considerada e do $\mathrm{pH}$ dessa solução. Ao avaliar a liberação de hidroxilas por diferentes minerais e óxidos para a solução de $\mathrm{NaF}$ em valor constante de $\mathrm{pH}$, Perrott et al. (1976a) verificaram que os compostos mal cristalizados de Al apresentaram elevada capacidade de liberação de $\mathrm{OH}^{\dagger}$ ao contrário do observado para a caulinita, gibbsita e óxidos de ferro que, por sua vez reagiram em menor extensão com a solução de NaF. Além das capacidades intrínsecas de liberação de hidroxilas apresentadas pelos constituintes da fase sólida, o próprio aumento progressivo do $\mathrm{pH}$ da suspensão, observado após a adição da solução de NaF àamostra de solo, exerce influência diferenciada nessa liberação. Perrott et al. (1976b) verificaram que apenas os óxidos de Al mal cristalizados foram capazes de continuar liberando hidroxilas para a solução de $\mathrm{NaF}$ em valores de $\mathrm{pH}$ maiores que 9,00, ao passo que óxidos mal cristalizados de silício e de ferro apresentaram significativo decréscimo na referida liberação com o aumento do pH.

Com base nessas observações, é provável que acentuada influência negativa verificada no presente trabalho dos teores de caulinita sobre o $\mathrm{pH} \mathrm{NaF}$ seja decorrente da pequena capacidade de liberação de hidroxilas apresentada por esse mineral e de um possível efeito negativo do aumento de $\mathrm{pH}$ sobre essa liberação. Esses fatores e os elevados teores com que esse mineral se apresenta nas amostras estudadas foram possivelmente os responsáveis pela elevada correlação negativa observada entre os valores de $\mathrm{pH} \mathrm{NaF}$ medidos na TFSA e na argila e os teores de caulinita.

Como apresentado na Tabela 10, os valores de pH NaF determinados na fração argila desferrificada mostraram-se maiores que os medidos na fração argila total, mesmo considerando-se a ausência de óxidos de Al mal cristalizados na primeira, que foram removidos pelo tratamento com ditionito-citrato de sódio na etapa de desferrificação. Além da menor capacidade de liberação de hidroxilas apresentada pela gibbsita em relação aos óxidos de Al mal cristalizados, essa capacidade é também muito sensível às variações de $\mathrm{pH}$, diminuindo com 0 aumento deste (Perrott et al., 1976b). Novamente e de modo similar ao proposto para a caulinita, é possível que os elevados teores de gibbsita na fração argila desferrificada tenham sido mais importantes que as propriedades desse mineral na definição dos valores de $\mathrm{pH}$ $\mathrm{NaF}$. 
O teor de matéria orgânica das amostras estudadas correlacionou-se positivamente com o $\mathrm{pH} \mathrm{NaF}$ medido na TFSA $\left(r=0,61^{*}\right)$, desconsiderando-se nesse relacionamento a amostra 14, que apresentou um teor de matéria orgânica muito discrepante em relação ao da maioria dos solos estudados. É provável que essa relação se deva à presença de complexos $\mathrm{Al}$-húmicos nas amostras avaliadas, fato corroborado pela verificação de uma associação direta $\left(r=0,79^{\star *}\right)$ entre os teores de matéria orgânica e os de Al extraídos com oxalato de amônio na TFSA. Além de outras formas de Al, a solução ácida de oxalato de amônio pode extrair compostos de alumínio associados com a matéria orgânica (Parfitt \& Childs, 1988; Courchesne et al., 1999), que ao reagirem com a solução de NaF podem liberar hidroxilas (Gilkes \& Hughes, 1994).

A acentuada correlação negativa obtida no presente trabalho entre o $\mathrm{pH} \mathrm{NaF} \mathrm{e}$ o P-rem (Tabela 10) reitera a utilidade dessa determinação na avaliação da capacidade de adsorção de fosfato de solos sesquioxídicos, concordando com o observado por Singh \& Gilkes (1991), Gilkes \& Hughes (1994) e Bolland et al. 1996. A utilização do $\mathrm{pH} \mathrm{NaF} \mathrm{como} \mathrm{indicador} \mathrm{da} \mathrm{adsorção} \mathrm{de} \mathrm{sulfato} \mathrm{será} \mathrm{discutida} \mathrm{posteriormente.}$

$\mathrm{O}$ incremento dos valores de $\mathrm{pH} \mathrm{NaF}$ com o avanço do intemperismo, como observado pela correlação negativa obtida entre esse atributo e os índices $\mathrm{Ki}$ e $\mathrm{Kr}$ (Tabela 10), indica que a decomposição dos minerais silicatos e o conseqüente acúmulo de óxidos promovem elevações nos valores desse atributo, fato que encontrou respaldo nas relações observadas no presente trabalho entre o pH NaF e os teores de caulinita e óxidos de alumínio. A relação direta existente entre o pH $\mathrm{NaF}$ e 0 estádio de intemperismo dos solos faz com que esse atributo eletroquímico também apresente, como apresentado na Tabela 10, correlação direta com o PESN e a CTA, atributos que também tendem a se expressar com maior intensidade àmedida que o grau de evolução dos solos aumenta.

As relações observadas entre o pH NaF e componentes da fração argila que exercem influência sobre atributos eletroquímicos dos solos estudados, juntamente com a facilidade de determinação desse atributo indicam como promissora a sua utilização como um indicador do comportamento eletroquímico dos solos intemperizados. Do mesmo modo, os resultados observados neste trabalho sugerem como recomendável a inclusão do $\mathrm{pH} \mathrm{NaF}$ entre as determinações laboratoriais envolvidas nos trabalhos de levantamento e classificação de solos das regiões 
tropicais. Contudo, novos trabalhos devem ser realizados envolvendo um maior número de amostras, coletadas preferencialmente em camadas superficiais e subsuperficiais de solos submetidos a diferentes tipos de manejo, de modo a possibilitar a melhor compreensão e utilização pedológica do pH NaF.

\subsection{Adsorção de sulfato}

\subsubsection{Isotermas de adsorção e enxofre remanescente}

A utilização do P-remanescente apresentou-se como um critério adequado para a definição das concentrações de sulfato das soluções utilizadas para a elaboração das isotermas de adsorção. Testes preliminares demonstraram a necessidade da adoção de diferentes conjuntos de concentrações, compatíveis com as capacidades adsortivas das amostras, para que as equações de adsorção pudessem ser devidamente ajustadas aos dados experimentais. Além disso, em se tratando da isoterma de Langmuir, o procedimento adotado pode auxiliar na prevenção de erros de até $50 \%$ ou mais na estimativa da adsorção máxima, que podem ocorrer quando as concentrações das soluções utilizadas para a elaboração da isoterma proporcionam valores adsorvidos que se distanciam desse máximo (Taylor et al., 1996).

No presente trabalho, a avaliação do grau de ajustamento das equações de Langmuir e de Freundlich aos resultados experimentais foi feita utilizando-se os critérios adotados por Mead (1981) e Raven \& Hossner (1994) para a comparação de ajustes não-lineares. Segundo esses critérios, o modelo não linear que melhor se ajusta aos dados experimentais é aquele ao qual está associado o menor quadrado médio residual. Além disso, o modelo será tanto mais adequado quanto mais próximo de zero for o coeficiente linear, mais próximo da unidade for o coeficiente angular e maior for o coeficiente de determinação da equação linear ajustada entre os valores observados e estimados pelo modelo. Além desses critérios, calculou-se também o erro padrão das estimativas para cada equação ajustada, à semelhança do efetuado por Sparks \& Jardine (1984).

A observação dos resultados apresentados na Tabela 12 revela que a equação de Freundlich apresentou melhor ajustamento aos dados em 9 das amostras estudadas. Por outro lado, a equação de Langmuir proporcionou melhor explicação dos 
Tabela 12. Valores dos parâmetros estatísticos utilizados para a comparação dos ajustamentos das equações de Langmuir e Freundlich aos resultados experimentais de adsorção de sulfato para cada solo estudado.

\begin{tabular}{|c|c|c|c|c|c|c|c|c|c|c|c|}
\hline \multirow[b]{2}{*}{ Solo } & \multirow[b]{2}{*}{ Classe } & \multicolumn{5}{|c|}{ Langmuir } & \multicolumn{5}{|c|}{ Freundlich } \\
\hline & & $\mathrm{QMR}^{(1)}$ & E.P. ${ }^{(2)}$ & $a^{(3)}$ & $b^{(3)}$ & $\mathrm{R}^{2(3)}$ & $\mathrm{QMR}^{(1)}$ & E.P. (2) & $a^{(3)}$ & $b^{(3)}$ & $\mathrm{R}^{2(3)}$ \\
\hline 1 & LVwf & 720,1 & 26,8 & 20,9 & 0,95 & 0,9703 & 677,2 & 26,0 & $-9,19$ & 1,02 & 0,9697 \\
\hline 2 & LVef & 377,4 & 19,4 & 5,34 & 0,98 & 0,9839 & 441,4 & 21,0 & $-2,52$ & 1,01 & 0,9808 \\
\hline 3 & LVdf & 3038,9 & 55,1 & 47,4 & 0,91 & 0,9387 & 433,1 & 20,8 & $-2,20$ & 1,00 & 0,9898 \\
\hline 4 & LVwf & 853,3 & 29,2 & 18,6 & 0,96 & 0,9720 & 567,7 & 23,8 & $-8,97$ & 1,02 & 0,9805 \\
\hline 5 & LAw & 346,07 & 18,6 & 6,63 & 0,99 & 0,9872 & 1039,6 & 32,2 & $-13,1$ & 1,03 & 0,9617 \\
\hline 6 & LVd & 556,8 & 23,6 & 12,3 & 0,97 & 0,9855 & 282,8 & 16,8 & $-2,16$ & 1,01 & 0,9920 \\
\hline 7 & LVAd & 114,3 & 10,7 & 4,49 & 0,95 & 0,9383 & 71,9 & 8,5 & 0,68 & 0,99 & 0,9570 \\
\hline 8 & LVAd & 862,4 & 29,4 & $-7,47$ & 1,03 & 0,9582 & 1197,2 & 34,6 & $-6,77$ & 1,02 & 0,9414 \\
\hline 9 & NVef & 653,2 & 25,6 & 7,11 & 0,98 & 0,9701 & 919,2 & 30,3 & $-3,85$ & 1,01 & 0,9569 \\
\hline 10 & PVAd & 108,9 & 10,4 & 5,62 & 0,97 & 0,9823 & 85,4 & 9,2 & $-2,34$ & 1,01 & 0,9850 \\
\hline 11 & PVAd & 178,0 & 13,3 & 3,23 & 0,97 & 0,9201 & 134,9 & 11,6 & $-0,07$ & 1,00 & 0,9384 \\
\hline 12 & PVd & 807,0 & 28,4 & 23,2 & 0,96 & 0,9865 & 684,0 & 26,1 & $-7,85$ & 1,01 & 0,9869 \\
\hline 13 & $P V d$ & 499,7 & 22,4 & 0,48 & 1,00 & 0,9897 & 1167,9 & 34,2 & $-13,6$ & 1,03 & 0,9766 \\
\hline 15 & RQo & 182,0 & 13,5 & 4,34 & 0,96 & 0,9110 & 125,3 & 11,2 & 0,40 & 1,00 & 0,9369 \\
\hline
\end{tabular}

(1) QMR = Quadrado médio residual da análise de variância da regressão não-linear empregada para o ajustamento da equação de adsorção considerada.

(2) E.P. $=$ Erro padrão da estimativa calculado com a seguinte equação : $\quad$ E.P. $=\left[\sum\left(q_{\text {med. }}-q_{\text {est. }}\right)^{2} /(n-2)\right]^{1 / 2}$ em que $q_{\text {med. }}=$ adsorção medida, $q_{\text {est. }}=$ adsorção estimada pela equação considerada e $n=$ número de pares experimentais utilizados para o ajustamento da equação de adsorção.

(3) $\mathrm{a}, \mathrm{b}$ e $\mathrm{R}^{2}=$ respectivos coeficientes linear, angular e de determinação da equação de regressão $\mathrm{y}=\mathrm{a}+\mathrm{bx}$, em que y corresponde à quantidade adsorvida de sulfato determinada experimentalmente $\mathrm{e} x$ àquantidade adsorvida de sulfato estimada pela equação de ads orção considerada. 
resultados de adsorção obtidos para as amostras 2, 5, 8, 9 e 13. Para a amostra 14, nenhum dos modelos se ajustou adequadamente aos dados. Tal fato provavelmente está relacionado à composição mineralógica de sua fração argila que, com o já mencionado, apresenta marcantes diferenças qualitativas em relação æ̀s das demais amostras estudadas.

Vários trabalhos envolvendo o ajustamento de dados de adsorção de sulfato por solos e minerais a equações de adsorção constataram a ausência de um patamar nítido nas curvas de adsorção e, portanto, a melhor adequação da equação de Freundlich para a descrição de isotermas de adsorção do referido ânion. Dentre eles podem ser citados os trabalhos de Chao et al. (1962), Bornemisza \& Llanos (1967), Singh (1984), Rao \& Sridharan (1984), Bolan et al. (1988), Marcano-Martinez \& McBride (1989), Bolan et al. (1993) e Agbenin (1997). A representação gráfica dos ajustamentos das equações de adsorção aos dados experimentais é apresentada nas Figuras 17 a 20.
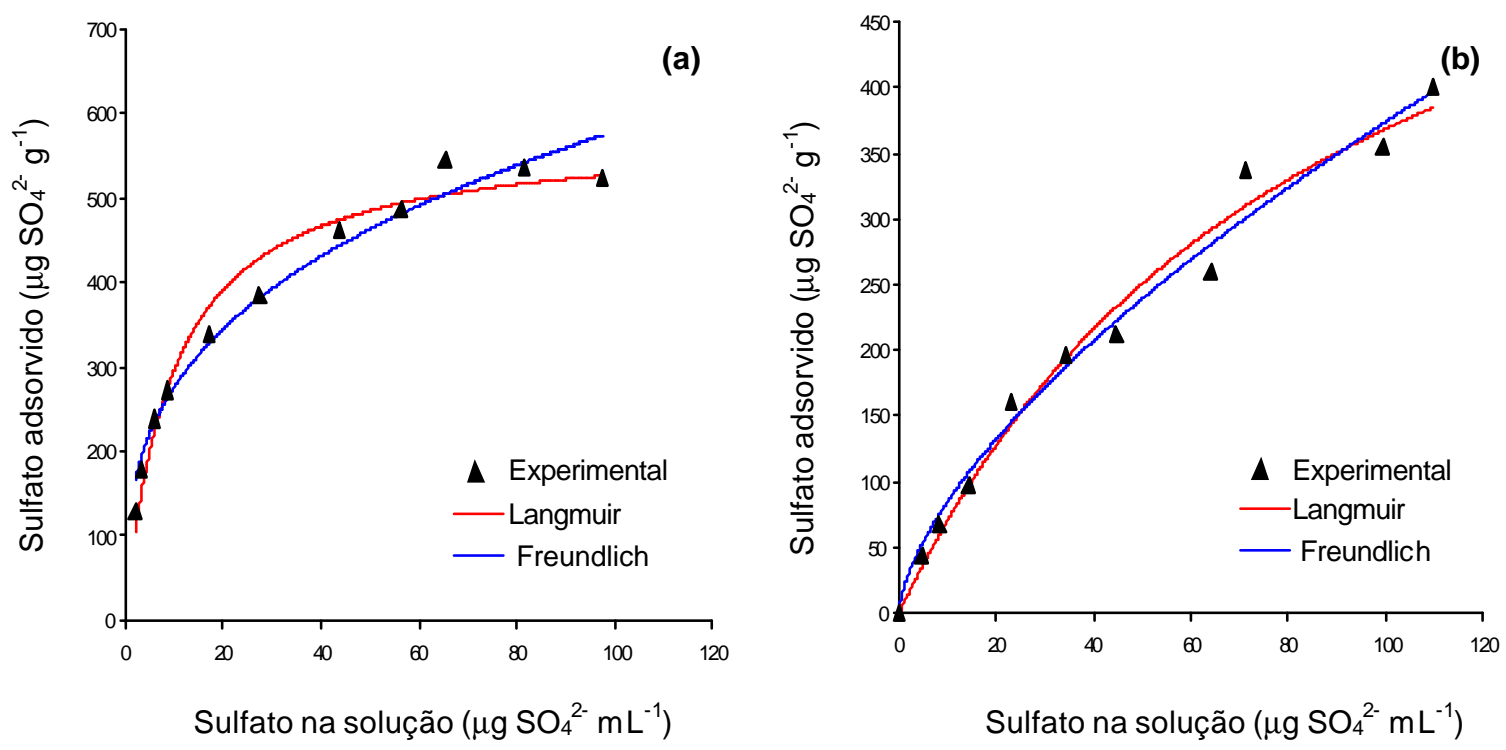

Figura 17 - Quantidades de sulfato adsorvidas pelo Latossolo Vermelho Acriférrico (amostra 1) (a) e pelo Latossolo Vermelho Eutroférrico (amostra 2) (b) em função de sua concentração na solução de equilíbrio e curvas obtidas a partir de valores estimados com as equações de Langmuir e Freundlich. 


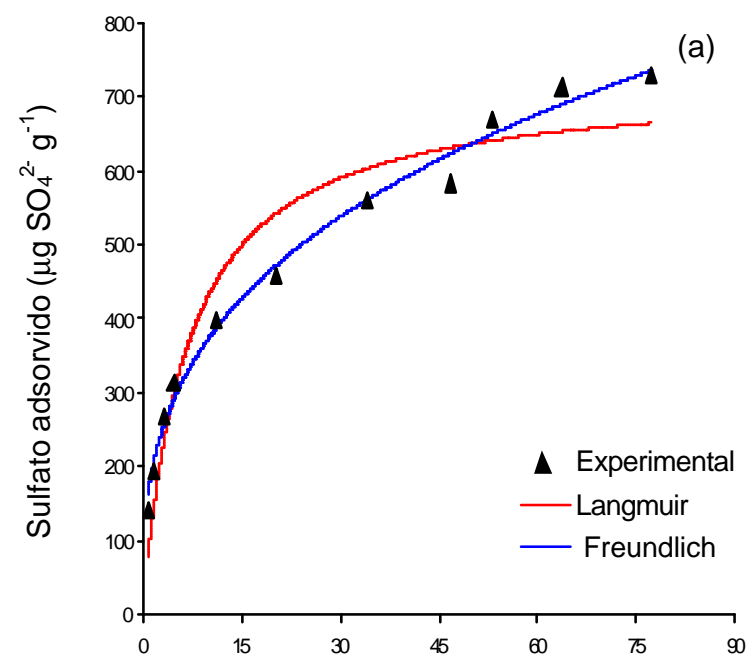

Sulfato na solução ( $\left.\mu \mathrm{g} \mathrm{SO}{ }_{4}^{2--} \mathrm{mL}^{-1}\right)$

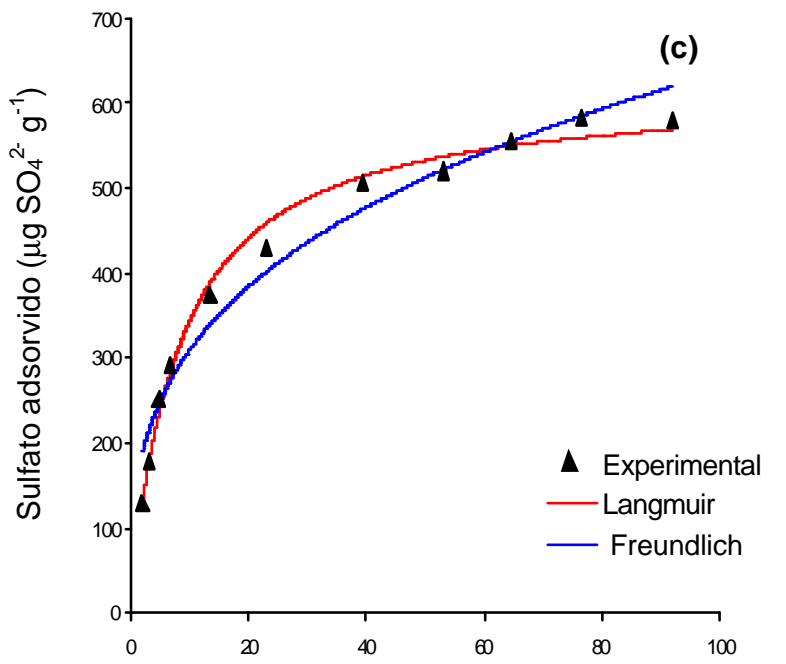

Sulfato na solução $\left(\mu \mathrm{g} \mathrm{SO}_{4}{ }^{2-} \mathrm{mL}^{-1}\right)$
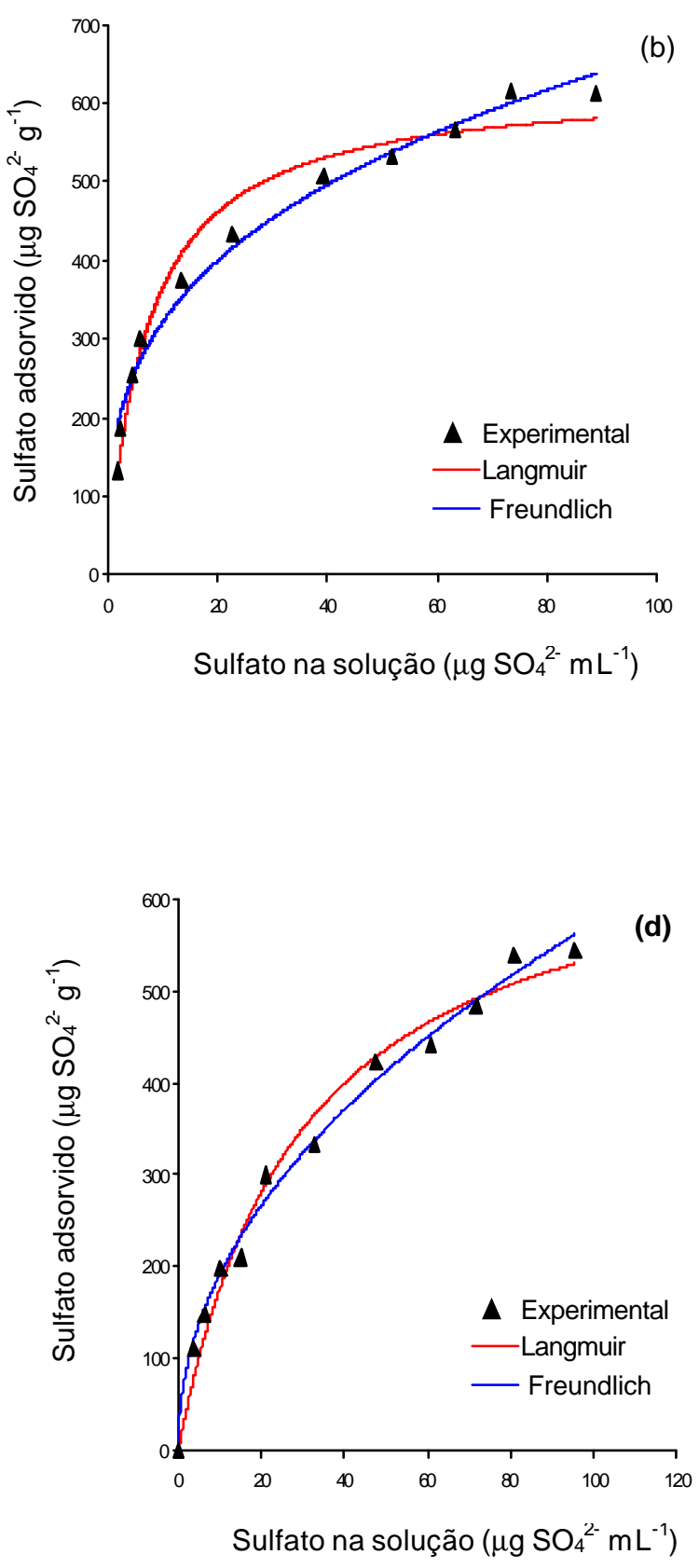

Figura 18 - Quantidades de sulfato adsorvidas pelo Latossolo Vermelho Distroférrico (amostra 3) (a), Latossolo Vermelho Acriférrico (amostra 4) (b), Latossolo Amarelo Ácrico (amostra 5) (c) e Latossolo Vermelho Distrófico (amostra 6) (d) em função de sua concentração na solução de equilíbrio e curvas obtidas a partir de valores estimados com as equações de Langmuir e Freundlich. 

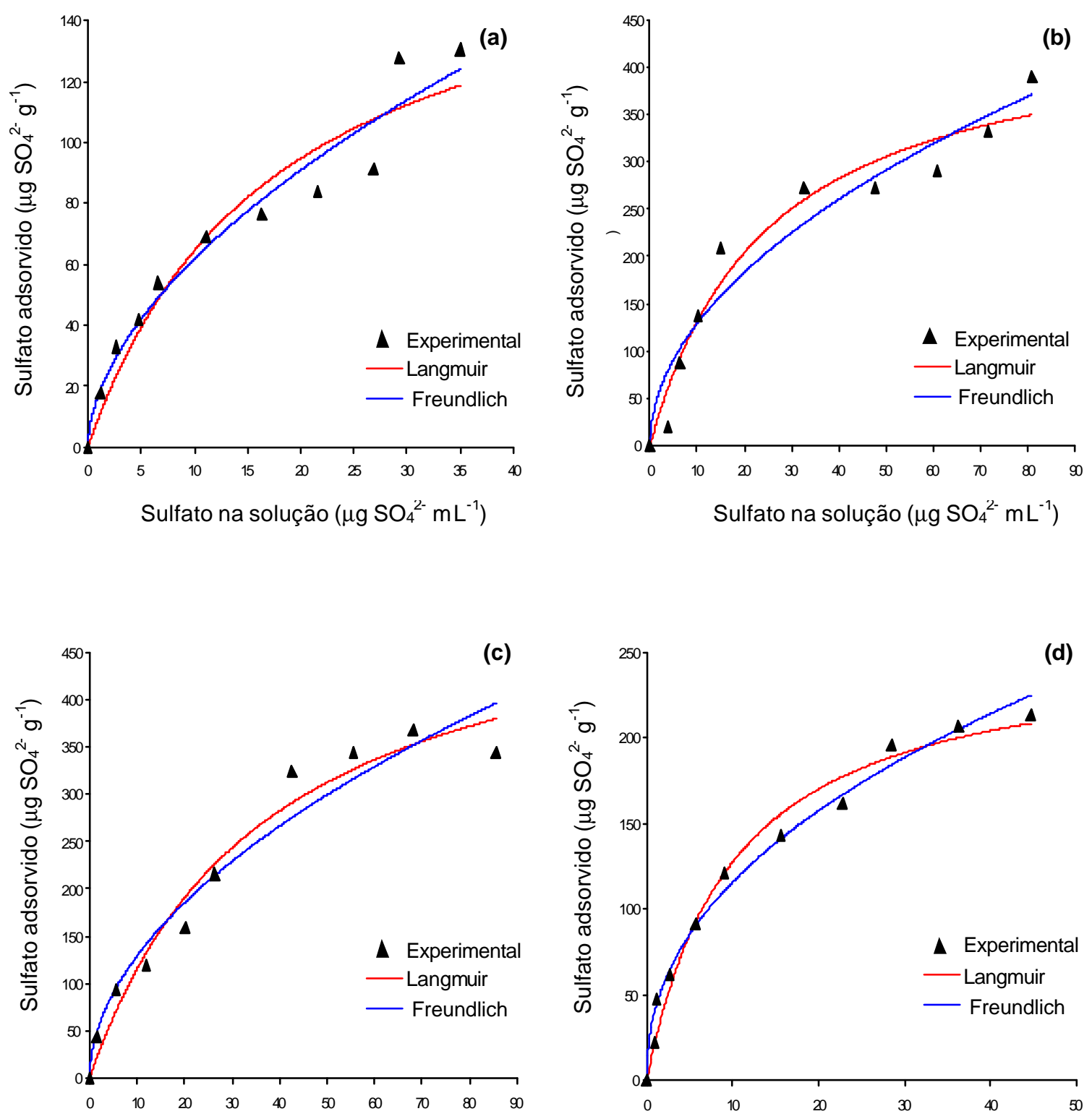

Sulfato na solução ( $\left.\mu \mathrm{g} \mathrm{SO}{ }_{4}{ }^{2-} \mathrm{mL}^{-1}\right)$

Sulfato na solução $\left(\mu \mathrm{g} \mathrm{SO}_{4}{ }^{2-} \mathrm{mL}^{-1}\right)$

Figura 19 - Quantidades de sulfato adsorvidas pelo Latossolo Vermelho-Amarelo Distrófico (amostra 7) (a), Latossolo Vermelho-Amarelo Distrófico (amostra 8) (b), Nitossolo Vermelho Eutroférrico (amostra 9) (c) e Argissolo Vermelho-Amarelo Distroférrico (amostra 10) (d) em função de sua concentração na solução de equilíbrio e curvas obtidas a partir de valores estimados com as equações de Langmuir e Freundlich. 

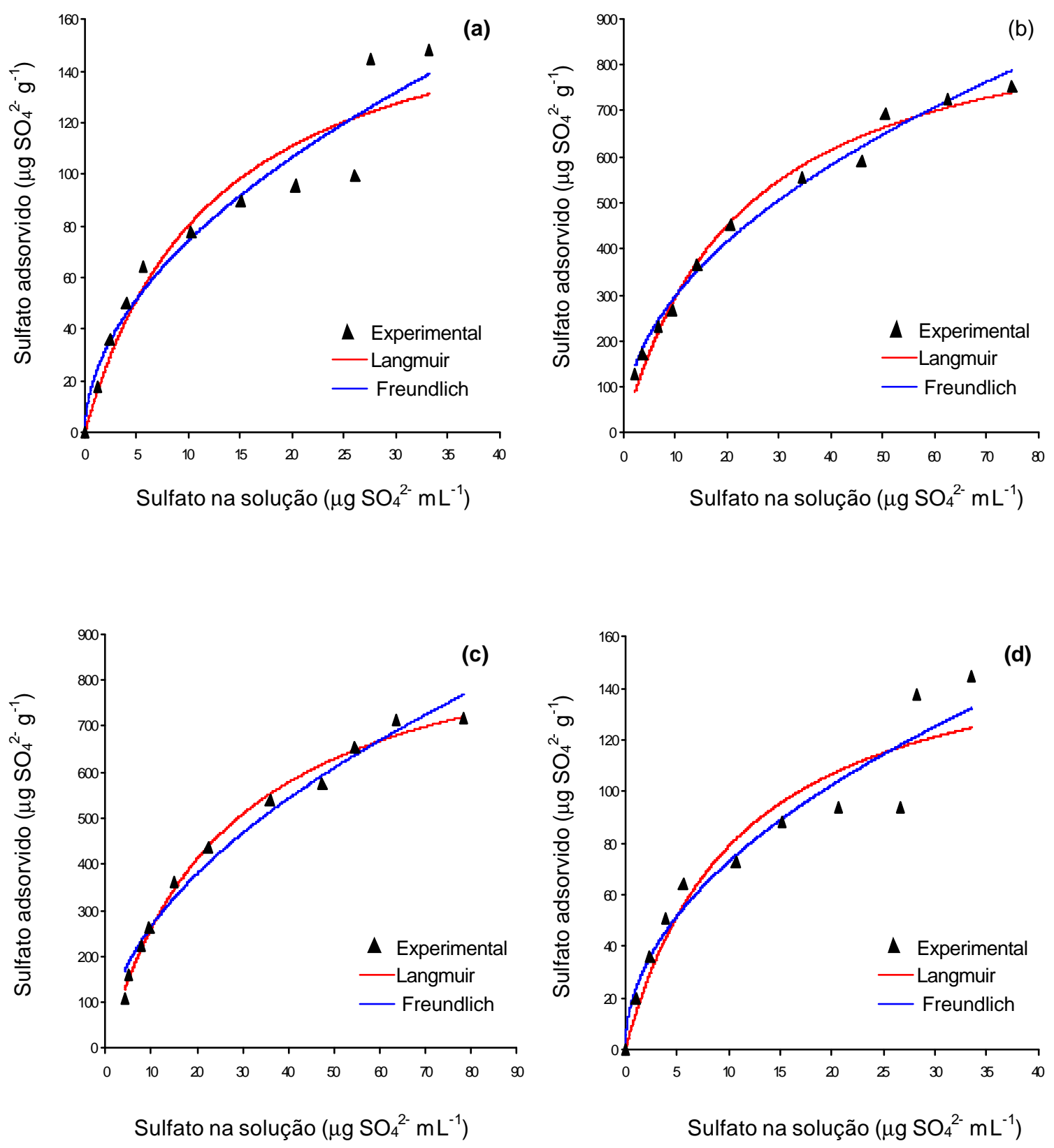

Figura 20 - Quantidades de sulfato adsorvidas pelo Argissolo Vermelho-Amarelo Distrófico (amostra 11) (a), Argissolo Vermelho Distrófico (amostra 12) (b), Argissolo Vermelho Distrófico (amostra 13) (c) e Neossolo Quartzarênico Órtico (amostra 15) (d) em função de sua concentração na solução de equilíbrio e curvas obtidas a partir de valores estimados com as equações de Langmuir e Freundlich. 
A capacidade máxima de adsorção de sulfato, estimada pelo parâmetro b da equação de Langmuir (Tabela 13), variou de 165,8 a 970,4 $\mu \mathrm{g} \mathrm{SO}_{4}{ }^{2-} \mathrm{g}^{-1}$, com valor médio para o conjunto das amostras de $545 \mu \mathrm{g} \mathrm{SO}_{4}{ }^{2-} \mathrm{g}^{-1}$. A constante $\mathrm{k}$ dessa equação, associada à afinidade da fase sólida pelo adsorvato, variou de 0,0163 a

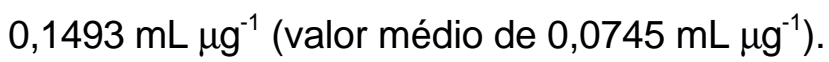

Os valores do parâmetro $n$ da equação de Freundlich variaram de 1,7247 a 3,1859 , com média de 2,3009. A variável $k_{\triangleleft}$ (Chen et al., 1999), utilizada como um índice de adsorção de sulfato em substituição ao parâmetro $k$ de Freundlich, apresentou valores que variaram entre 3,8 e 17,9 mL g $\mathrm{g}^{-1}$, que foram calculados com o emprego da equação (10) adotando-se o valor de $30 \mu \mathrm{g} \mathrm{SO}_{4}{ }^{2-} \mathrm{mL}^{-1}$ como sendo a máxima concentração de sulfato comum a todas as soluções de equilíbrio observadas após elaboração das isotermas de adsorção. Desse modo, variável $k_{u}$ será designada doravante constante $\mathrm{k}_{30}$.

O S-rem, atributo que normalmente apresenta estreita correlação com a capacidade máxima de adsorção de sulfato (Alvarez V. et al., 1983), variou nas determinações efetuadas na TFSA de $6,8 \mu \mathrm{g} \mathrm{SO}_{4}{ }^{2-} \mathrm{mL}^{-1}$ no Latossolo Amarelo Ácrico a $47,4 \mu \mathrm{g} \mathrm{SO}_{4}{ }^{2-} \mathrm{mL}^{-1}$ no Neossolo Quartzarênico Órtico. Nas determinações efetuadas na fração argila, os valores desse atributo variaram de 1,6 no Latossolo Amarelo Ácrico a 26,1 $\mu \mathrm{g} \mathrm{SO}_{4}{ }^{2-} \mathrm{mL}^{-1}$ para o Argissolo Vermelho-Amarelo Distrófico (amostra 11).

A análise dos dados apresentados na Tabela 13 permite verificar que o $\mathrm{P}$ remanescente apresenta maior sensibilidade de discriminação de capacidades de adsorção aniônica que o S remanescente, haja vista que sua variabilidade nas amostras estudadas, expressa por seu coeficiente de variação, foi cerca de 2,6 vezes maior que a observada para o S-rem medido na TFSA, fato que reitera sua utilidade na definição das faixas de concentração a serem utilizadas na elaboração das isotermas de adsorção, como proposto por Alvarez V. et al. (2000).

$\mathrm{Na}$ etapa de determinação das isotermas de adsorção, observou-se que as amostras 2, 6, 8 e 9 apresentaram significativa liberação de sulfato. Tal fato fez com que fosse necessária a correção das concentrações de equilíbrio, descontando-se, em cada ponto da isoterma, o valor da concentração de sulfato verificado para a 
Tabela 13. Valores de fósforo remanescente (P-rem.), enxofre remanescente (S-rem.), das estimativas dos parâmetros das equações de Langmuir e Freundlich ajustadas aos resultados experimentais de adsorção de sulfato com seus respectivos intervalos de confiança ${ }^{(1)}$ e valores da constante $k_{30}$.

\begin{tabular}{|c|c|c|c|c|c|c|c|c|c|}
\hline & \multirow{3}{*}{ Classe } & P-rem. ${ }^{(2)}$ & \multicolumn{2}{|c|}{ S-rem. ${ }^{(3)}$} & \multicolumn{2}{|c|}{ Langmuir } & \multicolumn{2}{|c|}{ Freundlich } & \multirow{3}{*}{$\frac{\mathrm{k}_{80}}{\mathrm{mLg}^{-1}}$} \\
\hline & & \multirow{2}{*}{$\mu \mathrm{g} \mathrm{mL}^{-1}$} & TFSA & Argila & \multirow{2}{*}{$\mathrm{k}\left(\mathrm{mL} \mu \mathrm{g}^{-1}\right)$} & \multirow{2}{*}{$\mathrm{b}\left(\mu \mathrm{g} \mathrm{g}^{-1}\right)$} & \multirow{2}{*}{$\mathrm{k}\left(\mu \mathrm{g}^{(1-1 / n)} \mathrm{g}^{-1} \mathrm{~mL} \mathrm{~L}^{1 / n}\right)$} & \multirow{2}{*}{$\mathrm{n}$} & \\
\hline & & & \multicolumn{2}{|c|}{$\mu \mathrm{g} \mathrm{SO}_{4}{ }^{2-} \mathrm{mL}^{-1}$} & & & & & \\
\hline 1 & LV & 1,0 & 11,4 & 19,3 & $0,1052(0,0884-0,1220)$ & $577,3(554,1-600,4)$ & $131,5(118,2-144,7)$ & $3,1076(2,8583-3,3568)$ & 13,1 \\
\hline 2 & LV & 3,1 & 33,4 & 12,6 & $0,0163(0,0102-0,0224)$ & $677,6(552,3-803,0)$ & $29,9(19,0-40,7)$ & $1,7247(1,4684-1,9810)$ & 7,2 \\
\hline 3 & LV & 4,1 & 13,0 & 19,9 & $0,1493(0,1093-0,1893)$ & $721,5(676,3-766,6)$ & $174,3(164,0-184,7)$ & $3,0199(2,8744-3,1654)$ & 17,9 \\
\hline 4 & LV & 0,3 & 8,2 & 6,1 & $0,1384(0,1172-0,1596)$ & $627,7(604,7-650,6)$ & $155,9(143,8-168,0)$ & $3,1859(2,9805-3,3912)$ & 15,1 \\
\hline 5 & LA & 0,1 & 6,8 & 1,6 & $0,1245(0,1123-0,1367)$ & $618,2(603,2-633,3)$ & $149,8(133,5-166,1)$ & $3,1837(2,8969-3,4705)$ & 14,5 \\
\hline 6 & LV & 3,8 & 33,4 & 14,9 & $0,0340(0,0235-0,0446)$ & $692,5(610,4-774,5)$ & $63,7(51,9-75,6)$ & $2,0960(1,8948-2,2971)$ & 10,8 \\
\hline 7 & LVA & 36,1 & 41,9 & 20,2 & $0,0564(0,0270-0,0858)$ & $178,8(135,9-221,6)$ & $17,2(12,6-21,7)$ & $1,7962(1,5225-2,0701)$ & 3,8 \\
\hline 8 & LVA & 7,7 & 37,1 & 19,1 & $0,0405(0,0139-0,0671)$ & $456,1(347,0-565,3)$ & $40,6 \quad(13,7-67,5)$ & $1,9853(1,3280-2,6425)$ & 7,5 \\
\hline 10 & PVA & 21,8 & 34,1 & 23,7 & $0,0999(0,0805-0,1193)$ & $255,3(238,6-271,9)$ & $41,7(37,4-46,1)$ & $2,2563(2,0929-2,4196)$ & 6,3 \\
\hline 11 & PVA & 36,1 & 43,9 & 26,1 & $0,0800(0,0461-0,1139)$ & $180,3(149,3-211,2)$ & $22,3(17,1-27,6)$ & $1,9181(1,6352-2,2010)$ & 4,4 \\
\hline 12 & PV & 2,1 & 19,3 & 6,9 & $0,0438(0,0375-0,0501)$ & $965,0(911,7-1018,3)$ & $97,3(87,3-107,2)$ & $2,0634(1,9491-2,1778)$ & 16,9 \\
\hline 13 & PV & 1,5 & 17,7 & 12,2 & $0,0367(0,0324-0,0410)$ & $970,4(923,8-1017,1)$ & $80,5(68,7-92,2)$ & $1,9337(1,7917-2,0756)$ & 15,6 \\
\hline 15 & $\mathrm{RQ}$ & 43,0 & 47,4 & 20,8 & $0,0903(0,0508-0,1297)$ & $165,8(138,2-193,4)$ & $23,3(18,0-28,7)$ & $2,0250(1,7204-2,3297)$ & 4,2 \\
\hline
\end{tabular}

(1) Intervalos estabelecidos com coeficiente de confiança igual a 95\%.

(2) P-rem: fósforo que permanece em solução após a agitação por 1 hora da TFSA com uma solução contendo $60 \mathrm{~g} \mathrm{P} \mathrm{mL}^{-1}$ na proporção solo:solução de 1: 10 (Alvarez V. \& Fonseca, 1990).

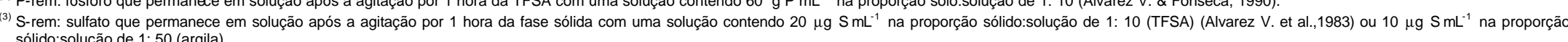


concentração de equilíbrio referente ao primeiro ponto, no qual não havia sido feita a adição do referido íon. Como anteriormente mencionado, as referidas amostras foram coletadas em camadas subsuperficiais de solos cultivados. Desse modo, é possível que os teores de sulfato, observados nestas amostras, sejam resultantes da lixiviação e posterior acúmulo do enxofre aplicado na camada arável por meio de práticas de adubação e correção do solo.

Embora a avaliação do ajustamento das equações de adsorção tenha indicado que para as amostras 2, 8 e 9 os dados experimentais tenham sido mais bem explicados pelo modelo de Langmuir, a visualização gráfica dos resultados (Figuras 17b, 19b e 19c) não permite a identificação do platô característico do comportamento descrito pelo referido modelo. Além disso, os intervalos de confiança obtidos para o parâmetro b de Langmuir nesses solos apresentaram elevada amplitude (Tabela 13). É possível que liberação de sulfato por essas amostras tenha relação com esse fato, como sugerido por Rhoades et al. (1970) e Scott et al. (1975) em estudos de adsorção de boro.

Nas amostras estudadas em que não houve significativa liberação de sulfato verificou-se boa concordância entre as avaliações gráfica e estatística da adequação dos modelos de Langmuir e Freundlich. Em relação à isoterma de Langmuir, Harter (1984) afirma ainda que a verificação da concordância entre o formato da curva experimental e da curva teórica é muito importante quando se considera a utilização desse modelo em estudos de adsorção, visto que quando as isotermas não apresentam um comportamento semelhante ao da curva teórica descrita pela referida equação, erros da ordem de $50 \%$ ou mais podem ser cometidos na estimativa da capacidade máxima de adsorção.

No caso da amostra 6, embora seja observada uma concordância gráfica (Figura 18d) e estatística (Tabela 12) quanto ao melhor ajuste da equação de Freundlich, acredita-se que, à semelhança do ve rificado para as amostras 2, 8 e 9, a liberação de sulfato tenha também influenciado as magnitudes das estimativas dos parâmetros k e n, uma vez que ao considerar-se todas as amostras avaliadas, pode-se constatar que as maiores discrepâncias quanto æ̀ tend ências apresentadas pelos parâmetros $b$ de Langmuir e $k$ de Freundlich são verificadas nas amostras que mais liberaram sulfato para a solução de equilíbrio. 
Considerando-se que nem todos os índices de adsorção de sulfato obtidos no presente trabalho foram representativos do fenômeno, decidiu-se por excluir das análises de correlação linear simples, estabelecidas entre os referidos índices e atributos dos solos estudados, os dados referentes æ̀ amostras 2, 6, 8 e 9.

Para as demais amostras e com base no exposto, foram considerados como índices de adsorção de sulfato o parâmetro $\mathrm{n}$ de Freundlich, a constante $\aleph_{\$_{0}}$ e o enxofre remanescente determinado na TFSA e na argila.

\subsubsection{Relações entre a adsorção de sulfato e atributos dos solos}

\subsubsection{Granulometria}

A importância da argila no fenômeno da adsorção é bastante reconhecida (Serrano et al., 1999) estando basicamente associada à sua maior superfície reativa, em comparação com as demais frações do solo.

No presente estudo, a adsorção de sulfato apresentou acentuada correlação com o teor de argila (Tabela 14). Embora o teor de silte tenha apresentado relação direta com a adsorção, a soma dos teores de silte e argila não promoveu um grande incremento nos coeficientes de correlação.

Tabela 14. Coeficientes de correlação linear simples entre a constante $k_{30}$, enxofre remanescente determinado na TFSA (S-rem) e atributos granulométricos das amostras estudadas $(n=10)$.

\begin{tabular}{lccc}
\hline & Silte & Argila & Argila + Silte \\
\cline { 2 - 4 } $\mathrm{k}_{30}$ & $0,72^{*}$ & $0,82^{* *}$ & $0,85^{* *}$ \\
S-rem & $-0,75^{*}$ & $-0,82^{* *}$ & $-0,85^{* *}$ \\
\hline${ }^{* *} \mathrm{e}^{*}$ significativo à5\% e 1\% de probabilidade pelo teste t, respectivamente.
\end{tabular}


A influência do aspecto qualitativo da argila, que muitas vezes supera o quantitativo, foi avaliada analisando-se os teores de sulfato adsorvido pela fração argila de alguns dos solos estudados. As quantidades de sulfato retidas pelas amostras foram calculadas a partir dos valores de S-rem determinados diretamente na fração argila, subtraindo-se os mesmos da concentração inicial de sulfato da solução aplicada. Os dados obtidos foram analisados mediante aplicação do teste $F$ àanálise de variância seguido do teste de comparações múltiplas de Tukey (Figura 21).

Os teores de sulfato adsorvidos variaram de 193 e $1420 \mu \mathrm{g} \mathrm{g}^{-1}$ de argila, sendo a maior capacidade adsortiva observada para o Latossolo Amarelo Ácrico (amostra 5) e a menor para o Argissolo Vermelho-Amarelo Distrófico (amostra 11). Esses resultados apresentam relação direta com a composição mineralógica das fases adsorventes e indicam a destacada importância da gibbsita, goethita e óxidos de alumínio mal cristalizados, que juntos perfazem cerca de $60 \%$ da composição da fração argila do Latossolo Amarelo Ácrico, como adsorvedores de sulfato. Por outro lado, a baixa capacidade adsortiva observada para a fração argila do Argissolo Vermelho-Amarelo Distrófico deve-se basicamente à composição da mesma, que apresenta cerca de $80 \%$ de caulinita, mineral que, ao contrário dos óxidos de ferro e de alumínio, possui baixa capacidade de adsorção de sulfato como destacado no trabalho de Aylmore et al. (1967).

O aspecto da importância qualitativa da fração argila em relação à adsorção pode ainda ser ressaltado considerando-se o Latossolo Amarelo Ácrico que, mesmo apresentando textura média, encontra-se entre os solos com maior capacidade de adsorção de sulfato dentre os estudados, sendo capaz de adsorver quantidades do referido ânion similares æ̀s adsorvidas pelo Latossolo Vermelho Acriférrico (amostra 4), o qual apresenta o dobro do teor de argila (Tabela 2). 


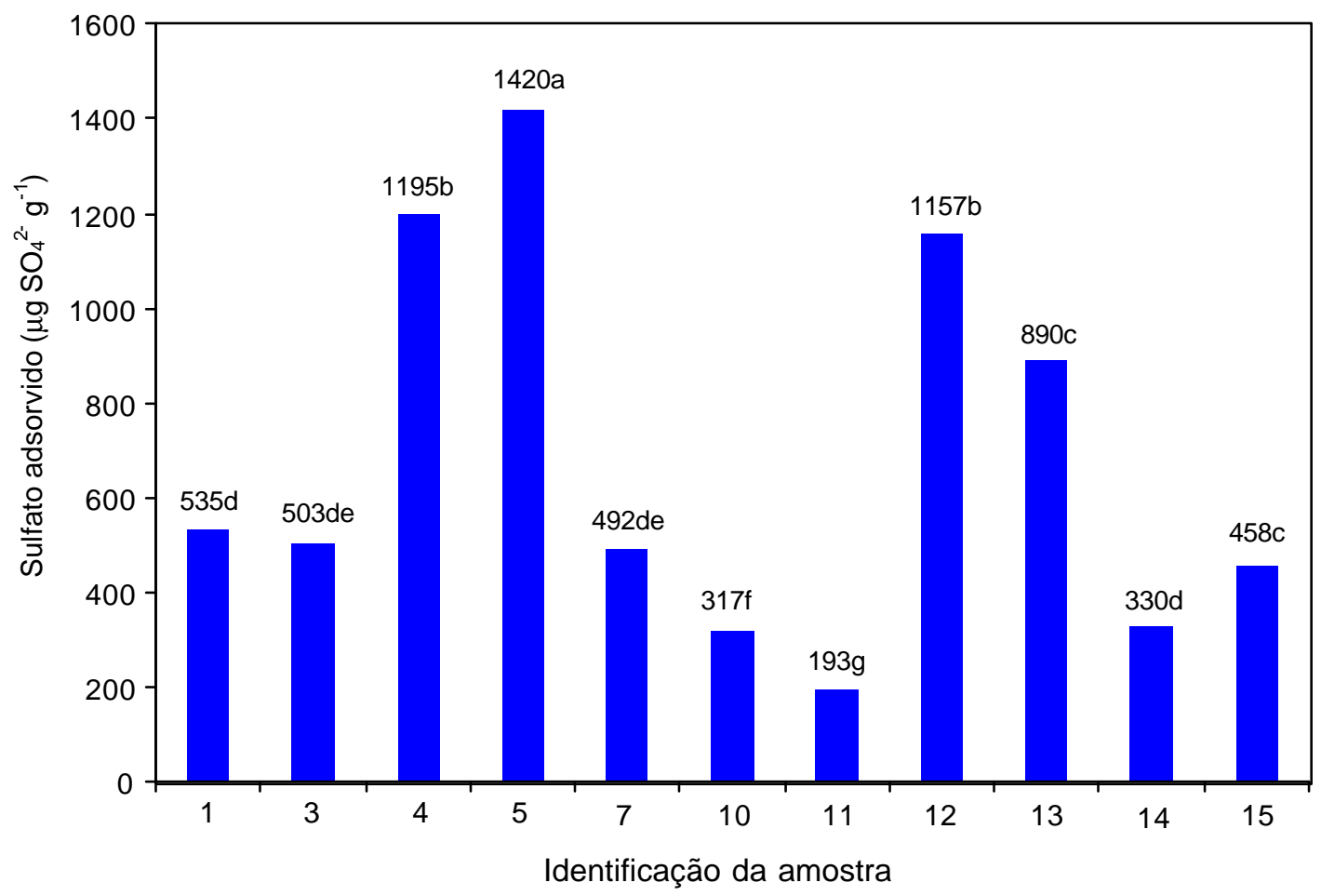

Figura 21 - Quantidades de sulfato adsorvidas pela fração argila em alguns dos solos estudados. Valores seguidos por uma mesma letra não diferem entre si a

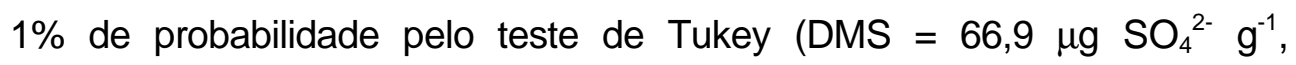
C.V. $=2,8 \%$ ).

\subsubsection{Formas de ferro e alumínio}

Os trabalhos que tratam da influência de formas de ferro e alumínio sobre a capacidade adsortiva de sulfato destacam, em sua grande maioria, a associação entre a adsorção do referido íon e os teores de alumínio vinculados aos óxidos, os quais são obtidos por meio de técnicas de dissolução seletiva. À exceção da destacada associação entre a adsorção de sulfato e o teor de ferro vinculado aos óxidos cristalinos $\left(\mathrm{Fe}_{\mathrm{DC}}-\mathrm{Fe}_{\mathrm{OXA}}\right)$, verificada por Johnson \& Todd (1983) para solos florestais norte americanos, trabalhos como os de Fuller et al. (1985), Harrinson et al. (1989) e McDonald \& Hart Jr. (1990) realizados com solos dos Estados Unidos, Courchesne \& Hendershot (1989) e Bhatti et al. (1997) para solos canadenses e Dolui \& Chakrabarti 
(1998) para solos da Índia demonstraram a acentuada associação entre a adsorção de sulfato e os teores de alumínio avaliados por diferentes extratores, com certa unanimidade para o alumínio associado æ̀ f ormas mal cristalizadas.

No presente trabalho, verificou-se que os índices de adsorção de sulfato avaliados apresentaram, em geral, correlações mais expressivas com os teores de alumínio obtidos com diferentes extratores (Tabela 15). Esse relacionamento direto pode estar associado à vinculação dos teores de alumínio obtidos pelos diferentes métodos de extração com a gibbsita e com os óxidos de Al mal cristalizados presentes nas amostras.

Tabela 15 Coeficientes de correlação linear simples entre o enxofre remanescente determinado na TFSA (S-rem), constante $k_{30}$, parâmetro $n$ da equação de Freundlich e teores de Fe e Al avaliados por diferentes extratores $(n=10)$.

\begin{tabular}{|c|c|c|c|}
\hline & S - rem & $\mathrm{k}_{30}$ & $\mathrm{n}$ \\
\hline $\mathrm{Fe}-\mathrm{H}_{2} \mathrm{SO}_{4}$ & $-0,81^{* *}$ & $0,71^{*}$ & $0,79^{* *}$ \\
\hline FedC - TFSA & $-0,81^{* *}$ & $0,75^{\star}$ & $0,77^{* *}$ \\
\hline FeoxA - TFSA & $-0,70^{*}$ & $0,64^{*}$ & $0,67^{*}$ \\
\hline $\mathrm{Al}-\mathrm{H}_{2} \mathrm{SO}_{4}$ & $-0,91^{\star *}$ & $0,86^{* *}$ & $0,66^{*}$ \\
\hline$A_{D C}-T F S A$ & $-0,91^{\star *}$ & $0,85^{\star *}$ & $0,59^{\text {ns }}$ \\
\hline AloxA - TFSA & $-0,82^{* *}$ & $0,65^{\star *}$ & $0,83^{* *}$ \\
\hline
\end{tabular}

Apesar da escassez de referências específicas para associação entre a adsorção de sulfato e teores de alumínio para solos das regiões tropicais, um destacado papel desses compostos sobre a adsorção de fosfato pôde também ser observado em solos sesquioxídicos da Austrália por Gilkes \& Singh (1991), Gilkes \& Hughes (1994) e Bolland et al. (1996). 
A análise dos coeficientes de correlação apresentados na Tabela 15 permite que se verifique uma contundente associação inversa entre o S-rem e o teor de Al obtido por meio do ataque sulfúrico, que encontra respaldo nas dispersões dos pontos experimentais (Figura 22). Além do caráter informativo dessa associação, deve-se destacar a utilidade prática do S-rem como um índice de adsorção de sulfato, tanto pela elevada correlação apresentada por esse atributo com a constante $k_{30}\left(r=-0,91^{* *}\right)$ quanto pela rapidez e facilidade associadas àsua determinação experimental.

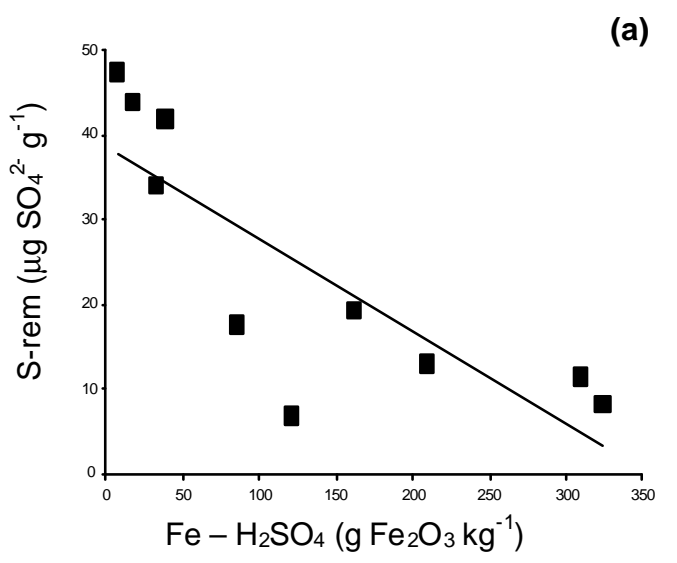

(c)

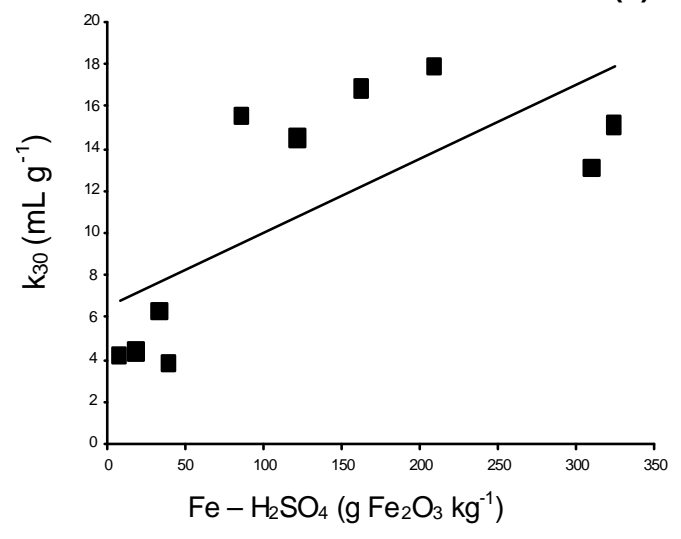

(b)

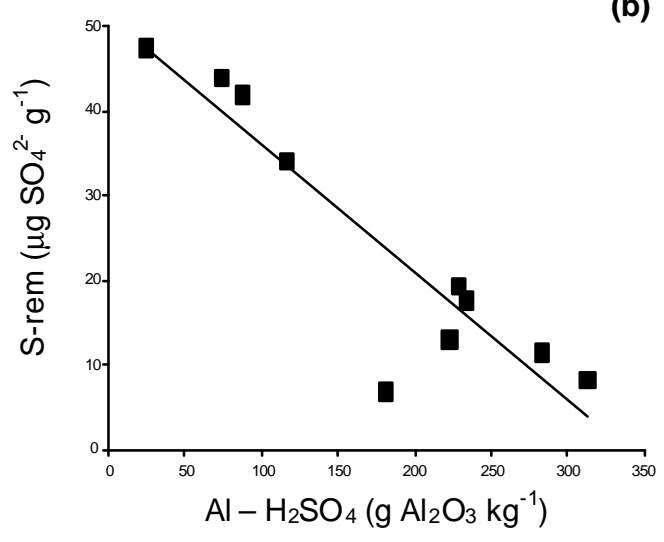

(d)

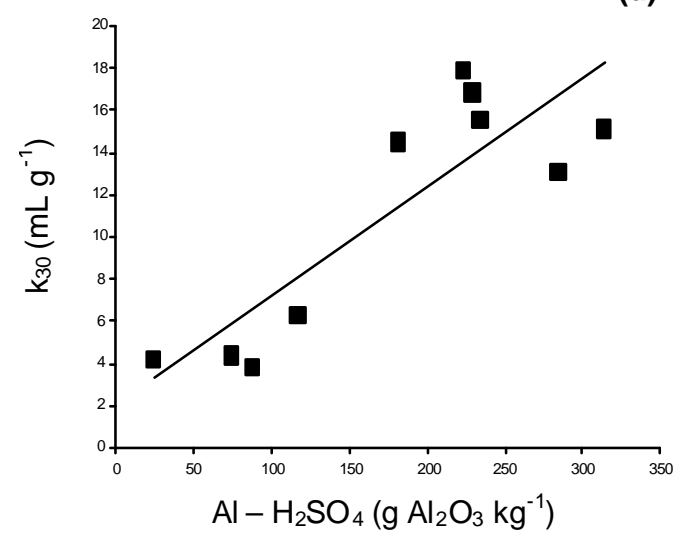

Figura 22 - Relações entre índices de adsorção de sulfato e teores de Fe e Al obtidos por meio de ataque sulfúrico. (a) = S-rem e Fe; (b) = S-rem e Al; (c) = $\mathrm{k}_{30}$ e $\mathrm{Fe},(\mathrm{d}) \mathrm{k}_{30}$ e Al. 
Apesar do caráter empírico da equação de Freundlich, seu parâmetro $n$ pode ser utilizado como um indicador da afinidade da fase sólida pelo adsorbato (Sposito, 1980; Colombo et al., 1994). De fato, apesar de um ajustamento inferior aos dados de adsorção de sulfato apresentado pela equação de Langmuir, que apresenta fundamentação físico-química (Sposito, 1979), observou-se, no presente trabalho uma estreita correlação entre o parâmetro k dessa equação, relacionado com a afinidade da fase sólida pelo adsorbato e o parâmetro $n$ da equação de Freundlich $\quad\left(r=0,86^{* *}\right)$. Desse modo, a associação direta mais acentuada observada entre a estimativa do parâmetro $n$ da equação de Freundlich e o teor de Al vinculado aos compostos mal cristalizados (Tabela 15) indica a elevada afinidade desses compostos pelo íon sulfato.

\subsubsection{Atributos eletroquímicos}

A CTA e o $\mathrm{pH} \mathrm{NaF}$ foram os atributos eletroquímicos mais bem correlacionados com os índices de adsorção de sulfato (Tabela 16).

Tabela 16. Coeficientes de correlação linear simples entre o enxofre remanescente (S-rem.) determinado na TFSA, a constante $k_{30}$, o parâmetro $n$ da equação de Freundlich e os valores de $\mathrm{pH} \mathrm{NaF} \mathrm{e} \mathrm{CTA}(n=10)$.

\begin{tabular}{lccc}
\hline & S - rem & $k_{30}$ & $\mathrm{n}$ \\
\cline { 2 - 4 } $\mathrm{pH} \mathrm{NaF}-$ TFSA & $-0,96^{* *}$ & $0,82^{* *}$ & $0,86^{* *}$ \\
CTA & $-0,94^{* *}$ & $0,81^{* *}$ & $0,75^{\star *}$ \\
\hline
\end{tabular}

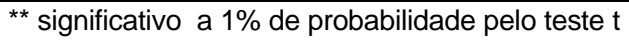

À primeira vista, as correlações observadas poderiam reiterar a polêmica em relação ao único mecanismo envolvido com a adsorção de sulfato pelo solo. De um lado, a estreita relação entre a CTA e índices de adsorção sugere o envolvimento de interações eletrostáticas na retenção desse ânion como destacado por Zhang \& Sparks (1990), Marsh et al. (1987) e Charlet et al. (1993); de outro, a direta associação verificada com o $\mathrm{pH} \mathrm{NaF}$ indica a possibilidade de ocorrência de troca de ligantes entre 
os grupos $\mathrm{OH}^{-}$de superfície e o íon $\mathrm{SO}_{4}{ }^{2-}$, mecanismo sugerido, dentre outros, por Parfitt (1978), Rajan (1978) e Guadalix \& Pardo (1991). Contudo, embora as relações avaliadas no presente trabalho entre $\mathrm{o} \mathrm{pH} \mathrm{NaF}$ e a composição mineralógica das amostras estudadas sugiram que os elevados valores de $\mathrm{pH}$ das suspensões TFSA$\mathrm{NaF}$ possam, em grande parte, serem devidos ao deslocamento de grupos $-\mathrm{OH}$ de superfície em virtude da troca com íons F (Zhang \& Yu, 1997), a correlação direta observada entre o $\mathrm{pH} \mathrm{NaF} \mathrm{e} \mathrm{a} \mathrm{CTA}\left(r=0,76^{* *}\right)$ não possibilita que informações mais conclusivas sejam obtidas. Ademais, tanto $\mathrm{o} \mathrm{pH}$ NaF quanto a CTA tendem a aumentarem com o avanço do intemperismo, fato que também ocorre com a adsorção de sulfato.

Incertezas à parte, deve -se destacar a excelente relação linear verificada entre o $\mathrm{pH} \mathrm{NaF}$ e o S-rem (Figura 23), fato que indica a potencialidade do uso do $\mathrm{pH} \mathrm{NaF}$ como um índice de adsorção de sulfato, à semelhança do observado por Camps Arbestain et al. (1999) para solos espanhóis. Além da elevada capacidade de predição da adsorção de sulfato, o pH NaF apresenta como maior vantagem em relação ao método das isotermas e ao próprio S-rem maior rapidez nas avaliações.

Embora no presente trabalho, tenha-se efetuado a agitação das suspensões TFSA-solução pelo período de 1 hora, em conformidade com o trabalho de Bolland et al. (1996), é possível ainda um aumento no rendimento dessa determinação reduzindose o tempo de agitação, como pode ser observado nos trabalhos de Gilkes \& Hughes (1994) que empregaram 20 minutos e de Fieldes \& Perrott (1966) e Camps Arbestain et al. (1999) que agitaram as suspensões por apenas dois minutos. Desse modo, mais pesquisas devem ser realizadas no sentido de se estabelecer um método padronizado que vise a otimizar tanto o rendimento analítico dessa determinação quanto, como já destacado anteriormente, sua utilização como um indicador do comportamento eletroquímico dos solos das regiões tropicais.

Finalmente, a destacada associação observada entre o parâmetro $\mathrm{n}$ da equação de Freundlich e o pH NaF (Tabela 16, Figura 23) reitera mais uma vez a elevada afinidade dos óxidos de A mal cristalizados pelo ânion sulfato, haja vista a estreita associação existente entre o teor dos referidos óxidos e o pH NaF (Tabela 11). 

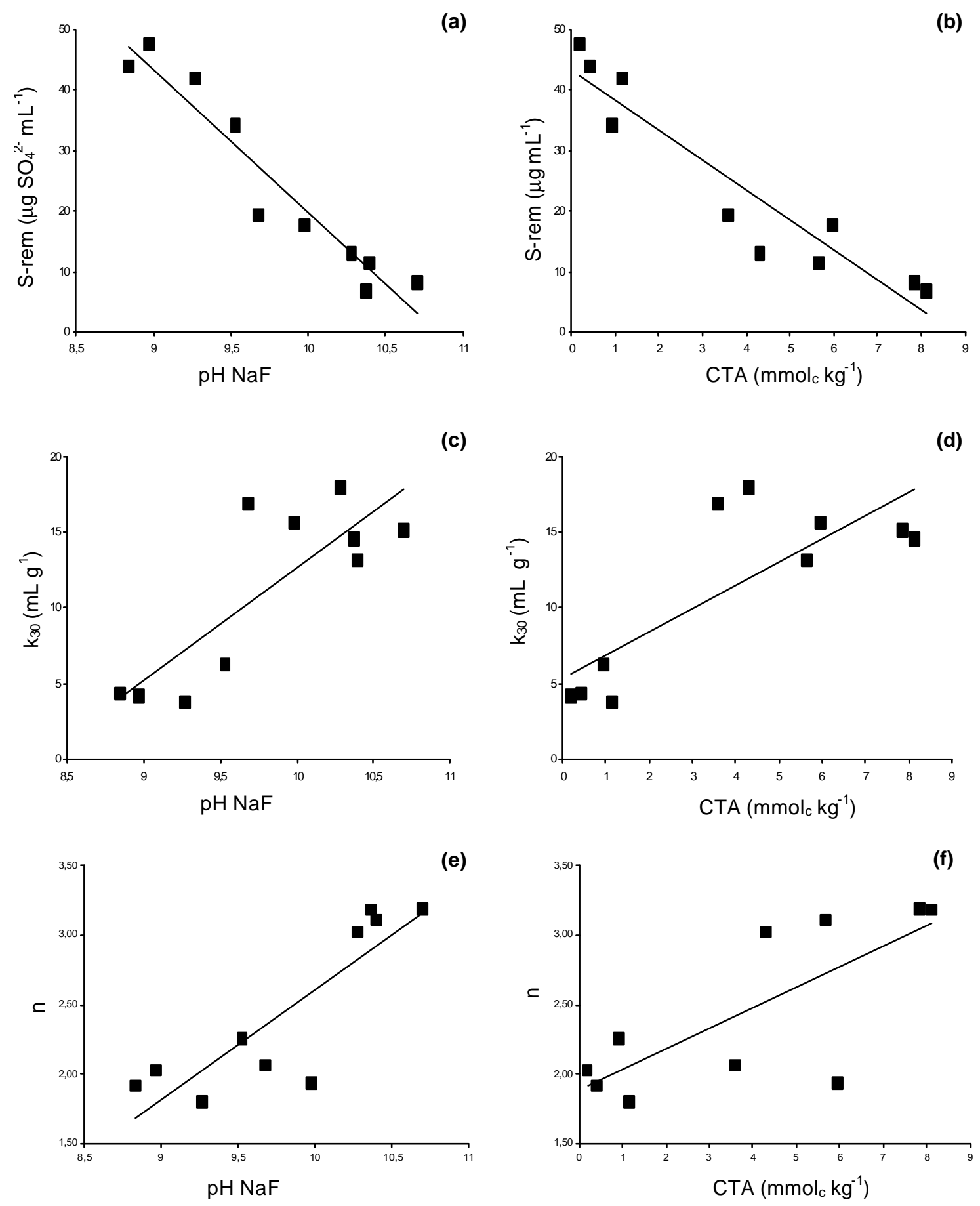

Figura 23 - Relações dos índices de adsorção de sulfato com o pH NaF determinado na TFSA e a CTA. (a) S-rem (TFSA) x pH NaF, (b) S-rem (TFSA) x CTA, (c) $k_{30} \times \mathrm{pH} \mathrm{NaF}$, (d) $k_{30} \times \mathrm{CTA}$, (e) $n$ de Freundlich $\times \mathrm{pH} \mathrm{NaF}$ e (f) $n$ de Freundlich $\times$ CTA. 


\subsubsection{Teores de minerais na fração argila}

No presente trabalho, poucas foram as correlações significativas verificadas entre os índices relacionados àadsorção de sulfato e os teores de minerais semiquantificados na fração argila dos solos estudados. Os coeficientes de correlação obtidos, apresentados na Tabela 17, indicam que os teores de caulinita exerceram influência negativa tanto na capacidade de adsorção de sulfato, estimada pelo sulfato remanescente, quanto na intensidade da interação do ânion com os sítios de adsorção, como estimada pelo parâmetro $n$ de Freundlich. Por outro lado, os teores de óxido de Al mal cristalizados apresentaram relação oposta àobservada para a caulinita frente à adsorção de sulfato. Os teores de gibbsita e hematita também apresentaram relação direta com a afinidade das superfícies adsorvedoras pelos íons $\mathrm{SO}_{4}{ }^{2-}$. As dispersões dos dados referentes às relações do S-rem determinado na TFSA com os teores de minerais e óxidos mal cristalizados são apresentadas na Figura 24, ao passo que na Figura 25 podem ser visualizadas as dispersões dos dados referentes ao parâmetro $n$ de Freundlich e os teores dos referidos componentes inorgânicos da fração argila de alguns dos solos avaliados.

Tabela 17. Coeficientes de correlação linear simples entre o enxofre remanescente (S-rem.) determinado na TFSA, a constante $k_{30}$, o parâmetro $n d a$ equação de Freundlich e os teores dos minerais e óxidos mal cristalizados semiquantificados na fração argila de alguns dos solos estudados $(n=10)$.

\begin{tabular}{lccc}
\hline & S - rem & $k_{30}$ & $\mathrm{n}$ \\
\hline caulinita & $0,90^{* *}$ & $-0,70^{*}$ & $-0,90^{* *}$ \\
gibbsita & $-0,78^{*}$ & $0,54^{\mathrm{ns}}$ & $0,96^{* *}$ \\
hematita & $-0,59^{\mathrm{ns}}$ & $0,51^{\mathrm{ns}}$ & $0,72^{*}$ \\
goethita & $0,14^{\mathrm{ns}}$ & $-0,07^{\mathrm{ns}}$ & $-0,04^{\mathrm{ns}}$ \\
ferrihidrita & $-0,33^{\mathrm{ns}}$ & $0,44^{\mathrm{ns}}$ & $0,30^{\mathrm{ns}}$ \\
Al(OH $)_{3}$ mal cristalizado & $-0,82^{\star *}$ & $0,65^{*}$ & $0,85^{* *}$ \\
\hline
\end{tabular}

**, * significativo a $5 \%$ e a $1 \%$ de probabilidade, respectivamente. ns = não significativo 
(a)
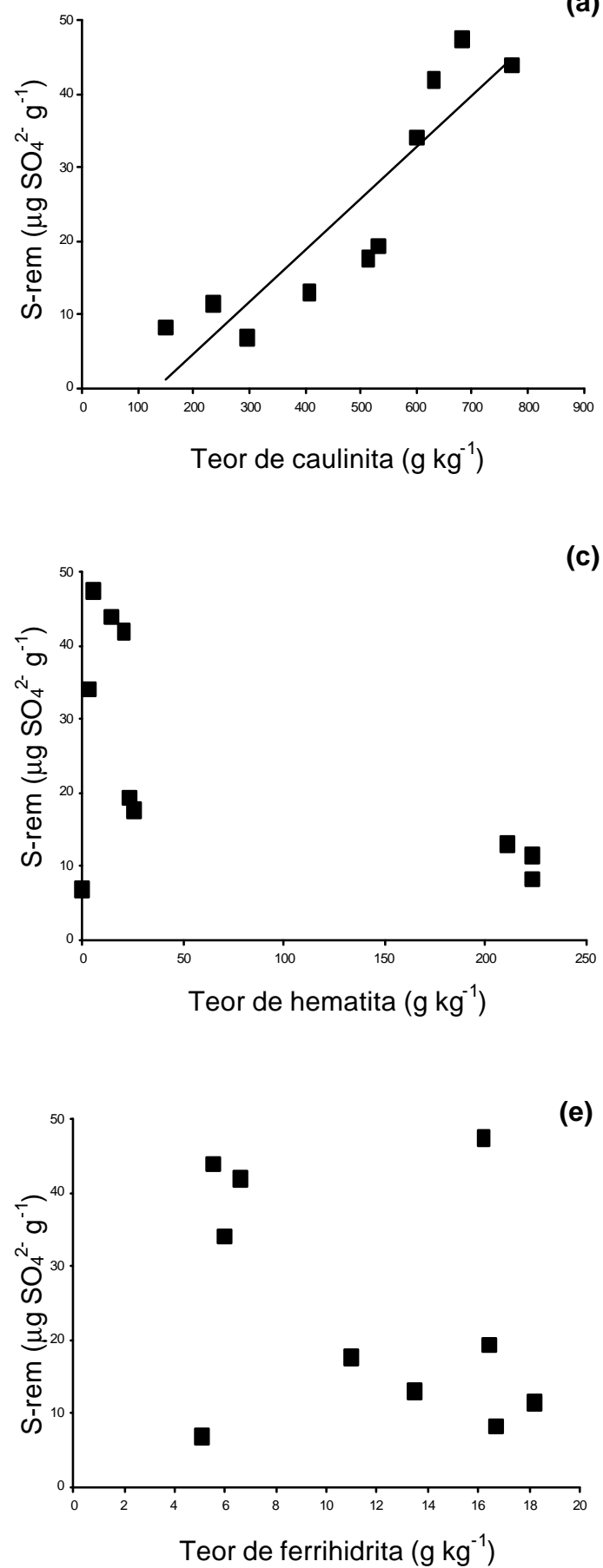

(b)

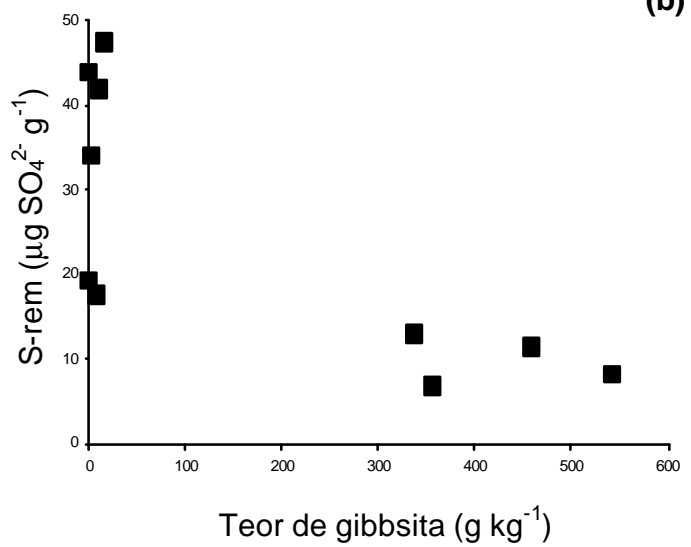

(d)

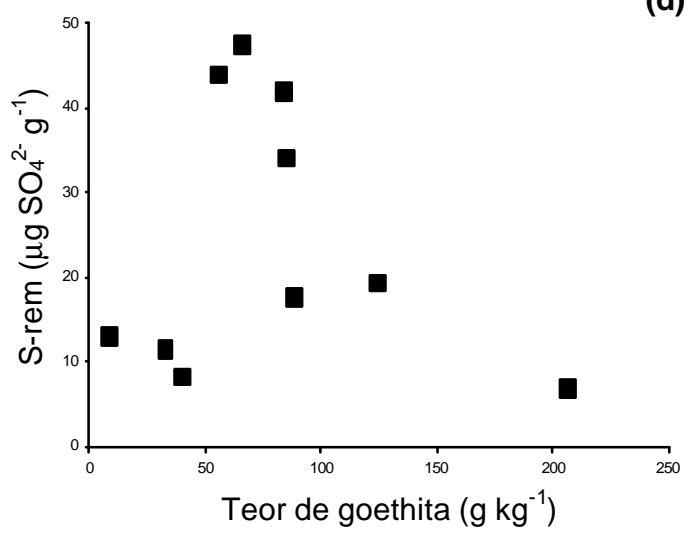

(f)

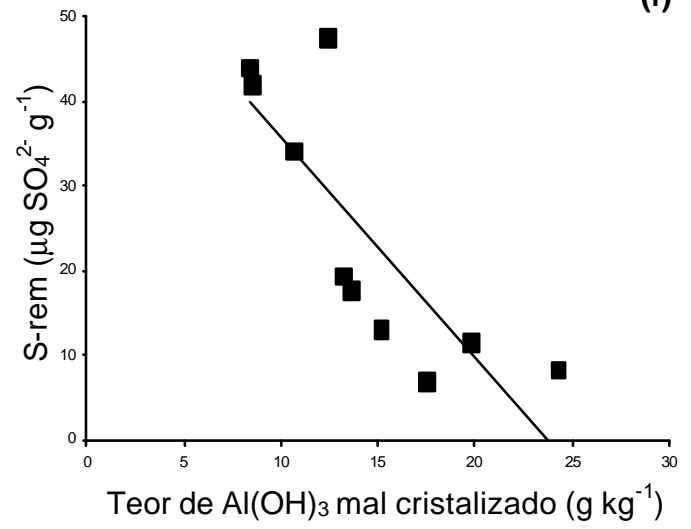

Figura 24 - Relações do S-rem determinado na TFSA e os teores de caulinita (a), gibbsita (b), hematita (c), goethita (d), ferrihidrita (e) e óxidos de alumínio mal cristalizados (f) semiquantificados na fração argila de alguns dos solos estudados $(n=10)$. 
(a)

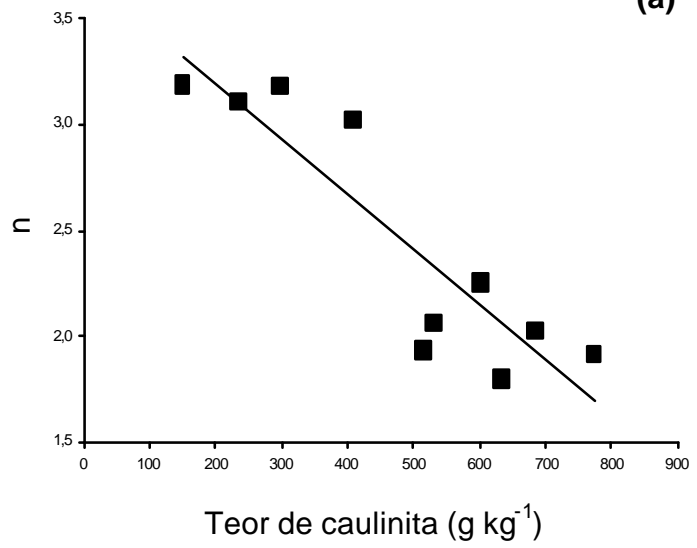

(c)

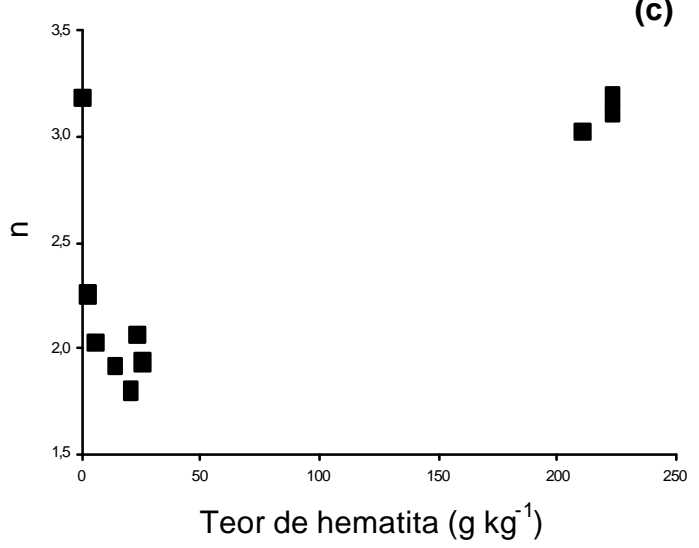

(e)

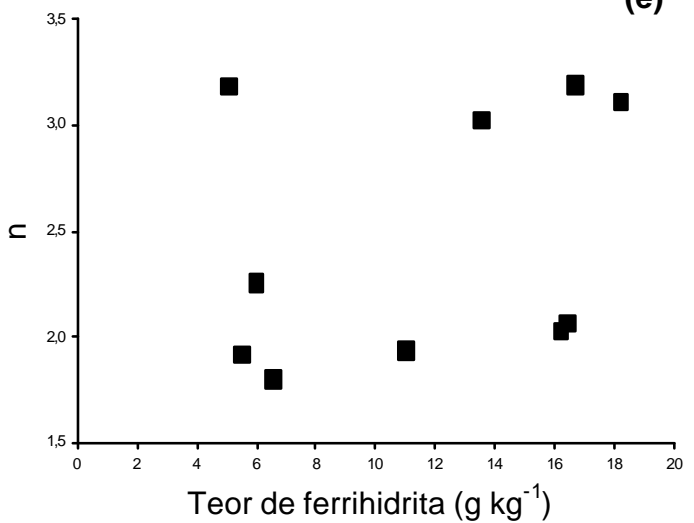

(b)

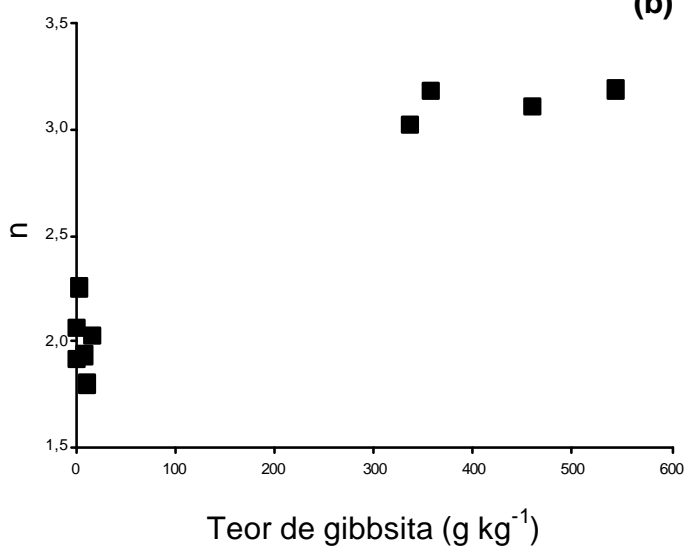

(d)

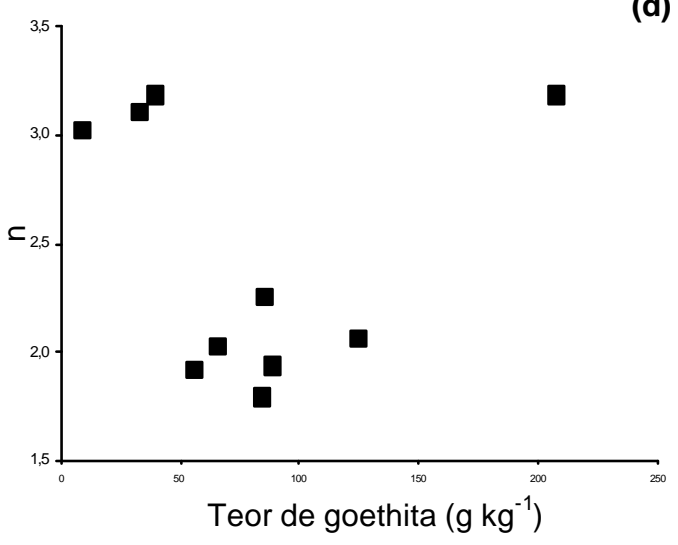

(f)

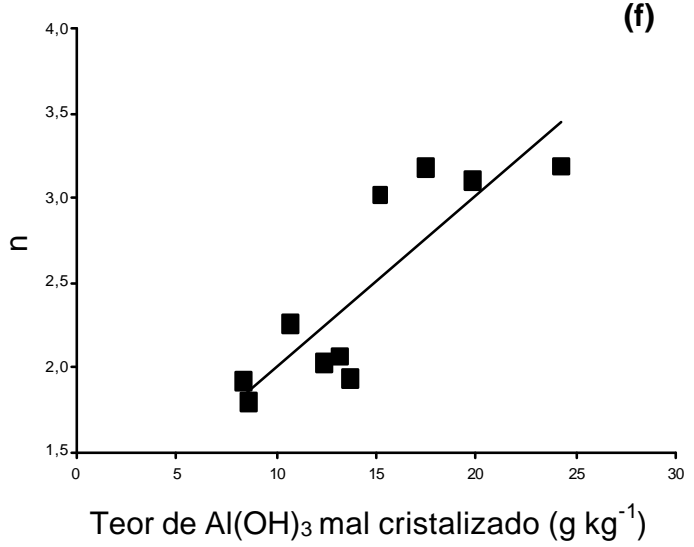

Figura 25 - Relações parâmetro $n$ da equação de Freundlich e os teores de caulinita (a), gibbsita (b), hematita (c), goethita (d), ferrihidrita (e) e óxidos de alumínio mal cristalizados (f) semiquantificados na fração argila de alguns dos solos estudados $(n=10)$. 
Em geral, houve boa concordância entre as magnitudes e significâncias obtidas para os coeficientes de correlação (Tabela 17) e a dispersão dos dados, exceções feitas às relações ob servadas tanto entre os teores de gibbsita e o S-rem quanto entre os teores desse mineral e o parâmetro $\mathrm{n}$ de Freundlich. Tal fato demonstra a importância da visualização de dispersão de dados experimentais ao se efetuar análises de correlação linear simples. No presente caso, embora os valores dos coeficientes referentes às correlações entre o teor de gibbsita e o S -rem e entre o teor de óxidos de Al mal cristalizados e o referido índice de adsorção de sulfato tenham sido similares à análise das dispersões dos dados (Figuras 24b e 24f), pode-se observar que apenas no caso dos óxidos mal cristalizados há coerência entre o coeficiente obtido e a distribuição dos pontos experimentais. A mesma observação pode ser feita ao considerar-se as dispersões apresentadas nas Figuras 25b e 25f, nas quais, novamente, observa-se maior correspondência entre o coeficiente de correlação e a distribuição dos dados para o óxido de Al mal cristalizado.

Assim como verificado para o PESN, CTA e pH NaF, também para a adsorção de sulfato pode-se observar uma relação quantitativa inversa entre os índices de adsorção utilizados e os teores de caulinita das amostras. Tal fato apresenta relação com os tipos de grupos reativos presentes na superfície desse mineral e com os mecanismos envolvidos com a adsorção de sulfato pelo mesmo. Rao \& Sridharan (1984), contrastando dados experimentais de adsorção de sulfato por uma caulinita æ̀ considerações teóricas de Hingston et al. (1972) e Rajan (1978), verificaram excelente concordância com o mecanismo de troca de ligantes proposto pelo último autor. Segundo esse modelo, a adsorção de íons $\mathrm{SO}_{4}{ }^{2-}$ pela caulinita ocorre por meio da troca com grupos $-\mathrm{OH}_{2}{ }^{+}$e $\quad-\mathrm{OH}$ presentes na superfície da mesma, sendo a preferência de troca dependente do grau de saturação de sulfato. Em concentrações mais baixas de sulfato, apenas os grupos $-\mathrm{OH}_{2}{ }^{+}$seriam substituídos por íons sulfato, ao passo que grupos - $\mathrm{OH}$ estariam envolvidos na reação de troca de ligantes em uma condição de maior saturação da superfície pelos íons $\mathrm{SO}_{4}{ }^{2-}$.

Considerando-se a existência de relação direta entre o teor de caulinita e as quantidades de grupos aluminol (-AIOH) e silanol (-SiOH) e que os últimos encontramse normalmente desprotonados e não são passíveis de protonação em condições normais de pH (Schwertmann \& Fechter, 1982; Sparks, 1995; Zhang \& Zhao, 1997), 
pode-se inferir que o aumento na proporção de caulinita em relação aos demais componentes da fase sólida do solo representa uma menor quantidade de sítios de adsorção de sulfato e, portanto, em uma relação inversa entre o teor do mineral e a retenção do referido íon.

Embora a importância dos óxidos de ferro como adsorvedores de sulfato seja amplamente reconhecida (Parfitt \& Smart, 1978; Turner \& Kramer, 1991; Geelhoed et al., 1997; Rietra et al., 1999), não foram encontradas no presente trabalho correlações significativas entre os teores de hematita, goethita e ferrihidrita e a adsorção de sulfato, fato que encontra respaldo nas elevadas dispersões dos dados experimentais (Figuras $24 c, 24 d, 24 e, 25 c, 25 c$ e $25 e)$.

Segundo Cornell \& Schwertmann (1996), considerações cristalográficas indicam que nos óxidos de ferro, os grupamentos hidroxila de superfície podem estar coordenados a um, dois ou três átomos do referido metal. Essas hidroxilas de coordenação simples, dupla ou tripla são por vezes identificadas, respectivamente, como hidroxilas do tipo $A, B$, ou $C$ e apresentam diferentes reatividades. Evidências espectroscópicas demonstram que apenas as hidroxilas de coordenação simples estão envolvidas em reações de troca de ligantes a exemplo do observado para o fosfato (Russel et al., 1974), sulfato (Turner \& Kramer, 1991) e arsenato (Sun \& Doner, 1996).

Considerando-se que a densidade global de grupos $\mathrm{OH}$ de superfície depende da estrutura do cristal e da extensão e desenvolvimento de diferentes faces cristalográficas (Cornell \& Schwertmann, 1996), diferenças de reatividade são esperadas para os diferentes óxidos e mesmo para um mesmo óxido em razão da variabilidade morfológica que seus cristais venham a apresentar. Desse modo, a capacidade adsortiva de um óxido será tanto maior quanto maior o número de faces expostas que apresentem elevada densidade de hidroxilas de coordenação simples (Fontes et al., 2001).

Apesar da falta de evidências, é possível que a falta de uma tendência clara de aumento da capacidade adsortiva de sulfato dos solos avaliados em decorrência do aumento dos seus teores de hematita e goethita seja devida à variabilidade comportamental que esses óxidos apresentem em virtude das diferenças quanto aos materiais de origem e ambientes de formação, à semelhança do observado por Ker et al. (1996) para a adsorção de fosfato em Latossolos brasileiros. 
Estudos de variabilidade comportamental de óxidos de ferro em relação à adsorção de fosfato pela goethita indicam um valor comum de adsorção máxima do referido ânion tanto para goethitas artificiais sintetizadas sob diferentes condições quanto para goethitas pedogenéticas $\left(2,50 \mu \mathrm{mol} P \mathrm{~m}^{2}\right)$ (Torrent et al., 1990; Torrent et al., 1992). Essa coincidência sugere, segundo Torrent et al. (1992), que a adsorção é controlada por um tipo de face cristalina dominante tanto na forma natural quanto na sintética, que apresenta elevada densidade de hidroxilas do tipo A. Estendendo-se essa inferência para a adsorção de sulfato, tal fato indicaria pequena variabilidade comportamental e, portanto, não seria uma causa relevante da falta de relação observada no presente trabalho entre $o$ teor de goethita e a adsorção do referido ânion. Contudo, é possível que diferenças quanto ao grau de cristalinidade da goethita possam também conferir a esse óxido diferentes capacidades de adsorção máxima para um mesmo ânion, assim como verificado por Strauss et al. (1997) para fosfato.

Colombo et al. (1994) consideram que, ao contrário da goethita, as hematitas apresentam maior variabilidade no tocante à forma dos cristais e à presença de faces, tanto em amostras naturais quanto sintéticas. Essas considerações encontram respaldo em observações experimentais como as de Bárron et al. (1988), que verificaram que a capacidade máxima de adsorção de fosfato de um conjunto de 43 hematitas sintéticas, com ampla variação quanto à morfologia, foi de 0,98 $\pm 0,69$ $\mu \mathrm{mol} \mathrm{P} \mathrm{m} \mathrm{m}^{-2}$ e as de Colombo et al. (1994) que observaram uma capacidade de sorção de fosfato média de 1,03 $\pm 0,53 \mu \mathrm{mol} P \mathrm{~m}^{-2}$ em um conjunto de hematitas com diferentes graus de substituição de Fe por Al. É possível que essas observações sejam similares ao se considerar a adsorção de sulfato pela hematita e, portanto, podem oferecer suporte æ̀ observações experimentais do presente trabalho.

Embora a adsorção de ânions orgânicos por óxidos de ferro seja capaz de diminuir a capacidade desses adsorventes de reterem o íon $\mathrm{SO}_{4}{ }^{2-}$ (Inskeep, 1989; Ali \& Dzombak, 1995; Martinez et al., 1998; Liu et al., 1999), acredita-se que esse fenômeno não seja o responsável pela não observação de relações entre os teores de hematita e goethita e a adsorção de sulfato, haja vista as significativas correlações obtidas entre os índices da referida adsorção e os teores de Fe obtidos por diferentes métodos de dissolução (Tabela 15). 
As informações em relação à morfologia de gibbsitas pedogenéticas não são muitas. Segundo Sweegers et al. (1999), as gibbsitas naturais apresentam-se normalmente sob a forma de placas pseudohexagonais, com face basal (001) e faces laterais representadas pelos planos (100) e (110); além do formato supracitado, os referidos autores mencionam também a ocorrência de cristais prismáticos e de agregados lamelares de gibbsita. Mesquita Filho \& Torrent (1983) relataram a presença de cristais de gibbsita de morfologia subarredondada e com diâmetro médio de $75 \mathrm{~nm}$ em solos brasileiros. Netto (1996) encontrou, em diversos solos brasileiros, cristais de gibbsita provavelmente de morfologia prismática.

Embora a gibbsita, assim como os óxidos de ferro, exerça considerável influência sobre os fenômenos de sorção e dessorção aniônicas (Ker, 1995), informações relativas à variabilidade comportamental que esse mineral possa apresentar em relação aos referidos fenômenos são praticamente inexistentes.

As correlações observadas entre os índices de adsorção de sulfato e os teores de óxidos de alumínio mal cristalizados reiteram a importância desses componentes que, mesmo se apresentando em quantidades muito pequenas em relação aos demais, contribuem sobremaneira para as magnitudes de atributos eletroquímicos bem como para a capacidade de adsorção aniônica de solos das regiões tropicais. Os dados obtidos no presente trabalho sugerem ainda que a atividade desses compostos nos solos estudados é diretamente relacionada com a quantidade com que os mesmos se apresentam nesses sistemas, sugerindo, portanto, uma menor variabilidade comportamental para esses materiais.

Possivelmente, por apresentarem um elevado ponto de carga zero, os óxidos de Al mal cristalizados encontram-se em condições normais de $\mathrm{pH}$ com um grande número de grupos $-\mathrm{OH}$ de superfície protonados. Admitindo-se a ocorrência de troca de ligantes, uma maior proporção de grupos $-\mathrm{OH}_{2}{ }^{+}$representaria maior capacidade de adsorção de sulfato, haja vista as considerações de Zhang \& Yu (1997) de que tais grupos são mais facilmente deslocados pelos íons $\mathrm{SO}_{4}{ }^{2-}$ que os grupos $-\mathrm{OH}$ não protonados.

Finalmente, com base no exposto depreende-se a necessidade da realização de pesquisas que permitam uma melhor compreensão da variabilidade comportamental que óxidos de ferro e alumínio possam apresentar em relação ao 
fenômeno de adsorção. Praticamente, toda a pesquisa já realizada nessa área esteve envolvida com a adsorção de fosfato por óxidos de ferro. Assim, torna-se necessário que esses estudos seja ampliados para outros íons de interesse agrícola e ambiental. A inexistência de informações acerca da variabilidade comportamental da gibbsita frente ao fenômeno de adsorção também abre caminho para novos estudos, que podem oferecer informações com elevado grau de detalhe haja vista o advento e possibilidades de aplicação dos métodos microscópicos e espectroscópicos de análise, bem como de procedimentos de refinamento de estruturas cristalinas a exemplo do método de Rietveld.

\subsection{Dessorção de sulfato}

\subsubsection{Quantidades dessorvidas}

Relativamente escassas são as informações relativas à influência direta de minerais pedogenéticos sobre a dessorção de sulfato. As informações disponíveis foram em grande parte obtidas com óxidos sintéticos (Aylmore et al., 1967; Turner \& Kramer, 1992). Além disso, os métodos empregados pelos pesquisadores variam em função da composição e concentração do extrator que varia desde água (Bornemiza \& Llanos, 1967) até soluções salinas concentradas como a de $\mathrm{KCl}_{1} \mathrm{~mol} \mathrm{~L}^{-1}$ (Agbenin, 1997). No presente trabalho, optou-se pela utilização da solução de $\mathrm{CaCl}_{2} 0,01 \mathrm{~mol} \mathrm{~L}^{-1}$ visando-se possibilitar a ocorrência da dessorção em condições mais similares æ̀s observadas nos solos.

A recuperação do sulfato adsorvido pelas amostras variou de $4,8 \%$ para 0 Latossolo Amarelo Ácrico a 28,4\% para o Nitossolo Vermelho Eutroférrico, com um valor médio de $12,4 \%$ para o conjunto de amostras avaliadas. A amostra 14 novamente não foi considerada nessa etapa do trabalho em virtude do comportamento peculiar por ela apresentado em relação àadsorção de sulfato.

Os resultados experimentais foram analisados estatisticamente com a aplicação do teste $\mathrm{F}$ àanális e de variância dos mesmos, seguida da aplicação do teste de comparações múltiplas de Tukey visando-se à identificação da(s) amostra(s) mais 
dessortivas. Em seguida, os percentuais dessorvidos foram correlacionados com atributos das amostras estudadas com o objetivo de se identificar quais deles apresentam relação com o fenômeno de dessorção. Na Figura 26 são apresentados os percentuais de dessorção verificados para as amostras estudadas.

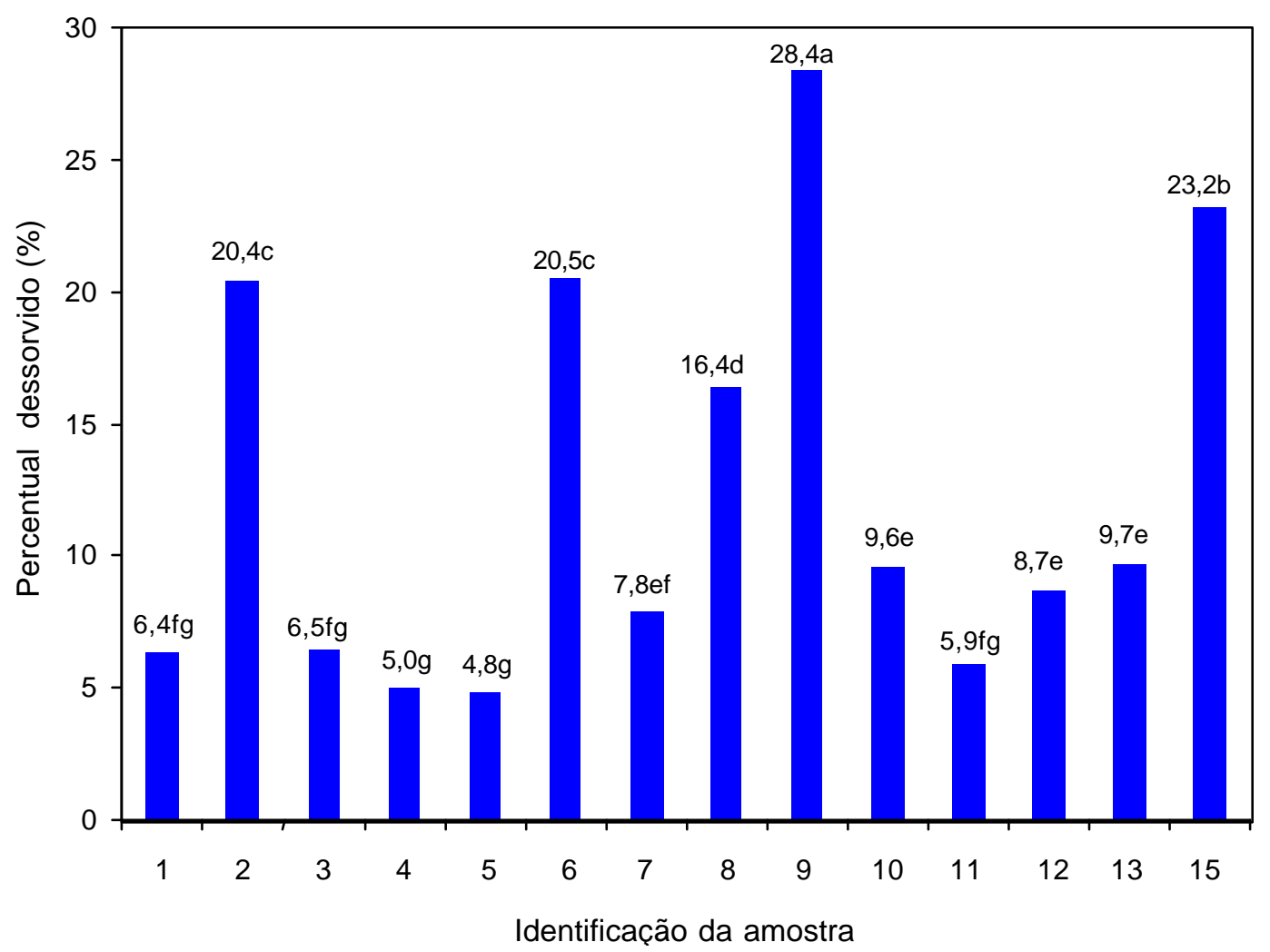

Figura 26 - Percentuais dessorvidos de sulfato nas amostras estudadas. Valores seguidos por uma mesma letra não diferem entre si à $1 \%$ de probabilidade pelo teste de Tukey ( $\mathrm{DMS}=2,21 \%, \mathrm{CV}=5 \%$ ).

A análise da Figura 26 demonstra que os Latossolos Vermelho Acriférrico (amostra 4) e o Amarelo Ácrico (amostra 5) apresentaram os menores percentuais de dessorção, fato intimamente ligado à composição predominantemente oxídica de suas frações argila. Pode-se notar também que a dessorção de sulfato foi influenciada 
pelas quantidades iniciais do íon presentes nas amostras. Tal fato é reforçado pela existência de uma relação direta entre o percentual dessorvido e o teor original de sulfato nas amostras, como pode ser observado nas dispersões dos referidos dados (Figura 27). É importante salientar que o método empregado para o estudo da dessorção permitiu que se descontasse dos teores dessorvidos as contribuições das frações relativas ao sulfato que já se encontrava adsorvido æ̀s amostras (Tabela 3), sendo portanto os resultados expressos em relação æ̀s quantidades de sulfato adsorvidas pelas amostras após a adição do referido íon æ̀s mesmas.

O Argissolo Vermelho Distrófico (amostra 13) foi, dentre os solos estudados, aquele que apresentou o maior teor original de sulfato (137 $\mathrm{mg} \mathrm{S} \mathrm{dm}^{-3}$ ) e também o solo que mais se distanciou da relação observada entre a dessorção de sulfato e o teor original do íon (Figura 27a). A exclusão desse solo da análise de correlação linear simples entre as variáveis supracitadas fez com que o valor do coeficiente de correlação passasse de $0,60^{*}$ para $0,82^{* *}$. Acredita-se que nessa amostra o baixo valor
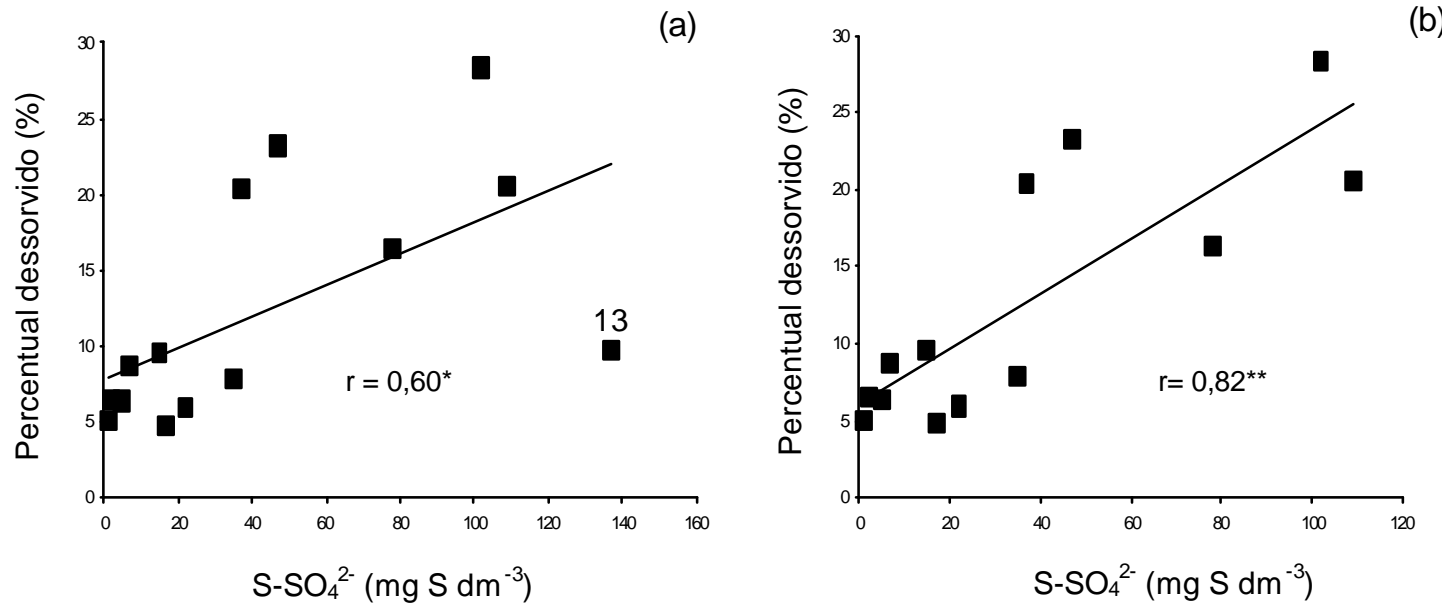

Figura 27 - Relação entres os teores iniciais de sulfato das amostras e os percentuais de dessorção desse íon considerando a presença do solo 13 (a) e sua ausência (b) no cálculo do coeficiente de correlação. 
de $\mathrm{pH}\left(\mathrm{pH} \mathrm{CaCl}_{2}=3,8\right)$ seja o responsável por uma retenção mais intensa do íon sulfato, o que acaba por restringir sua dessorção.

Não é possível afirmar que a presença de sulfato previamente adsorvido tenha sido a causa do comportamento apresentado pela amostra 11 em relação àdessorção. Essa amostra apresenta um dos menores teores de argila dentre o conjunto de solos avaliados (Tabela 2) que é, basicamente, constituída por caulinita (Tabela 5) o que lhe confere baixa capacidade de adsorção e um significativo potencial de dessorção, haja vista a virtual ausência de histerese entre as curvas de adsorção e dessorção de sulfato por caulinitas verificada por Aylmore et al. (1967).

\subsubsection{Relação da dessorção com atributos dos solos}

A análise das Figuras 26 e 27 permite verificar que os maiores percentuais de dessorção de sulfato estiveram associados àmaiores teores originais desse íon nas amostras estudadas. Esse fato resulta em um grande número de coeficientes de correlação não significativos entre o percentual dessorvido de sulfato e atributos das amostras avaliados Por essa razão, o estudo dos relacionamentos entre o percentual dessorvido e atributos dos solos foram realizados excluindo-se das análises as amostras 2, 6, 8, 9 e 15. Contudo, mesmo com essa decisão, poucas foram as associações significativas encontradas entre o percentual de sulfato dessorvido e atributos físicos, mineralógicos e eletroquímicos das amostras consideradas. Na Figura 28 são apresentados os diagramas de dispersão envolvendo a dessorção de sulfato pelas amostras e atributos das mesmas que apresentaram significativa associação com o fenômeno.

A dessorção de sulfato, nos solos considerados diminui àmedida que o grau de intemperismo dos mesmos aumenta, fato que se reflete no valor de coeficiente de correlação entre o percentual dessorvido e o índice Ki $\left(r=0,72^{*}\right)$. Tal associação reitera a importância dos óxidos na retenção desse íon (Bornemiza \& Llanos, 1967; Couto et al., 1979) ao mesmo tempo que indica o maior potencial de lixiviação de sulfato em solos menos intemperizados. 
(a)

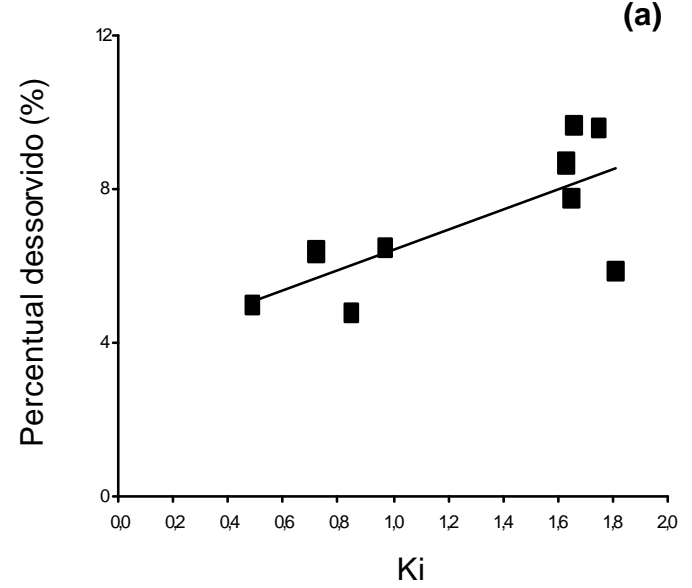

(c)

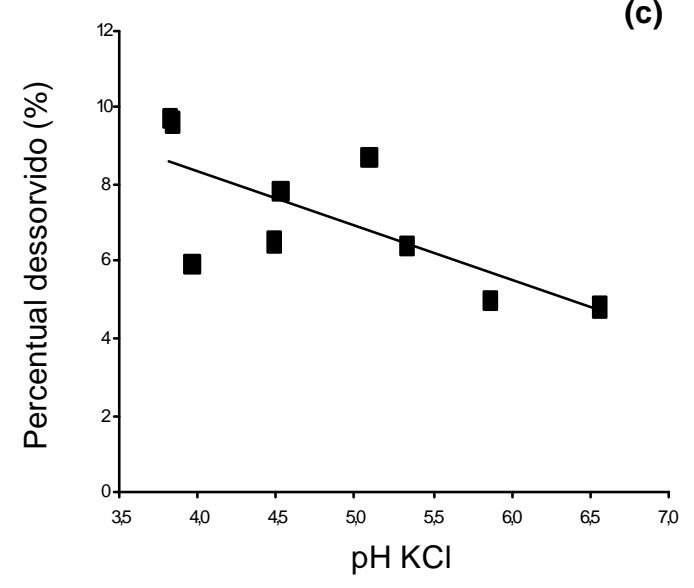

(e)

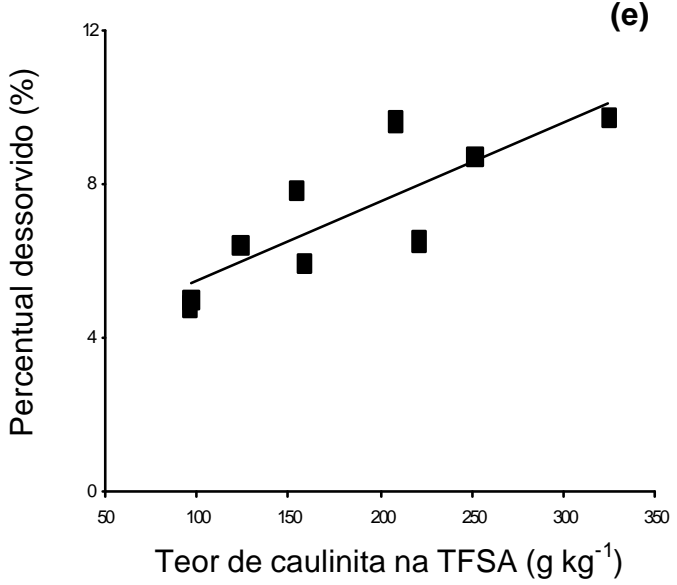

(b)

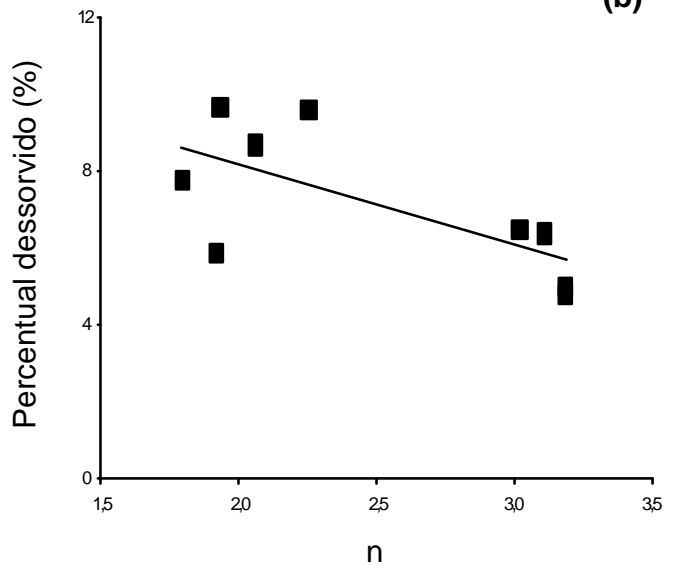

(d)

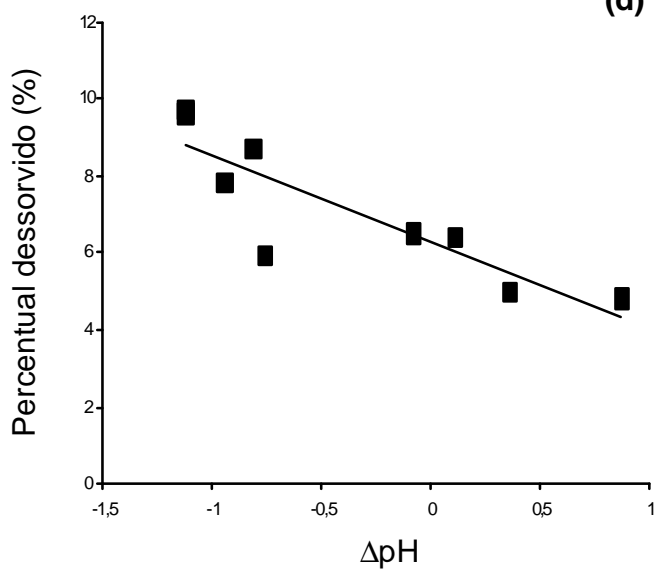

(f)

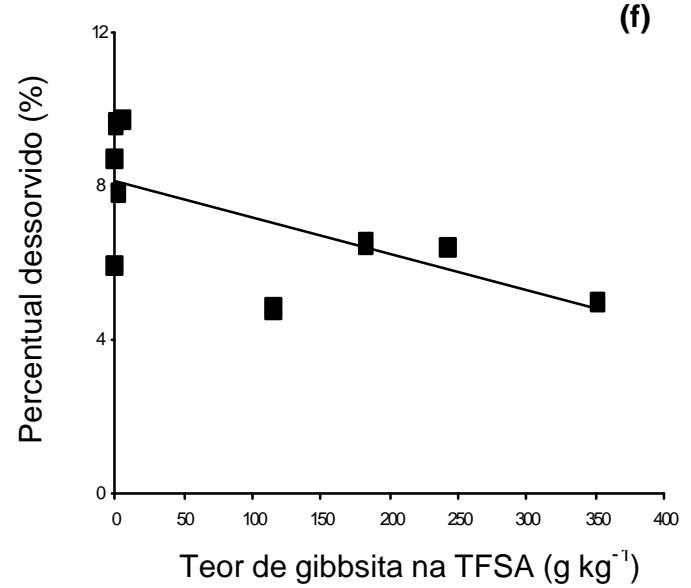

Figura 28 - Relações do percentual de sulfato dessorvido com o índice Ki (a), parâmetro $\mathrm{n}$ da equação de Freundlich (b), $\mathrm{pH} \mathrm{KCl} \mathrm{(c),} \Delta \mathrm{pH}$ (d), teores de caulinita (e) e gibbsita (f) corrigidos para a TFSA $(n=9)$. 
A afinidade da fase sólida pelo íon sulfato, estimada pelo parâmetro $\mathrm{n}$ da equação de Freundlich, apresentou-se negativamente correlacionada com o percentual dessorvido $\left(r=-0,69^{*}\right)$. Assim como esse parâmetro, o $\mathrm{pH} \mathrm{KCl} \mathrm{e} \mathrm{o} \Delta \mathrm{pH}$ apresentaramse positivamente correlacionados com os teores de gibbsita e de óxido de Al mal cristalizados e, como já destacado para o pH $\mathrm{KCl}$ em tópico anterior, negativamente relacionados com o teor de caulinita na fração argila fato que explica as correlações inversas também observadas para esses atributos com o percentual dessorvido $\left(\mathrm{pH} \mathrm{KCl}: \mathrm{r}=-0,70^{*} ; \Delta \mathrm{pH}=-0,86^{\star *}\right)$.

Finalmente, e de maneira inversa ao observado nos estudos de adsorção, obteve-se associação direta entre os teores de caulinita corrigidos para a TFSA e o percentual dessorvido $\left(r=0,83^{\star *}\right)$ ao passo que o efeito restritivo da gibbsita, cujos teores também foram corrigidos para a TFSA, sobre a dessorção foi caracterizado pela correlação inversa observada entre seus teores e o índice de dessorção utilizado $\left(r=-0,67^{*}\right)$.

De forma geral, poucas foram as correlações destacáveis entre a dessorção de sulfato e os atributos dos solos. Essa constatação concorda com a dificuldade do estabelecimento desse tipo de associação, como cestacado por Ballaux \& Peasle (1975) e Raven \& Hossner (1993). Contudo, mesmo considerando-se as dificuldades e limitações inerentes a esse tipo de estudo, as relações observadas no presente trabalho reiteram a maior adequação dos solos mais intemperizados à prática da gessagem, haja vista a importância da retenção de sulfato em camadas subsuperficiais de modo a minimizar a lixiviação de nutrientes catiônicos.

Alguns resultados do presente trabalho permitem o questionamento da abrangência do método de recomendação de doses de gesso baseado no teor de argila do solo, conforme proposto por Raij et al. (1996). Segundo esse critério, a quantidade de gesso a ser aplicada, em kg ha-1, corresponde a seis vezes o teor de argila, expresso em $\mathrm{g} \mathrm{kg}^{-1}$. Ao considerar-se o Latossolo Vermelho Distrófico (amostra 6) e o Nitossolo Vermelho Eutroférrico (amostra 9), classificados como muito argiloso e argiloso, respectivamente, verifica-se que tais solos receberiam elevadas doses de gesso. Contudo, a expressiva presença de caulinita na fração argila desses solos pode favorecer a lixiviação de sulfato nos mesmos. Assim, é desejável que outros critérios sejam estudados com o objetivo de refinar o método de recomendação 
de gesso para os solos agrícolas das regiões tropicais. Para o Nitossolo Vermelho Eutroférrico por exemplo, o $\mathrm{pH} \mathrm{NaF}$ avaliado na TFSA poderia se constituir em um indicativo de sua menor capacidade de adsorção de sulfato, quando comparada æ̀ dos solos mais intemperizados, e, desse modo, auxiliar na recomendação de aplicações de doses mais adequadas de gesso. Contudo, mais trabalhos nessa linha de pesquisa se fazem necessários. 


\section{CONCLUSÕES}

Os materiais, métodos e condições experimentais utilizados no presente trabalho permitem as seguintes conclusões:

- O método analítico computacional, desenvolvido para o tratamento de dados de titulação potenciométrica, apresentou-se adequado para a determinação rápida e não subjetiva do valor do PESN de amostras de solo .

- A utilização do programa computacional possibilita uma melhor avaliação da precisão do valor obtido para o PESN.

- Os valores de pH medidos em suspensões de solo e solução de $\mathrm{KCl} 1 \mathrm{~mol} \mathrm{~L}^{-1}$ são bons estimadores do PESN para solos com baixos teores de alumínio trocável.

- Há necessidade de reavaliação dos métodos de determinação da capacidade de troca catiônica efetiva dos solos com caráter ácrico.

- Há significativa presença de cargas negativas de caráter permanente em solos do Estado de São Paulo, mesmo naqueles mais intemperizados.

- Há a necessidade de mais estudos relacionados ao método da adsorção de césio para a avaliação de cargas variáveis e permanentes em solos das regiões tropicais. 
- Há dificuldade em se utilizar o método das isotermas para avaliação da capacidade de adsorção de sulfato em solos que já apresentam consideráveis teores adsorvidos desse íon, àexceção dos solos mais ácidos.

- A composição mineralógica da fração argila é muito mais importante que a classe granulométrica a que o solo pertence na definição de capacidade do mesmo em adsorver sulfato.

- Os teores de óxidos de alumínio, em especial dos mal cristalizados, apresentam destacável relação direta com o PESN, CTA e capacidade de adsorção de sulfato dos solos avaliados.

- A presença de elevadas quantidades de caulinita nos solos contribuem para que os mesmos apresentem menores PESN, CTA e capacidade de adsorção de sulfato dos solos avaliados.

- A dessorção de sulfato apresenta dependência do grau de saturação desse íon na fase sólida.

- Teores elevados de caulinita favorecem a dessorção de sulfato, ao contrário do observado para a gibbsita e óxidos de alumínio mal cristalizados.

- Os valores de pH determinados em suspensões de solo e solução de $\mathrm{NaF} 1 \mathrm{~mol} \mathrm{~L}^{-1}$ são bons indicadores da capacidade de adsorção aniônica das camadas subsuperficiais dos solos intemperizados das regiões tropicais.

- É recomendável a intensificação das pesquisas visando tanto a uma melhor compreensão dos mecanismos envolvidos com as reações da solução de $\mathrm{NaF}$ e a fase sólida do solo como para o desenvolvimento metodológico com vistas a uma mais eficiente determinação desse atributo.

- É recomendável a inclusão do $\mathrm{pH} \mathrm{NaF}$ dentre as avaliações realizadas nos trabalhos de levantamento e classificação de solos. 
- É necessária a intensificação das pesquisas relacionando a manifestação de propriedades eletroquímicas, a capacidade adsortiva e de restrição à dessorção com propriedades intrínsecas de óxidos como a hematita, a goethita e a gibbsita.

- As aplicações de gesso agrícola devem ser mais criteriosas em solos que apresentam camadas subsuperficiais cauliníticas.

- Recomendações de gessagem efetuadas apenas com base no teor de argila podem, em alguns casos, não ser adequadas e resultarem em significativa movimentação de sulfato e cátions trocáveis no perfil do solo. 


\section{REFERÊNCIAS BIBLIOGRÁFICAS}

ABRAHÃO, W.A.P.; COSTA, L.M.; NEVES, J.C.L. Comparação entre métodos de determinação de PCZ em solos de baixa CTC. In: CONGRESSO BRASILEIRO DE CIÊNCIA DO SOLO, 25., Viçosa, 1995. Resumos expandidos. Viçosa: SBCS, UFV, 1995. p.283- 285.

AGBENIN, J.O. Sulfate retention by kaolinitc alfisols from Nigerian savanna. Soil Science Society of America Journal, v.61, n.1, p. 53-67, 1997.

ALEWELL, C.; BREDEMEIER, M.; MATZER, E.; BLANCK, K. Soil solution response to experimentally reduced acid deposition in a forest ecosystem. Journal of Environmental Quality, v.26, n.3, p. $658-665,1997$.

ALI, M.A.; DZOMBAK, D.A. Competitive sorption on simple organic acids and sulfate on goethite. Environmental Science and Technology, v. 30, n.4, p. 1061 $1071,1996$.

ALLEN, B.L.; HAJEK, B.F. Mineral occurrence in soil environments. In: DIXON, J.B. and WEED, S.B. (Ed.). Minerals in soil environments. Madison : Soil Science Society of America, 1989. cap. 5, p.199-278.

ALLEONI, L.R.F. Atributos eletroquímicos de solos ácricos do norte paulista. Piracicaba, 1992. 121p. Dissertação (Mestrado) - Escola Superior de Agricultura "Luiz de Queiroz", Universidade de São Paulo.

ALLEONI, L.R.F. Adsorção de boro em Podzólico e Latossolos paulistas. Piracicaba, 1996. 127p. Tese (Doutorado) - Escola Superior de Agricultura "Luiz de Queiroz", Universidade de São Paulo. 
ALLEONI, L.R.F.; CAMARGO, O.A. Ponto de efeito salino nulo: proposição de nomenclatura. Boletim Informativo da Sociedade Brasileira de Ciência do Solo, v.18, n.1, p.5 - 11, 1993.

ALLEONI, L.R.F.; CAMARGO, O.A. Solos ácricos: atributos e manejo. Boletim Informativo da Sociedade Brasileira de Ciência do Solo, v.20, n.1, p. 9 - 17, 1995.

ALVA, A.K; GASCHO, G.J. Differential leaching of cations and sulfate in gypsum amended soils. Communications in Soil Science and Plant Analysis, v. 22, $\mathrm{n}$. 11 - 12, p. 1195 - 1206, 1991.

ALVARADO, A.; BUOL, S.W. Field estimation of phosphate retention by Andepts. Soil Science Society of America Journal, v.49, n.4 , p . 911-914, 1985.

ALVAREZ V, V.H.; NOVAIS, R.F.; DIAS, L.E.; OLIVEIRA, J. A. Determinação e uso do fósforo remanescente. Boletim Informativo da Sociedade Brasileira de Ciência do Solo, v.25, n.1, p.24-32, 2000.

ALVAREZ V, V.H.; NOVAIS, R.F.; NEVES, J.C.L.; BARROS, N.F. Níveis críticos de enxofre em solos de cerrado para crescimento de mudas de eucalipto. In: CONGRESSO BRASILEIRO DE CIÊNCIA DO SOLO, 19., Curitiba, 1983. Resumos. Curitiba: SBCS, 1983. p. $164-165$.

ALVAREZ V., V.H.; FONSECA, D.M. Definição de doses de fósforo para determinação da capacidade máxima de adsorção de fosfatos e para ensaios em casa de vegetação. Revista Brasileira de Ciência do Solo, v.14, n.1, p. 49 - 55, 1990.

AMARASIRIWARDENA, D.D.; BOWEN, L.H.; WEED, S.B. Characterization and quantification of aluminum-substituted hematite-goethite mixtures by X-ray diffraction and infrared and Mössbauer spectroscopy. Soil Science Society of America Journal, v. 52, n.4 , p. $1179-1186,1988$.

ANDERSON, S.J.; SPOSITO, G. Cesium adsorption method for measuring accessible structural surface charge. Soil Science Society of America Journal, v.55, n.6, p. 1569 - 1576, 1991.

AYLMORE, L.A.G.; MESBAHUL, K.; QUIRK, J.P. Adsorption and desorption of sulfate ion by soil constituents. Soil Science, v. 103, n. 1, p. $10-15,1967$. 
BALLAUX, J.C.; PEASLEE, D.E. Relationships between sorption and desorption of phosphorus by soils. Soil Science Society of America Journal, v. 39, n.2, p. $275-278,1975$.

BARRÓN, V.; HERRUZO, M.; TORRENT, J. Phosphate adsorption by aluminous hematites of different shapes. Soil Science Society of America Journal, v. 52, n.3, p. $647-651,1988$.

BARRÓN, V.; TORRENT, J. Use of Kubelka-Munk theory to study the influence of iron oxides on soil colour. Journal of Soil Science, v. 37, n.4, p. 499-510, 1986.

BARROW, N.J. Effects of adsorption of sulfate by soils on the amount of sulfate present and its availability to plants. Soil Science, v. 108, n. 3, p. $193-201,1969$.

BARROW, N.J. The description of phosphate adsorption curves. Journal of Soil Science, v. 29, n.4, p. $447-462,1978$.

BARROW, N.J. A mechanistic model for describing the sorption and desorption of phosphate by soil. Journal of Soil Science, v. 34, n. 4, p.733-750, 1983.

BERG, W. A.; THOMAS, G.W. Anion eluation patterns from soils and soil clays. Soil Science Society of America Proceedings, v. 23, n.2, p. 348 - 350, 1959.

BESOAIN, E. Mineralogia de arcillas de suelos. San Jose: IICA, 1985. 1205p.

BHATTI, J.S.; FOSTER, N.W.; EVANS, L.J. Sulphate sorption in relation to properties of podzolic and brunisolic soils in northeastern Ontario. Canadian Journal of Soil Science, v. 77, n.3, p. $397-404,1997$.

BOGNOLA, I. A. Caracterização química, física e mineralógica de solos intermediários entre Latossolos Brunos e Latossolos Roxos. Viçosa, 1995. 205p. Dissertação (Mestrado) - Universidade Federal de Viçosa.

BOHN, H.L.; McNEAL, B.L.; O'CONNOR, G. A. Soil chemistry. New York: John Wiley, 1979. 329p.

BOLAN, N.S.; NAIDU, R.; SYERS, J.K.; TILLMAN, R.W. Surface charge and solute interactions in soils. Advances in Agronomy, v. 67, p. $87-140,1999$.

BOLAN, N.S.; SYERS, J.K.; SUMNER, M.E. Calcium-induced sulfate adsorption by soils. Soil Science Society of America Journal, v. 57, n.3, p. 691-696, 1993. 
BOLAN, N.S.; SYERS, J.K.; TILLMAN, R.W. lonic strenght effects on surface charge and adsorption of phosphate and sulphate by soils. Journal of Soil Science, v.37, n.3, p. $379-388,1986$.

BOLAN, N.S.; SYERS, J.K.; TILLMAN, R.W.; SCOTTER, D.R. Effect of liming and phosphate additions on sulphate leaching in soils. Journal of Soil Science, v.39, n.3, p. 493-504, 1998.

BOLLAND, M.D.A.; GILKES, R.J.; BRENNAN, R.F.; ALLEN, D.G. Comparison of seven phosphorus sorption indices. Australian Journal of Soil Research, v.34, n.1, p.81-89, 1996.

BORNEMISZA, E.; LLANOS, R. Sulfate movement, adsorption and desorption in three Costa Rican soils. Soil Science Society of America Proceedings, v.31, n. 3 p. 356-360, 1967.

BOWER, C.A.; HATCHER, J.J. Adsorption of fluoride by soils and minerals. Soil Science, v. 103, n.2, p.151-154, 1967.

BULENS, M.; DELMON, B. The exothermic reaction of metakaolinite in the presence of mineralizers. Influence of crystallinity. Clays and Clay Minerals, v. 25, n. 4, p. 271-277, 1977.

BUURMAN, P., LAGEN, B van; VELTHORST, E.J. Manual for soil and plant water analysis. Wageningen: Backhuys Publishers Leiden, 1996. 314p.

CAMARGO, M, N.; JACOMINE, P.K.T.; OLMOS, I.L.J.; CARVALHO, A. P. Proposição preliminar e distinção de Podzólicos Vermelho-Escuros. In: EMPRESA BRASILEIRA DE PESQUISA AGROPECUÁRIA. Serviço Nacional de Levantamento e Conservação do Solo. Conceituação sumária de algumas classes de solos recém-reconhecidas nos levantamentos e estudos de correlação do SNLCS. Rio de Janeiro, 1982. p. 7 - 20 (Circular Técnica, 1).

CAMARGO, O. A.; JACOMINE, P.K.T.; CARVALHO, A.P.; J. OLMOS, I.L. The Brazilian classification of Latosols. In: INTERNATIONAL SOIL CLASSIFICATION WORKSHOP: CLASSIFICATION, CHARACTERIZATION AND UTILIZATION OF OXISOLS, 8., Rio de Janeiro, 1986. Proceedings. Rio de Janeiro: EMBRAPA, SMSSM, AID, UPR, 1988. p. $190-199$.

CAMPS ARBESTAIN, M.; BARREAL, M.E.; MACÍAS, F. Parent material influence on sulfate sorption in forest soils from northwestern Spain. Soil Science Society of America Journal, v. 63, n.6, p. $1906-1914,1999$. 
CANTARELLA, H.; PROCHNOW, L.I. Determinação de sulfato em solos. In RAIJ, B. van; ANDRADE, J.C. de; CANTARELLA, H.; QUAGGIO, J.A. (Ed.) Análise química para avaliação da fertilidade de solos tropicais. Campinas: Instituto Agronômico, 2001. cap. 14, p.225 - 230.

CANTARELLA, H.; QUAGGIO, J.A.; RAIJ, B. van Determinação da matéria orgânica. In RAIJ, B. van; ANDRADE, J.C. de; CANTARELLA, H.; QUAGGIO, J.A. (Ed.) Análise química para avaliação da fertilidade de solos tropicais. Campinas: Instituto Agronômico, 2001. cap. 9, p.173 - 180.

CANTARELLA, H.; RAIJ, B. van; COSCIONE, A.R.; ANDRADE, J.C. Determinação de alumínio, cálcio e magnésio trocáveis em extrato de cloreto de potássio. In RAIJ, B. van; ANDRADE, J.C. de; CANTARELLA, H.; QUAGGIO, J.A. (Ed.) Análise química para avaliação da fertilidade de solos tropicais. Campinas: Instituto Agronômico, 2001. cap. 13, p.213 - 224.

CHAGAS, C.S.; SILVA, M.L.N., SILVA, C.A. Caracterização química e mineralógica de três solos da região de Lavras (MG). In: CONGRESSO BRASILEIRO DE CIÊNCIA DO SOLO, 24., Goiânia, 1993. Anais. Goiânia: SBCS, 1993. v.1, p. 231 - 232.

CHAO, T.T.; HARWARD, M.E.; FANG, S.C. Movements of $S^{35}$ tagged sulfate ions. Soil Science Society of America Proceedings, v. 26, n.1, p. $27-32,1962$.

CHARLET, L.; SPOSITO, G. Bivalent ion adsorption by an Oxisol. Soil Science Society of America Journal, v. 53, n.3, p. 691 - 695, 1989.

CHARLET, L.; DISE, N.; STUMM, W. Sulfate adsorption on a variable charge soil and on reference minerals. Agriculture, Ecosystems \& Environment, v.47, n.2, p. 87- 102, 1993.

CHEN, Z.; XING, B.; McGILL, W.B. A unified sorption variable for environmental applications of the Freundlich equation. Journal of Environmental Quality, v.28, n.5 , p.1422 - 1428, 1999.

CHESNIN, L.; YIEN, C.H. Turbidimetric determination of available sulfates. Soil Science Society of America Proceedings, v.15, n.1, p.149 - 151, 1950.

CHITTLEBOROUGH, D.J.; WALKER, P.H. Crystallinity of soil kaolinites in relation to clay particle-size and soil age. Journal of Soil Science, v. 39, n. 1, p. 81 - 86, 1988. 
CHOROM, M.; RENGAASMY, P.; MURRAY, R.S. Clay dispersion as influenced by pH and net particle charge of sodic soils. Australian Journal of Soil Research, v. 32, n.6, p. $1243-1252,1994$.

CHOROVER, J.; SPOSITO, G. Surface charge characteristics of kaolinitic tropical soils. Geochimica et Cosmochimica Acta, v.59, n.5, p. 875 - 884, 1995.

CHOROVER, J.; DICHIARO, M.J.; CHADWICK, A. Structural and cesium retention in a chronosequence of tephritic soils. Soil Science Society of America, v.63, n.1, p.169-177, 1999.

COLOMBO, C.; BARRÓN, V.; TORRENT, J. Phosphate adsorption and desorption in relation to morphology and crystal properties of synthetic hematites. Geochimica et Cosmochimica Acta, v. 58, n. 4, p. 1261 - 1269, 1994.

COMFORT, S.D.; DICK, R.P.; BAHAM, J. Modeling soil sulfate sorption characteristics. Journal of Environmental Quality, v.21, n.3, p. 426 - 432, 1992.

COMFORT, S.D.; SHEA, P.J.; HUNDAL, L.S.; LI, Z.; WOODBURY, B.L.; MARTIN, J.L.; POWERS, W.L. TNT transport and fate in contaminated soil. Journal of Environmental Quality, v.24, n.6, p. 1174 - 1182, 1995.

CORNELL, R.M.; SCHWERTMANN, U. The iron oxides: structure, properties, reactions occurrence and uses. Weinheim : VCH, 1996. 573p.

COSTA, L.M.; MORAIS, E.J.; RIBEIRO, A.C.; FONSECA, S. Cargas elétricas de um Latossolo Vermelho-Amarelo com diferentes coberturas florestais. Revista Ceres, v.31, n.177, p.351-359, 1984.

COURCHESNE, F.; LABERGE J.F.; DUFRESNE, A. Influence of soil organic matter on sulfate retention in two Podzols in Quebec, Canada. Canadian Journal of Soil Science, v.79, n.1, p. 103-109, 1999.

COURCHESNE, F. Electrolyte concentration and composition effects on sulfate sorption by two Spodosols. Soil Science Society of America Journal, v. 55, n.6, p. $1576-1581,1991$.

COURCHESNE, F.; HENDERSHOT, W.H. Sulfate retention in some podzolic soils of the southern Laurentians, Quebec. Canadian Journal of Soil Science, v. 69, n.2, p. $337-350,1989$. 
COUTO, W.; LATHWELL, D.J.; BOULDIN, D.R. Sulfate adsorption by two oxisols and an alfisol of the tropics. Soil Science, v. 127, n. 3, p. $108-116,1979$.

CURI, N.; CAMARGO, O.A.; GUEDES, G.A.A. Sorção de fósforo em materiais de Latossolos do Brasil Sudeste e Sul In: REUNIÃO DE CLASSIFICAÇÃO E CORRELAÇÃO DE SOLOS E INTERPRETAÇÃO DE APTIDÃO AGRÍCOLA, 3., Rio de Janeiro, 1988. Anais. Rio de Janeiro: EMBRAPA, SNLCS, 1988. p. $267-$ 282.

CURI, N.; FRANZMEIER, D.P. Toposequence of Oxisols from the Central Plateu of Brazil. Soil Science Society of America Journal, v.48, n. 2, p. $341-346,1984$.

CURTIN, D.; SYERS, J.K. Extractability and adsorption of sulphate in soils. Journal of Soil Science, v. 41, n.2, p. $305-312,1990$.

DICK, D.P.; SCHWERTMANN, U. Microaggregates from oxisols and inceptisols: dispersion through selective dissolutions and physicochemical treatments. Georderma, v.74, n. 1/2, p. 49-63, 1996.

DOLUI, A.K.; CHAKRABARTI, C. Sulphate sorption and desorption by some Alfisols. Agrochimica, v. 42, n.5, p.175 - 189, 1998.

DYNIA, J.F. Propriedades eletroquímicas e retenção aniônica de um Latossolo Vermelho-Escuro sob diversas práticas de manejo. Piracicaba, 1993. 122p. Dissertação (Mestrado) - Escola Superior de Agricultura "Luiz de Queiroz", Universidade de São Paulo.

DYNIA, J.F.; CAMARGO, O.A. Adsorção e movimento de sulfato em Latossolo de cerrado submetido a calagem e adubação fosfatada. Revista Brasileira de Ciência do Solo, v. 19, n.2, p. 249 - 253, 1995.

DYNIA, J.F.; CAMARGO, O.A. Effects of liming, green manuring, and phosphate addition on electrochemical attributes of an Oxisol from Central Brazil. Communications in Soil Science and Plant Analysis, v. 29, n. 5/6, p. $755-762$, 1998.

EMPRESA BRASILEIRA DE PESQUISA AGROPECUÁRIA. Centro Nacional de Pesquisas de Solos. Manual de métodos de análise do solo. 2.ed. Rio de Janeiro: Embrapa Solos, 1997. 212p. 
EMPRESA BRASILEIRA DE PESQUISA AGROPECUÁRIA. Centro Nacional de Pesquisas de Solos. Sistema brasileiro de classificação de solos. Rio de Janeiro: Embrapa Solos, 1999. 412p.

ESMINGER, L.E. Some factors affecting the adsorption of sulfate by Alabama soils. Soil Science Society of America Proceedings, v. 18, n.2, p. 259-264, 1954.

FABRIS, J.D.; RESENDE, M.; SILVA, E.G.; COEY, M.D. Iron oxides in two Oxisols from the Brazilian coastal plain. Journal of Soil Science, v.36, n.4, p. $543-550$, 1985.

FIELDES, M.; PERROT, K.W. The nature of allophane in soils: part 3. Rapid field and laboratory test for allophane. New Zealand Journal of Science, v.9, n.3, p. 623 629, 1966.

FONTES, M.P.F. Vermiculita ou esmectita com hidróxi nas entrecamadas: proposição de nomenclatura. Boletim da Sociedade Brasileira de Ciência do Solo, v. 15, n. 1, p. $24-28,1990$.

FONTES, M.P.F. Iron oxide-clay mineral association in Brazilian Oxisols: a magnetic separation study. Clays and Clay Minerals, v.40, n.2, p. 175 - 179, 1992.

FONTES, M.P.F. Comments on "The effects of soil properties on the differential phosphate sorption by semiarid soils from Northeast Brazil". Soil Science, v.159, n.1, p.74-75, 1995.

FONTES, M.P.F.; SPOSITO, G. Medição da densidade de carga estrutural acessível em Latossolos brasileiros com diferentes mineralogias. In: CONGRESSO BRASILEIRO DE CIÊNCIA DO SOLO, 25., Viçosa, 1995. Resumos expandidos. Viçosa: SBCS, UFV, 1995. p.292 - 294.

FONTES, M.P.F.; WEED, S.B. Iron oxides in selected Brazilian Oxisols: I. Mineralogy. Soil Science Society of America Journal, v.55, n.4, p.1143-1149, 1991.

FONTES, M.P.F., WEED, S.B. Phosphate adsorption by clays from Brazilian oxisols: relantionship with specific area and mineralogy. Geoderma, v.72, n.1, p.37 - 51, 1996.

FONTES, M.P.F.; CAMARGO, O.A.; SPOSITO, G. Eletroquímica das partículas coloidais e sua relação com a mineralogia de solos altamente intemperizados. Scientia Agricola, v. 58, n. 3, p. 627 - 646, 2001. 
FULLER, R.D.; DAVID, M.B.; DRISCOLL, C.T. Sulfate adsorption relationships in forested Spodosols of the Northeastern USA. Soil Science Society of America Journal, v. 49, n.4, p. $1034-1040,1985$.

GALVÃO, T.C.D.; SCHULZE, D.G. Mineralogical properties of collapsible lateritic soil from Minas Gerais, Brazil. Soil Science Society of America Journal, v.60, n.6, p. $1969-1978,1996$.

GEELHOED, J.S.; HIEMSTRA, T.; RIEMSDIJK, W.H. van Phosphate and sulfate adsorption on goethite: single anion and competitive adsorption. Geochimica et Cosmochimica Acta, v.61, n.12, p. 2389 - 2396, 1997.

GILKES, R.J.; HUGHES, J.C. Sodium fluoride pH of south-western Australian soils as an indicator of P-sorption. Australian Journal of Soil Research, v.32, n.4, p. $755-766,1994$.

GILLMAN, G.P. A proposed method for the measurement of exchange properties of high-weathered soils. Australian Journal of Soil Research, v.17, n.1, p.129 $141,1979$.

GILLMAN, G.P. Using variable charge characteristics to understand the exchangeable cation status of oxic soils. Australian Journal of Soil Research, v.22, n. 1, p. $71-80,1984$.

GILLMAN, G.P. Influence of organic matter and phosphate content on the point of zero charge of variable charge components in oxidic soils. Australian Journal of Soil Research, v. 23, n.4, p. $643-646,1985$.

GILLMAN, G.P.; BELL, L.C. Soil solution studies on weathered soils from tropical north Queensland. Australian Journal of Soil Research, v. 16, n. 1, p. $67-77,1978$.

GOLDBERG, S.; SPOSITO, G. A chemical model of phosphate adsorption by soils. I. Reference oxide minerals. Soil Science Society of America Journal, v. 48, n.4, p. $772-778,1984$.

GOLDBERG, S.; LEBRON, I.; SUAREZ, D.L.; HINEDI, Z.R. Surface characterization of amorphous aluminum oxides. Soil Science Society of America Journal, v.65, n.1, p. $78-86,2001$.

GUADALIX, M.E.; PARDO, M.T. Sulphate sorption by variable charge soils. Journal of Soil Science, v. 42, n.4, p. $607-614,1991$. 
HARRISON, R.B.; JOHNSON, D.W.; TODD, D.E. Sulfate adsorption and desorption reversibility in a variety of forest soils. Journal of Environmental Quality, v. 18, n.4, p. $419-426,1989$.

HARTER, R.D. Curve-fit errors in Langmuir adsorption maxima. Soil Science Society of America Journal, v. 48, n.4, p. 749-752, 1984.

HASSET,J.J.; BANWART, W.L.; WOOD, S.G.; MEANSM J.C. Sorption of $\alpha$-naphtahol: Implications corcerning the limits of hydrophobic sorption. Soil Science Society of America Journal, v.45, n.1, p. 38 - 42, 1983.

HENDERSHOT, W.H.; LAVKULICH, L.M.; The use of zero point of charge (ZPC) to assess pedogenic development. Soil Society of America Journal, v. 42, n.3, p. $468-472,1978$.

HENDERSHOT, W.H.; LAVKULICH, L.M. Effect of sodium-chloride saturation and organic-matter removal on the value of zero point of charge. Soil Science, v. 128, n.3, p. $136-141,1979$.

HINGSTON, F.J.; POSNER, A.M.; QUIRK, J.P. Anion adsorption by goethite and gibbsite I. The role of proton in determining adsorption envelope. Journal of Soil Science, v. 23, n.2, p. $177-192,1972$.

HIRD, A.B.; RIMMER, D.L.; LIVENS, F.R. Factors affecting the sorption and fixation of caesium in acid organic soil. European Journal of Soil Research, v. 47, n.1, p. $97-104,1996$.

HOLMGREN, G.G. A rapid citrate-dithionite extractable iron procedure. Soil Science Society of America Proceedings, v.31, n. 2, p.210 - 211, 1967.

HOUNG , K.H.; LEE, D.Y. Comparison of linear and nonlinear Langmuir and Freundlich curve fit in the study of $\mathrm{Cu}, \mathrm{Cd}$ and $\mathrm{Pb}$ adsorption on Taiwan soils. Soil Science, v. 163, n.2, p. $115-121,1998$.

HSU, P.H. Aluminum hydroxides and oxyhydroxides. In: DIXON, J.B. and WEED, S.B. (Ed.). Minerals in soil environments. Madison : Soil Science Society of America, 1989. cap. 7, p.331-378.

HUANG, P.M.; JACKSON, M.L. Mechanism of reaction of neutral fluoride solution with layer silicates and oxides of soils. Soil Science Society of America Proceedings, v. 29, n.5, p.661 - 665, 1965. 
HUETE, A.R.; Mc COLL, J.G. Soil cation leaching by "acid rain" with varying nitrate-tosulfate ratios. Journal of Environmental Quality, v. 13, n. 3, p. 366-371, 1984.

HUGHES, J.C.; BROWN, G.A. A crystallinity index for soil kaolins and its relation to parent rock, climate and soil maturity. Journal of Soil Science, v. 30, n.3, p. $557-563,1979$.

INSKEEP, W.P. Adsorption of sulfate by kaolinite and amorphous iron oxides in the presence of organic ligands. Journal of Environmental Quality, v. 18, n.3, p. 379-385, 1989.

JACKSON, M.L. Soil chemical analysis: advanced course. Madison: University of Wisconsin, 1969. 895p.

JEANROY, E.; RAJOT, J.L. PILLON, P.; HERBILLON, A.J Differential dissolution of hematite and its implication on soil yellowing. Geoderma, v. 50, n.1 e 2, p.79-94, 1991.

JOHNSON, D.W.; TODD, D.E. Relationships among iron, aluminum, carbon and sulfate in a variety of forest soils. Soil Science Society of America Journal, v. 47, n. 4 , p. $792-800,1983$.

JONES, R.C. X-ray diffraction line profile analysis vs. phosphorus sorption by 11 Puerto Rican soils. Soil Science Society of America Journal, v.45, n.4, p.818-825, 1981.

KAISER, K.; ZECK, W. Nitrate, sulfate, and biphosphate retention in acid forest soils affected by natural dissolved organic carbon. Journal of Environmental Quality, v. 25, n.6, p. $1325-1331,1996$.

KÄMPF, N.; SCHWERTMANN, U. The 5M-NaOH concentration treatment for iron oxides in soils. Clays and Clay Minerals, v.30, n.6, p.401-408, 1982.

KÄMPF, N.; CURI, N. Óxidos de ferro: indicadores de ambientes pedogênicos e geoquímicos. Tópicos em Ciência do Solo, v.1, p.107 - 138, 2000.

KÄMPF, N.; SCHWERTMANN, U. Goethitas na interface solo - rocha em amostras do Rio Grande do Sul e Minas Gerais. Revista Brasileira de Ciência do Solo, v. 19, n.3, p.359 - 366, 1995. 
KÄMPF, N.; SCHWERTMANN, U. Avaliação da estimativa de substituição de Fe por Al em hematitas de solos. Revista Brasileira de Ciência do Solo, v.22, n.2, p.209213, 1998.

KÄMPF, N.; RESENDE, M.; CURI, N. Iron oxides in Brazilian Oxisols. In: INTERNATIONAL SOIL CLASSIFICATION WORKSHOP: CLASSIFICATION, CHARACTERIZATION AND UTILIZATION OF OXISOLS, 8., Rio de Janeiro, 1986. Proceedings. Rio de Janeiro: EMBRAPA, SMSS, AID, UPR, 1988. p. $71-77$.

KAMPRATH, E.J.; NELSON, W.L.; FITTS, J.W. The effect of $\mathrm{pH}$, sulfate and phosphate concentrations on the adsorption of sulfate by soils. Soil Science Society of America Proceedings, v. 20, n. 4 , p. 463 - 466, 1956.

KENG, J.C.W.; UEHARA, G. Chemistry, mineralogy and taxonomy of Oxisols and Ultisols. Proceedings of Soil and Crop Sciences Society, v.33, n.1, p.119-126, 1974.

KER, J.C. Mineralogia, sorção e dessorção de fosfato, magnetização e elementos traços de Latossolos do Brasil. Viçosa, 1995. 181p. Tese (Doutorado) Universidade Federal de Viçosa.

KER, J.C.; FONTES, M.P.F.; SOUZA, A.R. de; Resende, M. Adsorção de fósforo em alguns solos latossólicos: relação entre mineralogia e efeito da calagem. Revista Ceres, v. 43, n. 246, p. 216 - 226, 1996.

KINNINBURGH, D.G.; SYERS, J.K.; JACKSON, M.L. Specific adsorption of trace amounts of calcium and strontium by hydrous oxides of iron and aluminum. Soil Science Society of America Proceedings, v.39, n.2, p. $464-470,1975$.

KÜHNEL, R.A.; ROORDA, H.J.; STEENSMA, J.J. The crystallinity of minerals - a new variable in pedogenetic processes: a study of goethites and associated silicates in laterites. Clays and Clay Minerals, v. 23, n.5, p. $349-354,1975$.

LEWIS, D.G.; SCHWERTMANN, U, The influence of Al on iron oxides: Part III. Preparation of Al-goethites in $\mathrm{M} \mathrm{KOH}$. Clay Minerals, v. 14, n.2, p. $115-126$, 1979.

LIU, F.; HE, JISHENG.; COLOMBO,C.; VIOLANTE, A. Competitive adsorption of sulfate and oxalate on goethite in the absence or presence of phosphate. Soil Science, v. 164, n.3, p. $180-189,1999$. 
LUDWIG, B.; KHANNA, P.K.; ANURUGSA, B.; FÖLSTER, H. Assessment of cation and anion exchange and pH buffering in an Amazonian Ultisol. Geoderma, v. 102, n.1, p. $27-40,2001$.

LYNDSAY, W.L. Chemical equilibria in soils. New York: John Wiley, 1979. 449p.

MAES, E.; ISERENTANT, A.; HERBAUTS, J.; DELVAUX, B. Influence of the nature of clay minerals on the fixation of radiocaesium traces in an acid brown earth-podzol weathering sequence. European Journal of Soil Science, v. 50, n.1, p. 117 125, 1999.

MARSH, K.B.; TILLMAN, R.W.; SYERS, J.K. Charge relationships of sulfate sorption by soils. Soil Science Society of America Journal, v. 51, n.2, p. $318-323,1987$.

MARTINEZ, C.E.; KLEINSCHMIDT, A.W.; TABATABAI, M.A. Sulfate adsorption by variable charge soils: effect of low-molecular-weight organic acids. Biology and Fertility of Soils, v. 26, n.3, p. $157-163,1998$.

McBRIDE, M.B. Surface chemistry of soil minerals. In: DIXON, J.B.; WEED, S.B. (Ed.) Minerals in soils environments. Madison: Soil Science Society of America, 1989. cap. 2, p.35 - 88 .

McDONALD, N.W.; HART, J.B. Relating sulfate adsorption to soil properties in Michigan forest soils. Soil Science Society of America Journal, v. 54, n.1, p. $238-245,1990$.

MEAD, J.A. A comparison of the Langmuir, Freundlich and Temkin equations to describe phosphate adsorption properties of soils. Australian Journal of Soil Research, v. 19, n.4, p. 333-342, 1981.

MEHRA, O.P.; JACKSON, M.L. Iron oxide removal from soils and clays by a dithionitecitrate system buffered with sodium bicarbonate. Clays and Clay Minerals, v.7, n.3, p. $317-327,1960$.

MEIJER, E.L.; BUURMAN, P. Salt effect in a multicomponent variable charge system: curve of zero salt effect, registered in a pH - stat. Journal of Soil Science, v.38, n.2, p. $239-244,1987$.

MEKARU, T.; UEHARA, G. Anion adsorption in ferruginous tropical soils. Soil Science Society of America Proceedings, v. 36, n.2, p. 296-300, 1972. 
MESQUITA FILHO, M.V.; TORRENT, J. Phosphate sorption as related to mineralogy of a hydrosequence of soils from the Cerrado region (Brazil). Geoderma, v.58, n 1, p. 107-123, 1993.

MESTDAGH, M.M.; VIELVOYE, L.; HERBILLON, A.J. Iron in kaolinite : II. The relationship between kaolinite crystallinity and iron content. Clay Minerals, v. 15, n.1. p. $1-13,1980$.

MONIZ, A.C. Elementos de pedologia. Rio de Janeiro: Livros Técnicos e Científicos, 1975. 460p.

MOTAVALLI, P.P.; DUXBURY, J.M.; SOUZA, D.M.G. The influence of organic soil amendments on sulfate adsorption and sulfur availability in a Brazilian Oxisol. Plant and Soil, v. 154, n.2, p. $301-308,1993$.

MOTTA, P.E.F da.; KÄMPF, N. Iron oxides properties as support to soil morphological features for prediction of moisture regimes in Oxisols of Central Brazil. Zeitschrift fur Pflanzenernährung Bodenkunde. v. 26, n.5-6, p. 321 - 326, 1983.

MURPHY, J., RILEY, J.P. A modified single solution method for determination of phosphate in natural waters. Analytica Chimica Acta, v.27, n.1, p. 31-36, 1962.

NASCIMENTO, R.A.M., CUNHA, L.H.; RAMOS, D.P. Comparações entre o ponto de carga zero (titulação potenciométrica), mineralogia e diversos outros parâmetros para quatorze perfis de Latossolos. In: REUNIÃO DE CLASSIFICAÇÃO E CORRELAÇÃO DE SOLOS E INTERPRETAÇÃO DE APTIDÃO AGRÍCOLA, 3., Rio de Janeiro, 1988. Anais. Rio de Janeiro: EMBRAPA, SNLCS, 1988. p. $365-$ 390.

NETTO, A.R. Influência da mineralogia da fração argila sobre propriedades físicoquímicas de solos brasileiros. Viçosa, 1996. 144p. Dissertação (Mestrado) Universidade Federal de Viçosa.

NORRISH, K.; TAYLOR, R.M. The isomorphous replacement of iron by aluminium in soil goethites. Journal of Soil Science, v.12, n.2, p.294-304, 1961.

OLIVEIRA, J.B. de; JACOMINE, P.K.T.; CAMARGO, M.N. Classes gerais de solos do Brasil: guia auxiliar para seu reconhecimento. 2.ed. Jaboticabal: FUNEP, 1992. 201p. 
OLSEN, S.R.; WATANABE, F.S. A method to determine a phosphorus adsorption maximum of soils as measured by Langmuir isotherm. Soil Science Society of America Proceedings, v. 21, n.1, p. $144-149,1957$.

OWUSU-BENNOAH, E.; SZILAS, C.; HANSEN, H.C.B.; BORGGAARD, O.K. Phosphate sorption in relation to aluminum and iron oxides of Oxisols from Ghana. Communications in Soil Science and Plant Analysis, v. 28, n.9/10, p. 685 697, 1997.

PARFITT, R.L. Anion adsorption by soils and soil materials. Advances in Agronomy, v. 30 , p. $1-50,1978$.

PARFITT, R.L.; CHILDS, C.W. Estimation of forms of Fe and Al: A review, and analysis of contrasting soils by dissolution and Mössbauer methods. Australian Journal of Soil Research, v.26, n.1, 121 - 144, 1988.

PARFITT, R.L.; SMART, R.S.C. The mechanism of sulfate adsorption on iron oxides. Soil Science Society of America Journal, v. 42, n.1, p. 48 - 50, 1978.

PARKER, J.C.; ZELAZNY, L.W.; SAMPATH, S.; HARRIS, W.G. A critical evaluation of the extension of zero point of charge (ZPC). Theory to soil systems. Soil Science Society of America Journal, v. 43, n.4, p. 668 - 673, 1979.

PARKS; G.A. The isoelectric points of solid oxides, solid hydroxides, and aqueous hydroxo complex systems. Chemical Reviews, v. 65, n.2, p. $177-198,1965$.

PATIL, S.G.; SARMA, V.A.K.; VAN LOON, G.W. Acid rain, cation dissolution, and sulphate retention in three tropical soils. Journal of Soil Science, v. 40, n.1, p. $85-93,1989$.

PAVAN, M.A.; BINGHAM, F.T.; PRATT, P.F. Redistribution of exchangeable calcium, magnesium, and aluminum following lime or gypsum applications to a Brazilian Oxisol. Soil Science Society of America Journal, v. 48, n.1, p. 33 -38, 1984.

PEAK, J.D.; FORD, R.G.; SPARKS, D.L. An in situ ATR-FTIR investigation of sulfate bonding mechanisms on goethite. Journal of Colloid and Interface Science, v. 47 , n.1, p. $289-299,1999$.

PERROTT, K.W.; SMITH, B.F.L.; INKSON, R.H.E. The reaction of fluoride with soils and soil minerals. Journal of Soil Science, v 27, n.1, p. 58- 67, 1976a. 
PERROTT, K.W.; SMITH, B.F.L.; MITCHELL, B. D. Effect of pH on the reaction of sodium fluoride with hydrous oxides of silicon, aluminium, and iron, and with poorly ordered aluminosilicates. Journal of Soil Science, v.27, n.3, p. 348-356, 1976b.

PÖTTER, R.O.; KÄMPF, N. Argilo-minerais e óxidos de ferro em Cambissolos e Latossolos sob regime climático térmico údico no Rio Grande do Sul. Revista Brasileira de Ciência do Solo, v.5, n.3, p. 153 - 159, 1981.

PRASETYO, B.H.; GILKES, R.J. Properties of iron oxides from red soils derived from volcanic tuff in West Java. Australian Journal of Soil Research, v. 32, n. 4, p. $781-794,1994$.

QAFOKU, N.P.; SUMNER, M.E. Retention and transport of calcium nitrate in variable charge subsoils. Soil Science, v. 166, n.5 , p. 297 - 307, 2001.

QUAGGIO, J.A.; DECHEN, A.R.; RAIJ, B. van. Efeitos da aplicação de calcário e gesso sobre a produção de amendoim e lixiviação de base no solo. Revista Brasileira de Ciência do Solo, v. 6, n.3, p. 189 - 194, 1982.

QUANG, V.D.; THAI, V.C.; LINH, T.T.T.; DUFEY, J.E. Phosphorus sorption in soils of the Mekong Delta (Vietnam) as described by the binary Langmuir equation. European Journal of Soil Science, v. 47, n.1, p. 113 - 123, 1996.

RAIJ, B. van Gesso agrícola na melhoria do ambiente radicular no subsolo. São Paulo: ANDA, 1988. 88p.

RAIJ, B. van; PEECH, M. Electrochemical properties of some Oxisols and Alfisols of the tropics. Soil Science Society of America Proceedings, v.36, n.4, p.587 593, 1972.

RAIJ, B. van; QUAGGIO, J.A. Determinação de fósforo, cálcio, magnésio e potássio extraídos com resina trocadora de íons. In RAIJ, B. van; ANDRADE, J.C. de; CANTARELLA, H.; QUAGGIO, J.A. (Ed.) Análise química para avaliação da fertilidade de solos tropicais. Campinas : Instituto Agronômico, 2001. cap. 11, p.189- 199 .

RAIJ, B. van.; CANTARELLA, H.; QUAGGIO, J.A.; FURLANI, A.M.C. Recomendações de adubação e calagem para o Estado de São Paulo: 2.ed. Campinas: Instituto Agronômico, 1996. 285p. 
RAJAN, S.S.S. Sulfate adsorption on hydrous alumina ligands displaced and changes in surface charge. Soil Science Society of America Journal, v. 42, n.1, p. 39 44, 1978.

RANST, E. van.; SHAMSHUDDIN, J.; BAERT, G.; DZWOWA, P.K. Charge characteristics in relation to free iron and organic matter of soils from Bambouto Mountains, Western Cameroon. European Journal of Soil Science, v. 49, n.2, p. $243-252,1998$.

RAO, S.M.; SRIDHARAN, A. Mechanism of sulfate adsorption by kaolinite. Clays and clay minerals, v. 32, n. 5 , p. 414-418, 1984.

RASIAH, V.; ARMOUR, J.D. Nitrate accumulation under cropping in the Ferrosols of far north Queensland wet tropics. Australian Journal of Soil Research, v. 39, n.2, p. $329-341,2001$.

RAVEN, K.P.; HOSSNER, L.R. Soil phosphorus desorption kinetics and its relationship with plant growth. Soil Science Society of America Journal, v. 58, n.2, p. 419-423, 1994.

RESENDE, M.; SANTANA, D.P. Uso das relações Ki e Kr na estimativa da mineralogia para a classificação dos Latossolos. In: REUNIÃO DE CLASSIFICAÇÃO, CORRELAÇÃO DE SOLOS E INTERPRETAÇÃO DE APTIDÃO AGRÍCOLA, 3., Rio de Janeiro, 1988. Anais. Rio de Janeiro: EMBRAPA, SNLCS, SECS, 1988. p. 225-232.

RESENDE, M.; BAHIA FILHO, A.F.C.; BRAGA, J.M. Mineralogia da fração argila de Latossolos estimada por alocação a partir do teor total de óxidos do ataque sulfúrico. Revista Brasileira de Ciência do Solo, v.11, n.1, p.17-23, 1987.

RESENDE, M.; CURI, N.; REZENDE, S.B.; CORRÊA, G.F. Pedologia: base para a distinção de ambientes. Viçosa : NEPUT, 1985. 304p.

RHOADES, J.D.; INGVALSON, R.D.; HATCHER, J.T. Laboratory determination of leaching soil boron. Soil Science Society of America Proceedings, v.34, n.6, p.871-875, 1970.

RIBEIRO, E.S.; DIAS, L.E.; ALVAREZ V., V.H.; MELLO, J.W.V.; DANIELS, W.L. Dynamics of sulfur fractions in Brazilian soils submitted to consecutive harvests of sorghum. Soil Science of America Journal, v.65, n.3, p. 787- 794, 2001. 
RIETRA, R.P.J.J.; HIEMSTRA, T.; RIEMSDIJK, W.H. van Sulfate adsorption on goethite. Journal of Colloid and Interface Science, v. 218, n.2, p. $511-521$, 1999.

RUSSEL, J.D.; PARFITT, R.L.; FRASER, A.R.; FARMER.V.C.; Surface structure of gibbsite, goethite and phosphated goethite. Nature, v. 248, n.5445, p. $220-221$, 1974.

SAKURAI, K.; NAKAYAMA, A.; WATANABE, T.; KYUMA, K. Influence of aluminum ion on the determination of zpc (zero point of charge) of variable charge soils. Soil Science and Plant Nutrition, v. 35, n.4, p. 623-633, 1989a.

SAKURAI, K.; OHDATE, Y.; KYUMA, K. Factors affecting zero point of charge (zpc) of variable charge soils. Soil Science and Pant Nutrition, v.35, n.1 p. $21-31$, 1989b.

SAS INSTITUTE. SAS: principles of regression analysis - course notes. Cary, 1994. $655 p$.

SCHULZE, D. G.; SCHWERTMANN, U. The influence of aluminum on iron oxides: X. Properties of Al - substituted goethites. Clay Minerals, v.19, n.4, p. 521 - 539, 1984.

SCHULZE, D.G. The influence of aluminum on iron oxides. VIII. Unit-cell dimensions of Al-substituted goethites and estimation of Al from them. Clays and Clay Minerals, v.32, n.1, p.36-44, 1984.

SCHWERTMANN, $U$ The influence of aluminium on iron oxides: IX. Dissolution of Algoethites in $6 \mathrm{M} \mathrm{HCl}$. Clay Minerals, v. 19, n.1, p. 9-19, 1984.

SCHWERTMANN, U. The effect of pedogenic environments on iron oxide minerals. Advances in Soil Science, v.1, p.171-200, 1985.

SCHWERTMANN, U. Solubility and dissolution of iron oxides. Plant and Soil, v. 130, n. 1 e 2, p. $1-25,1991$. 
SCHWERTMANN, U.; CARLSON, L. Aluminum influence on iron oxides: XVII. Unit-cell parameters and aluminum substitution of natural goethites. Soil Science Society of America Journal, v. 58, n. 1, p. 256-261, 1994.

SCHWERTMANN, U.; FECHTER, $\mathrm{H}$. The point of zero charge of natural and synthetic ferrihydrites and its relation to adsorbed silicate. Clay Minerals, v. 17, n.4, p. $471-476,1982$.

SCHWERTMANN, U.; FECHTER, H. The influence of aluminium on iron oxides: XI. Aluminum-substituted maghemite in soils and its formation. Soil Science Society of America Journal, v. 48, n.6, p. $1462-1463,1984$.

SCHWERTMANN, U.; FITZPATRICK, R.W. Iron minerals in surface environments. In: SKINNER, H.C.W.; FITZPATRICK, R.W. (Ed.) Biomineralization: processes of iron and manganese - modern and ancient environments. Catena Supplement, v. 21, n.1, p. $7-30,1992$.

SCHWERTMANN, U.; HERBILLON, AJ. Some aspects of fertility associated with te mineralogy of highly weathered tropical soils. In: LAL, R.; SANCHES, P.A. (Ed.). Myths and science of soils of the tropics. Madison: Soil Science Society of America, 1992, cap.2, p. 47-59.

SCHWERTMANN, U.; KÄMPF, N. Óxidos de ferro jovens em ambientes pedogenéticos brasileiros. Revista Brasileira de Ciência do Solo, v.7, n.3, p. $251-255,1983$.

SCHWERTMANN, U.; KÄMPF, N. Properties of goethite and hematite in kaolinitic soils of southern and central Brazil. Soil Science, v. 139, n.4, p. 344-350, 1985.

SCHWERTMANN, U.; LATHAM, M. Properties of iron oxides in some New Caledonian oxisols. Geoderma, v.39, n.2, p.105-123, 1986.

SCHWERTMANN, U.; TAYLOR, R.M. Iron oxides. In: DIXON, J.B.; WEED, S.B. (Ed.) Minerals in soils environments. Madison: Soil Science Society of America, 1989. cap. 8 , p. $379-438$.

SCHWERTMANN, U.; FITZPATRICK, R.W.; TAYLOR, R.M.; LEWIS, D.G. The influence of aluminum on iron oxides Part II. Preparation and properties of Alsubstituted hematites. Clays and Clay Minerals, v.27, n.2, p.105-112, 1979. 
SCOTT, H.D.; BEASLEY, S.D.; THOMPSON. L.F. Effect of lime on boron transport to and uptake by cotton. Soil Science Society of America Proceedings, v.39, n.7, p.1116 -1121, 1975.

SERRANO, E.R.; ARAIAS, J.S.; FERNÁNDEZ, P.G. Soil properties that affect sulphate adsorption by palexerults in western and central Spain. Communications in Soil Science and Plant Analysis, v. 30, n. 9 e 10, p. 1521 - 1530, 1999.

SILVA, M. L. N.; CURI, N.; MARQUES, J.J.G.S.M.; GUILHERME, L.R.; LIMA, J.M. Ponto de efeito salino nulo e suas relações com propriedades mineralógicas e químicas de Latossolos brasileiros. Pesquisa Agropecuária Brasileira, v. 31, n. 9 , p. $663-671,1996$.

SINGH, B.; GILKES, R.J. Phosphorus sorption in relation to soil properties for the major soil types of South-western Australia. Australian Journal of Soil Research, v. 29, n. 5, p. 603-618, 1991.

SINGH, B.; GILKES, R.J. Properties and distribution of iron oxides and their association with minor elements in the soils of south-western Australia. Journal of Soil Science, v.43, n.1, p. 77-98, 1992a.

SINGH, B.; GILKES, R.J. Properties of soil kaolinites from south-western Australia. Journal of Soil Science, v. 43, n.4, p. $645-667,1992 b$.

SINGH, B.R. Sulfate sorption by forest soils; 2. Sulfate adsorption isotherms and comparison of different sorption equation in describing sulfate adsorption. Soil Science, v.138, n.3, p.189-197, 1984.

SINGH, B.R.; ABRHAMSEN, G.; STUANES, A. Effects of simulated acid rain on sulfate movement in acid forest soils. Soil Science Society of America Journal, v. 44 , n.1, p. $75-80,1980$.

SINGH, U.; UEHARA, G. Electrochemistry of the double layer: principles and applications to soils. In: SPARKS, D.L. (Ed.) Soil physical chemistry. Boca Raton: CRC Press, 1999. cap. 1, p.1-46.

SIQUEIRA, C.; LEAL, J.R.; VELLOSO, A.C.X.; SANTOS, G.A. Eletroquímica de solos tropicais de carga variável: II. Quantificação do efeito da matéria orgânica sobre o ponto de carga zero. Revista Brasileira de Ciência do Solo, v. 14, n.1, p. 13 $17,1990$. 
SPARKS, D.L. Environmental soil chemistry. San Diego: Academic Press, 1995.265p.

SPARKS, D.L.; JARDINE, P.M. Comparison of kinetic equations to describe potassium-calcium exchange in pure and mixed systems. Soil Science, v. 135, n.2, p. 115-122, 1984.

SPOSITO, G. Derivation of the Langmuir equation for ion exchange reactions in soils. Soil Science Society of America Journal, v. 43, n.1, p. 197 - 198, 1979.

SPOSITO, G. Derivation of the Freundlich equation for ion exchange reactions in soils. Soil Science Society of America Journal, v. 44, n.3, p. 652 - 654, 1980.

SPOSITO, G. The chemistry of soils. New York, Oxford University Press, 1989. $277 \mathrm{p}$.

STRAUSS, R.; BRUMMER, G.W.; BARROW, N.J. Effects of crystallinity of goethite. II. Rates of sorption and desorption of phosphate. European Journal of Soil Science, v. 48, n.1, p. $101-104,1997$.

STUMM, W.; MORGAN, J.J. Aquatic chemistry. New York Wiley-Interscience, 1981. 780p.

SUN, X.; DONER, H.E. An investigating of arsenate and arsenite bonding structures on goethite by FTIR. Soil Science, v. 161, n.2 , p. 865 - 872, 1996.

SWEEGERS, C.; ENCKEVORT, W.J.P van.; MEEKES, H.; BENNEMA, P.; HIRALAL, I.D.K.; RIJKEBOER, A. The impact of twinning on the morphology of $\gamma-\mathrm{Al}(\mathrm{OH})_{3}$ crystals. Journal of Crystal Growth, v. 197, n.1-2, p. 244 - 253, 1999.

TABATABAI, M.A. Sulfur. In: PAYNE, A.L.; FRENEY, J.R.; MILLER, R.H.; (Ed.) Methods of soil analysis. Part 2 - Chemical and microbiological properties. 2. ed. Madison : Soil Science Society of America; American Society of Agronomy, 1982. cap. 28, p. $501-538$.

TAYLOR, R.W.; BLEMA, W.F.; TU, S.I. On the Langmuir phosphate adsorption maximum. Communications in Soil Science and Plant Analysis, v. 27, n.13-14, p. 2713, 2722, 1996.

TOMA, M.; SUMNER, M.E.; WEEKS, G.; SAIGUSA, M. Long term effects of gypsum on crop yield and subsoil chemical properties. Soil Science Society of America Journal, v. 39, n.4, p.891 - 895, 1999. 
TORRENT, J.; CABEDO, A. Sources of iron oxides in Reddish Brown soil profiles from calcarenites in southern Spain. Geoderma, v.37, n.1, p. 57 - 66, 1986.

TORRENT, J.; BARRÓN, V.; SCHWERTMANN, U. Phosphate adsorption by goethites differing in crystal morphology. Soil Science Society of America Journal, v, 54, n.4, p. $1007-1012,1990$.

TORRENT, J.; BARRÓN, V.; SCHWERTMANN, U. Fast and slow phosphate sorption by goethite-rich natural materials. Clays and Clay Minerals, v.40, n.2, p. $14-21$, 1992.

TORRENT, J.; SCHWERTMANN, U.; BARRÓN, V. The reductive dissolution of synthetic goethite and hematite in dithionite. Clay Minerals, v. 22, n.3, p. 329 337, 1987.

TROLARD, F.; TARDY, Y. The stabilities of gibbsite, boehmite, aluminous goethite and aluminous hematite in bauxites, ferricretes and laterites $\approx$ a function of water activity, temperature and particle size. Geochimica et Cosmochimica Acta, v. 51, n.4, p. $945-957,1987$.

TURNER, L.J.; KRAMER, J.R. Sulfate binding on goethite and hematite. Soil Science, v. 152, n.3, p. $226-230,1991$.

TURNER, L.J.; KRAMER, J.R. Irreversibility of sulfate sorption on goethite and hematite. Water, Air and Soil Pollution, v. 63, n.1-2, p. 23-32, 1992.

UDO, E.J.; UZU, F.O. Characteristics of phosphorus adsorption by some Nigerian soils. Soil Science Society of America Proceedings, v. 36, n.6, p. $879-883$, 1972.

WANG, H.L., HEDLEY, M.J.; BOLN, N.S.; HORNE, D.J. The influence of surface incorporated lime and gypsiferous by-products on surface and subsurface soil acidity. I. Soil solution chemistry. Australian Journal of Soil Research, v. 37, n.1, p. $165-180,1999$.

WEBER, O.L.S. Cargas elétricas de superfície e seletividade catiônica de solos com carga variável medidas pelo método de adsorção de césio. Piracicaba, 2000.156p. Tese (Doutorado) - Escola Superior de Agricultura "Luiz de Queiroz", Universidade de São Paulo. 
WONG, M.T.F.; HUGHES, R.; ROWELL, D.L. Retarded leaching of nitrate in acid soils from the tropics: measurement of effective anion exchange capacity. Journal of Soil Science, v. 41, n.4, p. $655-663,1990$.

XUE, S.K.; SELIM, H.M. Modeling adsorption-desorption kinetics of alachlor in a Typic Fragiudalf. Journal of Environmental Quality, v.24, n.5, p. 896 - 903, 1995.

YAPP, C. J. Effects of AIOOH - FeOOH solid solution on goethite-hematite equilibrium. Clays and Clay Minerals, v.31, n.3, p. $239-240,1983$.

ZELAZNY, L.W.; HE, L.; VANWORMHOUDT, A. Charge analysis of soils and anion exchange. In: SPARKS, D.L. (Ed.). Methods of soil analysis. Part 3 - Chemical methods. Madison : Soil Science Society of America; American Society of Agronomy, 1996. cap. 41, p.1231-1253.

ZHANG, G.Y.; YU, T.R. Coordination adsorption of anions. In YU, T.R (Ed.) Chemistry of variable charge soils. New York: Oxford University Press, 1997. cap. 6, p. $175-218$.

ZHANG,P.C.; SPARKS, D.L. Kinetics and mechanisms of sulfate adsorption/desorption on goethite using pressure-jump relaxation. Soil Science Society of America Journal, v. 54, n.5, p. $1266-1273,1990$.

ZHANG, X.N.; ZHAO, A.Z. Surface charge. In YU, T.R (Ed.) Chemistry of variable charge soils. New York: Oxford University Press, 1997. cap. 2, p. 17 -63.

ZHANG, X.N.; ZHANG, G.Y.; ZHAO, A.Z.; YU, T.R. Surface electrochemical properties of the B horizon of a Rhodic Ferralsol, China. Geode rma, v.44, n.4, p. $275-286$, 1989. 